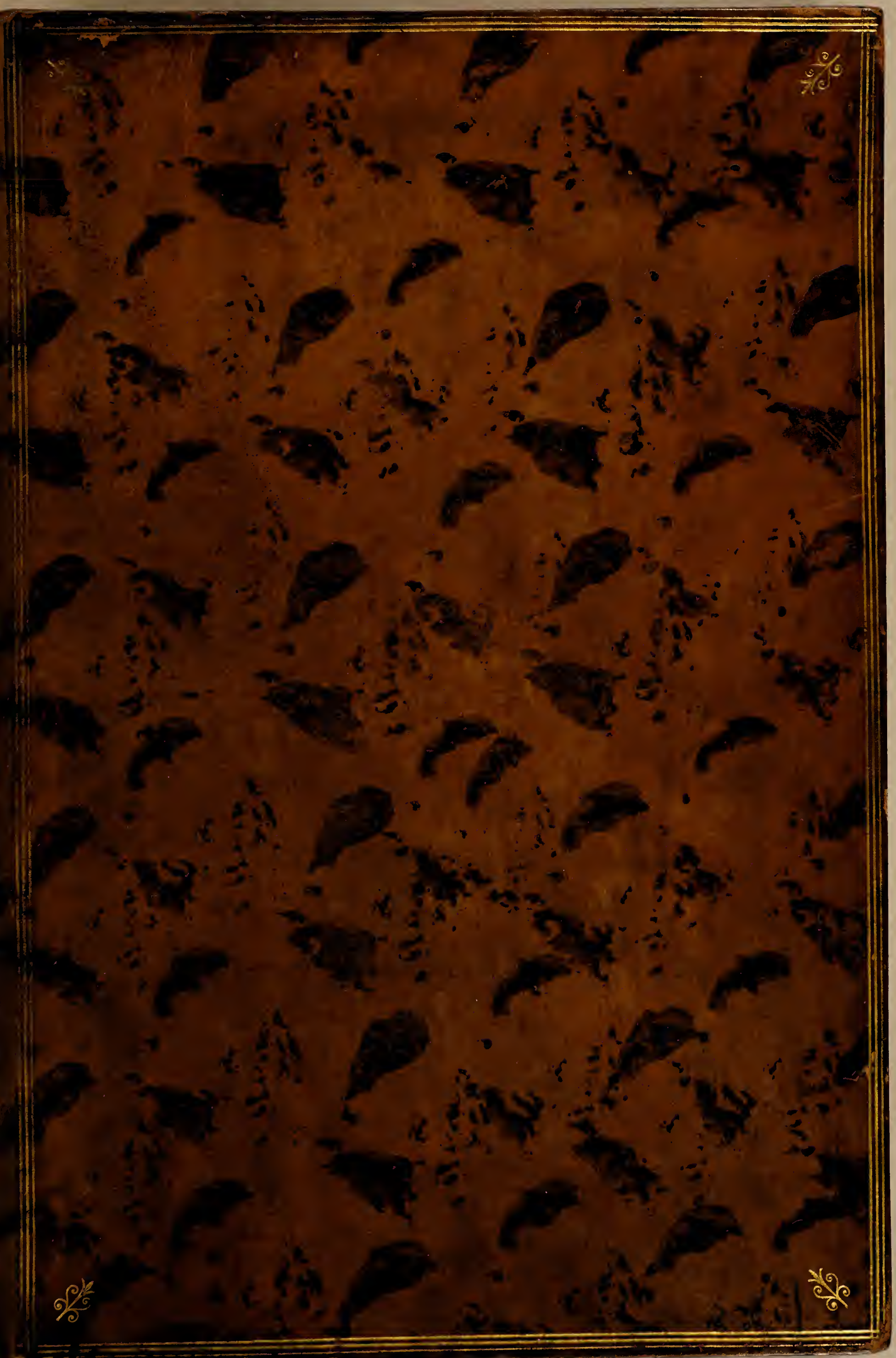




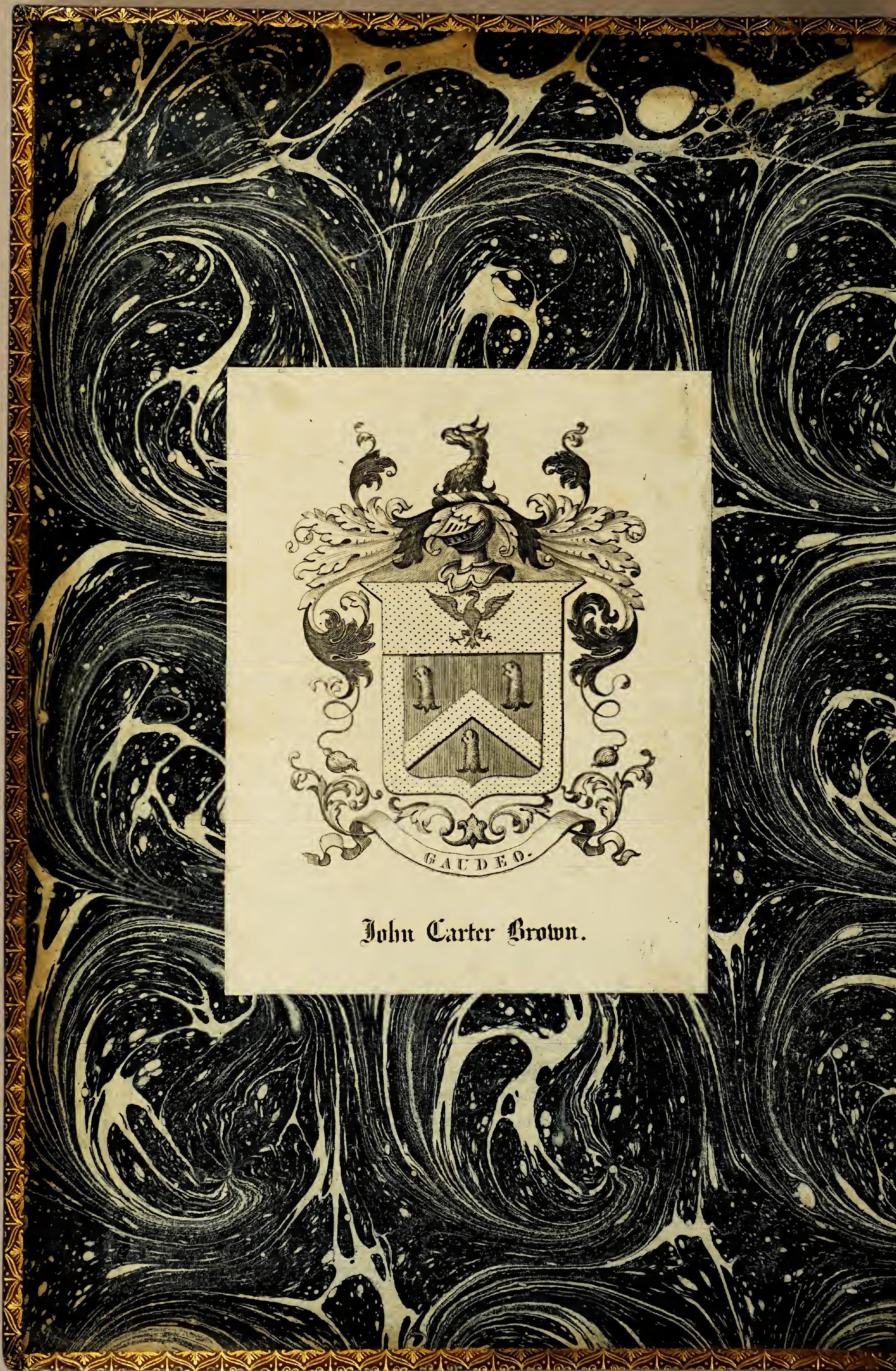




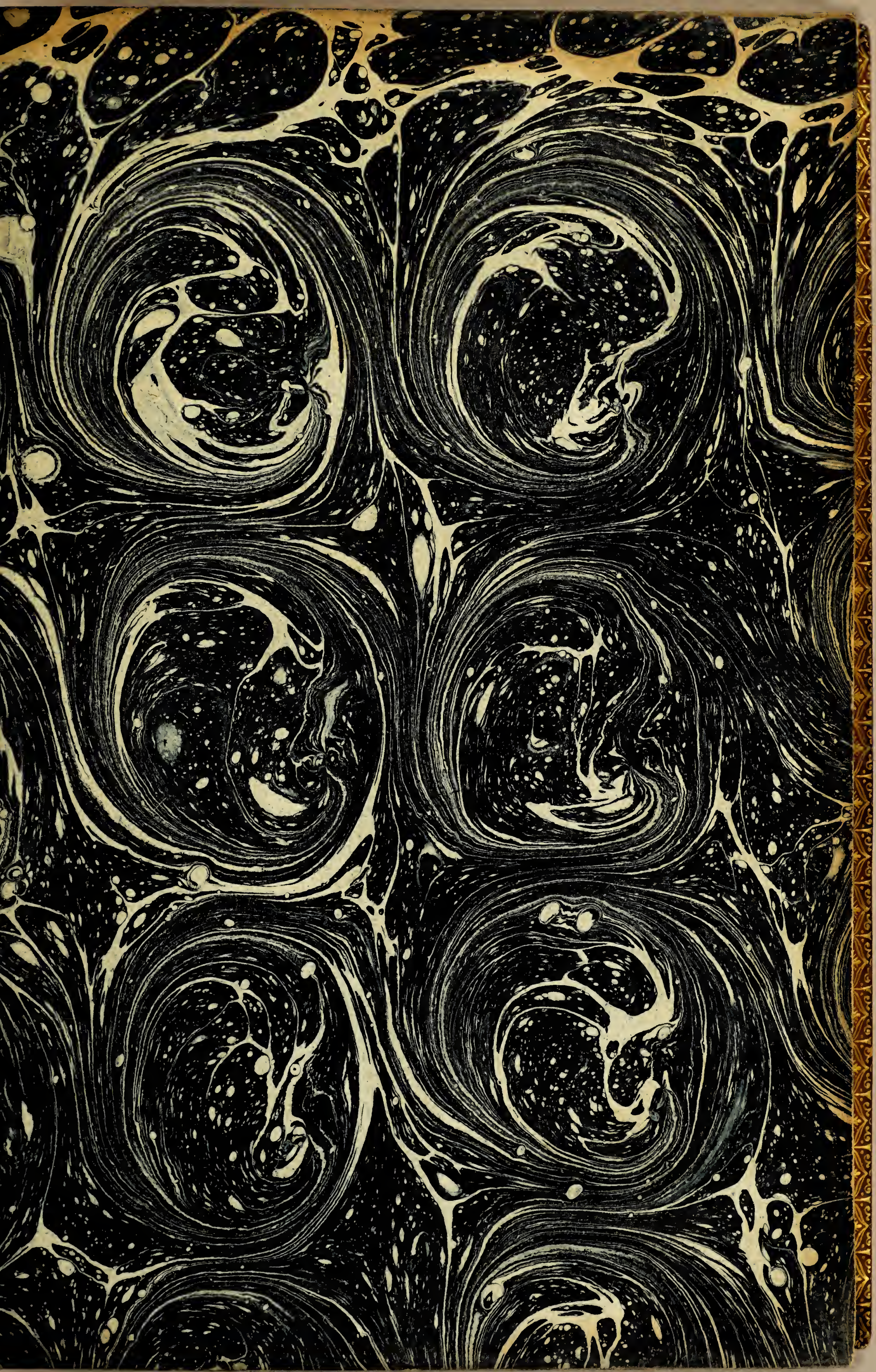







\section{NOTICIAS AMERICANAS:}

\section{ENTRETENIMIENTOS FÍSICO-HISTÓRICOS}

SOBRE

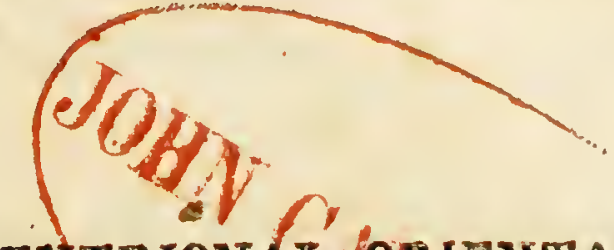

IA AMERICA MERIDIONAI, Y LA SETTENTRIONALIGHENTAL:

COMPARACION GENERAL

DE LOS TERRITORIOS, CLIMAS Y PRODECCIONES

EN LAS TRES ESPECIES

\section{VEGETAL, ANIMAL Y MINERAL;}

CON UNA RELACION PARTICULAR

DE IOS INDIOS DE ARUELLOS PAISES, SUS COSTUMBRES

$Y$ USOS, DE LAS PETRIFICACIONES DE CUERPOS

MARINOS, Y DE LAS ANTIGÜEDADES.

Con un discurso sobre el idioma, y conjeturas sobre el modo con que pasáron los primeros pobladores.

\section{SU AUTOR}

El Exc. Sr. Don Antonio de Ulloa, Comendador de Ocana en la - Orden de Santiago; Teniente Goneral de la Real Armada; de la Real

Sociedad de Lóndres, y de las Reales Academias de las Ciencias de Stockolmo, Bẹlin, E'c.

CON LICENCIA.

MADRID EN LA IMPRENTA REALE

AÑO I 792. 



\section{INTRODUCCION.}

FI deseo de hacer comunicables las noticias de las Indias ha sido el objeto de esta obra, fundándose en la escasez de Autores que traten de lo mucho que encierran aquellos dilatados territorios; pues á correspondencia de su extension ministran materia sobre que hacerlo abundantemente. No ha sido el intento formar una descripcion general y completa que lo abrace todo, porque á tanto empeño sería necesario componer una obra que correspondiese á lo vasto del objeto, y haberlos exâminado enteramente con este fin en sus largas distancias, cuyo asunto pide la vida de varios que se ocupasen en formar memorias de las particularidades que fuesen encontrando. Esta se reduce á las noticias generales que sirven para el conocimiento de aquella parte de mundo, y de la Física natural, con las correspondientes á lo que se registra en ellas de mas particular; siendo esto lo que parece mas conforme al intento y á la comprehension de las raras producciones de la naturaleza. Estos asuntos han merecido en todos los tiempos la aplicacion de los hombres, tomando por principios fundamentales de sus luces el estudio de aquella sabia maestra, y la comparacion de sus obras con otras, pues en ellas se encuentra quanto hay de raro y admirable en el mundo, hasta los términos á donde puede llegar la comprehension humana. * 2

Los 
rio, sin conocer ellos la cansa primera que le co. munica la virtud para que sea abundante, y no detienen la consideracion sobre las propiedades, los efectos, y lo raro de las cosas en sí, porque no llegan á tocar con el entendimiento el mérito que encierran, y la diferencia que hay de lo uno á lo otro. Las gentes mas sabias son asimismo las mas cultas; cuya ventaja adquieren por medio de la instruccion, siendo sus rudimentos el estudio que hacen del mundo for sus partes. A medida que se alejan mas de estas luces, se acercan á la ignorancia hasta degenerar en la barbarie. Pero si se mira la vida como puramente rústica, no es necesario mas conocimiento que el que corresponde al instinto de la irracionalidad; y así lo acredita, no só́o lo que sucede con los Indios, que fermanecen en su primitivo estado, sino tambien con distintos pueblos Europeos, hácia lo mas retirado del Norte, del Asia, y del Africa, en algunas partes, que discrepan poco entre sí, con la diferencia en que los de las Indias, hasta el término en que entráron los Españoles, eran quasi todos bárbaros, apartándose poco de esta esfera con los escasos rudimentos que adquirieron por medio de los Soberanos que con mas luces que el resto pudiéron levantarse con la soberanía; y que en las otras partes hubo naciones y pueblos cultos, que siempre se diferenciaban de los que, subsistiendo en el primitivo estado, vivian en la mayor tosquedad; y aun todavía fiay bastantes en estas partes civilizadas, que no conocen mas reglas 


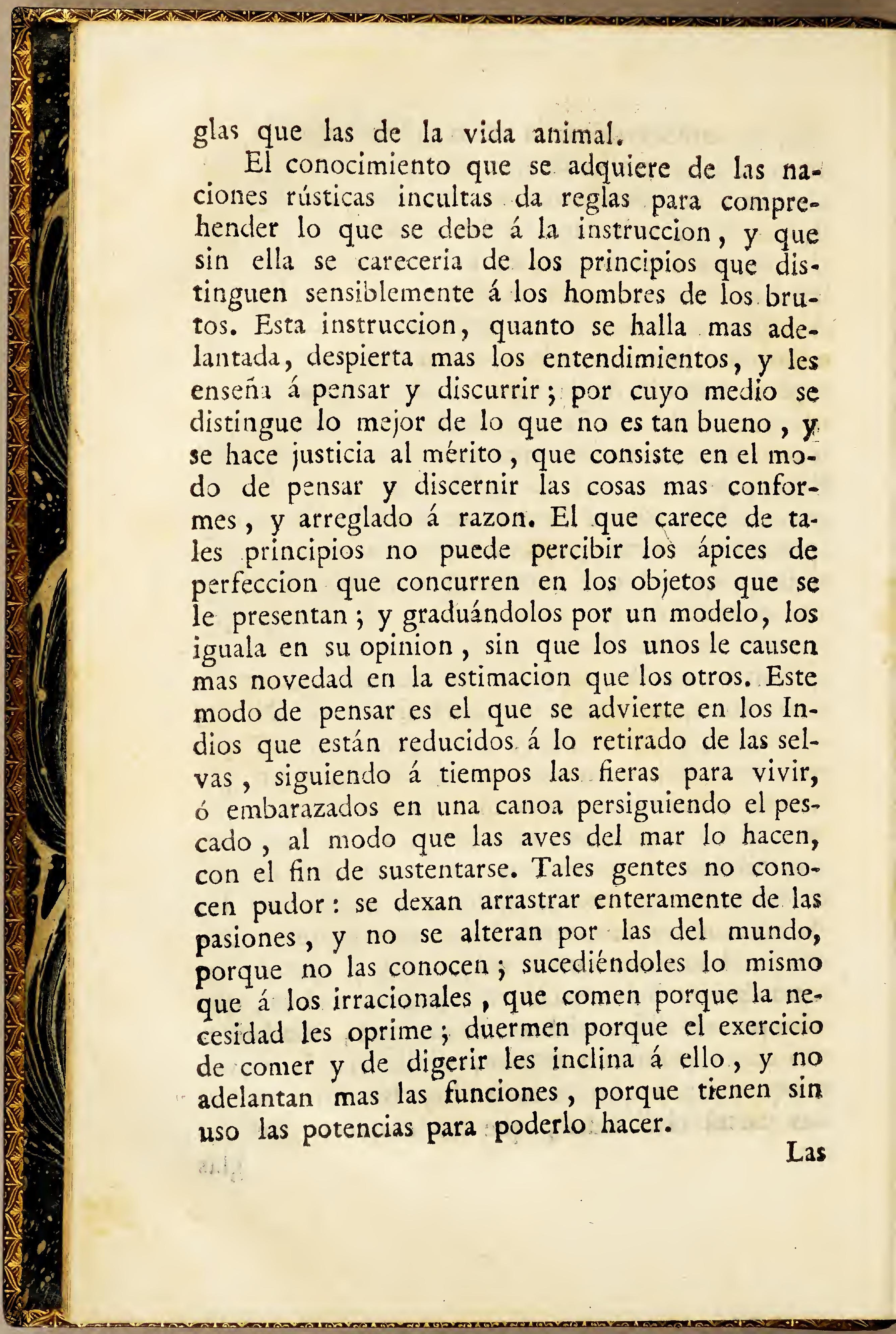


Las noticias del mundo, y de lo que contiene en sí, no se adquieren sin el de las partes que lo componen, pues una sola no da idea de lo que encierra en todo el resto. Este desvelo es el que adelanta las gentes al término de elevarse sobre los que saben ménos, y por grados va subiendo de punto desde lo ínfimo hasta los términos mas altos á donde puede llegar la comprehension. Los que mas se aplican á ello son los que consiguen la superioridad, mediante las luces que el entendimiento les ministra para hallar los recursos que no pueden conseguir los limitados. Si los Indios hubiesen sido igualmente instruidos que los Españoles, no hubieran sido sojuzgados con tanta facilidad, ni se les hubiera hecho extraño ver gentes blancas, y con barbas, ni otras muchas cosas que les sorprenhendiéron. Esta comparacion es como de lo máxîmo á lo mínimo, entre cuyos términos caben otros muchísimos, y en todos ellos es principio seguro, que el que tiene la superioridad en las luces del entendimiento, la tiene igualmente en el modo de pensar y discurrir con sujecion á la razon.

Despues del descubrimiento de las Indias no se ha trabajado con la aplicacion que se requeria en conocer lo que encierran de raro, haciendo poco aprecio de esta parte, como ménos apetecible, siendo pocos los que han paradó la considercion en ella, fuera de aquellas primeras noticias que se adquiriéron en los tiempos inmediatos á la conquista: no se han repetido, ni se han hecho especulaciones para adelantarlas; por 


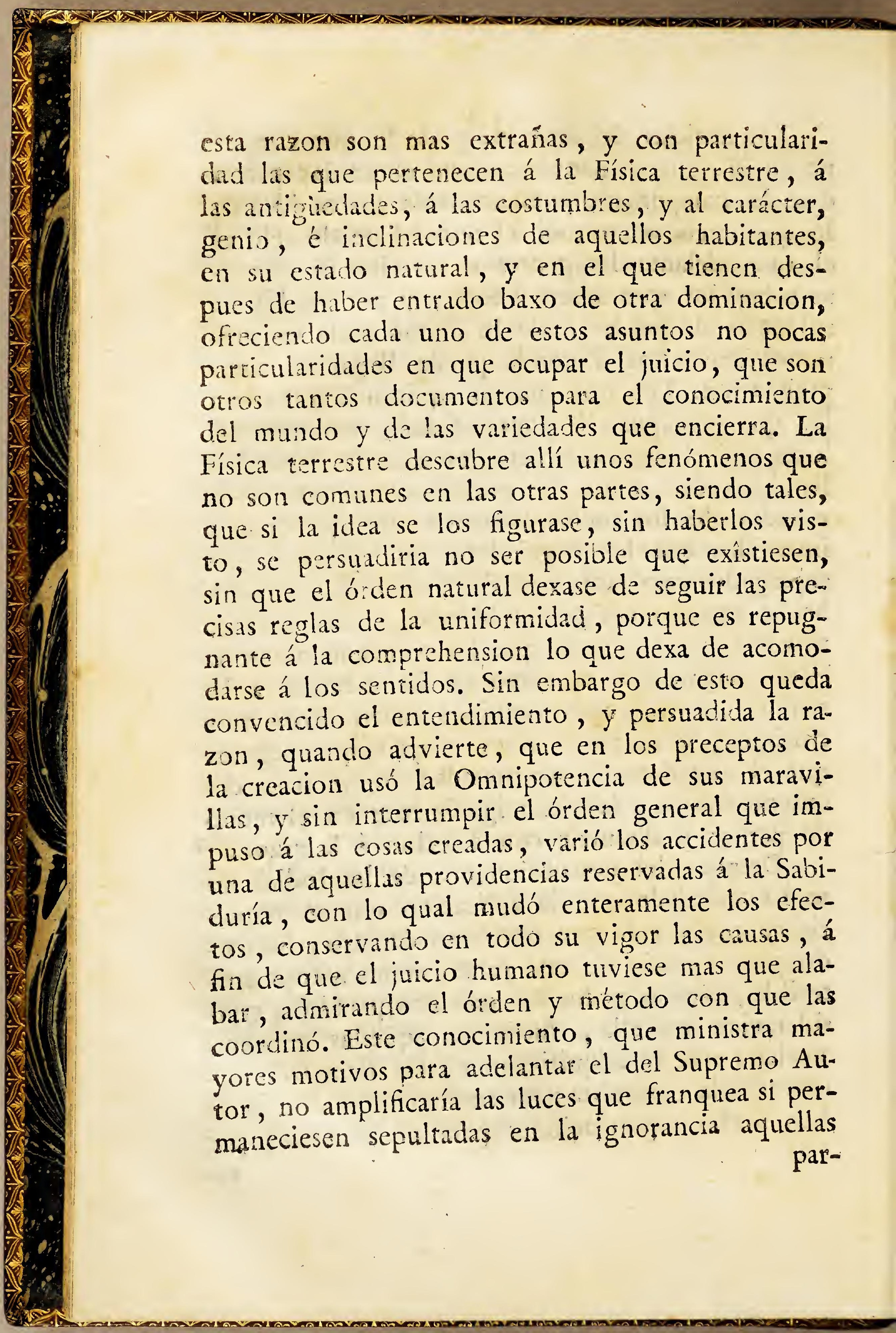


particularidades; y así quando de ello no se sacase otro adelantamiento mas que este, bastaria para arrastrar el desvelo y la aplicacion de los hombres.

Los fosiles y petrificaciones marinas son el conocimiento demostrativo de los acaecimientos ded mundo, cuya parte no es la que ménos int resa, aun separando la que pertenece á la instruccion, considerada como mera curiosidad. En ella se descubre, que aquella diferencia sensible que varía los territorios, no fué impedimento para que participasen con igualdad de unos mismos accidentes, conservando señales que lo/testifican, sin dexar de ello equivocacion. Estos monumentos llenan de confusion la incredulidad, siendo bastante motivo para que merezcan en todos tiempos la mayor aceptacion, y el aprecio de los hombres sabios, que apoyando en ello las verdades mas recomendables de la $\mathrm{Fe}$, han conseguido combatir con señales palpables, que no admiten interpretacion, la temeridad de los impíos, reduciéndolos á confesar la realidad, contra lo que la malicia les inspiraba.

El conocimiento de los diversos pueblos de la tierra, sus usos, costumbres, é inclinaciones, ilustra el entendimiento, dando luz de lo que se diferencian entre sí : unos inclinando á la mayor cultura, y al adelantamiento de las luces naturales, y de la razon; otros declinando al estado de la mayor ignorancia en la vida inculta y animal, al trato torpe y tosco, semejante al de los brutos , y á la impropiedad en todas las acciones. De esto se saca el provecho de saber estimar la ins*

truc. 


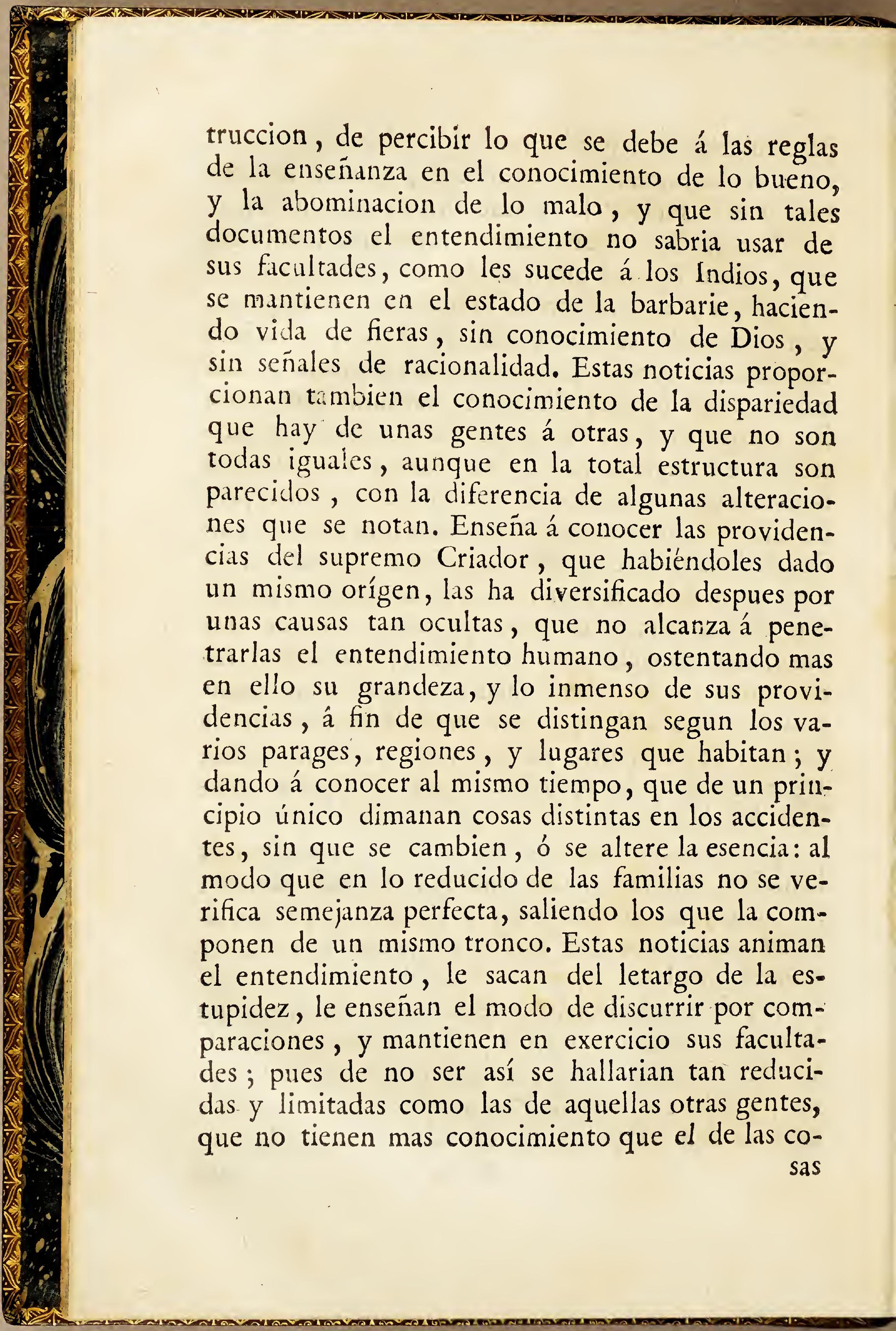


sas presentes y forzosas para la vida.

Las memorias de la antigüedad son las demostraciones verídicas de lo que fuéron las gentes en los tiempos á que se refieren: por ellas vienéa averiguarse lo que alcanzáron, el modo en que se manejáron, su gobierno y economía ; y á este respecto lo que han adelantado ó perdido, lo numeroso de. sus gentíos, la industria, el valor, y las máxîmas de manejarse: sin los monumentos, que, sin embargo de la ruina de los tiempos, se conservan en alguna parte, no habria documentos formales por donde inferirlo. De ellos se comprehende la semejanza que tuvieron unos pueblos con otros; y por este medio llega, en aquella forma que es posible, á desentranarse su orígen, que es una de las particularidades que mas incitan el deseo, comosucede con los Indios, que por estar separados de las otras tierras, y por tener disonancia en el color, y en otros accidentes de la contextura, dificulta el juicio el modo de haber transitado á poblar, y el orígen de donde saliéron. Estos asuntos serian de la mayor confusion para el entendimiento, si no se les encontrase una solucion regular en los vestigios de las cosas, en los usos, las costumbres, y las demas particularidades que descubre la investigacion, ayudada de la inteligencia.

Estas son las ventajas que se adquieren con las noticias de la antigiiedad, con las relaciones de lo que produce la tierra, con el conocimiento de sus regiones ó temperamentos, y con las luces de la forma y estructura de las partes que constitu2

yen 


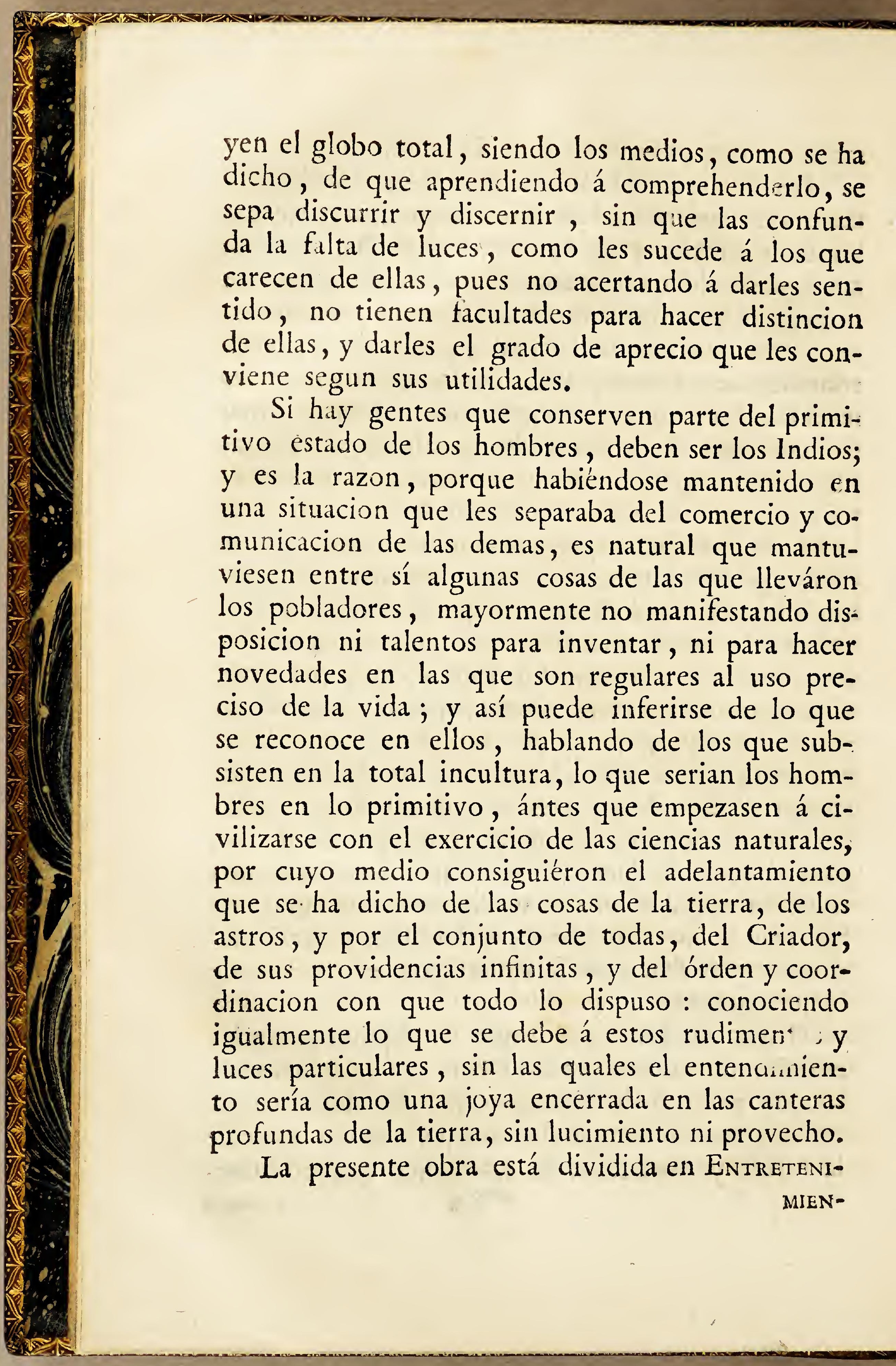


mientos, cuyo título se les ha dado por interesar la curiosidad, al paso que dan instruccion: siendo regular esto en los asuntos que tratan de materias de Física, y de la Historia de los pueblos, las quales se hacen gratas á los Lectores por las luces que les ministran de las cosas poco conocidas; pero con particularidad quando se reconoce sobresalir en ella el estilo de la verdad, con preferencia al de admiracion que causa lo raro, cuyo defecto suele experimentarse tratándose de regiones distantes, mayormente si ha faltado el escrúpulo con que se deben exâminar las que son poco comunes: sucediendo no pocas veces errarse el concepto que se forma de ellos, ó dar demasiado valor á las exposiciones de la vulgaridad; y de incurrir en uno ó en otro defecto se sigue sorprehender al público, llenándole de especies inciertas, que admite gustoso por la propension que tenemos á lo que da mas golpe en los sentidos. Aquí se han procurado salvar estos defectos, haciéndole una pintura exâcta de las cosas, y descifrando lo que representan de extraordinario, con el juicio de las causas, de donde procede la desigualdad, para que en este modo, al paso que divierta su lectura, se registren en aquellos paises retirados la diversidad de los territorios, las distintas especits de cilmas y temperamentos, las producciones, con todo lo demas que encierran, y quede satisfecho el entendimiento, encontrando la razon de todo ello: reconociendo al mismo tiempo que las diferencias sensibles que tienen, á lo que es regular en el conocimiento comun de las gentes, es preciso que 
sean así, por hallarse conformes á los accidentes que ocasionan la variedad.

Solo resta desear que el público, siendo el interesado, por haberse escrito á su beneficio, la reciba como prueba de los fines que han movido á hacerlo, franqueándole las noticias que por sí no puede alcanzar, y el medio de que registre otros paises distintos de aquellos que cada individuo conoce, ú otros fenómenos, otras gentes, otros animales, y otras producciones: si con estos fines se logra tener su aprobacion, será una recompensa muy apreciable y correspondiente al trabajo que se ha impendido en escribirlas, y á los afanes de la aplicacion en el cuidado de observar con prolixidad las cosas mas notables del mundo, y las obras maravillosas de la Naturaleza. 


\section{T A B L A}

\section{DE LO QUE CONTIENEN LOS Entretenimientos de esta obra.}

$\mathbb{F}_{\text {ntretenimiento I. : Sobre las varias disposiciones }}$ que tienen los territorrios en diferentes partes de la tierra; y los efectos que esto ocasiona en los temperamentos, no ménos que en las producciones. Pag. I II. El órden y disposicion en que están los terrenos de las Indias Occidentales, $y$ de la notable variedad que bay en ellos.

III. Se explican los temperamentos y climas de los diversos territorics de aquellas partes del mundo.

IV. Continúa scbre los varios temperamentos.

V. Sobre los distintos temperamentos de la parte alta de la América, efectos que producen, y causas de lo que alli se experimenta contra el órden general de las otras partes.

VI. De las producciones vegetables de los varios territurios.

VII. De los animales, $y$ sus particularidades.

VIII. De las particularidades de los volátiles.

IX. Sobre los pescados particulares.

$\mathrm{X}$. De los lagos y de los rios, dando noticia de lo que contienen de particular.

$\mathrm{XI}$. De las dolencias que son particulares, segun la variedad de los climas, y su comparacion.

XII. De los minerales, principalmente de los de pla-

ta, $y$ del modo de entablar su trabajo.
XIII. Continúa el asunto de los minerales, y se explican quales son las principales caxas, y lo que se funde de plata en ellas.

XIV. Sobre el estado actual de las minas, $y$ las que se benefician por el fuego ó por el azogue. 


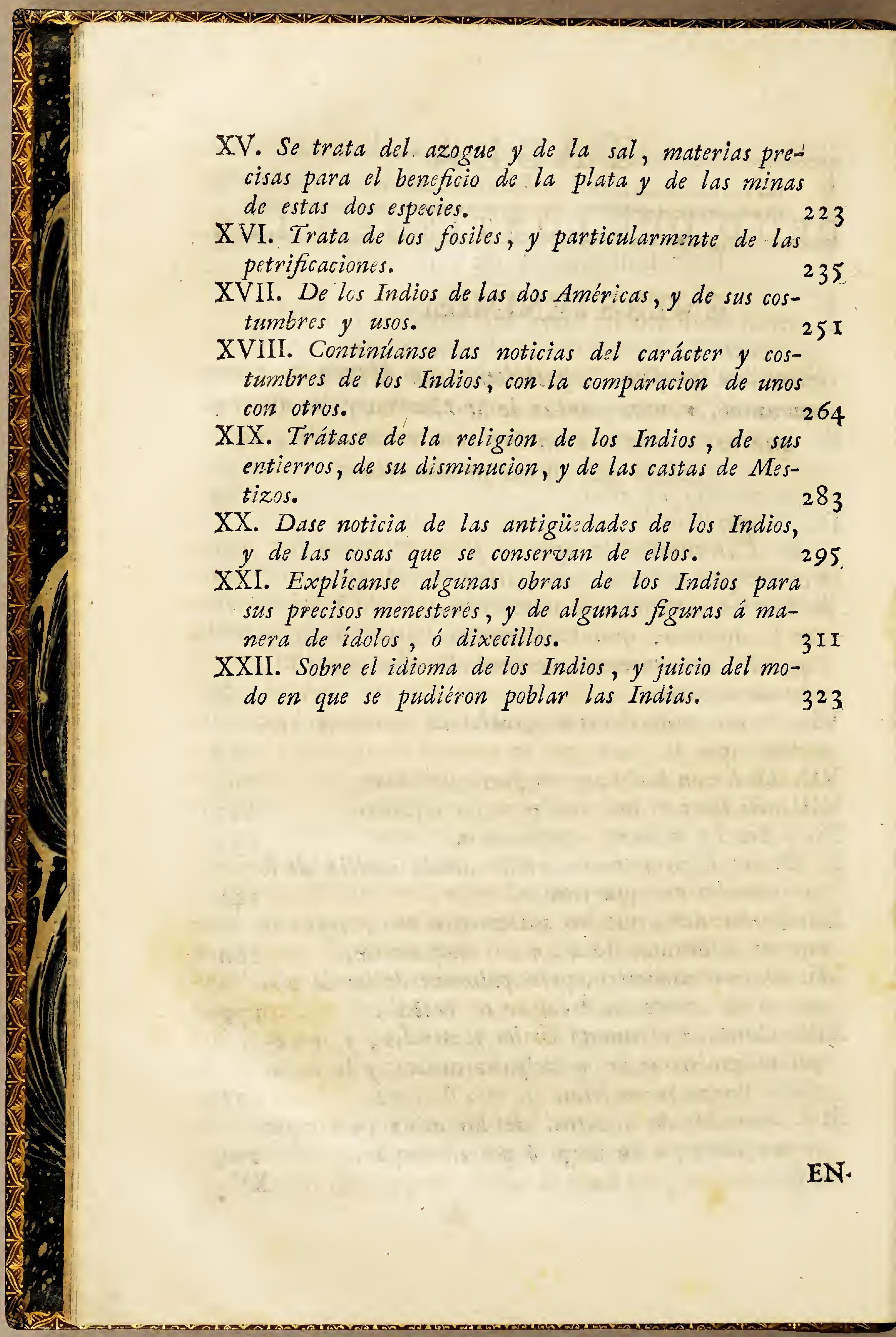




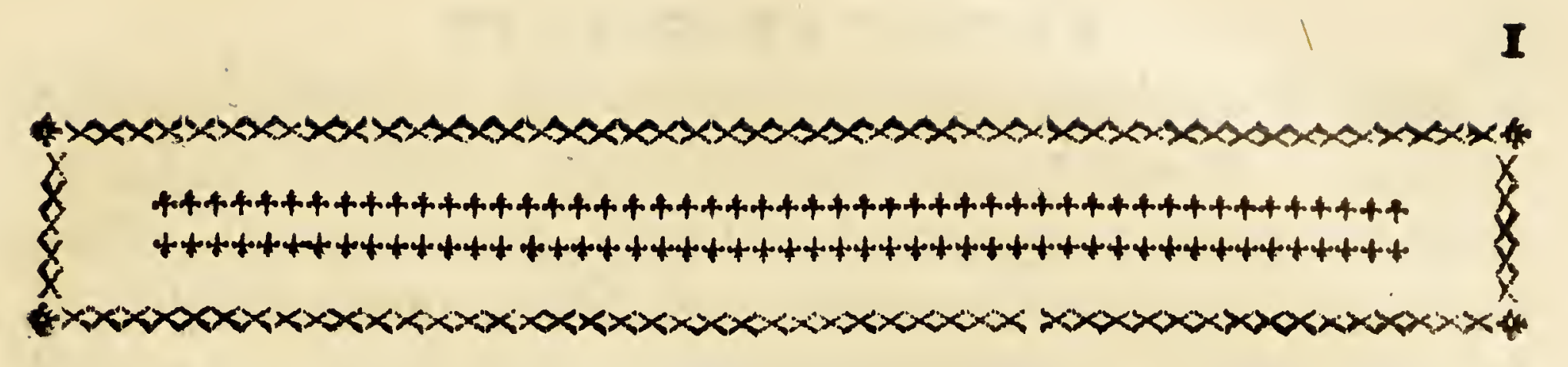

\section{ENTRETENIMIENTO I.}

Sobre las varias disposiciones que tienen los terrenos en diferentes partes de la tierra; y los efectos que esta ocasiona en los temperamentos, no ménos que en las producciones.

I $\mathbb{E}_{s}$ admirable ja naturaleza en todas sus obras, y participan de esta prerogativa con singular recomendacion las distintas disposiciones que dió á los territorios, supliendo con la hermosa variedad en que los dispuso, las ventajas que dexó de franquearles en las recomendaciones de los lugares que les destinó. Por este medio repartió sus apreciables dotes tan generalmente, que al paso que se esmeró en ostentar su fecundidad con los mas pingües, no dexó de comunicar sus prodigios á los que parecia tener ménos ventajas; bien fuese por la situacion en que están, ó por los accidentes que concurren en ellos. Acostumbrados á aquello primero en que nos criamos, se nos hace dificil comprehender, que los paises que no conocemos puedan ser diferentes de ellos; ó que siéndolo participen de las propiedades que son regulares en los que habitamos: sin exceptuarse de estas dudas los sugetos mas instruidos, los mas aplicados y estudiosos, ni aun los que miden los arcanos de la naturaleza con la especulacion. Todos incurrimos en esta flaqueza, como efecto indispensable de nuestra limitacion; y esto procede de que lo que se considera con las luces del entendimiento puramente, no hace la misma impresion que lo que 
se toca desde luego con los sentidos, y pasa de ellos al convencimiento del alma. La Zona Tórrida hace muchos años que se conoce habitada: pero no hace tantos que entre los hombres sabios y físicos consumados se comprehendió, que no solamente era habitada, sino que hay en ella regiones dilatadísimas, en que se experimentan los efectos de la frígida y de la templada. No se ignoraba que habia montañas en las inmediaciones de la Equinocial, pero no se comprehendia bastantemente que la ménos densidad del ayre moderaba de tal modo los efectos de los rayos del sol, quando están mas perpendiculares sobre la tierra, que pudiese ser esto un equivalente á la obliqüidad que tienen, quando este astro se halla mas apartado del Zenit, y que produzca nieves, hielos y frialdad por este medio, como en las regiones que se acercan hácia los polos. Tampoco se alcanzaba á comprehender, que en los parages en donde el ayre llega á tener una dilatacion tan considerable, que á corta diferencia es la mitad de la que por naturaleza tiene sobre la superficie total de la ticrra; considerada llana como lo están los mares, pudiese haber vivientes. No entendian que pudiese haber parage en donde perennemente se experimentasen los efectos de los quatro tiempos del año, sin que en la duracion de los dias y las noches hubiese variacion sensible. Tampoco podian concebir los que habitan en aquellas partes, en donde ni el frio ni el calor molestan, que se pudiese resistir á la alternativa continua de invierno con frios excesivos, y de verano con calores extremados. A unos les parece cosa rara la igualdad de los dias $\mathrm{y}$ de las noches, sin ignorar la razon que lo dispone así; y á otros, sin carecer de la que hay para la desigualdad, les parece que será penosísimo á la vida acomodarse á unas noches largas, y pasar despues á tenerlas aun mas cortas que lo fuéron los dias en aquella precedente estacion.

2. Muchas otras cosas se hacen difíciles á la creduli- 
PRIMERO.

lidad, hasta que la experiencia fecundiza las ideas de la comprehension, y desvanece la repugnancia en lo que parece ménos regular. La naturaleza, próvida en todas sus obras, sembró el mundo de maravillis, sin sujecion á la limitacion de los entendimientos: siendo ella misma la que con facilidad enseña la coniordancia que les dió, distribuyéndolas con tal igualdad, que lo que parece mas raro en unas partes, es comun en otras. Por este término vienen á quedar iguales entre sí, sin que tengan que envidiarse, porque en todas se vive con regularidad; y la vida, que es la prerogativa mas principal de las criaturas, no tiene ventajas en los paises que logran una primavera continua, sobre los otros en donde entre el estío, el oroño y el invierno componen las tres quartas partes del año. En todos sub isten las gentes y los animales; y las particularidades de los climas benignos no tienen privilegio para alargar la vida, respecto de los que habitan en otros llenos de molestias y pensiones. Los rigores del calor son tan propios á los que se habitúan á ellos, como los destemples del frio á los que están acostumbrados á sobrellevarlos; y como si la naturaleza hiciese fuego de sus accidentes, iguala entre sí los temperamentos mas distantes dentro de una misma region, colocando en los ardores de la Zona calurosa las frialdades de las partes glaciales. Esta sola circunstancia basta para que no caulse repugnancia lo que parece ménos conforme; pues á vista de unir los dos extremos mas opuestos, queda persuasible todo lo demas : si los propios hechers no lo demostrasen; no se creeria que podrian estar unidos baxo de un mismo distrito el calor y li frialdad, el fuego y el hielo, las lluvias abundantes y la estcrilidad de la nubes, sin mas distancia que los separe que la elevacion; pero la naturaleza, maestra de los mayores prodigios, se gobierna por leyes tan sabias y tan próvidas que lo abraza tcdo.

3 Los paises remotos, y particularmente los de A 2 las 


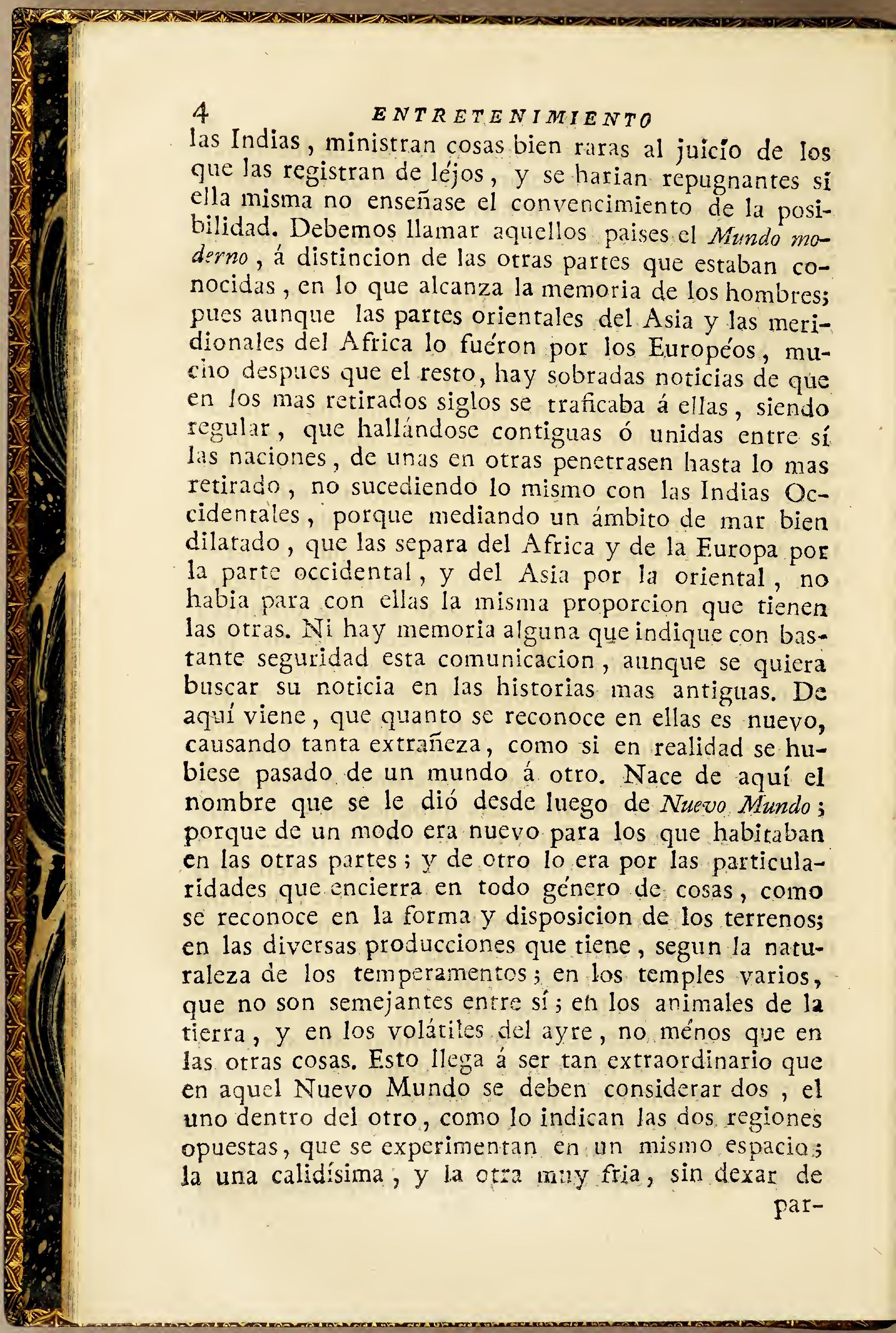


PRIMERO.

participar ambas de una propia direccion de los rayos del sol; y como si estuvieran apartadas de una quarta parte del globo, se experimentan climas, fenómenos, y efectos enteramente diversos y encontrados: pues se ven los de las partes medias del Africa, y los de las mas septentrionales de la Europa, que es quanto puede observarse de mas raro en la naturaleza.

4 Muchos hombres sabios y curiosos se han dedicado con aplicacion al conocimiento del mundo, por el de sus producciones; con cuyo designio han formado gabinetes prolixos y abundantes de quanto se produce en sus distintas regiones, y se cria en los particulares territorios de ellas : cuyo trabajo da solo conocimiento de una parte de lo raro, sin extenderse á dar luz de las principales particularidades, que consisten en la física de la corteza ó parte exterior del globo, que es en la que reside la propiedad y causa primitiva de las producciones. Estas se hacen recomendables por su particularidad al juicio de los que no tenian noticias de ellas, y quedan preocupados de la misma novedad, sin penetrar el crígen, ínterin que no lo desentrañan : para ello se requiere una aplicacion prolixa, y exâminar las causas, que son el fundamento de quanto se observa de mas extraño. Las producciones, en las tres clases en que los físicos dividen la naturaleza, dan luz de lo que puede formar la combinacion y concurso de los climas; pero dexa en confusion la parte mas principal, que es la matriz en donde se imprimen sus influxos, para que resulten de ello las producciones: esto es lo que debieran haber explicado; pero escasos de noticias no han podido pasar adelante con sus deseos.

5 Los gabinetes de Historia natural son sin duda los archivos de la naturaleza, en donde la curiosidad registra lo admirable y lo raro que se encuentra en diversas partes del mundo : esta especulacion no es suficiente para dexar satisfechos los designios del entendimiento en el empeño de conocer fundamentalmente 


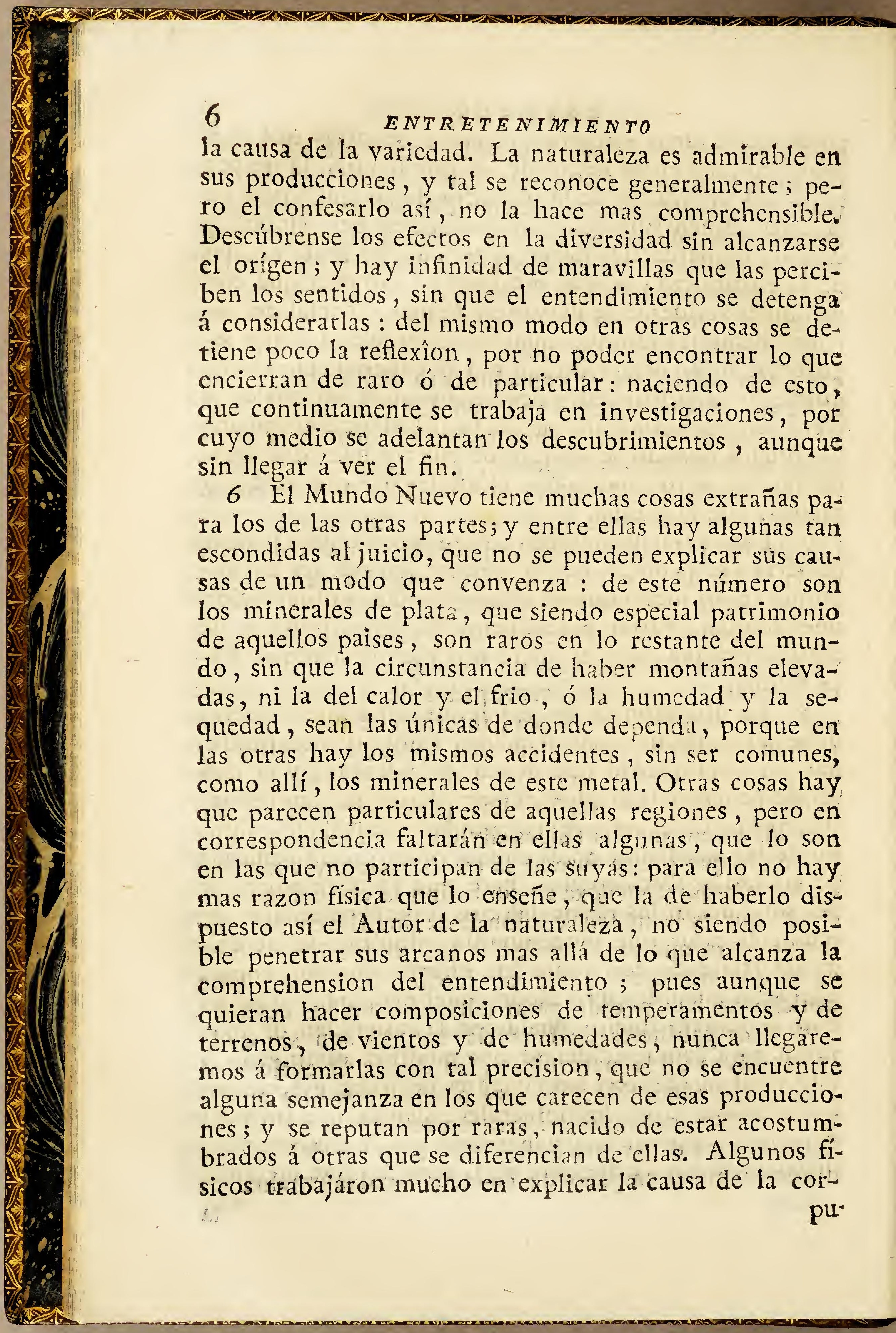


pulencia de unas naciones respecto de otras que son pequeñas: del color negro de las que habitan la mayor parte del Africa, y de la blancura de las que viven en las mas septentrionales ó meridionales del globo; y despues de parecerles haber adivinado las leyes ocultas de la naturaleza, se ven precisados á conocer que con qualquier accidente se desvanece 10 mas esencial del sistema, demostrándo que quanto se establecia como seguro, se halla desacreditado por la experiencia: continuamente se palpan estos desengaños; con los quales se viene en conocimiento de la facilidad que acompaña los juicios quando se separan de ella; y que para acertar no hay otro camino que el de llevarla por guia, y razonar con la misma.

7. Las causas primitivas de quảnto se registra sobre la tierra, se explican bastantemente por las reglas comunes; pero luego que se encuentra nueva observacion que desdiga, varian enteramente los principios; y de aquí se origina, que el juicio mas bien fundado se hace falible:

8 La direccion de los rayos del sol sobre la tierra debe ser causa del mas ó ménos calor; y nos fundamos en la propiedad que tienen de calentar, y el modo de penetrar la atmósfera para hacer su impresion: sin embargo de ser este un principio innegable, alguno de los accidentes del segundo órden, como sucede en las Indias Occidentales, hace que varíe en parte; y no solo dexan los rayos directos ó perpendiculares de causar el calor que correspondia, sino que se experimenta frialdad, con todos los efectos que son conseqüentes á ella; de cuyo modo aquel principio; tan seguro á nuestro juicio, muda con la casualidad de concurrir otra causa àccidental que modifica su fuerza. A este simil sucede con los vivientes de todas especies en los vegetales $y$ en los minerales, siendo preciso para no errar en los juicios, gobernarse por la observacion, sin atender á los principios de la teórica, que determi- 


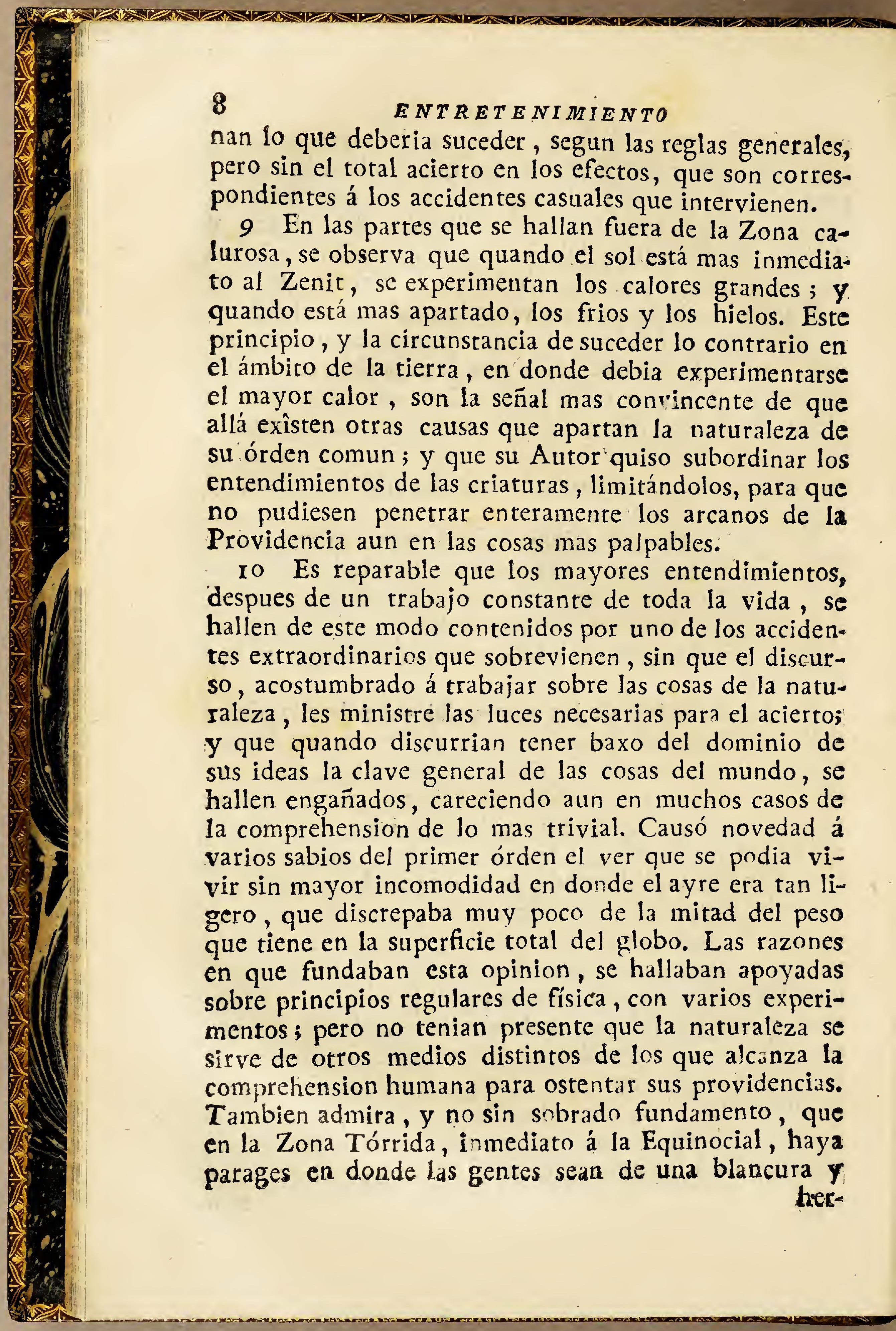


hermosura, de color tan particular, que tho tengan que envidiar en ello á los paises mas señalados de la Europa, ó del Asia; y que los accidentes del temperamento no influyen en ellos, como sucede en otras partes en donde son de color ménos blanco: los que concurren en unos hacen variar la regla general de los otros; y estas son las providencias admirables de la naturaleza. Muchas otras cosas se notan en aquellos parages, que no son ménos extrañas que las antecedentes; y si hasta aquí no se ha tenido puntual conocimiento de ellas, es por no haber habido quien se dedicase á observarlas, y hacerlas comunicables con la extension y prolixidad que merecen, despreciándose este género de noticias en aquellos parages, porque la principal atencion la arrastran unos incentivos. que lisonjean la inclinacion de las gentes. 


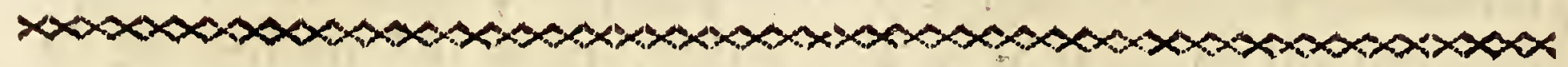

\section{ENTRETENIMIENTO II.}

\section{El órden $y$ disposicion en que están los terrenos de las Indias Occidentales, $y$ de la notable variedad que bay en ellos.}

Se reconocen de ordinario, por las particularidades que se notán en los efectos, los atributos de las causas: así sucede en la naturaleza, que por las obras se hacen perceptibles las singularidades de su providencia; y lo confirma la variedad que reyna en ellos, sin apartarlas de las leyes precisas para la subsistencia. Si las cosas fuesen en sí iguales, sin desproporcion, no habria motivo para que tuviese que admirar la especulacion, ni para hacer comparacion de unas con otras. La uniformidad es de ordinario poco recomendable á los sentidos, porque no se distingue en ella cosa que sobresalga y llame la atencion: por el contrario, la variedad suspende la atencion á la primer vista de los objetos, que no siendo semejantes tienen una misma perfeccion, sin ser dable discernir qual sea mas completa en su especie. Una montaña y un valle son dos cosas diferentes; y si en la primera admira la especulativa la corpulencia y las desigualdades de que se compone, no se recrea ménos en la llanura é igualdad del segundo; pero un llano dilatado, donde se pierde la vista, molesta tanto como una serranía continuada; y parece que en esta y en aquel hace falta la variedad, para que los objetos se diversifiquen, y no sean siempre unos mismos. En la tierra dispuso la naturaleza llanuras, montañas, valles, desigualdades, riscos, lagunas, rios caudalosos, arroyos, fuentes, y aun dió á la tierra varios coloridos para que no fuese todo una misma cosa, y que 
Ia alternativa de unas con otras hiciese mas completa la obra. A esta semejanza no hizo las partes de la tierra con rigurosa igualdad; pero le dió á cada una cierta forma en su estructura, ó en las producciones que le señaló, por donde se distinguiese de las demas. Esto lo hizo sin apartarse de las reglas generales que guardó con todas, cuya circunstancia es otro aditamento muy recomendable. La parte meridional de las Indias Occidentales, conocida por América Meridional, se diferencia de las otras sensiblemente en su\& dilatadas llanuras, y en sus elevaciones considerables, que tienen el nombre de Cordilleras, siendo tan espaciosas, que parece haberse dispuesto un pedazo de mundo superior al otro, en bastante altura, y dentro de él, tan desemejantes entre sí, que quasi no se parecen; porque lo material de los territorios, la disposicion y simetría de sus partes, las estaciones del año, los temples, las producciones, y los animales, todo es diverso, ó se halla encontrado: siendo muy particular, que en un propio continente, y no á muchas leguas de distancia, sea verano en una parte mientras es invierno en otra; y al contrario, que los árboles que produce el un territorio, sean tan distintos de los del otro, como si entre ellos mediasen centenares de leguas; y que en los frutos, animales y. aves suceda esto mismo. De aquí resulta poderse conceptuar, segun queda dicho, como dos mundos distintos dentro de uno.

2. El ámbito de la Zona Tórrida, que es el que hay, desde el un Trópico al otro, coge toda la isla de Cuba, la de Santo Domingo, con orras; y la ciudad de la Habana se halla á muy corta diferencia debaxo del de Cancer, extendiéndose hasta Morro-moreno, cerca de la bahía de Mexillones, al Sur, cosa de un grado del puerto de Cobija, en las costas del mar del Sur, y paises del reyno del Perú. Los climas que se reconocen en estos 47 grados son muchos, y la va$\mathrm{B}_{2}$

ria 
I2 ENTRETENIMTENTO

ria dísposicion de los territorios lo mísmo; á cuyo respecto son las producciones, sin que esto siga un órden preciso, por el qual los que se acercan mas á la Equinocial sean los mas cálidos; ni por el contrario mas moderados de las influencias del sol los que se hallan mas próxîmos á los Trópicos; cuya disonancia no la alcanza la especulacion de la física sin el auxilio de la experiencia, mediante que en el órden natural correspondia, que el calor mas intenso estuviese en la medianía del espacio que anda el sol en el discurso del año, y que fuese moderándose á medida que se aparta de aquel punto: esta contrariedad hace rara la cosa, originándose de ello el deseo de averiguar la causa; porque lo extraño, segun el órden natural de las cosas, mueve la curiosidad á des. cubrir el orígen que tiene, y á penetrar los secretos de que se sirvió la naturaleza para apartarlo de las reglas comunes de su providencia.

3 No son todos los territorios del espacio del globo, segun se ha dicho, semejantes: hay en él paises muy baxos, otros que son alguna cosa altos respecto de aquellos, y otros que son altísimos: de estas diversas graduaciones procede despues la variedad de temperamentos, que son la causa accidental ó segur$\mathrm{da}$ de la desigualdad que se experimenta en ellos. La isla de Cuba, considerada por sus costas, es en mucha parte baxa, y en parages tanto, que parece estar igual con el mar, lo que se nota particularmente en los que llaman Cayos. Por lo interior de ella se ven montes y alturas; pero no son estos de una elevacion comparables con otros que hay en distintas partes de la tierra. La isla de Jamayca, que dista po. co de la de Cuba, y está á la parte del Sur, es alta en forma de montañas, desde las orillas del mar, hácia su interior; haciéndose reparable, que en un ámbito tan corto como el que las divide, se encuentre esta disparidad, pues en dias claros se ve desde la 
primera la de Jamayca. Las costas de la América Meridional, que miran hácia el Norte, son en lo general de una altura regular, descubriéndose en ellas hácia lo interior montañas medianas, y en ciertos distritos serranias tan altas, que se dexan ver desde mucha distancia; siendo tanto lo que se elevan, que hallándose poco apartadas de la Equinocial, están cubiertas de nieve, excediendo aquel punto de la atmósfera, en donde se forma la congelacion. En las partes occidentales de la América Meridional, que es de las que se ha de tratar principalmente, se ve de todo; pero las tierras que se reputan por baxas, no lo son tanto como se ha dicho de la isla de Cuba y Golfo Mexicano. Las costas que siguen por el Occidente del mar de Cartagena, desde Honduras, por Yucatán, Golfo de México, dando la vuelta por Ia Luisiana y Florida, y las que corren hácia la Nueva Inglaterra por el Canal de Bahama, son igualmente baxas y rasas, en tanto grado, que parecen á un nivel con el mar, así como los Cayos de la isla de Cuba.

4 Esta parte de la América Meridional y Occidental es principalmente la que representa el particular fenómeno de la desigualdad en territorios, y conseqüente á ellos en los climas y producciones, debiéndose mirar como dos paises díversos en uno mismo. El ámbito que mira hácia el mar del Sur es baxo, formando como una faxa, que corre desde el Chocó en 7 úl 8 grados de la parte del Norte de la Equinocial, hasta los 26 ó 28 de la del Sur, cuya anchura es con variedad desde 8 hasta 20 leguas, ensanchándose en unos parages mas que en otros. Desde donde fenecen estas llanuras baxas empiczan las serranías que llaman Cordilleras, elevándose tanto, que parece ir á rematarse con las nules. Allá en lo alto forman otro pais, interrumpido en lo dilatado de sus distancias de varias montañas y quebradas; y este se extiende en lo largo todo lo que tiene aquella Amé- 
rica; pero en lo ancho es con variedad de 30 á 50 leguas: al fin de ellas, por el lado del Oriente, vuelven á descender las serranías para formar otro pais baxo, que es el que corre desde su pié hasta las orillas orientales de la misma América en el Brasil; siendo esta á la que allá se da el nombre de Montaña de los Andes, nacido de dos razones: la una, porque aunque es pais baxo, no faltan en él montes, ni dexa de ser escabroso y desigual en partes; la otra, por ser: poblado de bosques espesos, que es á lo que por allá dan el nombre de montaña, aun quando el suelo es llano. De esto se ve, que en lo interior de aquella América hay una faxa de territorio sensiblemente mas alto que todo el resto, y mas que los paises habitados de las otras partes del mundo; porque su elevacion es tanta, que excede á las que se conocen en ellas, como lo tienen demostrado los experimentos $y$ medidas que se han hecho para su averiguacion.

5. En esta parte alta de la América hay luego otros cerros, que se levantan de su suelo á unas alturas considerables, to mismo que sucede en los paises mas conocidos de Europa; pero en la parte poblada alta, que les sirve de basa, hay provincias, y aun reynos de mucha extension y gentio: hay tambien en ella despoblados dilatados; $y$. como si fuese otra tierra distinta de la baxa, varía todo allí en tanto grado, que quasi no hay cosa que sea igual del uno con el otro; debiendo ser así, porque variando el clima, varían todas las producciones de la tierra. Es conveniente para la inteligencia segura de esta tierra superior, no equivocar la que llamamos parte poblada alta con la mayor elevacion que tienen los montes y serranías que se levantan de ella; y para esto se debe suponer, que la parte habitada tiene de altura, respecto de las tierras baxas que están inmediatas al mar, $4536 \frac{2}{3}$ varas; pero las cumbres de las montañas, que nacen de la misma planicie alta, tienen mas de 6600 varas, $y$

con- 
conseqüentemente respecto de aquella 2 roo. Así se establecerá haber tres graduaciones de tierra, que son la baxa, que está contigua al mar: la alta que está en lo corpulento de la cordillera, ó serranía; y la mas alta, que son las montañas que se levantan de esta. Si estas alturas fuesen con poca diferencia semejantes á las de las montañas de que se tiene noticia en las otras partes del mundo, no darian asunto para que se reputasen por cosa rara; pero no es así, su elevacion excede á lo que conceptuaba el juicio, originándose de ello lo extraño y particular que se nota, y la diversidad de cosas nada comunes que proceden de este principio.

6 En el territorio baxo dominan los areniscos, y esto sucede en distancias bastante dilatadas : hay tambien algunos espacios de tierra limosa. Como no faltan montañas en algunos parages, hay en ellas canteras, y toda esfecie de tierras, como es regular en todos los paises que tienen extension. En la parte alta, que asi la nombramos mirada en total, no faltan espacios bien grandes de arena, infiriéndose de ello no poderse absolutamente atribuir á la inmediacion del mar los largos terrenos de esta especie. Parece que la naturaleza andubo jugando con sus obras al disponer aquella parte del mundo, y que para interrumpir el órden de los climas formó un pedazo de tierra sobre otro, sin diferenciarlos mucho en la especie; pero poniendo tan elevado el uno, que tuviese semejanza con los que están mas apartados.

7. La tierra alta se dilata con corta diferencia tanto como la baxa, corriendo desde las partes que corresponde á las costas de Caracas, Santa Marta, Cartagena, y el Chocó, hasta muy cerca del Estrecho de Magallanes; pero con una particularidad, y es, que así como lo mas ancho de la América está en la Equinocial, y sus inmediaciones, es tambien lo mas ancho y alto de la tierra alta en este parage. La tier- 
ra de esta América, mirada en su totalidad, va estrechándose á proporcion que corre hácia el Sur, y lo mismo le sucede á la parte alta; pero hay otra particularidad mas, y es, que desde los 30 grados, Sur en adelante, el clima es correspondiente á las mutaciones de la Zona templada en las divisiones de invierno y verano; y como ménos necesario de alli en adelante suplir con la altura lo que falta á la naturaleza del clima, fué haciendo algo mas baxa la alta de lo que está en la Equinocial: de modo que esta, que puede figurarse como una colina de imuchos centenares de leguas, va siendo mas estrecha, y menos elevada, quanto se acerca mas á las partes meridionales, fo qual es reguiar en este modo, porque de lo contrario sería intratable por lo muy frio en tiempo de invierno; pues si la tierra de la Equinocial, por razon de su mucha elevacion, es fria de continuo, conservándose cubiertos de nieve todo el año los cerros; si esta altura en la Zona templada, en donde hay invierno y verano, fuese la misma, se duplicarian las causas de la frialdad con la obliquiidad de los rayos del sol, y sería intolerable por la mucha nieve y hielos que la cubririan; y así, próvida la naruraleza en sus obras, se manejó en esta de tal modo, que disminuyó la causa accidental que puso allá para que en nada hubiese exceso. En aquellas cordilleras de la parte mas al Sur no se han hecho experiencias del barómetro, como en las de la Equinocial, y solo puede conjeturarse por el juicio prudente de la vista, y por lo que indica el grado de frialdad en el verano: convendria mucho asegurarlo con observaciones formales. No se trata en esto de lo que se elevan las otras montañas y serranías sobre la tierra alta, porque en aquellas, como que no las disponia para que fuesen habitables, dexó de ceñirlas á la regla que guardó en las segundas; y así se ve, que quando en las Provincias que están entre los Trópicos son tratables

en 
en todos los tiempos las serranías altas, las que están de los $3^{\circ}$ grados en adelante no lo son en $\mathrm{el} \mathrm{in-}$ vierno, porque la abundancia de la nieve, que cubre la tierra, no lo permite.

8 No son comparables aquellas dos tierras alta y baxa con las que se ven en las demas partes del mundo; porque aunque en todas hay serranías dilaradas, y en sus alturas y valles no faltan poblaciones, sin embargo de las nieves que caen en ellas en sus tiempos, no se encuentran las llanadas extendidas que en las de allá, siendo tales, que estando allí no parece hallarse sobre los pináculos de la tierra; y así los nacidos en aquellas eminencias, que no han salido de su patria, juzgan que toda la parte habitable del globo está en la misma altura ó nivel, sin figurarse la gran distancia perpendicular que el mar es. tá mas profundo que ellos; y al contrario, los que nunca subiéron á aquellas cumbres no pueden comprehender la diformidad de la mole de tierra que se halla levantada sobre la planicie regular del mundo, constando de muchos centenares de leguas en lo largo, y de bastantes en lo ancho.

9 La tierra está en aquella parte alta entrecortada 'de aberturas ó quebradas, segun allí las nombran, de una anchura muy grande; siendo estas el ámbito que dexan entre sí unas llanuras ó serranías con las del lado contrario; y son tales, que tomadas por el ayre tienen algunas dos leguas ó mas de anchura : estas van estrechándose tanto, quanto son mas prufundas, y por lo mas hondo es por donde corren los rios, llevando su cauce á corta diferencia por la medianía y en la parte baxa de los quebradones, por los dos lados, dexa otras llanuras de competente extension. Lo notable es, que las vueltas y tortiosidades que hacen los rios, corresponden á las que forman las al-. turas de los dos lados; de tal modo, que si se llega-

$$
\text { C. sen }
$$


sen á juntar, se ajustarian exâctamente la una con la otra, y formarian un territorio seguido sin rotura alguna. Estos rios van continuando su carrera siempre por entre aquella caxa de montañas hasta salir al terreno baxo, y de allí al mar; pero el cauce que forman en esta segunda parte es de poca profundidad, hallándose á corta diferencia como en la superficie de ella : de esto se puede colegir, para formar verdadera idea, que quanto son mas elevadas las cordilleras, los cances de los rios son mas profundos: la abertura de las tierras es mas ancha por la parte de arriba, y en lo profundo son asimismo mas espaciosas las llanadas que acompañan al rio, que es á lo que alli dan el nombre de valles, á imitacion del que tienen los paises de la parte baxa de la América, que los distinguen con el propio nombre, á distincion de la habitada alta, que llaman sierra.

io En la Provincia de Angaraez, entre los muchos juegos de la naturaleza, que son tanto mas vários y maravillosos, quanto son los paises mas espaciosos y dilatados, se observa una cosa bien particular : consta aquella Provincia, que es la que pertenece al Gobierno de Guanravelica, de várias doctrinas ó partidos: en una de ellas, que se llama de Conaica, hay un pueblo pequeño llamado Viñas: en là distancia que corre desde este hasta el principal Conaica, que es de 9 leguas, se pasa á las 5 de ellas un cerro nombrado Corosunta: báxase de este, y se entra en una abertura, por donde corre el rio que llaman Chapllancas; este, por espacio de media legua, va encallejonado por una caxa, cuya anchura es de 6 á 8 varas y mas de 40 de altura, sin ensancharse sensiblemente por la farte superior mas que por la de abaxo: por cste suelo, que en donde se angosta ocupa el rio todo su ancho, va el camino que conduce al pueblo de Conaica, y solo en los ámbitos donde la 
anchura es de las 8 varas que quedan dichas, se transita por la una de las orillas, y se atraviesa nueve veces, buscando aquella en donde se aparta del murallon que forma la caxa; lo qual sucede principalmente en donde hace vueltas ó recodos, porque en donde va derecho no tiene mas anchura que la precisa para darle paso al agua. Esta caxa ó cauce está cortado en peña viva con tanta precision, que las desigualdades del un lado entrantes corresponden á las del otro lado salientes, como si aquella altura se hubiese abierto expresamente, con sus vueltas y tortuosidades, para dar tránsito á las aguas por entre los dos murallones que la forman; siendo tal su igualdad, que si llegasen á juntarse se endentarian uno con otro, sin dexar hueco. El caminar por allí no tiene peligro, porque, siendo peña sólida, no hay el de que se desprenda alguna parte al tiempo de andarlo, y el agua no lleva tanta rapidez que ocasione peligro : con to do esto causa horror, y se estremece el cuerpo de verse encerrado en aquella estrecha caxa, cuya elevacion y la perpendicular, guardan no ménos que la correspondencia de partes salientes del un lado y entrantes del otro, que parece indican quererse juntar en cada instante para volver al primitivo ser que tuviéron.

I I Esta abertura es un modelo de las grandes quebradas, dando á entender lo que fuéron en los principios, quando su profundidad no era mayor que la que tiene ella, y que entónces los costados, que al presente están con regular declive, serian perpendiculares ó poco ménos, como sucede con esta; pero que á medida que el curso del agua fué profundándolos y haciéndolos mas hondos, se han ido derrum.bando por lo alto, no pudiendo mantenerse perpendiculares, en cuyo modo han ido buscando la inclinacion que tienen. A esta semejanza es regular que

$\mathrm{C}_{2}$ con 
con el curso del tiempo, y el efecto que las lluvias, los hielos y el sol hacen en los cuerpos mas duros y. recios, vaya desmoronándose la de Chapllancas, $y_{\text {: }}$ pierda la igualdad de anchura que ahora tiene de alto á baxo, habiéndola conservado mas que otras por la circunstancia de ser de piedra dura, y no hallarse interp lida con betas de tierras fáciles á moverse; pero así como debemos persuadirnos á que solo la flotacion del agua ha socavado aquella madre hasta el punto en que al presente se ve, el tiempo, que reduce á arenas los peñascos mas compactos y duros, irá haciendo el propio efecto para ensacharla por la parte de arriba, de lo qual se ven bastantes señales en los pedazos menudos de piedra que hay en el cauce, y en los que se encuentran en la planicie quando el arroyo sale de la montaña á territorio mas ancho.

I2 Sea por efecto de la flotacion de las aguas, que se haya formado aquel cauce profundo, hasta el estado que tiene al presente, ó por el de algun terremoto que abrió la montaña, para que el arroyo, que ántes iba por otra parte, entrase por allí, no tiene duda que esta abertura es posterior á la disposicion en que quedáron las tierras despues del Diluvio; y que á su exemplo, las quebradas disformes que hay en aquella parte alta de la América las ha formado el tiempo con la flotacion que hace la rapidez de las aguas, pues se observa que en la fuerza con que corren quasi todos los rics de aquella parte, arrastran peñasquerías extracrdinarias de grandes, y en parages dexan en medio del cauce vestigios de lo que profundizan, á modo de dades, de un tamaño excesivo, por no haberlos prdido dividir con la misma facilidad que el resto. En el rio de lscuchaca, cerca del lugar del mismo nombre, hay uno de estos, cuya figura es precisamente como la de un dado, teniendo fuera del agua, quando el rio está baxo, de 7 á 8 varas, y por cada i.: 
lado en quadro como I 2 ; para que este, y otros menores que hay en los rios de diferentes figuras, quedasen así, es preciso que el agua haya ido descarnando las piedras y arenas que estaban contiguas á ellos, y arrastrándolas los hayan dexado desmembrados por todas partes, en cuya forma se mantendrán hasta que, profundizando mas, encuentre por su raiz algunas betas de materia endeble, las penetre, deshaga y debilite su subsistencia: despues de tenerlo vencido en una de las grandes crecientes, en que de las 8 varas solo queda fuera como una, lo arrancará, y hará correr, con cuyo movimiento y el choque que hace contra otras peñas menores, se irá rompiendo y se reducirá á partes mas pequeñas que rueden con ménos dificultad: á esto debe atribuirse verse aquellos rios en todo su cauce, y en las orillas mas cercanas al agua, llenas de peñasquería suelta, y de tamaños tan disformes, que no es posible moverlas con las fuerzas humanas. Para que se pueda formar idea de la profundidad que tienen aquellas quebradas, respecto del ter. ritorio ó suelo habitable de la parte alta de la América, será bien citar algunas experiencias que lo manifiesten. La villa de Guancavelica se halla fundada en una quebrada que forman varias cordilleras de cerros: en ella se mantiene el Mercurio dentro del tubo del barómetro en 18 pulgadas, $I_{5}^{I}$ línea, siendo el medio entre $I \frac{T}{4}$ y $I \frac{3}{4}$, que es la mayor variacion que se experimenta alli : segun esta, es su altura sobre el nivel del mar 1949 toesas, ó $4536 \frac{2}{3}$ varas. En lo alto del cerro de la Mina de Azogues, que todavia es habitable, habiendo otros inmediatos que le superan otro tanto, como él supera á Guancavelica, se mantiene el Mercurio en i 6 pulgadas: su altura sobre el nivel del mar es $2337 \frac{2}{3}$ toesas, ó 5448 varas, con que desde la planicie alta del cerro de la Mina, hasta el suelo en donde está fundada Guancavelica, hay 
9 I $2 \frac{\mathrm{r}}{3}$ varas, que se han profundizado por los varios rios que baxan por aquel cerro despues del Diluvio, los quales van á juntarse con el de Guancavelica, que lleva su orígen de otra parte que llaman el Icbo.

I 3 En el pueblo de Iscuchaca, que dista cosa de una legua del de Conaica (y es del propio partido) y de Guancavelica ocho, la altura del Mercurio es ig pulgadas y io líneas, que corresponden á I575 toesas respecto del mar, ó 3668 varas : aquel suelo está mas baxo que el de Guancavelica 857 varas; y el rio de Iscuchaca, en su quebrada, ha profundizado toda esta cantidad; pero el de Guancavelica entra en él, y. en el parage en donde se hace la union, está mucho mas baxo que en Iscuchaca : con que allí la excavacion de las aguas ha sido desde lo alto del cerro de la $\mathrm{Mi}$ na $1769 \frac{2}{3}$ varas, y ademas todo lo que se halla mas baxo que en Iscuchaca.

I 4 El terreno ó planicie, en donde está el pueblo de aquel nombre, es mas alto que las aguas del rio, quando estas se hallan en sualtura regular de Io á 12 varas, siendo desiguál en extension, como despues se dirá : con que las aguas han hecho esta segunda excavacion sucesivamente, hallándose sobradas señales de ello, y lo son el que por la parte que está cercana al cauce del rio, se halla la misma peñasquería suelta que hay en aquel, no dexando duda que corriéron por su nivel en otros tiempos, y que á fuerza de desmembrar las partes del suelo, lo han ido profundizando.

I5 Como abundan aquellos territorios de rios, no habiendo abertura de tierras ó de montañas por donde no corra alguno, sucede que en los parages en donde hacen union, la llanada de su cauce es mas dilatada que en los otros; porque el cerro ó eminencia que se halla en él con curso, parece haberse disminuido en la parte donde habia de formar la punta, á efecto de 
de lo que las aguas han ido robándole por uno y otro lado, á medida que le han profundizado. Estas llanuras están en forma de graderías, unas mas altas que otras, como que se fuéron disponiendo con casualidad, á medida que las quebradas fuéron haciéndose mas profundas. Al contrario sucede en las partes donde los rios llevan el curso algo derecho, que quasi no tienen extension las orillas altas; y siendo en estas en donde los caminos se hallan cortados, en el poco declive de las pendientes, son muy estrechos y peligrosos, pues apénas tienen la anchura precisa para que pueda sentar los pies un animal. En donde el rio hace vuelta tiene mas capacidad la llanura de la orilla alta, pero no tanta como en donde hay union de rios; y es la causa, porque al dar vuelta las aguas se esplayan mas que quando van línea derecha, y comen la punta de las eminencias por el lado que rodean ó que hace como centro á la vuelta que toman.

I6 De lo que queda dicho se puede colegir toda la elevacion que tiene la parte alta ó serranía de la América resfecto de la baxa; y que en ella misma hay parages profundos, á modo de senos, que tienen, como se ha explicado, I $769 \frac{2}{3}$ varas perpendicularmente, y mucho mas con extension suficiente para poblaciones y sembrados de muchas especies, pero se halla entrecortada con estas aberturas ó quebradas disformes, unas mas profundas y anchas que otras: debiendo entenderse, que á initacion de lo que queda explicado, es toda aquella paite del mundo que se particulariza en ello.

I 7 Para el asunto presente es indiferente que aquellas grandes quebrałas ó aberturas sean la obra de los rios, ó formadas por otra causa: lo que se intenta explicar es, que al respecto de la inucha elevacion que tiene aquella tierra, son mas profundas y mas anchas; no siendo comparables con ellas las de las otras mon- 
el Golfo de Honduras; pero los parages a donde concluyen, hasta las orillas del mar, el territorio es baxo en bastante distancia, en partes anegadizo, y en otras con alguna mas elevacion, que les liberta de ello; pero generalmente los de las cercanías de los rios caudalosos, como el Orinoco, Madalena, Sinú, Chocó, y los demas, las llanadas tienen mas leguas de extension, y sus orillas enpiezan por ser tierra muy baxa, que en algunos se mantiene mas que en otros, sin salir de aquel nivel: no faltan Naturalistas que piensen que los rios caudalosos van extendiendo la tierra con el limo, y las otras materias que arrastran, depositándolas en las orillas del mar por su desembocadura, y que alejan el mar de las orillas antiguas; originándose de esto, que la parte mas inmediata á él es la mas baxa, y que entrando algunas leguas á lo interior, va levantándose el nivel alguna cosa. Otros han pensado diversamente; pero de qualquier modo que suceda, es constante que los grandes rios de aquella parte, ántes de salir al mar corren grandes distancias por parages muy llanos, y que en las inmediaciones á él son tan baxos, que luego que crecen los cubren enteramente con sus aguas.

20 Otro tanto sucede por la parte del Oriente de aquella América, desde el Orinoco, hasta el rio de la Plata; y así la parte alta, de que se habla, está rodeada de una faxa de territorios baxos, los que por este último lado aun tienen mas anchura que por el Occidente, pues corresponden á él las Pampas de Bucnos Ayres, que son dilatadísimas, y las del Paraguay y el Tucuman; pero como estos paises se hallan distantes del mar, no se inundan, y su nivel es de alguna mas altura.

2 I La isla de Curazao, que ocupan los Holandeses, es alta, al modo de un pan de azúcar: la de Jamayca es de serranía bien elevada; y estando cerca de 


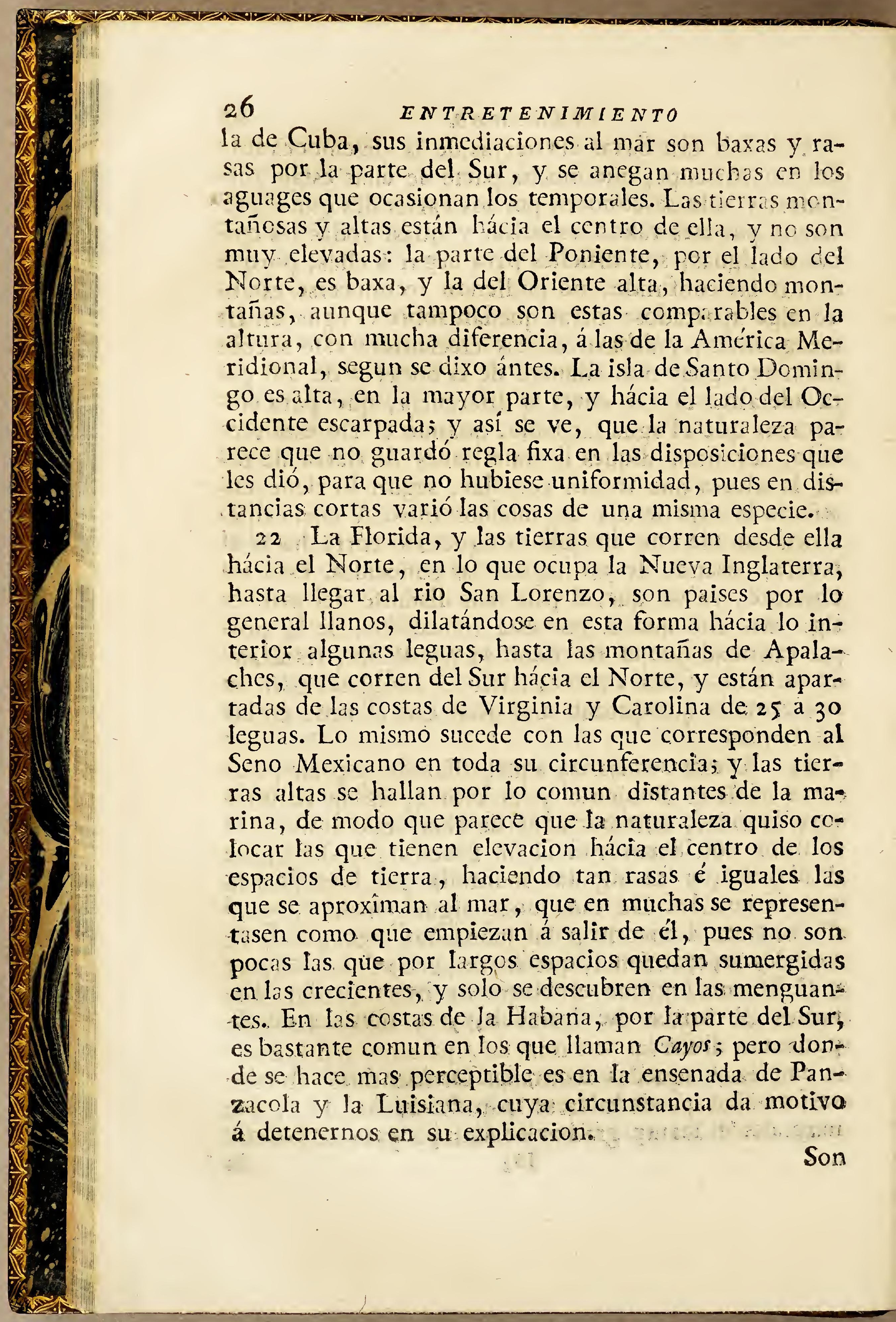


23 Son tan baxas los tierras de la desembocadura del rio Misisipi, que mucha parte de ellas están anegadas, y solo se conocen por los carrizales que scbresalen: por esta razon aquellas, y quasi todas las costas contiguas, son difíciles para llegar a ellas, porque el mar las confunde, no pudiendo reconocerse estando algo apartados: otras quedan sobre el agua en las menguantes, y debaxo en las crecientes: esto sucede hasta is leguas mas adentro de la boca; y de allí para adelante es tan corta la diferencia, que para embarazar que el agua las bañe, quando el rio está crecido, levantan diques ó murallones de tierra de toda la altura que toman aquellas, segun lo tiene enseñado la experiencia de muchos años. A corta diferencia sucede esto en quanto aquel rio corre hácia el Norte, pasando de 550 leguas las conocidas. Esto no obstante, se ve que el pais mas distante del mar es algo mas alto que el que está inmediato; de la propia cantidad que el rio tiene su pendiente, resultando de ello no ser tan ordinario el anegarse; pero es poca cosa lo que quedan mas altas que el agua en las crecientes.

24 A esta semejanza aquel dilatado espacio, que corre hácia el Poniente y el Norte, es de llanuras muy grandes, entrecortadas de rios, que juntándose unos con otros van al fin á descargar las aguas al Misisipi, y de algunas montañas salpicadas en la larga extension. De este modo siguen hasta ir muy al Poniente á encontrar las montañas elevadas de la América Septentrional, que corresponden hácia el mar de California, y por el Norte de esta; siendo centenares de leguas de tierras baxas y llanas 1 s que se cuentan desde las serranías de A palaches hasta donde empiezan aquellas montañas Occidentales: en esta conformidad puede mirarse la parte de América, que corre desde los 25 grados de latitud para el Norte,

$\mathrm{D}_{2}$

di- 
dividida en dos partes: la mas dilatada del Sur al Norte, y del Oriente hácia el Occidente, llana en ámbitos espaciosos, muchos de estos de territorio baxo, $y$ dividida por muchos rios, y por montes salpicados; y la otra, que corresponde al mar Occidental de la California alta, de terreno elevado, al modo del de el Perú, siendo esta la que compone los Reynos de Nueva España, Nueva Galicia, y Nueva Vizcaya; y aunque estos son bien anchurosos, no tienen comparacion con la parte que va desde sus pendientes hasta la serranía occidental de los Apalaches, y desde la oriental de esta al Occéano, por las costas de la Nueva Inglaterra.

25 Aquella parte de territorio elevado hácia el mar de California, del qual no se tiene conocimiento para poder hacer juicio de su altura sobre el nivel del mar, ni tampoco de lo que se extiende en lo ancho de Oriente á Occidente, es la continuacion de la América Meridional, que despues de haberla ocupado en su medianía desde el Sur hácia el Norte, hasta cerca de las costas de Caracas, Santa Marta, y parte del Dariél, se comprimen: pasan por el Reyno de Tierra Firme é Ismo de Panamá, en donde van reducidas á una cordillera estrecha, y no muy alta; y despues, siguiendo por la Provincia de Goatemala, vuelven á extenderse, y tomar elevacion, continuando así por las Provincias de los Reynos de Nueva España, hasta perderse en los paises del Norte de aquella América, que están desconocidos por no haber llegado á ellos los descubrimientos. 26. En esta. América domina mas las llanuras y territorios baxos que las tierras elevadas, lo que no sucede en la Meridional, no obstante de las muchas que tiene desde Buenos Ayres hasta el Tucumán, y por la parte de los rios Grande Marañon, Orinoco, y otros que son caudalosos, y de bastante anchu- 


\section{SEGUNDO.}

chura, pues las tierras altas se extienden todo lo que se ha dicho, y ocupan la parte interior y centro de aquel dilatado espacio de mundo.

27 El rio Misisipi no tiene conocido orígen, ni se sabe el curso que trae hasta los 43 grados; pero por las relaciones de las naciones de Indios, que habitan aquellos territorios mas interiores, se deduce que viene de las partes de Occidente, y que nace en las cordilleras de montañas, que corresponden hácia el mar, mas arriba de California, cuyos paises, aunque son continente con los Reynos de Nueva España, no se han reconocido bastantemente, y así son confusas las noticias que se han adquirido en este asunto. Se ofrece una reflexion bastante curiosa, y es, que en el Perú los parages á donde ménos se ha internado el empeño de los descubridores, son los paises llanos que hay desde las fâldas orientales de la cordillera hácia el Occéano; porque entre ellas y los del Brasil hay territorios muy extendidos, que se mantienen en el primitivo estado que les dió la naturaleza, habitados de Indios, tan incultos y distantes de la civilidad, que viven como las fieras, y solo se diferencian de ellas en la figura. En la América Septentrional son conocidos los dilatados espacios de llanura que corren desde los límites occidentales del Occéano en la Nucva Inglaterra, hasta las montañas de Apalaches, en los que continúan desde èstas hastà el rio Misisipi, y en los que van desde este rio hasta las que forman la cordillera de la parte occidental; pero las otras que corresponden á estas llanuras y á las Provincias de la Nueva Inglaterra, hasta la latitud del Canadá, se hallan tan desconocidas como las lla nuras del Perú entre los rios Orinoco y Marañon; entre este y el rio Grande, y siguiendo hasta Buenos Ayres y el Sur; no encontrándose mas motivo para lo uno que para lo otro; porque 
que si en la Septentrional se quisiere atribuir á lo frígido de aquellas montañas, por hallarse desde los 37 grados hasta los 45 ; en la Meridional los ámbitos desconocidos corren desde las inmediaciones de la Equinocial hasta Buenos Ayres y Estrecho de Magallanes; y no ofreciéndose el impedimento de lo frígido, ni el de lo áspero y escabroso de las cordilleras, no hay otro que el de no haberse cumplido el término que hay, en todas las cosas, para que se penetre á unos y á otros á fin que se conozcan.

28 Las cordilleras de los Andes, en la Améríca Meridional, estaban habitadas por gentes cultas, y segun sus leyes y costumbres civilizadas; por esto se entró en ellas, y se conquistáron con facilidad. Las llanuras que deste aquel mundo alto corren hase ta el Brasil, lo están por naciones bárbaras y feroces, que no conocen ningun género de civilidad, $y$, por esto ha sido dificil introducirse en ellas, establecer algun trato sociable, y llegar á conocer lo que son. Esto mismo sucede en las montañas de la Septentrional, y permanecerán así unas y otras, hasta que corriendo mas el tiempo se vayan insensiblemente abriendo caminos por donde se facilite la comunicacion, y se venga á saber con certeza lo que contienen en calidad de gentes, de animales, de plant $s$; $y$ de otras cosas particulares, que no sean comunes á las demas partes del mundo.

29 Debaxo de las aguas parece que el suelo ó fondo de ellas imita en lo llano y en las desigualdades la disposicion que tienen las tierras que se hallan fuera de ellas; y así en aquellas partes, donde los territorios son muy rasos, baxos, y que siguen con igualdad larges espacios, los que estén contiguos á ellos debaxo del agua son en la misma forma; y esto es á lo que en la Náutica se llama Sonda, porque en bastante distancia de la tierra visible, ó superior 
rior á las aguas, se encuentra el suelo ó fondo $3^{\mathbf{I}}$ cantidad de agua se va disminuyendo poco á poco hasta la orilla. Así se experimenta en las costas de la Florida, en la ensenada de Panzacola, y en todo lo que se conoce con el nombre de Seno Mexicano, que comprehende las costas de Campeche, hasta las de Honduras. No es así en donde hay tierras elevadas inmediatas al mar, ó poco distantes, porque en sus orillas se halla mucha profundidad, $y$ así en las del mar del Sur no se encuentra sonda, siendo preciso estar á la vista de tiera, y algo cerca para hallar el fondo. Las llanuras del fondo del mar son tan iguales como las de la tierra, enseñándolo así los Placeres, que son parages donde hay poca profundidad: el de la Vívora se atraviesa por la parte del Oeste del Cascavel, y se andan sobre él r 2 leguas del Sur al Norte, siendo tal la igualdad del suelo, que en esta distancia no baxa de I 2 brazas, ni llega á completar 13; pero luego que se sale de él se conoce, y se aumenta de repente la profundidad en tanto gra do, que no se encuentra el fondo con 50 brazas. De esto puede colegirse, que si las aguas baxasen de toda la cantidad que lo cubren, se descubriria una llanada, que tendria de largo del Norte hácia el Sur las i 3 leguas que se han dicho, pero esta se hallaria. al modo de las tierras altas de la América Meridional, en lo alto de unas eminencias, respecto de las profundidades que la rodean.

30 Navegando desde la Trinidad al Batabano se hace la mayor parte de este camiıo por Placer de poca profundidad, por cuya causa solo pueden ir por allí embarcaciones pequeñas. Entre las varias profundidades que se ven en él, hay un tramo que llaman el Quebrado de Cayo. Cacao, sobre el qual solo hay if pies: las embarcaciones que necesitan agua de este van arrastrando la guilla sobre él; y si no fuese tan igual

no 
$3^{2}$

ENTRETENIMIENTO

no sería practicable, porque habiendo de hacer camino por espacio de hora y quarto, quedarian estancadas si hubiese en su distancia algunas desigualdades donde el agua disminuyese: en sus inmediaciones es la profundidad desde 12 hasta 20 pies, y sin aumento siguen así distancias de 3 ó 4 leguas. $A$ la semejanza de estas llanuras, que están debaxo del mar, son las de la misma isla de la Habana, hallándose tan iguales, que se anegan con las lluvias, por no tener pendiente alguna para que corran las aguas.

3I De las alturas y llanadas dilatadas que hay sobre las tierras altas de la América, ó de aquel mundo empinado, se ha venido con la idea á dar una noticia de las que están cubiertas de un piélago dilatadísimo de aguas, para que se admire la providencia del Autor supremo en el órden de semejanza que guardó en ciertas cosas, al paso que en otras quiso que no se pareciesen, y tambien que la variedad no fuese regla fixa que hubiese de prevalecer en todo.

EN- 


\section{ENTRETENIMIENTO III.}

Se explican los temperamentos y climas de los diversos territorios de aquellas partes del mundo.

I $\mathbb{E}_{\text {n el conjunto de partes que constituyen es- }}$ te globo, era consiguiente que se correspondiesen unas á otras, y que la variedad fuese participable á cada una de ellas. Así se observa en los temperamentos, que en sus desigualdades imitan las que tiene la tierra. Los ardores de la Zona Tórrida Meridional se encuentran en ella, pero no en todos parages; y se reconocen tambien en la templada en la estacion del estío. Los frios y hielos de esta en lo rígido de los inviernos, son naturales en ella, $y_{\text {; }}$ sin parecerlo, en la calurosa se experimentan tan excesivos como donde mas incomodan: no solamente se hacen naturales allí, sino que á imitacion de aquellas partes en donde por el retiro del sol son ménos extraños los efectos de la frialdad, se ven continuados, con corta intermision, entre las dos estaciones mas opuestas. Los tiempos siguen ordinariamente la regla de los rayos del sol; y por esta causa en aquellos parages, en donde hieren mas perpendicularmente, se impregna la tierra de mas partículas ígneas: Ia reflexîon es mas sensible quanto es mas cficaz, y quanto los rayos reflexos están mas próximos á ser coincidentes con los de inflexîn: de donde dimana, que la impresion que hacen sobre los cuerpos es mas fuerte, y se dexa sentir mas el calor, incomodando á proporcion que es mas grande. La varia direccion de los rayos, mas obliqua, ó mas cercana á la perpendicular, causa las divisiones del año, $\mathrm{E}$ se- 


\section{4}

ENTRETENIMIENTO

segun todos saben: por esta regla, tan generalmente recibida, el calor deberia ser mayor que en ninguna otra parte en los paises que están debaxo de la Equinocial. Así se creyó en lo antiguo, y que á este respecto sería mas sensible en los que están cerca de ella, que en los que se van apartando; pero no sucede así, porque hay otras causas que interrumpen esta regla, que sería segura si las circunstancias fuesen iguales en todas partes; pero como no sucede así, dimana de cllo que en algunas partes cercanas á la Equinocial, y baxo de ella misma, se experimenta un clima frigídísimo, como en el de las Zonas templadas en las proxîmidades de las frias; y por la contraria, en los extremos de la Zona Tórrida y en la templada hay otros parages en donde los calores son tan incómodos como en los que mas molestan cerca de la Equinocial, y en clla misma.

2 La primer causa del calor es sin dificultad la actividad de los rayos del sol sobre la superficie de este globo ; pero luego hay otras causales, que pueden llamarse secundarias, las quales lo modifican, interrumpen todo el efecto, y ocasionan contrarias influencias. Una nube interpuesta entre el sol y una parte de la tierra, es un pabellon que, no dexando tránsito á sus rayos, estorba que pasen hasta ella; y debiendo ser caluroso con exceso aquel espacio, lo es con moderacion, tanto mas, quanto la nube fuere mas permanente. La elevacion de un parage respecto de otro, hace el ayre mas sutil y ménos pesado: los rayos del sol, subdivididos en partículas mas menudas que quando la atmósfera es densa, reflexan con la misma sutileza, y no tienen lugar para unirse: siendo conseqüiente, que el grado de calor debe ser ménos que quando penetran por un ayre mas pesado y denso, el qual une las partículas ígneas, se impregna de ellas, y las reflecta con 
mas actividad. En los lugares elevados, por lo comun, no falta algun movimiento en el ayre, que en los baxos, por el contrario, no es tan comun, y este esparce las partículas ígneas en diferente direccion de la que llevan en la inflexion de los rayos, y con la que retroceden en la reflexion. La elevacion de los parages y sus desigualdades no permiten que el número de rayos que caen sobre ella sea tan crecido como en el nivel general del globo; y esta es otra causa que altera su efecto para el demasiado calor.

3 A las razones antecedentes, que se hallan sostenidas con la experiencia, se agrega otra muy poderosa, y es, que segun los Naturalistas, el ácido nitroso es, de los tres que se conocen en la naturaleza, volátil y muy ligcro, atribuyéndose á su concurso la formacion de la nieve, el granizo y el hielo, lo qual sucede en una region algo elevada de la atmósfera: quanto los territorios estuviesen mas altos en ella, tanto mas cercanos se hallarán de esta region, y los efectos serán contrarios al calor: por esto se experimenta que en las cumbres de las montañas altas hay nieve quando en su pié no se ve, y por el contrario se experimenta calor, cuyo fenómeno es tan comun, que no hay pais en donde dexe de verse; y si la montaña se figurase ser de una altura tan excesiva como los terrenos altos de la América Meridional, y de la extension que tienen aquellos, se comprehenderia mejor ser natural en ellos, aunque se hallan debaxo de la Equinocial, ó en sus cercanías, lo mismo que en las montañas de la Europa: con la diferencia de que lo que acá se experimenta en una altura de I 500 ó 2000 varas, allá necesita que sea de 4 ó 5000 , ó tal vez mas, segun las otras circunstancias que concurren en él.

4 Por estos términos la naturaleza ha formado $\mathrm{E}_{2}$

un 
TERCERO.

gas el frio excesivo ocasiona tanto el escorbuto 37 mo el calor; y que esta enfermedad no es tan temible al pasar por la Línea, quando no hace mucho tiempo que se ha salido del puerto, como quando se navega por parage muy frio, como el Cabo de Hornos, ó el de Buena Esperanza, despues de haber estado largo tiempo en el mar sin refrescar los víveres en algun puerto, y reponer la naturaleza en su estado natural con los ayres propicios de tierra.

6 En el mar del Sur se atraviesa freqüentemente la Línea, pasando del Callao ó de Guayaquil á Panamá, y al contrario, sin experimentarse efecto alguno perjudicial á la salud; y es sin duda por ser de cortos dias estas travesías: siendo natural, que si fuesen largas sucedería lo mismo que en las otras en donde hace destrozos lastimosos contra los navegantes; y así parece que no deben atribuirse tanto al demasiado calor, que se supone, como á las otras causas que son inseparables en los viages largos por el mar.

7 Para comprobacion de no ser el calor baxo de la Línea en el mar tan grande como en los parages que están fuera de ella, se hará relacion de los que se han observado en varias partes, cuya noticia podia servir de convencimiento. El año de 1758 , cortando la Equinocial, segun la frase que se acostumbra en la Náutica, en el mes que el sol debia hacer tcdo el efecto de sus ardores, por ser en Marzo quando hace su tránsito por ella, el dia 3 , teniendo de declinacion meridional 6 grados, $42 \mathrm{mi}$ nutos, y estando la cmbarcacion en 7 grados, 47 minutos septentrional, el termómetro de Mr. d'Reaumur señaló á las 2 de la tarde 20 grados 2 de calor. Desde este grado fué aumentando poca cosa. El dia I4 la declinacion meridional cra 2 grados, 25 minutos: la cmbarcacion se hallaba en 3 I minutos 
de i grados, empezó á disminuir á $23 \frac{x}{2}$, y con la misma lentitud que habia aumentado volvió á ser ménos.

Io En el mes de Noviembre de 1764, atravesando la Equinocial en el mar del Sur el dia 28 , la embarcacion se hallaba en 52 minutos Sur: á las 5 de la mañana el mismo termómetro marcaba 2 I grados, á las 2 de la tarde $23 \frac{x}{2}$, y á las í de la noche $22 \frac{\pi}{2}$ : el : viento vário, floxo por el Sur, Sueste y. Sudueste : la atmósfera opáca mucha parte del dia.

I I El dia 29 del mismo, á las 5 de la mañana, señalaba el referido termómetro 22 grados; á las 2 de la tarde 24 , y á las I I de la noche $23 \frac{x}{2}$ : el viento y la atmósfera lo mismo que en el dia antecedente : la latitud 35 minutos Septentrionai; de suerte que en el intermedio de un dia al otro se hizo la travesía de la Línea.

I2 Por este término se mantubo el calor todo lo que duró el viage hasta Panamá, sin exceder á las 2 de la tarde de 23 grados, y á las 5 de la mañana de $2 \mathrm{I}$, siendo su mayor alteracion con las calmas y el tiempo cargado un grado, en cuya disposicion duraba poco.

I 3 En Panamá no señaló el termómetro mas calor que en el mar y en el tránsito de la Línea. Desde el dia 4 de Diciembre hasta el I8, á las 5 de la mañana, marcaba 2 I grados, á las 3 de la tarde $23 \frac{x}{2}$, y uno ú otro dia llegó á subir hasta 24. En aquella ocasion es quando cesan los vientos Sures, y empiezan á recalar algo las brizas; pero esto no sucede todos los dias, ni en todos los años es en un propio tiempo, aconteciendo que en unos se adelantan mas, y en otros se retardan: en aquel se adelantáron, y desde el dia 8 hasta el I 2 recaló á las 2 de la tarde: el I 3 fué floxa, y el termómetro estubo en 24: el i 4 no la hubo, y estubo en $24 \frac{1}{2}$ : el Is la hubo, y el termómetro estubo en 23 . En esta for - 


\section{TERCERO.}

mente el termómetro marcaba á las 6 de la mañana 22 grados, á las $\mathbf{2}$ del dia 24 , y á las 2 de la tarde $24 \frac{x}{2}$. El año de 35 , el 19 de Noviembre, tiempo en que las brizas no estaban entabladas, el termómetro marcaba de 24 á 26 grados, que en rigor es grado y medio mas que lo que se observó en el último. La latitud de aquella ciudad es, por las observaciones, Io grados, $25 \frac{3}{4}$ minutos Septentrional.

I 7 No se hace mencion por ahora del temperamento de Lima, cuya ciudad está en 12 grados, $2 \frac{r}{2}$ minutos en el emisferio Austral, porque aquel sigue otro régimen distinto del de las partes de que se va tratando, y se irá desde luego á ver el de la Habana, en las extremidades de la. Zona Tórrida, y vecindad de la templada. En este parage se encontrará un efecto contrario al órden que se debia esperar. En algun modo sería regular que en la $\mathrm{Haba-}$ na el calor fuese ménos que en los parages que quedan citados, por hallarse mas apartado que ellos de la Equinocial; pero si se atiende al mas tiempo que el sol se mantiene perpendicular en el Zenit, ó inmediato á él, el calor deberá ser mas fuerte que en los lugares que se hallan en la Equinocial, ó cerca de ella; suponiéndose igualdad en altura de los terrenos, que es, con toda precision, lo que acredita la experiencia.

I8 El calor de la Habana, en los meses que el sol se halla de la Equinocial para el Norte, es mas fuerte que en Panamá, Portovelo, Cartagena, y que debaxo de la Línea en el mar del Sur; y en el tiempo que corren los 6 signos Australcs, es igual al de aquellos. La ciudad se halla en 23 grados, 10 minutos de latitud Septentrional en una tella dispesicicn de terreno; por el un lado ticne la bahia, por ctro el mar grande, y por el resto pais llano, en el qual, aunque hay algunas eminencias, es á larga distan- 
cia, y no son de mucha altura, con que los vientos la bañan sin embarazo. Las observaciones del temperamento se hiciéron unas allí, y otras en Guanabacoa, lugar que dista dos leguas, y se tiene por mas sano y ménos cáluroso que la ciudad, por estar situado en una mediana altura, donde le bañan los vientos, que templan el calor del sol.

19 El dia 7 de Febrero de 1765 , á las 6 de la mañana, marcaba en la ciudad el termómetro $18 \frac{x}{2}$ gradios, á las I $2 \frac{1}{2} 20$; en la tarde hubo turbonadas de viento, y algunos aguaceros. Así permaneció hasta el dia 19, que fué mayor el calor; á las 6 de la mañana estubo en 20 grados, y á las I 2 del dia en $22 \frac{x}{2}$ : de las 3 de la tarde á las 4 mudó el tiempo con aguaceros, y calmó el viento: á las 5 empezó á correr por el Norte, y refrescó el tiempo, de suerte, que en el siguiente dia 20 , á las 6 de la mañana, estaba en 17 grados, continuando sin aumento el resto del dia, y en los dos siguientes.

20 El verano fuerte empieza allí en Mayo: en aquel mes, á las 5 de la mañana, el termómetro señalaba $22 \frac{\mathrm{T}}{2}$ grados, á las $\mathrm{I} 2$ del dia $25 \frac{\mathrm{x}}{2}$, y á las I I de la noche $22 \frac{x}{2}$. En. Junio 23 grados, $26 \frac{x}{2}, y$ : á las I I de la noche $23 \frac{x}{2}$. En Agosto y Septiembre sucedió lo mismo. En Octubre se reconoce algo moderado el calor, por no mantenerse constante el termómetro; pero no por eso faltan dias en que se ve el licor hasta 25 grados, siendo lo regular de $23 \frac{x}{2}$ á 24. En Noviembre es lo regular á las 2 de la tarde desde 2 I $\frac{I}{2}$ á $23 \frac{I}{2}$. Esto propio sucede en Diciembre y Enero, que son los meses del invierno, en los quales se dice, que se siente frio; con que la diferencia entre estas dos estaciones es de 3 grados. Debe entenderse, que este grado de calor en todos tiempos es, situando el termómetro en alguna pieza abierta, donde reciba las impresiones del ayre, sin que 
el resplandor del sol le hiera, pues quando se coloca en parage donde participe de él, se dilata el licor hasta $30 \frac{T}{2}$ grados.

2 I En los meses de invierno siempre vienen los vientos del Norte, se comprime el licor, y es quando se siente mas frescura. En los de verano, aunque llueva, como sucede de continuo, no se modera el calor, porque de ordinario sobreviene á la lluvia algun intervalo de calma, y despues vuelven los vientos á la parte del Sur, que son calurosos. No es lo particular el grado en que asciende el licor del termómetro, sino la permanencia que tiene en él, y lo poco que varía de una estacion á la otra, pues en la Zona templada, y bien al Norte de ella sube á los mismos grados; pero esto es por espacio de un mes, ó poco-mas, en algunos dias, y despues vuelve á descender por los mismos términos que fué subiendo. En Diciembre, quando el sol está en el Trópico de Capricornio, dista del Zenit de la Habana 47 grados, lo mismo que dista del de las partes meridionales de la España. En 20 de Octubre, acabado de pasar el verano; y en 20 de Febrero, quando va terminando el invierno, en el primero de estos dos tiempos el termómetro, á las 6 de la mañana, señala en Cadiz $14 \frac{x}{2}$ grados, á las 2 de la tarde $16 \frac{x}{2}$, y á las II de la noche de 15 á I 6 . En el segundo, á las 6 de la mañana, señala de I 2 á I 3 grados, á las 2 de la tarde de 14 á 15 , y á las II de la noche de I 3 á I4; y así hay de 8 á 9 grados ménos calor que allá quando el sol dista del Zenit el propio número de grados, segun queda explicado. Por estas experiencias se reconoce, que aunque la $\mathrm{Haba-}$ na está distante de la Equinocial todo lo que el Trópico, esto no es suficiente causa para que el calor se experimente ménos fuerte que en los lugares que están cercanos á ella, guardando igualdad en quan- 
44 ENTRETENIMIENTO

to á la forma de los terrenos, porque, en las partes que quedan anotadas, son baxos, llanos, é inmediatos al mar.

22. La causa de esto es, como queda dicho, la direccion perpendicular de los rayos del sol, que en la Habana es mas permanente que en los otros parages que se hallan mas cerca de la Equinocial, porque el movimiento del sol en declinacion es lento quando se acerca á los Trópicos, y acelerado quando está inmediato á su medianía; y por esto permanece mucho mas tiempo en las cercanías del Zenit de aquella ciudad, que en la de los otros parages; á cuyo respecto calienta mas la tierra, y la penetra con mas actividad que en donde pasa acelerado sin detenerse. Desde el 2 I de Junio hasta el 12 de Julio está el sol sobre el Zenit de la Habana, á diferencia de un grado: este intervalo es de 22 dias; pero en las dos estaciones, que pasa por el de Panamá en Abril y en Agosto, solo está I I, $5 \frac{r}{2}$ en cada una, esto es, desde que se acerca el grado inmediato, ántes de llegar, y despues de haber pasado por él, con que viene á ser la mitad del tiempo; sucediendo esto con la intermision de 6 meses, en la qual se ha temperado el calor que se imprimió en la tierra en los $5 \frac{1}{2}$ dias primeros al repetirse los segundos: con que aun es ménos de la mitad de la influencia la que recibe el territorio de Panamá de la que percibe el dé la Habana, en donde los 22 dias son continuos. Para la mejor inteligencia se ha de suponer, que un grado de calor igual, repetido en varios dias en la tierra que lo recibe, se aumenta en cada uno de ellos mas de lo que fué en el antecedente, porque como la encuentra impregnada de las partículas ígneas que recibió en las anteriores, quanto mas se repita el grado de calor, tanta mos disposicion encuentra en ella para conservarle.

Otro 
TERCERO.

23 Otro exemplar convencerá mas esta razon. Supóngase que la actividad sensible de los rayos del sol se experimenta dentro del espacio de ro grados ántes de llegar el sol al Zenit, y hasta volverse á apartar de él la misma cantidad: desde 20 de Abril empieza el sol á entrar en los ro grados próximos al Zenit de la Habana; y hasta el 2 I de Agosto no sale de ellos, siendo quatro meses continuos. En el primer tránsito, por el Zenit de Panamá, está desde 29 de Julio hasta 20 de Septiempre, que es un mes y 2 I dias: en el segundo, viniendo del emisferio Austral, desde 20 de Marzo hasta ro de Mayo, que son otro mes y 20 dias; y ambos tránsitos componen 3 meses y I I dias: así está 20 dias mas dentro del espacio de los ro grados inmediatos al Zenit en el de la Habana, que en el de Panamá, siendo estos últimos interrumpidos de 2 meses y Io dias, corriendo el sol signos Septentrionales; y de 6 meses, con corta diferencia, quando anda por los del emisferio Meridional; con que por precision el calor ha de ser mas sensible en la Habana, estando quasi en el 'Trópico, que fuera de allí en los parages que están cercanos á la Equinocial; y los efectos de la Zona Tórrida deben ser, y son mas perceptibles en aquel que en estos otros.

24 Para perder la tierra el calor que ha percibido por espacio de quatro meses continuos, necesita mucho mas tiempo que si estos quatro meses hubiesen sido interrumpidos de un espacio de tiempo en que el sol hubiese estado mas apartado del Zenit que los ro grados; y por esta causa, aun despues de estar fuera de ellos, permanece el calor, que es lo que se ve en Septiembre y muchos dias de Octubre, en cuyo tiempo el grado es el mismo que quando está dentro de los io grados próximos al Zenit. Se siente allí el efecto que hacen los rayos directos ó

per- 
TERCERO.

perar la tierra y el ayre en la noche, respecto del otro parage, cuyos efectos son sensibles.

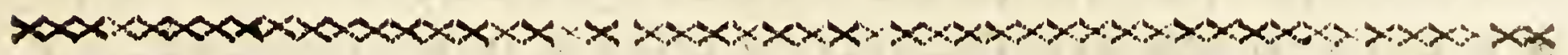

\section{ENTRETENIMIENTO IV.}

\section{Continua sobre los varios temperamentos.}

I Lia variedad que se observa en los temperamentos, sin sujetarse precisamente á la regla de lo mas ó ménos apartados que se hallan los territorios de la Equinocial, no sería persuasible si la experiencia no lo convenciese. La Provincia de la Luisiana es una de las que mas se distinguen en ello, pues que hallándose en 30 grados y minutos de latitud su capital el Nuevo Orleans, los calores de los quatro meses de verano, desde Junio hasta Septiembre, son mas fuertes que en la Habana, y que en los otros parages que están mas cerca de la Equinocial: á este respecto, en los meses de invierno se alternan los frios y los calores con tanta repeticion, que despues de tres ó quatro dias de fuertes hielos siguen otros en que el calor es poco ménos que en los regulares del verano; pero aun mas extraordinario es que con el mismo viento que hiela en el invierno se experimenta en el verano el mayor calor. Estas variedades, que no son regulares en otras partes, hacen particular aquella, y parece, contra lo natural, que en el rigor del invierno, quando reynan las nieves y los hielos, se vean alternados dias calurosos, como si los rayos del sol cayesen directos sobre aquella region. Los vientos están allí en continuado giro, siendo raro que permanecen dos dias por la misma parte. En el invierno llueve con 
los del Sueste y Sur; y en la misma hora que cesa de llover hace la vuelta al Norte, y empieza el frio: quando sucede que se detiene en esta parte mas de un dia, y que aumenta de fuerza, es seguro que hiele; pero quando sigue la vuelta sin permanecer, $y$ que llega á pasar del Norte al Levante, aunque sea cosa muy corta, el frio no es grande: siendo cosa cierta, que no ha de durar constante, y que pasando prontamente al Levante, y de allí al Sur y Sudueste, se repite la lluvia y la nieve, y vuelve á hacer nuevo giro como el primero.

2 Los vientos del Noroeste y Norte son los que allí causan el frio en el invierno, hasta el término de helar fuerte. Estos mismos vientos ocasionan el mayor calor en verano, hasta términos de sofocacion; pues es tal, que si su duracion pasase de dos ó tres dias, moriria mucha gente de no poderla resistir. La razon de los frios que causan en el invierno estos vientos, es la misma que se conoce en todo el emisferio Septentrional; pero no hay otra para el calor que el venir de aquellas dilatadas llinuras, de los bosques espesos, y pajonales dilatadísimos, los quales, con la humedad y el calor intenso de los rayos del sol, exhalan vapores ardientes; y adquiriendo el ayre su misma qualidad, en lugar de refrigerar, sofoca en tanto grado, que es mas sensible este ayre que el calor que se siente quando hace calma.

3 Para el convencimiento de estas sensibles desigualdades, será bien conjeturarlas con las observaciones hechas en el termómetro. Los dias de mas cafor en el Nuevo Orleans el año de 67 fuéron el I2, 13 y 14 de Agosto. El primero de estos, á las 5 de la mañana, el termómetro señalaba dentro de una sala, que estaba rodeada de ventanas y puertas, todas abiertas, $23 \frac{x}{2}$ grados, y expuesto al ayre al 
QUARTO.

resguiardo de una galeria espaciosa y cubierta $22 \frac{4}{2}$ á las 3 de la tarde en la sala 27 , y fuera $32 ;$ á las I2 de la noche dentro $26 \frac{x}{2}$, y fuera 26 : todo el discurso del dia y noche estubo claro: por la mañana no habia viento: á las 3 lo hubo fioxo Oessudueste, y en la noche Oesnoroeste.

4 El dia $\mathrm{r}_{3}$, á las 5 de la mañana, 24 dentro, y lo mismo fuera: á las $2 \frac{x}{2}$ de la tarde, dentro $27 \frac{4}{5}$, y fuera $33 \frac{3}{4}$ : á las $3 \frac{x}{2}$ de la tarde 28 y $32 \frac{x}{2}$ : á las $528 \frac{3}{4}$ y $32 \frac{\mathrm{r}}{2}$ : á las $\mathrm{I}_{2}$ de la noche $27 \frac{\mathrm{I}}{3}$ fuera, é igual dentro: el viento era floxo Norte.

5 El dia 14 , á las 5 de la mañana, estaba en la sala en $25 \frac{1}{2}$, en la galería abierta 25 , la atmósfera clara, el viento floxo Norte: en las siguientes horas del dia como se ve:

A las 9 en la sala $26 \frac{T}{4}$.galería $30 \frac{x}{2}$. A las s de la mañana el baróá la I delante..... $27 \frac{\mathrm{T}}{2} \ldots \ldots . . . . .32 \frac{\mathrm{r}}{2}$. metro estaba en 27 pulgadas, álas $3 \frac{r}{2} \ldots . . . .0 .28 \frac{r}{2}$

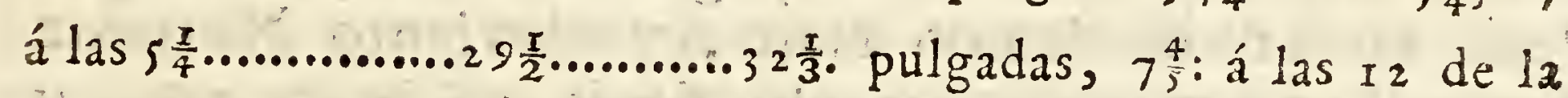
álas 2 de la noche $27 \frac{x}{2} \ldots \ldots . . . . . .28$. noche 27 pulgadas, $7 \frac{2}{3}$ líneas.

Desde las 9 del dia con la fuerza del calor cesó el viento, y solo á ratos se experimentáron ventolinas del Norte por la parte del Este: la atmósfera estaba ofuscada, y en la noche hubo algunos relámpagos, efecto propio del mucho calor.

6 El siguiente dia Is se experimentáron al amanecer los efectos que habia dexado en la atmósfera el calor del dia antecedente; y á las 5 de la mañana estaban por conseqüencia los termómetros en 26 grados mas altos que en igual hora el dia antecedente, lo qual anunciaba mayor calor que en aquel, pero el viento habia ya corrido por el Nordeste al. Esueste; y así á las $4 \frac{x}{2}$ de la tarde, que fué el mayor calor de aquel dia, el termómetro estaba en la saG 
50

la en 27 grados, y en la galería 29; á las I 2 de la noche dentro 24 , y fuera $24 \frac{1}{2}$. El barómetro estubo á la primera hora en 27 pulgadas, $7 \frac{2}{3}$ líneas: en la segunda $8 \frac{1}{3}$ líneas, y en la tercera $9 \frac{1}{2}$ líneas: la atmósfera con algunas nubes altas y rasgadas, y el viento, desde las 5 de la mañana, fué por el Sueste algo recio.

7. Segun el juicio de aquellos naturales, fué el calor de los tres dias mayor que el que se experimenta en años regulares; y en efecto, en los de 66 y 68 no llegó á tanto, y en el último el 18 de Agosto era 26 grados dentro de la sala á las $3 \frac{x}{2}$ de 1 la tarde; y en la galería $30 \frac{1}{3}$ : el viento estaba floxo Noroeste, la atmósfera algo empañada con celages, y el barómetro señalaba 27 pulgadas, I $\frac{1}{4}$ líneas.

8 En el año de 66 se experimentó el mayor calor en los dias 17 , hasta 25 de Julio; pero el mayor fué el $2 \mathrm{I}$, que á las 4 de la tarde el termómetro estabà en la sala en 27 grados, y el de la galería en $3 \mathrm{I}$, el tiempo claro, y el viento Noroeste floxo. Los otros dias se vió desde 26 hasta $26 \frac{2}{3}, \mathrm{y}$. en la galería dêsde 29 hasta $3 \mathrm{I}$, siendo el viento totalmente ninguno, ó por el Noroeste.

9 El verano es allí largo, pues desde mediados de Mayo se experimentan calores recios, subiendo el termómetro en lo pesado del dia á $23 \frac{x}{2}$ grados en la sala, y á 27 en la galería, aunque esto no es en todos. En los dias 7,8 y 9 de Octubre del referido año de 67 , subió en la sala de 24 hasta 25 grados, y expuesto en la galería á 28 y 29 , que es el mayor grado de calor en España; y así dura el verano fuerte cinco meses completos, sin contar los meses que le preceden desde Marzo hasta Mayo, en que empieza á sentirse alguno, y hay dias en que lo hace muy competente; ni contando tampoco desde Ocrubre hasta Noviembre, en que va dexando 
do de ser tan fuerte, para cambiarse, 5 I del invierno.

ro Se sienten allí los efectos de este gran calor por unos modos que no son regulares en otras partes. Caminando en tiempo de verano, despues que el sol se ha puesto, se entra de repente en un clima mucho mas caluroso que por el que se llevaba: dura esto por una distancia de 20 ó 30 pasos, y. con la misma prontitud que se sale de él vuclve á darse en el primero, como si hubiese faxas ó $\mathbb{Z} O$. nas de un temperamento que fuese mas caluroso que el resto, y en el distrito de un quarto de legua suelen experimentarse tres ó quatro de estas mutaciones. La causa de esto no es facil determinarla, aunque puede atribuirse á varios accidentes, porque allí no tienen cabimento las quemazones de los campos despues de recogidas las cosechas, que es lo que suele calentar el ayre mas en aquella parte para donde va que en otras. El territorio es igual en qualidad y forma, y no puede juzgarse que el calor de los rayos del sol se fixe mas en unos ámbitos que en otros. Solo puede tener verosimilitud que en las columnas de ayre, consideradas horizontales, unas quedasen paradas despues de haberse puesto el sol, y otras se moviesen mudando de lugar; y en esta forma, las primeras se sentirian con el calor que tenian quando el sol hería en ellas, y las otras lo perdiesen con el movimiento de un ayre muy floxo que las agitase: con esto conviene la circunstancia de que quando se experimentan estas mutaciones es quando no se percibe viento. Otro efecto raro de los rayos del sol son los que se llaman golpes de él, ó mas propiamente asentarse el sol: allí sucede con tanta fuerza y prontitud, que se quedan muertos los hombres de repente, con señales no equívocas de haber sido la actividad del sol la que les quita la vida. En la gente de $\mathrm{G}_{2}$

tra- 
trabajo, que para hacerlo estín parados en una parte, es en los que mas comummente se ven estas desgracias, y es raro el año en que no se experimente aiguna.

I I Por las observaciones que quedan citadas se comprueba, que aunque el Nuevo Orleans está én algo mas de 30 grados de latitud, y que el sol no llega á estar nunca con diferencia de $6 \frac{x}{2}$ en su Zenit, es el calor en el verano mas fuerte que en la Habana y que en los otros lugares que están cerca de la Equinocial. La razon de esto es la igunlad de aquel pais, y los bosques espesísimos de arboledas altas que hay en él; y siendo por lo general floxos los vicntos en aquella estacion, no les da entrada á los sitios en donde están las poblaciones. A esto se agrega, que hallándose distante del mar, con dificultad penetran hasta ella los que reynan allá, y es muy comun no sentirse ayre en lo riguroso del verano. Si corre del Norte, viene sobre la tierra, atravesando las dilatadas llanuras y bosques, en donde contrae la misma propiedad que tienen los vapores que se levantan de ella, resultando de todo, que contra la regla que parece regular de la mayor distancia del sol al Zenit, en aquel territorio es mas activo que en los que distan ménos, $y$ que se experimenten los raros efectos que quedan referidos.

I2 Aunque en el verano es allí el calor como queda dicho, no sucede como en la Habana, que se concentre tanto en la tierra, durando sus efectos en las partes subterráneas algun tiempo: por el contrario se ve, que las aguas del Misisipi, aunque por arriba están calientes, sacadas de la profundidad se encuentran frias, y en bastante grado; lo qual indica que el calor del sol no puede penetrar hasta lo mas profundo: siendo la que tiene, por el parage de la ciudad, de 20 á 25 brazas, porque aquel es un calor 
lor accidental, aumentado de la falta de viento, $y$ de la calidad de los vapores que cxhalan las arbole. das y tierras himedas, Jos quales se agregan al natural de los rayos del sol.

I 3 En un pais donde el calor llega al grado que alli, y que es de tanta duracion, no pudiera presumirse que en el invicrno, por el contrario, fuesen los frios y hielos tan grandes como se experimentan, que es ctro fenómeno propio únícamente de aquel clima.

I4 El temperamento de Noviembre, por lo regular, es de 17 á i 8 grados á las 6 de la mañana; de I9 á 20 á las 2 de la tarde, y de 17 á i 8 á las I I de la noche. Hay dias que repentinamente baxa 7 ú 8 grados, y con la misma prontitud vuclve subir la misma cantidad en el siguiente. El año de 68 empezó á helar desde el dia 8 de Enero; pero los mas fuertes fuéron en los I7 y I8. En estos el termómetro baxó del término de la congelacion dentro de la sala, cerradas puertas y ventanas, á las 6 de la mañara $2 \frac{x}{2}$ grados; en la galería $7 \frac{x}{2}$ : á las 2 de la tarde subió del término de la congelacion $3 \frac{3}{4}$ : á las i de la noche estubo mas baxo que ella 2 grados; en la galería de 5 á 6: las orillas del $\mathrm{Mi}$ sisipi se heláron de 6 á 8 varas por cada una dentro del rio en agua corriente: es por demas decir que el agua de las vasijas, que estaban dentro de la pieza donde se hallaba el termómetro, se heló enteramente. Los dias ig y 20 heló tambien, pero con moderacion: el 2 I se sintió calor; y el 22 , á las 6 de la mañana, el termómetro en la sala estubo en I 2 grados de calor; en la galería x I $\frac{x}{2}$ : á las 4 de la tarde I $6 \frac{2}{3}$ y I $7 \frac{x}{2}$, y á las II $\frac{x}{2}$ de la noche $15 \frac{x}{2}$ y $14 \frac{1}{2}$; pero el dia 29 subió en la sala á $17 \frac{3}{4} ;$ y en la galería á 2 I $\frac{x}{2}$ : con que en el corto intervalo de tres ó quatro dias se experimentáron los tempe- 
ramentos contrarios de paises frios y cálidos en hielos fuertes y calores sensibles. Estas alternativas de frio y calor son allí muy comunes, aunque no todas tan grandes como la que queda referida, siendo 10 regular entre 8 ó io grados de un dia frio á uno caluroso. Aquel año anunciaban los árboles la primavera en el invierno, porque en fines de Diciembre habian cesado los grandes frios, y hacia calor: se habian vestido de hojas y flores, con particularidad los naranjos; y este adelantamiento que tenian fué su perdicion, porque sobreviniendo los hielos quando estaban en la fuerza de los brotes, los secó, cuyo accidente se suele repetir alli con alguna freqüiencia, por la desigualdad que tiene el temperamento. De esto nace que hasta que pasa el mes de Marzo, y es entrado Abril, no hay seguridad de haber cesado el invierno, no obstante que se experimenten calores de verano.

I5 El año de 66, el dia I4 de Marzo, á las 6 de la mañana, el termómetro estaba en $2 \frac{\pi}{4}$ grados mal alto que la congelacion: el 8 habia estado á la misma hora en $16 \frac{1}{2}$, y el 16 estubo en $16 \frac{2}{3}$; pero el I 7 volvió á estar en $I_{3}$ : el 22 subió á la propia hora á $13 \frac{3}{4}$, de suerte que en el discurso de catorce dias hubo tres veranos y dos inviernos, acaeciendo esta novedad por la variedad de los vientos, frios quando ventaban del Norte, y calurosos quando venian del Sur. Estas alteraciones, que no las alcanza el discurso con la precision que ellas son sin el auxîlio de la experiencia, son mas extraordinarias por causa de no haber montañas en aquellas inmediaciones, $\mathrm{ni}$ en algunos centenares de leguas, y consiguientemente no hay mas nieves que enfrien el ayre que las que caen en aquellas dilatadas llanuras, donde no permanecen, porque luego que los vientos cambian á la parte del Sur, se derriten 
enteramente. La razon de estos frios tan repentinos, 55 y variados con el calor, no puede encontrarse en otra causa que en los hielos de los lagos espaciosos que están hácia la parte del Norte del Misisipi, desde los 42 grados en adelante: estos se hielan, y corriendo los vientos por ellos contraen la frialdad que van á comunicar á la Luisiana: siendo esta la causa, es accidental el frio, experimentándose, quando corren aquellos, contrario á lo que sucede con los del Nordeste, Levante, y partes del Sur, que por ir del mar son calientes.

16 En el corto distrito que hay desde Panamá y. Portovelo hasta la Luisiana, se han visto temperamentos diversos, y que no corresponden á la distancia que tienen de la Equinocial : siendo extraordinario que fuera de la Zona Tórtida, donde los rayos del sol nunca llegan á ser perpendiculares, los calores sean mas activos que en los parages que se hallan con mas inmediacion á ella; y por el contrario mas fuertes los frios que en otros de la Zona templada, en donde deben hacerse sentir con exceso. Ahora toca pasar del emisferio Boreal al Austral para comparar otros temperamentos de la Zona Tórrida con Ios que quedan explicados, reconociendo en ellos, no con poca admiracion, los fenómenos extraños de la naturaleza, que por el contrario, de los extremos en frio y calor que se ven en la Luisiana; contra el órden riguroso de las reglas de los climas, es templado lo que debia ser cálido, y con exceso frio lo que parece que indica efectos del mas insoportable calor.

I7. El temperamento de aquella faxa de terreno baxo, que corre lo largo de la América Meridional en el mar del Sur, está explicado en la obra de Observaciones con la individualidad que pide la materia; pero para comprobacion de aquello, y continuar la 
56

ENTRETENIMIENTO

comparacion que se va haciendo, será conveniente renovar aquí las noticias con las observaciones del termómetro; que siendo siempre el mismo de que se usó en las que van explicadas, será mas segura la conseqüencia que se saque de ellas.

I8 A la parte del Sueste de Lima, y $34 \frac{x}{2}$ leguas de aquella capital, hay un valle bien dilatado, que forman dos colinas de montañas, y es conocido por el nombre de las Capillas; $y$ aunque su latitud no está determinada por observaciones, se puede computar por la de Lima, y á corta diferencia será de I 3 grados. El dia 23 de Octubre del año de 58, á las 6 de la mañana, estando el termómetro expuesto al ayre, marcaba i grados, y á las 2 de la tarde i 8 : debiendo advertirse dos cosas, la primera, que el sol se hallaba quasi en el Zenit de aquel parage, pasando al Trópico de Capricornio: la segunda, ser aquel un valle entre dos colinas de serranía, donde el calor es por lo regular mas intenso que en los parages abiertos; pero estas observaciones harán mas convincente la moderacion de aquellos.

I9 Desde el dia 8 hasta el 23 de Octubre del año de 64, en el lugar de Bella-vista, próxîmo á las ruinas del Callao, el termómetro, puesto á la sombra dentro de una sala espaciosa, marcó constantemente, á las 5 de la mañana, de 15 á I $5 \frac{x}{2}$ grados; y la mayor diferencia en el discurso del dia, era de un grado, que subia en las horas desde las i I á las 2 de la tarde, cuya poca alteracion procedia de que el tiempo era nublado. En los mas de los dias se experimentaban todavia lo que llaman garuas de invierno, que son lluvias menudas, ó mas propiamente niebla, que llega á reunirse, y se precipita: el sol se descubria muy cortos intervalos en el dia, que no pasan de una ó dos horas, volviendo á encubrirse con las nubes, que con igualdad ocupaban todo el ám- 
QUARTO.

ámbito de la atmósfera. En estos ratos que el sol aparecia era quando se sentia aquel poco de mas calor, que en el termómetro causaba là diferencia de un grado, como queda explicado.

20 Desde el 23 de Octubre hasta el 5 de Noviembre aumentó el termómetro un grado, y en lo mas caluroso del dia hasta $2 \frac{x}{2} ;$ de modo, que á las 5 de la mañana estaba en 16 ó $16 \frac{1}{2}$, y á las dos de la tarde subia hasta 18 ó I $8 \frac{1}{2}$, subsistiendo todavía la atmósfera ocupada de nubes altas y contiguas, que tenian cubierto el sol lo mas del dia: solo desde las ro ó $10 \frac{I}{2}$ hasta las $2 \frac{T}{T}$ de la tarde se disipaban, y se sentia algun calor.

2 I Estos meses de Octubre y Noviembre son alli los de la primavera, que empieza á reconocerse desde Septiembre, causando la distincion de tiempos aquella obscuridad de la atmósfera, que como si fuese un velo que se le pusiese al sol, no permite que con la eficacia de sus rayos penetre hasta la tierras y siendo igual la privacion en todas las horas del dia, quando no se rompe, sucede serlo el grado de calor, sin que haya causa que lo aumente mas en las del dia que en las de la noche: de esto nace que las mañanas, que regularmente son frias respecto del dia en todas partés, allí sea muy corta la diferencia que se nota. En las Capillas era algo mayor, por ser aquel valle cerrado, y por haber estado el termómetro mas expuesto al resplandor.

22 La primavera del Nuevo Orleans empieza, como en el Emisferio Septentrional, en Marzo: Abril y Mayo son los meses que corresponden á los que quedan citados de Bella-vista y las Capillas. Desde el 20 de Abril del año de 68 en adelante, era el calor, á las 6 de la mañana, en el Nuevo Orleans, de 17 grados arriba, y á las 3 de la tarde de 21 , estando el termómetro en la misma situacion que en 
Bella-vista; con que hallándose este parage en 30 grados, y minutos de latitud, y el otro en I2, era mayor el calor en el Nuevo Orleans de 5 grados; con la variacion de 4 desde la mañana al medio dia, y con la diferencia de que el sol distaba del Zenit del Nuevo Orleans en Abril i $8 \frac{1}{2}$ grados, y en Octubre del de Bella-vista grado y medio solamente. A la verdad, son necesarias las experiencias para convencer una disparidad tan notable como esta, la qual disuena, segun el órden regular de la naturaleza, y las reglas comunes de sus disposiciones: peyo así como el que estuviese cerca de una grande hoguera, resguardado de algun antemural que le defendiese de los efectos del fuego, percibiria ménos calor que otro que sin esta providencia estuviese algo mas distante, la naturaleza dispuso, que en sus tiempos el antemural de las nubes no dexase paso para que los rayos del sol penetrasen hasta la tierra, y que hiciesen ménos impresion en ella, moderando el calor en el primer tiempo que hace curso por el Zenit de aquel parage, concediéndole este privilegio, de que no participan los otros. Siendo la principal causa del mas ó ménos calor la direccion de los rayos del sol, tuvo la naturaleza providencia reservada para que allí no molestase con la actividad que parecia regular. Esto mismo sucede en lo que corre aquella faxa de territorio baxo, desde los 3 grados en la parte meridional, hasta el Trópico del mismo lado, ó con corta diferencia, y en quanto se extiende en anchura.

23 Es conveniente pasar despues de lo que queda dicho á explicar la variedad que hay entre la faxa ó mundo inferior en el Perú, y el alto, porque en estas distintas situaciones se reconocen efectos no ménos particulares que los que quedan dichos; y se verá que los frios excesivos del Nuevo Orleans, igua-
les 
les á los de otros parages que están en mas latitud, son los mismos que los de la medianía de la Zona Tórrida, entre la Equinocial y el Trópico de Capricornio; y que los calores mas activos de aquellos parages, en donde la respiracion se sofoca, yz dilatados los poros del cuerpo se disipan las fuerzas, se encuentran en tan corta distancia, que en lo que puede andarse en un dia sin violentar el paso, se ven á un tiempo los dos opuestos temperamentos; siendo necesario que los resortes del cuerpo, pasando aceleradamente por los grados intermedios, las dilaten y compriman, para acomodarse al grado que les conviene.

24 Son los temperamentos de aquellas dos distintas partes encontrados, no regulándolos la vulgaridad con atencion á la posicion del sol, sino á los accidentes; y así, en la parte alta llaman verano al tiempo en que no llueve, sin embarazarse en que sea entónces quando hiela y hace mas frio; y llaman invierno al llovioso, aunque el sol haga su carrera por aquel emisferio. En la parte alta empieza el verano en Mayo, siendo este mes en el que se prepara la entrada del invierno en la baxa. Dura hasta Noviembre, que van cesando los hielos en aquella; pero en esta cesan entónces las garuas, y se disipa el toldo que tiene escondido al sol, y formaba el invierno de ella. Empieza este en la parte altá en Diciembre, y entónces es quando desembarazado el sol comunica su calor á la tierra en la otra. De este modo quando es invierno arriba, es verano abaxo; y al contrario, sin que medie mas distancia entre ellas que lo que se tarda en subir aquella escala que conduce á los pináculos del mundo.

25 Será notable que allí, donde el calor es tan escaso que propiamente son grados de hielo los que se experimentan quasi todos los dias, las mieses to$\mathrm{H}_{2}$

men 
60 ENTRETENIMIENTO

men la perfeccion á que pueden llegar con estos mismos hielos, supliéndose con ellos lo que le falta de fuerza al sol, para conpletar la obra de la reproduccion; pero este asunto será de otro lugar, dexándolo suspenso por ahora, para continuar el del temperamento que va tratándose.

26 El verano se distingue alli del invierno en que es el tiempo en que toman las mieses el último grado de madurez, no obstante de ser entónces quando reynan los hielos, y el frio es mas constante: tambien en la circunstancia de ser los dias claros, el sol está despejado, y no es regular llover, nevar ni granizar: los vientos no son violentos, y los que reynan son de la parte de la costa, tocando algo del Sur con moderacion. En el invierno sucede todo por el contrario, los dias son nublados y obscuros, cesan los hielos; y el frio, aunque no es tan grande, es mas molesto, introduciéndose con las humedades de las nieblas congeladas en el cuerpo, porque entónces son frequientes: estas caen unas veces en copos grandes, y otras en partículas muy pequeñas, que penetran por los intersticios mas sutiles: entónces graniza, llueve, truena y vienta con variedad, sin que haya hora segura en que no sobrevenga alguno de estos incidentes. Los vientos son varios, y por lo ordinario de las partes de tierra : cesan enterarnente los que corren del lado del mar, las lluvias copiosas, y no pocas veces se ve llover y granizar á un mismo tiempo, mezcladas las gotas de agua con los granizos.

27 Es regla general allí que en el verano, quando se suspenden los hielos dos dias, se sigue inmediatamente llover, pero luego que falta la lluvia vuelven á continuar aquellos. Del mismo modo, quando quiere cesar el invierno se suspenden las lluvias, é inmediatamente biela, de suerte que alternándose 
estos con aquellos, es raro el dia en que no hiela mas ó ménos fuerte, ó que no llueva, nieve, ó granice; por este término es mas visible que en otras partes la agitacion continua de los tiempos en la reperida mutacion que tienen quando se interrumpen las lluvias, pasando el clima al opuesto extremo de hielo: cesan los vientos de las partes de tierra, y dominan los de la costa, penetrando hasta allá; y así los vientos siguen el órden de las estaciones.

28 Aquel temperamento varía muy poco en las distintas horas del dia: lo mismo sucede en el verano que en el invierno: de las 2 de la tarde á las 6 de la mañana, ó á las I I de la noche, es la diferencia $\frac{x}{4}$ de grado, ó $\frac{x}{3}$, y rara vez llega á medio grado: por una serie de observaciones de cerca de seis años, desde Noviembre de 1758 hasta Agosto de 1764 , está comprobada esta igualdad, sin que en unos años hubiese mas diferencia que en otros.

29 El invierno empieza en Diciembre, como queda dicho: el temperamento es en las piczas habitables de $8 \frac{x}{2}$ grados de calor hasta 9 : expuesto al ayre, pero sin recibir el sol ni su reflexo, es de 5 grados hasta 6 , debiendo entenderse por piezas habitables las que tienen precaucion de vidrios ó lienzos que las resguardan del ayre exterior. Este temperamento dura hasta Abril, y desde Mayo empieza el verano con los hielos, segun se ha dicho; entónces es lo mas comun señalar el termómetro expuesto al ay. re el término de la congelacion, y lo mas que baxa es tres grados de hielo; pero estando en el resguardo de las viviendas se conserva en 8 grados ú $8 \frac{1}{2}$, sin que en ellas haya fuego que las caliente. Estos grados de frio no son á la verdad considerables; pero siendo quasi continuos, y corta la diferencia que hay entre el verano y el invierno, pues consiste la mayor en 9 grados, resulta que los hie- 
los son permanentes en los parages que no baña el sol. Allí no es extraño mantenerse el termómetro constantemente 15 ó 20 dias en el término de la congelacion; y á la hora que sube de él es indicio de que se suspenden para llover en la forma que se ha explicado.

30 Comparando, pues, aquel temperamento con el de la Luisiana, se ve la diferencia notable que hay entre uno y otro. En una parte entre el invierno y el verano solo hay 9 grados de diferencia, que empiezan en 3 grados de hielo ó congelacion, y terminan en 6 de calor. En el otro es $41 \frac{1}{4}$ grados, desde $7 \frac{1}{2}$ mas baxo que el término de la congelacion hasta $33 \frac{3}{4}$. En la Luisiana es interrumpido el invierno por dias calurosos 10 que va de $7 \frac{1}{2}$ grados de hielo á 2 I $\frac{1}{2}$ de calor: en la parte alta del Perú el invierno lo está por dias de hielo y frialdad; y aunque el verano lo es tambien por otros de nieve y lluvia, rigurosamente es mudanza de voz, por la corta diferencia de 4 ó 5 grados, que es en lo que varían, y en la especie del frio, que el uno es húmedo, $y$ el otro seco.

3 I El verano de aquella parte alta será reparable sobrevenir en los mismos meses que en Europa, porque empieza en Mayo, y finaliza en Octubre ó Noviembre, contra lo que debia ser si se arreglase á la mayor inmediacion del sol al Zenit; pero allí no se sigue esta regla, y en su lugar se toma la de estar el sol descubierto, y que caliente la tierra, 1o qual sucede en los meses que se han señalado, y no en los otros. El decirse que calienta las tierras parece contra lo que se ha explicado ántes de la frialdad de aquel clima en todos tiempos; pero no es así, porque en efecto calienta el sol en verano, y quando mas calienta es quando son mas completos los hielos. Este verano y el calor de él no sobrevienen

quan- 
quando el sol corre los seis signos de la parte Austral, como queda dicho, sino quando corre los Septentrionales, hallándose mas apartado del Zenit.

32 Llaman de ordinario allí Sol de Puna al sol que se siente en los meses de verano; y quantos conocen aquellas tierras saben que es muy activo, porque quando da de lleno calienta tanto que no se puede tolerar, y causa dolores de cabeza fuertísimos, con otros malos accidentes. Es tal su fuerza, que parece hacer mas impresion que en los paises que son callentes por naturaleza, siendo allí expresion general decir que el sol abrasa, y la sombra hiela. Varias veces se ha hecho la experiencia, estando en un ámbito cerrado por todos quatro lados: á la una del dia, puesto á la distancia de dos pies fuera de la línea de la sombra, no se podia tolerar el calor; y pasando otres dos pies mas adentro de la sombra, no habia resistencia para el frio. La causa de esto es la sutileza del ayre, que no retiene en sí los corpúsculos ígneos que reflectan en la parte iluminada, y así no hay allí resplandor : la parte donde el sol no hiere es verdadera sombra en quanto al temperamento, y la otra es parecida á un volcan : por esta razon el calor que la tierra contrae en el discurso del dia es casual, perdiéndolo desde luego que se oculta; y desde esta misma hora empieza á helar, porque la atmósfera no conserva las qualidades del calor como en las partes donde el ayre tiene otra densidad.

33. En el invierno acontece muy diverso de esto; los dias son nublados, el sol quando se descubre es por pocas horas, los vientos son recios y varios, Ias lluvias quasi diarias, segun que queda dicho, y las tempestades de truenos les acompañan por lo comun. En la entrada del que allí tiene lugar de otoño, el frio, aunque no es de hielo, es mas moles- 
to, porque penetra, y no hay sol que caliente; pero entre todas estas cosas, la que distingue con mas propiedad las dos estaciones, es la vegetacion, que al igual de Europa hace sus progresos desde Noviembre hasta Abril, renovándose entónces las simientes y plantas. Sigue despues el estío desde $\mathrm{Ma-}$ yo hasta Octubre, en cuyo intermedio todo está seco y árido: de aquí procede la particularidad de que las estaciones sean encontradas al órden regular del curso del sol, determinándolo por los efectos y accidentes, y por el órden de la reproduccion.

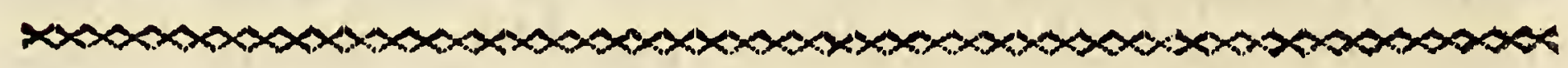

ENTRETENIMIENTO V.

Sobre los distintos temperamentos de la parte alta de la América, efectos que producen, y causas de lo que alli se experimenta contra el órden general de las otras partes.

No lla parte elevada de la tierra: hay en ellos de todas clases, segun la altura y disposicion de los territorios. A proporcion de aquella son los hielos mas constantes en el verano, y las nieves y granizos mas comunes en el invierno; y quanto mas se desciende van siendo mas calurosos, y ménos regulares los frios. Aquellas grandes profundidades por donde corren los rios, que por allá llaman quebradas, y dice el nombre lo que en realidad se representa, son lugares que tienen todos los accidentes de la Zona Tórridd. El ayre tiene mas densidad que en los otros, $y$ el calor del sol lo imprime en él con mas efica- 
QUINTO.

cia que en donde está mas ligero: el abrigo de las eminencias, que forman aquellas concavidades, contribuye á que la reverberacion sea fuerte; y de una y otra causa resulta, que los calores son sensibles, y que la tierra lo dé á entender en sus producciones.

2 La profundidad, ó quebrada de Iscuchaca, de la que se ha dado ya alguna noticia, no es de las mas profundas, y consiguientemente su temperamento no es tan cálido como en otras. En los meses de verano el termómetro, colocado dentro de las viviendas, está en I I grados, y su mayor variacion en 10 mas entrado del dia es $I_{\frac{1}{2}}$, subiendo hasta I $_{2} \frac{x}{2}$. En el invierno se halla desde I4 hasta 16 , sucediendo esto constantemente en todos los años. Esta diferencia que tiene del temple de Guancavelica, aunque no es grande, causa efectos muy sensibles en animales y vegetales, de tal modo, que al llegar á la mitad de la cuesta por donde se baxa, se sienten los movimientos de la dilatacion sensiblemente; porque no correspondiendo todas las partes de la organizacion con igual prontitud, hay alguna sofocacion mas ó ménos grande, que se manifiesta en zumbido pronto de los oidos, y torpeza de este sentido, en el hormiguéo de las extremidades del cuerpo, y en otras señales semejantes, no dexando duda proceder de lo que se dilatá la sangre, sin dar tiempo á que los vasos tomen la correspondiente extension. La ropa que se lleva del otro temperamento, pesa é incomoda; y á este respecto parece haberse salido de un invierno, y estar en un verano repentino. Esta mutacion sucede en el espacio de 8 leguas, que son las que hay de un parage al otro, y se andan en otras tantas horas, ó en ménos tiempo: con que no es menester mas tiempo que este para transferirse de los hielos al calor, ó de un invierno de frios rigurosos á un verano, cuyos calores, aunque 
que en realidad son moderados, no dexan de ser sensibles para los que se hallan habituados al clima frígido del otro parage.

3 Las producciones de la tierra son el termómetro y regla de aquellos temperamentos. En los frigidos, como Guancavelica, solo se crian pampas, que es lo que en Europa llaman batatas de Irlanda. La cebada crece, pero no da grano, y allí no prevalecen los árboles frutales de ninguna especie. En Iscuchaca grana la cebada, se produce el trigo, y tambien el maiz, que requiere temperamento de mas calor que aquel grano: allí subsisten los sauces, y los cedros: hay otras especies de árboles, y las faldas de aquellas pendientes están pobladas de arbustos, que no se encuentran en los territorios altos.

4 A esta semejanza, en otras profundidades mas baxas que aquella, el calor se aumenta tanto, que se cria la caña del azúcar, cuya planta requiere mucho calor para madurar; y los árboles de climas cálidos dan todo género de frutas, propias de ellos, como los plátanos, las piñas, aguacates ó paltas, guabas, por otro nombre pacaes, y todo género de raices y legumbres. En estos lugares profundos no falta la division de tiempos, pero la diferencia de unos á otros no es grande: sin embargo de ello, las mañanas, ántes de salir el sol, son frias mas de lo que ccrresponde á un temperamento de primavera regular; y en el verano no dexa de sentirse el hielo alguna vez, que aunque no es grande, es suficiente para no dexar de hacer daño á las plantas.

5 Dentro de un territorio de cortas leguas se ven allí los quatro tiempos del año constantemente : en uno los frios rigurosos del invierno; en otro las delicias de la primavera, sin las molestias del otoño; y en otro los calores fastidiosos del verano, y las producciones de la Zona Tórrida. Esto sucede, siendo 
QUINTO.

do notable el tenerlas trastornadas, mediante que quando el sol se halla mas distante del Zenir, se experimenta el verano, como queda prevenido; y quando está mas próxîmo, y que deberia calentar mas, es el invierno. De esto sacamos que la naturaleza no se sujeta á reglas precisas, y que tiene reservadas providencias para invertirlas, sin interrumpir el órden necesario para la subsistencia.

6 En la corta distancia de ro leguas, que es todo lo que puede mediar entre el territorio baxo $y$ el alto, se ve el extraordinario deberse de estal encontrados los tiempos. Parece fenómenomirar esta circunstancia como una de las mas raras particularidades que hay en aquellos paises. La diferencia de altura, $y$ las profundidades encaxonadas y abrigadas pueden ocasionar, como se ha explicado, el mas ó ménos frio, y el grado de calor mas activo; pero la contrariedad de tiempos es cosa mas singular. El invierno es en el terreno baxo en los meses de Junio hasta Noviembre, que es en el que corresponde, por la carrera que lleva el sol en aquel tiempo en los signos Septentrionales; pero que en este propio tiempo sea verano, cuya estacion es diametralmente opuesta en la parte alta, sin que medie entre las dos mas distancia que la que hay desde el uno al otro por aquel tránsito inclinado de las montañas por donde sube, parece repugnante á la comprehension, no ménos que el que la naturaleza los distinguió tan por entero, que no hubiese cosa en ellos que tuviese semejanza. Las nubes continuas y las garuas causan el invierno en la parte baxa: las nubes con las lluvias, nieves y granizos lo causan igualmente en la alta, sucediendo lo contrario en el verano; y así es consiguiente, que quando abaxo el tiempo es claro, lo sea arriba obscuro; y á este modo anden opuestas las estaciones. 
7 La floxedad de los vientos Sures, y tal vez la suspension de ellos, por intervalos de algunos dias, causa la nube que encubre el sol en la costa y parte baxa; perque no habiendo viento que la mueva, están los vapores húmedos, que se levantan de la tierra, parados. Esta nube no se pone tan alta, como lo está la parte superior de la tierra, deteniéndose á una determinada elevacion. Los vientos Sures, que son los continuos en aquellos mares, Hamándose así aunque toquen algo del Sudoeste, pierden la fuerza en la parte baxa de la atmósfera, manteniéndola en la que está mas alta; y corriendo por un espacio superior á las nubes, igualan con el nivel de la tierra alta, y corren por ella sin embarazo. De este modo no solo no dan lugar á que se formen allí nubes, sino que siendo constantes las disipan, haciéndolas correr hácia la parte opuesta. Por el contrario, en el verano de la tierra baxa, los vientos corren con fuerza inmediatos á su superficie, disipan las nubes, y los dias son claros. Estos vientos no se levantan entónces á toda la elevacion que necesitarian para bañar la alta; y dominando entónces con variedad los de tierra; dan lugar á que se formen las nubes, que se hagan densas, y que ocasionen lluvias; pero como en la rarefaccion que el ayre tiene allí, agregada á la abundarcia de partículas nitrosas, que por su sutileza se levantan hasta aquella altura, ocasionan el frio, que es comun en todo tiempo, nace de ello, que lo que habia de ser agua se congela unas veces en granizo, otras en nieve, y no pocas mezclado esto con el agua. Los vientos Sures en aquellas partes son lo mismo que los Nortes en el Emisferio Septentrional: limpian la atmósfera; son frios, porque corren de las partes meridionales, $y$ el sol se halla en aquella estacion en la mayor distancia del Zenit: todas estas causas con-

cll $\mathrm{C}^{-}$ 
curren para que se experimenten hielos; siéndolo tambien para que estando en la sombra se sienta frio, y pasando al sol calor: con los hielos se endurece la tierra, comprimiéndose sus poros: la reflexion del sol debe ser mayor entónces que quando sus rayos hieren una superficie espcnjosa; y á esto se debe atribuir, que el sol de Puna sea mas activo é insoportable que el de los territorios templados, ó cálidos, en donde todos los cuerpos están dilatados, y sus porosidades son mayores que en el otro caso. Del mismo modo, los poros del cuerpo se hallan cerrados con el frio; la actividad del sol no encuentra disposicion para la transpiracion; y el efecto del calor es mas sensible en las partes externas, que las quema ó achicharra, que los de temperamentos que son verdaderamente cálidos. Otra particularidad tiene el sol de Puna, y es, quie aunque parece que abrasa, y estando parados es inaguantable, no causa sudor, ni es suficiente para ello el que se agite el cuerpo; reguldrmente la causa es por la frialdad que conserva el ayre, la qual comprime los poros, no dándoles lugar á que transpiren con facilidad: de surerte que de una parte se siente el calor por la reflexion de los rayos del sol; por otra el frio, que es natural en la ligereza de aquella atmósfera: y en esta contrariedad de climas á un mismo tiempo padece la naturaleza, y sobrevienen las incomodidades que quedan dichas; pues si pudiese desahogarse descansaria, asi como sucede en los temperamentos cálidos. 8 Sin otra causa mas que los vientos Sures, y
la forma en que reynan, parece estar explicada la de las estaciones encontradas en aquellos parages, y la de los inviernos frios en la medianía de la Zona Tórrida, entre la Equinocial y el Trópico de Capricornio, contra lo que debia suceder si solo se 
atendiese á la proximidad del sol; pero su influencia se modera con las otras causas: y en donde el calor debia ser continuo, es moderado respecto del que hay en otros parages. La diferencia de alturas, y el abrigo de las aberturas ó quebradas, son causa, aun alli mismo, para la variedad en los climas; bien que las estaciones no son encontradas, como sucede respecto del pais baxo.

9. El temperamento de la Luisiana en el verano es mucho mas cálido, sin comparacion, que el del teritorio baxo del Perú, y que el de las profundidades del alto; y no obstante este mas calor, la caña de azúcar prevalece en él con dificultad, quando en estos otros se cria regúlarmente: la causa de ello es, que en los meses de verano, en la Luisiana no tiene todo el tiempo que necesita para completar el período de la vegetación, interrumpiéndola los frios y hielos alternados del invierno. En el otro pais no sufre estas alteraciones, porque la desigualdad del temperamento entre el invierno y verano no es grande; y necesitando allí el término de tres años para ponerse en estado de madurez, no le perjudica el temperamento de los del invierno que intervienen: lo que en la Luisiana no puede ser; mediante que entre dos veranos median hielos que la secan, y detienen el curso de la vegetacion, siendo preciso que crezca y tome madurez en el tiempo que dura el verano.

Io Por medios opuestos sigue la naturaleza cierto régimen de semejanza, y parece conformarse unos climas con otros, aunque estén muy apartados. En la Luisiana alternan en el invierno dias de tanto calor, que pudieran tomarse por verano de otras partes; pero en el verano no alternan dias de hielo, y los tiempos, segun queda dicho, están en continua variacion de frio y calor. En el verano de la parte al- 
alta del Perú sucede lo propio. Los días de hielo, que son los de verano, están interrumpidos con otros de invierno, al modo de aquel pais, porque suspendiéndose la fuerza de aquellos, siguen inmediatamente las lluvias, nieves y granizos, que son señales de invierno, y el temperamento se halla igualmente en la misma agitada alternacion que la que tiene allá. Lo que esto tiene de particular no es la cesacion de un temperamento, para que le suceda otro mas moderado en su especie, sino el exceso de pasar repentinamente del uno al otro en extremos opuestos.

I I El verano de la parte alta del Perú da la ultima sazon á los frutos; pero si se adelanta los picrde enteramente. Puestos en sazon durante el invierno, con las lluvias y la moderacion del frio, luego que empiezan los hielos, desde el primero se agostan, y al tercero están enteramente secos, haciendo el hielo y el sol de Puna lo que habia de resultar solo del calor del sol: de esto nace que quando sobrevienen los hielos, ántes que hayan tomado toda la madurez que conviene, se secan fuera de tiempo, y quedan sin sustancia. Ios efectos del hielo son mas prontos que los del sol, porque en el término de uno, ó dos dias hacen con las mieses lo que el sol por grados en el discurso de muchos.

I 2 En las profundicades no son los hielos los que perfeccionan las cosechas; forque aunque alcanzan algunos, segun queda explicado, no son fuertes ni continuos; pero quando empieza la estacion de ellos en lo mas alto, siendo los dias claros está el sol descubierto, y calienta lo bastante para que se perfeccionen; y por esto su total madurez la tienen del calor del sol. De este modo se ve allí el raro fenómeno de que en una parte se hace por efecto del frio lo que en otra procede del calor, siendo en todas á un mismo tiempo.

Los: 
13 Los efectos del hielo y de la sutileza del ayre son tan sensibies, que se perciben igualmente en los cuerpos y en los metales. Los ayres son secos y sutiles; estos causan tal aridez, que las partes delicadas del cutis se rajan, y particularmente los labios poniéndose doloridos, y brotan sangre; las manos se ponen ásperas y escamosas, y en las articulaciones de los dedos por la parte superior de ellos son las escamas mas gruesas que en el resto, tomando un color renegrido, que permanece, sin que el lavarse de continuo lo quite: á esto llaman cbuño, que es palabra de la lengua de los Indios, y significa cosa arrugada $y$ curtida con el frio. Obsérvase en los metales la penetracion del hielo en aquella atmósfera, y lo manifiestan las campanas, que generalmente se rajan, sin que las liberte de este mal la precaucion de darles mas grosor que el que se acostumbra de ordinario. Esta, que no se ve tan comun como allí en otras partes donde hay hielos mas fuertes, prueba que concurre á ello ademas la sutileza del ayre, ó su ménos densidad.

I4 La frialdad del clima en el verano precave alli de corrupcion, siendo de tal modo, que los pescados que se cogen en el mar, de 50 ó 60 leguas, se llevan $y$ se comen tan frescos y buenos como si se estuviese en la misma orilla de él. No solo se usa de ellos quando llegan, despues de haber hecho viage largo, sino que se guardan el tiempo que se quiere, $y$ se encuentran siempre en aquel mismo estado que tuviéron al principio. Para esto tienen la precaucion de hacer las pescas de parte de tarde; y luego que llegan con él á las playas, lo abren para sacarle las tripas, y puesto en las banastas caminan por el pais baxo la primera noche, de modo que al amanecer hayan llegado á las primeras alturas de la Puna: estando allí no tienen peligro de que se dañe, por- 
porque recibiendo la primer helada del nuevo temperamento, queda asegurado para conservarse todo el tiempo que se quiere. El pescado en esta forma está endurecido; quando se quiere usar de él se pone en agua por espacio de media hora, lo qual se hace para que se deshiele, y vuelva á su estado natural, en cuyo modo vuelve á quedar como si se acabase de sacar del mar. La diligencia de deshelarlo es tan precisa, que sin ella no se le puede separar la escama, ni cuece, quedando siempre duro y empedernido; pero puesto en agua fria, que es la del tiempo, se liquidan las partes que están coaguladas, y queda flexíble y docil : en agua tibia ó caliente no se deshiela como en la del tiempo. Lo mismo que con el pescado sucede con las carnes y las frutas : las primeras duran quanto se tarda en consumirlas, sin que disminuyan su bondad; las segundas se conducen de las profundidades, ó de otros territorios baxos, que llaman calientes, y con el beneficio del hielo se mantienen sin sobrevenirles corrupcion. Lógrase la ventaja de que no habiendo en las partes altas fruta alguna, se consiguen las mejores, porque todas ellas están heladas naturalmente. En el invierno no disfrutan de esta comodidad aquellos paises, embarazándolo la abundancia de las lluvias, que son freqüentes, como queda dicho.

I5 Aunque en el invierno es aquel pais tan lluvioso, que son raros los dias en que no suceda, es el ayre seco en todos tiempos: suelen las paredes de las casas estar manando agua, que se introduce for las porosidades de los materiales, y los suelos estar húmedos durante el tiempo de las lluvias, sin que for esto se reconozcan los efectos de ella, ni en la salud ni en los metales, que uno y otro se conservan sin alteracion. Al contrario sucede en el territorio baxo; las lluvias son cortísimas, pues consisten en aqticllas K

me- 
sensacion extraordinaria, que ocasiona la displicencia del cuerpo; y por esta causa ni basta el abrigo, ni el calor, ni la agitacion para evitarlo. Esta incomodidad dura 20 ó 30 dias, hasta que poco á poco se disminuye, y la naturaleza se habitúa al clima. La misma novedad en los principios vuelve en lo sucesivo por el lado opuesto. Acostumbrada la naturaleza á aquel temperamento, no se le hace despues tan sensible el frio, como sucede en las partes donde entre el verano y el invierno hay muchos grados de diferencia. Las casas tienen poquísimas precauciones. En el vestuario, aunque regularmente se trae el de invier. no, no es con la duplicacion que parece pedirlo la destemplanza del ayre. No se usa de fuego para calentarse, y á este respecto se vive como si se estuviera en una primavera, sin faltar aquellas señales que convencen lo contrario en el chuño de las manos, en las aberturas de los labios y la aridez del cutis, verificándose en ello la disposicion que tiene la naturaleza para acomodarse sin molestia á los distintos temples quando son continuos.

I6 Por lo que queda explicado debe entenderse variar aquellos temperamentos á proporcion de la mayor elevacion en que se hallan, ó de la profundidad en que están, y que en esta parte se diferencia la tierra alta de las restantes, pues las reglas, que son comunes, se ven totalmente variadas en tanto grado, que las estaciones, los tiempos y los efectos son diversos : allí es invierno quando correspondia ser verano: reynan los vientos contrarios á los del pais baxo: llueve mucho, y es el ayre seco: hicla, y entónces es quando se maduran las mieses, ó á lo ménos toman el último grado de perfeccion, aunque son pocas las especies que pueden prevalecer: y últimamente, el frio y el calcr se sienten de distinto modo que en las demas partes, el uno abrasando, y el ctro K 2 . obran- 


\section{Q UINTO.}

rio no lo padecen las que alli no lo han experimentado, bien que nunca dexan de tener novedad. En las altas montañas de la Europa, y en las de las otras partes de la sierra, no dexa de sentirse algo que se parece á esto, particularmente por las personas délicadas; pero no son los efectos tan sensibles y graves, ni tan generales como allá, procediendo en estas partes de la rarefaccion del ayre y el frio que se experimenta en las alturas, cuyas dos circunstancias es preciso que causen algunas alteraciones.

I 8 Otro accidente se observa con los animales en aquel clima, y es, que quando suben de las planicies á los cerros ó Punas, como del parage en donde se halla alguna poblacion, á los que le circundan, es tanto lo que se les comprime la respiracion, que sin embargo de hacer varias pausas para que tomen aliento, suelen de repente caerse, y quedar muerros. Las gentes de allí llaman á esto pasarles la veta, pretendiendo que generalmente por todas aquellas serranías no faltan vetas de minerales de algun metal, y que de ellos se exhalan por las porosidades de la tierra partículas de antimonio, azufre, arsénico y otros, atribuyéndoles estos accidentes. Semejante opinion tiene en su contra, que si fuese así, los que van montados en las bestias, pues experimentarian el mismo daño, y tambien aquellas quando están paradas; pero no sucede esto, porque ni los unos ni los otros reciben mal; y es de creer que la causa sea la sutileza del ayre, ayudada de algun otro cuerpo que se halle esparcido en él, sin salir inmediatamente de los poros de la tierra. Hay para ello tambien la circunstancia de no tener probabilidad que se encierren minerales en lo interior de todas las alturas ó montañas en donde sucede esto, por no reconocerse señal exterior que lo indique. y que para que fuese así sería preciso que todo aquel terreno alto en muchos cente-

na- 
como se hiciera en orra parte, en donde la atmósfera tuviese la densidad regular.

20 Por la misma razon de ser el ayre ligero es propicio para los asmáticos, que contraen la enfermedad en otra mas densa. Conocen allá esta por el nombre de alogos, y es bastante comun: por esto los que la padecen en el pais baxo procuran irse al alto, en donde, aunque no sanen del todo, viven sin molestia. Por el contrario, los que la padecen en el pais alto se hallan bien pasando al baxo; y así la mudana za de atmósfera de mas á ménos densa, y de ménos á mas, es medicamento seguro para este género de achaque, cuya noticia podia ser útil en la Medicina, enviando los enfermos de unos parages á otros, aunque la diferencia de altura no fuese tan considerable como aquella.

2 I Alguna cosa de esta dificultad en la respiracion se reconoce en los territorios altos de la Provincia de Quito, pero no es tanto como en la otra parte, debićndose atribuir á la circunstancia de estar la una en la Equinocial; ó muy cerca, y la otra no: de esto nace la opinion comun de que las Punas del Perú son mas rígidas y fuertes que las otras; debiéndose entender, que lo que se dice de las de Guancavelica es general en todas las otras que corren hácia el Sur.

22 Para la mejor inteligencia, ántes de concluir este Entretenimiento, es conveniente advertir, que lo que llaman Prana en el Perú, es lo mismo que Páramo en el Reyno de Quito, y que todo aquel pais frígido descampado, en donde no se habita, o no liay poblaciones, tienen el propio nombre, bien que hay unas Punas mas altas que otras; scgun se hallan mas elevadas. De aquí proviene dar á los soles fuertes la. denominacion de Soles de Puna, la misma que á los vientos frios desapacíbles é incómodos. 


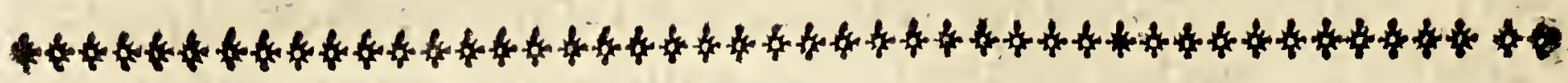

\section{ENTRETENIMIENTO VI.}

\section{De las producciones vegetables de los varios territorios.}

No es particular que en climas diferentes, $y$ donde los temperamentos son tan diversos, las producciones de la tierra sean distintas entre sí. El calor y la humedad son los medios sensibles de la vegetacion; y á proporcion que es mayor el grado de cada una de estas dos causas, hallándose unidas, la vegetacion es mas pronta y vigorosa en aquellas especies que lo requieren; y del mismo modo, otras que necesitan de ménos calor, $y$ aun de algunos grados de frialdad, prevalecen en donde la encuentran, sin que se vean en los terrenos cálidos, ni en los parages que abundan de humedad: de aquí nace', que tan favorable es para las unas el calor en grado excesivo, como para las otras la frialdad mas ó ménos grande; entendiéndose lo mismo de la humedad ó sequedad. Con todo esto es mas comun que los campos se vistan de toda suerte de plantas en los climas cálidos y húmedos, que en los frios; y son muchas las especies que prevalecen en aquellos, respecto de las pocas que visten la tierra en estos, sucediendo que los unos son naturalmente frondosos, y los otros se miran como áridos: en aquellos ve renovarse la naturaleza por instantes; y en estos, aun quando quiere dar señales de su mayor vigor, se registra desnuda la tierra, y que míseramente da algunas señales de no ser del todo estéril. Esta proporcion con los temperamentos es necesaria para la variedad, que es la hermosura de la naturaleza, pues por su medio se

ven 
ven multiplicadas las especies en tanto grado, que se requiere mucho estudio y aplicacion para conocerse las mas comunes.

2 La naturaleza, liberal en todas sus providencias, distribuyó los dotes de su generosidad cor proporcion á los climas, á los territorios, y á las propiedades del ayre: hizo comunes entre todos, ó en los mas, ciertas cosas, y reservó otras para distinguir con ellas aquellos que le viniese mejor.

3 Entre la parte baxa del Perú, y la alta; entre estas y las que están cerca de la Equinocial; y entre unas y otras, y las que están debaxo del Trópico, se reconoce tanta diferencia, que parece variada la naturaleza, porque lo que se ve en la una no se encuentra en las otras; pero lo notable es, que en la Luisiana se hallan algunas cosas de las que son comunes en la cercania de la Equinocial, y otras diferentes de ellas é iguales á las de Europa, no faltando tambien algunas que son extrañas de uno y otro pais. La parte baxa del Perú, que llaman Valles, y son llanadas dilatadisimas en lo largo de Norte á Sur, producen de sí mismas muy poco, por ser territorio de arena; pero ayudadas del arte, y fecundadas con humedad, brota con vigor aquellas plantas que son adequadas al clima; pero esto es solo en los sitios por donde corre algun arroyo ó rio, donde se ven árboles y cultura, como que teniendo el grado de calor que se requiere, solo le falta el de la humedad, la qual se le ministra por acequias grandes que se hacen, y de unos campos estériles se disponen otros, cuya fertilidad no tiene que envidiar á los mas pingües. Allí prevalecen el maiz, las batatas, que llaman camotes, $\mathrm{y}$ en otras partes moniatos, yucas, y muchas especies de simientes, granos y raices, como la cara de azúcar, á cuyo simil crecen tambien árboles L.

fru- 
frutales de aquellas especies, que son regulares allá. En esta clase entran los chirimoyos, aguacates, ó paltas, guabas, ó pacaes, nísperos, guayabos, lucumos, palmas, y plátanos, con otros que no dan frutas de exquisito gusto, como los algarrobos, guarangos, sapotes silvestres, y otros varios. Tambien prevalecen los fiutales de Europa, como naranjos, limones, limas, manzanas, nogales é higueras; y de los de fruta de hueso, duraznos, priscos, melocotones, ciruelas y olivos; pero entre unos y otros no se ven encinas, alcorncques, ni castaños, y si de estos hay algunos es hucia las partes del reyno de Chile, cuyo clima es totalmente igual al de España, con las quatro estaciones del año bien distinguidas.

4 Es necesario tambien hacer distincion de la parte baxa con atencion, no á la mayor inmediacion de la Equinccial, sino á los vientos que reynan. En aquel dilatado espacio, en donde los vientos Sures son perpetuos, que es desde los 26 ó 27 grados al Sur de la Línea, hasta los $3 \frac{x}{2}$ grados del propio lado, donde está el pueblo de Tumbes, prevalecen con mas ó ménos abundancia las plantas que quedan dichas, y ademas de ellas hay tambien las parras y cepas de uvas; pero desde los $3 \frac{x}{2}$ grados Sur hasta pasar la Línea, y todo el ámbito que hay desde ella hasta el Trópico de Cáncer, abunda solo en árboles silvestres y frutales, no prevaleciendo en plantas menores otras mas que las que son propias de paises de mucho calor y humedad; y así los cedros de distintas castas, los caobos, los ceibos, las marias, los éroanos, granadillos, las palmas de muchas especies, y otros diversos se encuentran tan tupidos, y. son tan corpulentos, que no pueden penetrar por entre ellos los rayos del sol, texiéndolos una infinidad de vejucos mas ó ménos gruesos, y las plantas pequeñas, con tanto enlace, que es dificil des- 
desembarazarse de su confusion. La parte del pais baxo, donde los vientos Sures son continuos, carece de lluvias; y aunque tiene el grado de calor que conviene á aquellos otros árboles, les falta la correspondencia de humedad, que es esencial para el brote de la vegetacion. En los parages donde esta se halla pór la industria del riego, que los coquiones distribuyen, sacándose de los rios, no dexan de prevalecer; pero son árboles plantados expresamente, y no producidos por sí, y sin cuidado, como sucede en los otros.

5 Desde la parte baxa hasta la alta, cuyos temperamentos y el ayre son enteramente opuestos, se siente por grados la diversidad de producciones. En las quebradas profundas, y en los parages ménos altos, se produce con vigor la caña de azúcar, no tanto con el beneficio del riego, quanto por la abundancia de las lluvias, y á este respecto los árboles y frutas que crian son las de los climas de la parte baxa; pero como el grado de densidad de la atmósfera no es el mismo que allá, quanto esta es mas ligera, son las vegetaciones ménos prontas, pero los frutos no son de inferior sazon. En los parages que no son quebradas profundas, ni tampoco de los mas altos, prevalecen especies que son regulares en Europa, y que requieren temple frio, como el trigo, la cebada, y otras simientes; pero en árboles es muy. escasa, no hallándose allí los pinos, robles, castaños, encinos, alcornoques, cuyas especies son desconocidas, y solo de los pinos se dice, que se encuentran en la parte meridional hácia el reyno de Chile, no habiéndolos en lo demas de la cordillera, desde la Equinocial hasta los 23 ó 24 grados. Los sauces son muy comunes en aquellos temperamentos medios, y los cedros no dexan de prevalecer en ellos, aunque con lentitud. 
6 Los parages elevados, que verdaderamente son frios, crian tres especies de árboles particulares á ellos; estos son los quinuales, especias y casis: todos indican en su estructura y en el colorido de las hojas la desapacibilidad del temperamento. Son los quinuales, ó por otro nombre quisuales, de regular altura y corpulencia, poblados de ramazon competentemente, y. como á la altura de dos varas se divide el tronco en distintos brazos. La hoja es menuda y gruesa al modo de las encinas, ó mas propiamente al de las carrascas: su color es opáco, de un verde obscuro macilento: su corteza es particular en circunstancia del quantioso número de capas de que se compone, con el que parece haber intentado la naturaleza hacer al tronco otros tantos abrigos para defenderlo de la rigidez de los climas en donde prevalece: esta corteza, pues, consiste en el grueso de una pulgada poco mas, compuesta de crecido número de capas, que estando pegadas entre sí, se separan sin dificultad, y no es facil averiguarlas, pues habiendo contado mas de I5o, faltó la paciencia á vista de no haber llegado á la mitad. Dichas capas son muy delgadas, aun mas que el pafel, lisas, suaves al tacto, y de un color que tira á roxo claro. Al arrancar del tronco un pedazo de corteza empiezan á dividirse de si mismas; y debaxo de aquel pedazo, que parece ser el tronco, se saca otro de innumerables capas, y mas delgadas, tersas, y xugosas que las exteriores. Al fin de todas está el tronco, que es de una madera obscura, dura, compacta y pesada. El fruto es una especie de grano menudo en forma de racimos, del que no se conoce uso alguno.

7 Se podria equivocar el árbol que llaman espesia con el quinual, mirado de repente, si su corteza no fuese enteramente diversa. La de este es del grueso de dos á tres líneas, bastante dura, y aunque 
S E X T O.

que tiene algunas pequeñas grietas, en el total es unida, dura, y se halla tan adherente al tronco, que no se dexa separar con facilidad. La hoja es algo mas grande que la del otro, pero del mismo color; y la frutilla que da es igualmente mayor. La flor de estos árboles es al modo de los olivos, pero de color obscuro, de modo que es preciso mirarlos con cuidado para distinguirla de la hoja.

8 En alturas mas elevadas, cuyo clima es asimismo mas frio, se crian los casis, cuyo árbol es menor que los antecedentes, y á proporcion el tronco ménos grueso: al símil de aquellos da muestras del rígido y continuado invierno, al que resiste con su dureza: la madera es obscura, y la corteza delgada, y muy unida con el tronco: es de mucha dureza y peso, y no teniendo nada de vidrioso, la prefieren para las obras que se hacen en lo interior de las minas. Fuera de estas tres especies de árboles no se crian de otros por allí, lo qual conviene con lo que se ha dicho, de ser escasa de producciones naturales.

9 Aun cn las yerbas hay tambien nctable diferencia. Desde que se sube á temperamento algo frio se empiezan á ver pajonales, que en nombre propio son icbales, porque á la paja que crece allí se llama icho: el de temperamento ménos frio es mas largo que el de mayor frialdad, y tambien mas espeso, $\mathrm{y}$ la hoja mas fuerte, pareciéndose al esparto, del qual se diferencia en ser mas endeble.

Io En la parte baxa la yerba comun es la grama, y no se encuentra entre ella icho alguno; de modo que cada clase de terreno tiene por yerba comun una distinta del otro. Ademas de estas, que son las de abundancia, no faltan de otras varias especies, lo qual sucede en las cercanías de los arroyos ó rios, en las partes donde el frio reyna ménos, y en las quebradas. El trevol es entre todas de 


\section{6}

de las mas comunes en aquellos párages donde no prevalece el icho.

I En los lugares donde el frio no es de lo mas excesivo, hay una planta que brota un vástago como de una vara ó vara y media de alto, y al fin de él hace como un penacho: el grueso de este vástago es como pulgada y media de diámetro: introdúcense en él ciertos gusanos, como de dos pulgadas de largo, y grueso algo ménos que el dedo pequeño. Quando el vástago se pone seco, los gusanos están en su mayor vigor, y son de un color ceniciento. Estos, comidos, tienen la propiedad de hacer venir leche á las mugeres, aunque no estén en positura de tenerla. El modo de usarlos es cocidos ó fritos; no tienen gusto fastidioso ni malo, consistiendo su carne en una crasitud al modo de tocino. Es experiencia hecha varias veces, no de casualidad, sino con intento determinado, y nunca han faltado los efectos. Esto se hará repugnante por no ser comun, pero allá es tan corriente, que en pidiendo gusanos para la leche, luego los traen en sus vástagos, que son al modo de cañas, y usan de ellos las mugeres que los necesitan para facilitársela, ó hacer que abunde. Igual virtud tiene la yerba llamada nuñu-quebua. El nombre nuñu significa los pechos, y de él se deriva el del ama que da de mamar.

I 2 Otra planta hay de una rara virtud para curar y cicatrizar toda suerte de llagas; llámanla yerba de mataduras, en la lengua de los Indios buallbua, por ser con la que curan las de las bestias: es tan eficaz, que en cortos dias las pone buenas; y el modo de aplicarla es molida, poniendo sus polvos sobre la parte que se halla mala, sea llaga, herida grande ó pequeña; y lo que hacen los ingredientes, de que usa la cirugía en mucho tiempo, facilita esta sin auxilio de preparacion, ni de otros simples, $y$ con 


\section{$S E X T O$.}

con la ventaja de la brevedad.

I 3 Si no son muchas las especies en plantas grandes y pequeñas de aquel pais, tienen la excelencia de hallarse en ellas alguna virtud buena; al contrario de lo que sucede en los territorios de climas calientes. La cascarilla, ó quina es de temperamento frio, perteneciente al territorio alto, y no es en el de Loxa, en donde únicamente se cria, participando de esta ventaja otros muchos: sus virtudes son bien conocidas y apreciadas, á correspondencia del beneficio que por su medio consigue la salud. En los temperamentos calientes de la Zona Tórrida hay incomparablemente mas fecundidad en especies, y mas hermosura en los árboles; pero entre los muchos buenos, y de maderas exquisitas, no faltan algunos que sean nocivos, como sucede con el manzanillo, que es bien comun, cuya sombra hincha á los que se acogen á ella contra los fuertes calores que allí reynan. El guao, ó guau es una planta en forma de arbusto, cuya malignidad parece no le dexa levantarse al igual de los otros. Su veneno es tan pronto, que solo con el contacto hace hinchar la parte del cuerpo en donde toca, y la indispone de tal suerte, que necesita de alguna curacion para restituirse á su ser. Esta mala calidad de las plantas no quita que en la muchedumbre haya algunas con virtudes particulares, pues vemos que aun las que son venenosas se aplican con conocimiento y buen éxîto á ciertas enfermedades. Entre las de la isla de Cuba hay con particularidad una, que merecia ser mas conocida de lo que está. Esta es el árbol que llaman ocuge, el qual destila una resina tan adecuada para las relaxaciones, que las suelda enteramente. Aseguran las gentes de alli, con el fundamento de la experiencia, que es de tanta actividad, que puesto el parche de ella en donde encuentre articulacion, la une y consolída, quitándo- 
le totalmente el movimiento; y por esto es necesario al tiempo de ponerla cuidar de que no se extienda á parte donde pueda resultar daño. Dicen tambien que su virtud es igual para relaxaciones antiguas como para las recientes, y lo propio en las personas de mayor edad que en los jóvenes.

I4 No basta la resina sola para esta curacion, pues es sola una parte del medicamento; y para que sea completo se le agregan los polvos de mates, que se ponen sobre ella despues de hecho el parche. Estos mates son unas pepitas del tamaño de avellanas, pero chatas de los dos lados, duras, tersas, de un color roxo, hermoso, y por el uno de los dos lomos tiene una raya negra: los produce un arbusto pequeño, y los montes se hallan llenos de ellos, siendo tan comunes, que sirven para el entretenimiento de los muchachos. Convendria el uso de este medicamento, siendo lastimoso que no se difunda su conocimiento, como impurtante, contra un género de accidente que inhabilita á muchas personas, poniendo. en riesgo sus vidas, sin libertarse de tal peligro las de la mayor gerarquía.

I5 Entre la muchedumbre de plantas que da aquel clima cálido y húmedo, se singulariza una, que es de la especie de los solanos, conocida por el nombre de fraylecillo, cuyas hojas sirven de purgante eficaz, sin causar incomodidades á la naturaleza: es tambien cmética; $y$ sobre el medo de operar hay en aquellas partes la vulgaridad de que, segun el modo con que se arrancan las hojas, así operan; si se desgajan, tirándolas hácia abaxo, pretenden que obre por la cámara, precipitando los humores que disuelve; y si es tirándolas hácia arriba, por el vómito. La tienen por eficaz desostruyente, y la atribuyen ademas la propiedad de ser buena para la fecundidad en las mugeres estériles, sobre cuya virtud se refieren algunos 
casos. Dícen los que la han usado por purgante, que no pide resguardarse el dia que se usa de ella, como se practíca con otras medicinas, y que el efecto que causa es grande. El modo es, cocidas dos ó tres hojas, beberla, ó comer las mismas hojas, ó echarlas en almívar al modo de conserva, ó tambien tomada en polvos. Despues de seca, es tarda en operar, y por esto la toman de parte de noche, para experimentar los efectos en el siguiente dia. Da una frutilla del tamaño de una avellana, con tres divisiones, en las quales contiene otras tantas almendras largas redondas, formando arriba como una coronita; siendo de aquí de donde toma el nombre de fraylecillo. Asimismo es comun fuera de aquella isla en los demas paises calientes de aquellas partes.

I6 Los piñoncillos, cuya planta es tambien muy comun en los climas cálidos, sirven de purgante eficaz; pero estos son demasiado activos, y suelen ocasionar malas resultas.

I 7 Los campos de aquella isla en muchas partes, y con particularidad los que están hácia la Habana, abundan naturalmente en la yerba de añil; pero las gentes de allí no la aprovechan, sin faltarles el conocimiento de su utilidad, pues tienen el exemplar de haber enriquecido á cierto extrangero que se estableció en aquella ciudad, el qual, con mas aplicacion que los naturales, estableció una manufactura en un sitio que no tenia dueño, $v$ era silvestre, y haciéndola cortar de los campos, le fructificó sobresalientes utilidades. Este añil es de mejor calidad que el que da la Luisiana, sin embargo del cuidado con que se siembra y cultiva. En aquel clima da tres cortes, que se hacen en el verano: la silvestre de la Habana se seca en el tiempo caluroso, y se reproduce en el de las lluvias.

18 Ia calaguala y la cancbalagua, mas conocidas M 
ya por sus virtudes en Europa que ahora veinte años, son producciones de aquellos inhabitables pináculos de la cordillera, doride la nieve raras veces en el año dexa descubrir la tierra. Hay otra yerba llamada culén, que crece en las alturas del reyno de Chile, cuyas virtudes no son ménos recomendables que las anteriores. Esta es una planta de hojas piqueteadas, al modo de las del peregil, de un color verde obscuro: sus virtudes son tan generales, que la aplican con buen éxito á diversas indisposiciones: es esromacal sudorífica, pero con particularidad es muy favorable para las dolencias ordinarias de las mugeres; siendo tal su eficacia, que las que padecen retenciones periódicas, flatos, y otros accidentes histéricos, curan felizmente, por lo que hacen allí mucho caso de ella.

I9 Ha hecho notable pérdida la Botánica en la retardacion del regreso á Europa del Profesor de la Real Academia de las Ciencias de Paris D. Joseph de Jusieu, que en el año de I735 pasó, en compañía de los Académicos de ambas Naciones, con el cargo de exâminar lás plantas particulares de aquella parte del mundo; pues hubiera podido ilustrar la Historia natural con noticias muy nuevas y útiles, habiéndose esmerado con la mayor aplicacion y penalidad en correr de un cabo al otro el Perú en sus dilatadas distancias; pero un conjunto de accidentes imprevistos malográron las esperanzas que debian fundarse en su sobresaliente aptitud y diligencia; pues habiendo determinado, con el deseo de acrecentar sus observaciones, y el motivo de las guerras que sobreviniéron desde los años de I74. en adelante con la Inglaterra, pasar de Lima, donde se hallaba, á Buenos Ayres, para de allí transferirse al Brasil, y hacer su vuelta á Europa baxo de bandera segura; hecho ya la mayor parte del viage, le sobrevino que 
$S E X T O$.

un sirviente que le habia asistido mucho tiempo, y. de quien tenia onfianza, por robarle el dinero, y las cosas de algun vialor que llevaba, aprovechando la ocasion mas oportina, se le desapareció con la petaca, que contenia el principal tesoro de su trabajo, consistiendo en los Herbarios que habia formado, y los Quadernos de las descripciones de plantas, y otras cosas que tenia observadas: y aunque desde luego se diéron eficaces providencias por los Gobernadores y Jueces para descubrirlo, no se pudo encontrar luz de él, dexándose inferir que tomaría el camino para alguna parte del Brasil. Viéndose despojado del fruto de sus tareas, y que era vergonzoso venirse á Europa sin las noticias que se esperaban, que su naturaleza se hallaba cansada, y no estaba capaz de volver á emprender el trabajo que habia hecho ántes para formar nuevas relaciones de Historia natural, resolvió retroceder á Lima, donde se mantubo haciendo vida privada, entregado á la lectura y exâmen de algunas plantas que se le proporcionó; pero al tiempo de estarse escribiendo esta obra se supo haberse regresado por la Habana, y que habia llegado á Madrid, con lo qual debe esperarse que hará publicar las noticias y observacio. nes que pudo practicar en el tiempo que se detuvo.

20 La coca es planta muy comun en los territorios altos de aquella parte: el mods de usarla es con la tierra llamada toccra, ó llipta, que es una pasta que componen á manera de bollos de chocolate, aunque algo mayores y del inismo color: estos son preparados con las cenizas de la mizorca del maiz sin granos, y la de algunas otras plantas silvestres, abundantes de sales, lo qual amasan junto, y queda duro quando está seco. Las coqueras, que son por lo regular Indias, ministran graciosamente este ingredicnte en proporcionada cantidad á los que se la com$\mathrm{M}_{2}$ pran, 


\section{2}

ENTRETENIMIENTO

pran, como que sin él le falta la mejor sazon á la yerba. Es muy grande el aprecio que los Indios hacen de ella, y no trabajarian con gusto si los faltase: ántes de dar principio se sientan á prepararla, á lo que llaman acullicar, y poniéndose en la boca una buena porcion, con un pedacito de la toccra la van humedeciendo y reduciendo á una pelota: quando la tienen bien amasada la sacan y ponen en la bolsa ó saquillo en donde guardan la coca, y tomando otra porcion hacen con ella lo que con la primera: esto lo repiten hasta tener cinco ó seis bolas, que son las que consumen en dos ó tres horas de trabajo. Luego que se les acaban vuelven á acullicar para seguir adelante con la obra: cada bola la mantienen en la boca todo el tiempo que sienten el gusto áspero y fuerte de la hoja; y quando le falta, la arrojan, y toman otra. Usan de unas bolsas hechas del pellejo entero de algun animal pequeño, como de zorrillo, ú otro equivalente, y en este traen, la coca y la toccra pendiente de la cintura, al modo que en Europa los que usan del tabaco traen el de polvo en caxas, y ti de humo en bolsas proporcionadas para él.

2 I Es muy comun allí la yerba que llaman bediónda, cuyo nombre dice bien con su propiedad, porque el olor que despide tocándola ó moviéndola, es muy fastidioso é incómodo: es una de las muchas especies de solano que hay; y esta de que se trata crece en arbusto bastante grande. Usan de ella para varios medicamentos; y en la Luisiana, donde tambien es muy comun, para matar las lombrices, siendo eficaz para ello. Esta no prevalece en los temperamentos mas frios, pero sí en los que son moderados y cálidos, y así viene á ser comun en ambos.

22 Parece, por lo que la experiencia enseña allá, que 
que el ajo es natural del temperamento frio: en aquellos parages altos no se cultiva, y es una de las yerbas nocivas que inficionan las tierras, porque en las que empiezan á nacer propagan tanto, que se inutilizan para producir otras cosas: aun la vecindad es incómoda por el olor fuerte que exhalan; así este género no cuesta allí mas que el trabajo de cogerle.

23 La naturalezá tiene reservadas sus prerogativas para distribuirlas en distintos paises, y no a todos los hace igualmente partícipes de unas propias cosas. Los de la Luisiana, hácia la parte de su medianía, son abundantes de viñas naturales, y crećen con tanta lozanía y perfeccion, como si se hubiesen plantado á mano, y estuviesen cultivadas. De este modo se reconocen en el territorio que media entre los Opelusas y los Natchitochas, cuya distancia es de 40 leguas. Las viñas forman á modo de cepas, extendiendo los sarmientos con sobresaliente vigor. En principio de Mayo se hallaban cargadas de racimos de uva en algo mas que esquilmo, y señales de dar buen fruto y abundante; pero no llega á madurar, porque la muchedumbre de venados, gamos y osos que hay en aquellas partes, las consumen ántes de tomar sazon.

24 Las plantas de fresas son igualmente naturales en aquel territorio, y el fruto es tan bueno como el que se coge en los jardines, dándole la cultura regular. En el reyno de Chile, en las campiñas de la Concepcion, que están en poca más altura meridional que los campos expresados de la Luisiana, son igualmente naturales estas dos plantas, hallándose esparcidas por ellas en la misma forma que atlá. En esto se ve la igualdad que tienen los dos paises, sin embargo de la mucha distancia que media entre ambos; pero no se ven en el territorio de la parte alta del Perú, donde reyna el temperamento frio, 


\section{4}

ENTRETENIMIENTO

ni en la que goza mas templado, sin exceder en estos dos extremos: debiéndose colegir de ello, que estas plantas no solamente necesitan de un grado de calor moderado, que alterne con el frio del invierno, y lo mas cálido del verano, sino una atmósiera proporcionada, cuyo ayre no sea tan sutil y ligero como el que reyna allí.

25 Los campos de la Luisiana son muy fértiles y abundantes de plantas : circunstancia que debe experimentarse en ellos, porque el clima les favorece, y las alternaciones de lluvias y soles los fecundizan. Son asimismo vírgenes, no habiendo tenido cultura alguna, y con esta circunstancia crian lozanamente aquellas plantas que son propias de ellos.

26. El zarzafrás es árbol muy comun, y de aquellos que contribuyen á hacer espesos é impenetrables los bosques. El capiler, que vulgarmentz llamamos culartrillo, se produce abundantemente hácia las partes altas del Misisipi, por los llinoeses, y mas hácia el Norte; siendo el de allí estimado con particularidad por la eficacia de sus virtudes.

27. En las partes mas al Norte de la Luisiana, hácia lo interior del rio Misuri, que va á confinar con Santa Fe en el reyno de Nueva España, y por el Norte de esta Provincia se halla la planta llamada por los antiguos mandrágora, de la qual hablan bastante los Historiadores de aquellos tiempos, haciéndolo con particular estimacion. De esta, dicen los tratantes de la misma Luisiana (que son los que se introducen por aquellos parages), observarse en ella no solo la semejanza que tiene á la figura humana, sino que se distinguen los dos sexôs; y aunque conducen algunos trozos, no se percibe por ellos la semejanza que pretenden atribuirle. Hay autores. que aseguran haberla en el Canadá, lo que no tiene dificultad, porque los dos parages se dan la mano. uno 
uno con otro; y de haberla en alguno de ellos, es regular que participe el que se halla contiguo. En la Provincia de Pequin, en la China, las hay, bien cue, segun la opinion mas accrtada, no es allí donde se cria, sino que las llevan de la Tartaria. Llámanla los Chinos ginseng, aludiendo á la figura de hombre que tiene; y los Tártaros orbota, que significa la primera de las plantas, dándole este nombre por razon de las excelencias de sus virtudes. Son tantas y tan particulares las que se le atribuyen, que se mira entre ellos con el mayor aprecio. Las principales consisten en restablecer los espíritus vitales, y vigorizar las fuerzas quando se hallan desfallecidas por alguna fatiga del cuerpo; y entre otras muchas que se le apropian, dicen que prolonga la vida en los ancianos, y la renueva en los que padecen achaques. Sin embargo de ser cara en donde se coge, por venderse á peso de plata, no lo es tanto como corresponde á las grandes virtudes que se refieren. El primer descubrimiento que se hizo de ella en la Luisiana fué en el año de I768. Aunque no se dé crédito á todo lo que ponderan las relaciones Chinas, y las que hacen los Tártaros, sería muy digna de que se mandasen recoger algunas porciones para hacer experimentes en la Medicina, pues con una parte que se verificase de lo que se relaciona, sería bastante para deberla estimar cntre las cosas mas preciosás.

28 Lo que falta de frondosidad á los territorios de la parte alta del Perú, tiene de abundancia la Luisiana en árboles de muchas especies: la tierra está tan cercada de ellos, que la hacen impenetrable, son de una elevacion muy alta, y en todo lo que corre aquel rio no se descubre espacio que no esté pobladísimo de ellos, y con bastante distancia hácia 10 interior. Como esto sucede las orillas 
96

ENTRETENIMIENTO

de los rios y sus inmediaciones, y son tantos los que corren por aquellos dilatados paises, dando el caudal de las aguas al Misisipi, se propagan á correspondencia los bosques, y solo algo retirados de los rios es donde las tierras parecen descubiertas, formando praderías dilatadas.

29. Los árboles mas comunes son los que llaman siples (cuya madera es muy semejante á la del pino del Norte, y por lo tanto la aplican á hacer tablazon y viguería), el laurel, el roble, el alámo, el sáuce y el pino, siendo varias las especies en que se divide cada una de estas. Otras dos especies de árboles se encuentran allí, que parecen ser particulares de aquel pais: la una de estas llaman pacanos, que es un género de nogal de mas corpulencia que ellos, pero en madera y hoja muy semejante : el fruto es en el gusto parecido al de la nuez, mas delicado y fino, con ménos partes aceytosas : en la figura es diferente, y se parece á los dátiles, siendo en el tamaño quasi el mismo, ó poco menor; la cáscara es muy delgada y lisa, sin las escabrosidades que tiene la nuez. El otro es el árbol de cera; este es mediano, acopado, y da una semilla en forma de racimos, que es con la que se hace la cera. El modo es, quando tiene la madurez regular, hervirla en agua, con la qual se extrae una parte grasosa, que recogida se coagúla, y es la cera; su color es verdoso obscuro, y la luz que hace tira á este, no siendo tan clara y viva como la de cera de abejas, ó la de esperma, de que se fabrica mucha en la Nueva Inglaterra. Le dan el nombre de cera por la consistencia que toma, sin derretirse, ni ablandarse con calor moderado, como sucede con el sebo: propiamente no es cera, sino una materia oleosa crasa, que toma consistencia, y forma cuer. po duro, diferenciándose en esto de los otros acey, 
tes de que abundan ciertas semillas, como la del lino, cánamo, nabo, colsac y otras distintas. Suelen beneficiar esta cera extrayendo de ella con repzticion de evoluciones las partes mas impuras, con lo qual pierde el color verdoso en mucha parte, pero sienpre conserva algun viso, que no dexa equivocacion de ser materia vegetal.

$3^{\circ}$ Los árboles del Misisipi en la vigorosa frondo* sidad que manifiestan quando se ven vestidos de hom jas, se reconocen poblados de una produccion ó planta extraña, que en la estacion del estío, quando se despojan de aquella, queda mas visible, y los afea, representándolos como viejos y en el último estado de decadencia. Esta planta, que allí conocen por el nombre de barba Española, se compone de un conjunto de filamentos delgados de color ceniciento obscuro, y dividida en multitud de ramificaciones fiexîbles, parece como una maraña de hilos que cuelgan de las ramas en tanta abundancia, que lo pueblan por todas partes: quando se hallan vestidos de la hoja, y adornados con el verdor de esta, no se percibe tanto; pero luego que con el estío se despojan de ella, se ven las ramazones, y hasta el tronco desfiguradas con ellos, manifestando tristeza. Esta planta s:arrayga en la corteza del árbol, y vegeta: sus semillas, llevadas por el ayre, van á los otros, siendo este el modo de propagarse, y de hallarse tan cundida. Sírvense de ella para hacer colchones y otros reenchidos, á cuyo fin la ponen á secar y la varean, con cuya diligencia despide la cortecilla, y queda el corazon, que es de un color negro: en esta forma engaña, porque parece cerda rizada, no distinguiéndose de ella ni en el color ni en el grueso, y los que no están hechos á verla la equivocan fácilmente. En esta y otras particulares producciones se reconocen los juegos de la naturaleza, que entre la distante variedad de sus do$\mathrm{N}$ tes 
tes imita con ellos lo que parece mas disonante. En varias partes de los paises calientes de América, el arbol llamado ceibo imita con su fruto la lana de los ánimales, y sirve para muchos usos de los que se aplica aquella. El algodon es una especie de seda finísima y suave. La piña de Indias es en la figura parecida á la que dan los pinos, $y$ en la sustancia totalmente diversa: los árboles de cera la dan, como se ha dicho, semejante á la que laborean las abejas, y la que llaman barba: siendo una produccion vegetal, se toma por las clines de los animales.

3 I Entre la diversidad de plantas que son comunes en aquel clina, puede mirarse como especial la que llaman viperina: esta es de la clase de las menores, y se encuentra hácia las partes altas del Misisipi: su virtud es muy conocida para libertar de malas resultas á las mugeres despues que han parido, y la usan en estos casos con buen éxîto; no ménos que para purificar la sangre, y corregirla en el retroceso que hace la leche al tiempo de extraviarla el curso natural, para que se les seque. A esta semejanza hay otras muchas que conocen los naturales, adequadas para varias enfermedades; y así se ve que se curan con ellas aun de las mas peligrosas y difíciles. Sería muy conveniente que en cada pais se hiciese un catálogo de las plantas y sus virtudes, con el modo de aplicarlas, para que las conociesen y se aprovechasen de ellas en los que no las hay.

$3^{2}$ Otra planta menor hay no ménos rara que las antecedentes : esta, quando se halla en sazon, que está florida, tiene la propiedad de coagular el agua, al modo que el cuajo ó la flor del cardo lo hacen con la leche, quedando aquella con la misma consistencia quo esta, y coagulada no es perjudicial á la salud: es. bastante abundante por aquellos campos.

33. El añil, como se ha dicho, es de las plantas que 


\section{$S E X T O$.}

que se cultivan en los territorios de la lusian que se cultivan en los territorios de la Lusiana: del mismo moáo lo son el tabaco y la caña de azúcar; cl primero de estos hace mejores progresos en su vesetacion que la segunda, bien que su calidad no iguala con mucha distancia al de la isla de Cuba, ni tiene la fortaleza y olor que el de la Española. El azúicar es de inferior calidad, y por la misma razon que abunda de humedad el pais, y que sus colores son repentinos, no cuaja á proporcion de lo que abunda en xugo la caña. Esta se siembra de un año para otro, y no tiene mas que un corte, originado de sobrevenir los frios grandes del invierno despues de haberse hecho: en esto es diferente de lo que sucede en la parte baxa del Perú, llamada Valles, y en las quebradas de la alta, pues en ambas tarda desde que se siembra con brevedad, dos ó tres años, hasta que se corta en madurez; y despues de este primer corte da otros dos en los años consecutivos: siendo el tercero el que llaman soca, que sirve para volverla á plantar. Por esto en aquellas haciendas de caña, que en unas partes 11 aman Trapiches, y en otras Ingenios, con alusion á la máquina donde se mucle, tienen quatro suertes, que plantan en distintos años, y cortan en cada una la que corresponde estar madura, de cuyo modo nunca cesan de moler, ni de fabricar azúcar. Contribuye á ello la poca diferencia que hay en el temperamento entre el invierno y el verano, y, por ello son igualmente favorables para que el azúcar cuaje. No sucede así en la Lusiana, en la Habana, ri en los otros parages donde son grandes las diferencias de los dos temperamentos, ó donde reyna con exceso el calor, porque entónces no cuaja con perfeccion, y solo muelen en aquella coyuntura que es favorable al intento.

34 El tabaco, sin ser de la mejor calidad, es regular. El consumo que tiene es en andullos ó rollos para hacer rapés, y en hoja para fumar: no tiene $\mathrm{N}_{2}$ mus 
mucha extraccion, y por esto son moderadas las cosechas: es no obstante superior al de las colonias de Virginia y resto de la Nueva Inglaterra, y al que se culiva en Holdnda y en las Provincias SeptentrionaJe; de Alemania: por esto si se le procurase dar salida no dexaria de tener aceptacion, y pudiera ser uno de los ramos de comercio considerables de aquel pais, al modo que lo es el de Virginia, Brasil y otras partes.

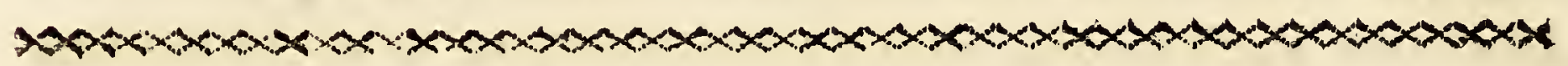

\section{ENTRETENIMIENTO VII.}

\section{De los animales, y sus particularidades.}

I Despues de haber explicado lo correspondiente á plantas, es consiguiente seguir con los animales, $c u$ ya miteria ministra un campo sobradamente extenso, si se hubiese de tratar con la expecificacion correspondiente; pero se ceñirá su noticia á lo mas particular y digno de ser sabido, para que sirva de ilustracion al conocimiento mas completo de lo que se registra en el mundo. La curiosidad no siempre se contenta con la relacion de las cosas que están fuera de los límites de nuestra vista, sino que desea conocer sus circunstancias particulares, los modos de que pueden ser útiles, y los usos á que las destina la industria en cada pais: por esto, quantas mas luces puedan adquirirse de ellas, serán mas auxílios para el logro de estos fines, y el de comprehender las obras de la naturaleza en quanto alcanza el entendimiento.

2 Entre los animales particulares de la tierra alta del Perú son los mas comunes las vicuñas, alpacas y Jlacmas; tres especies, que en la extructura se diferen- 
cian poco, pero se distinguen en el tamaño, en las propiedades, en el color y lo largo de la lana. Sobre estos animales hay varias cosas que decir.

3 Las alpacas son en la especie semejantes á los guanacos, y la mayor diferencia consiste en la lana, que la de este último es tosca, de color pardo, y de poco uso, lo que no sucede con la de las alpacas. Estas y las llacmas, que tambien llaman carneros de la tierra, se domestican, lo que no sucede con la vicuп̃a, que siendo de las tres la de ménos cuerpo, de figura mas ventajosa, mantiene siempre con lo arisco la propension á buscar la libertad; suele por curiosidad tenerse alguna en las casas, que por no ser animales dañosos no hacen mal, pero no se sujetan á la carga como los otros, ni se olvidan de los campos que la naturaleza les dió para correr sin sujecion.

4 Andan en tropas ó manadas mas ó ménos crecidas, pero no lo son tanto que pasen de 20 ó 30 . Su mansion es en las Punas desiertas y frias, donde crece el icbu ó pajón, de que se alimentan : es animal muy sentido, que no dexa se le acerque la gente: corre con tanta ó mas ligereza que los gámos; y no viéndose perseguido, está con sosiego paciendo lo mas del dia. El son que hace con la boca es agudo, á modo de silvido, no correspondiente al cuerpo; y estando en su libertad lo repite á menudo, teniendo mas semejanza al silvido de algun páxaro que al ruido de animal quadrúpedo. No es fácil cazarlo con la escopeta, ni detenerlo con los perros, por la ligereza con que corre. Es ayroso de todos modos, pero en su libertad mas, por la disposicion y señoría con que lleva la cabeza levantada, y haciendo con el cuello como una $S$, sin descomponerla aunque corra velozmente. Lo que se aprovecha de él es la lana por su finura y suavidad: si no tuviera el defecto de ser floxa pudiera sacarse mayor ventaja de ella para distin- 
tos rexidos y sombreros, cuyo defecto le quita parte del valor que tendria.

5 No siendo facil cazarlas con la escopeta ni con perros, hay orro medio, que es causa de su destruccion : este es el de hacer chacos, voz que en el idioma Indio significa union, ó compañía de muchos para alguna cosa. Es la vicuña animal muy tímido; qualquier ruido lo azora, y con facilidad se espanta: con este conocimiento disponen cerrar una cañada con alguna cuerda que la circunde, dexando un corral bastante espacioso, y con una sola entrada: ponen la cuerda en aitura proforcionada, de modo que corresponda á la medianía del pescuezo de las vicuñas, y en pequeñas distancias cuelgan unos pedazos de lana colorada ó de ctros colores, para que se muevan con el ayre. Antes de disponer este cerco tienen exâminado el sitio donde pacen algunas manadas, y lo forman lo mas cercano á ellas. Estando preparado hacen una especie de batida, ayudáncose la gente de algunos perrillos que tienen industriados para el intento, y llevan acosadas las vicuñas, hasta que logran meterlas en el cerco: ellas, viéndose encerradas, procuran escapar, pero advirtiendo los colgajos, se espantan, sin determinarse á saltar por encima de la cuerda, ni á humillar el cuello, para pasarla por debaxo. En esta forma entran los hombres que las enlazan y matan, desollándolas para conservar la lana en los pellejos. Por lo comun son Indios los que se ocupan en este exercicio, ó algunos mestizos: es duro y penoso por hacerse en las Punas rígidas, cuyos parages son despoblados, sin que en la inmediacion ni en algunas leguas se encuentre poblacion, ó alvergue donde recogerse. Necesitan estar meses en él para hacer caceria de algun fundamento: la carne de las vicuñas y el maiz que llevan les sirve de alimento; y quando el tiempo es malo, que nieva, ó que los vien- 
tos son muy recios, se alvergan al respaldo de algunas peñas, ó en lo abrigado de alguna cañada.

6 Entre las manadas de vicuñas suelen encontrarse algunas alpacas; pero tambien se ven otras de estas, aunque no en tanto número como aquellas. Estos cazadores no separan la lana de los pellejos, porque si lo hicieran no se los comprarian, á causa del fraude que se ha solido hacer en mezclar la de alpaca con là de vicuña, siendo fácil por ser esta de un mismo color, aunque mas larga, y no tan suave y fina. Los tratantes que la compran en pellejos, la mandan separar, y despues la empaquetan para remitirla á España.

7 Por esta causa matan quantas entran en el chaco, hembras y machos, de donde resulta la diminucion de la especie, y esto sin necesidad, porque estando encerradas podrian trasquilar las hembras, y minorar el número de los machos, segun se hacia en tiempo de los Incas, con cuya providencia se multiplicarian, y cada vez habria mas abundancia de lana, quando al presente cuesta trabajo encontrarlas. Las alpacas y los guanacos son de las tres especies la mayor; y conservando una semejanza á la vicuña, son feas: su pescuezo largo y grueso, pero no en figura de $S$ como la vicuña, sino quasi derecho, levaritado arriba , perpendicular á las espaldillas: la cabeza y parte alta del cuello poblada de lanas largas y espesas, lo que no sucede á la vicuña; y el resto de las lanas tambien es largo, particularmente en los brazuelos y hácia el vientre. Se domestican como las llacmas y la alpaca; sirve para cargar, pudiendo llevar á proporcion del cuerpo mayor peso que ellas; lo que no sucede al guanaco.

8 El animal mas útil para los Indios, y que se acomoda mas á su carácter, es la llacma ó carnero de la tierra: con él hacen toda suerte de carguíos, no 


\section{4}

ENTRETENIMIENTO

solo en las minas, sino para transportar lo que se ofrece de unas partes á otras. La estimacion con que le miran pasa los rérminos de la racionalidad, y manifiesta su natural ignorancia. A todos los animales domésticos tienen un género de afeccion, que no se ve en otras gentes, pero es mayor con las llacmas, y así lo dan a entender por las demostraciones que hacen.

9 Antes de empezar á servirse de ellos para la carga hacen un festejo, que á lo que indica la exterioridad, es como celebrando tenerlos por compañeros. Este se reduce á traerlos al cercadito de su cho$\mathbf{z a}$, engalanarlos, poniéndoles muchas cintas y colgajos de seda ó lana en la cabeza: preparan porcion de chicha, aguardiente y maiz tostado; y convidando á los Indios, sus amigos, concurren todos con sus mugeres é hijos en el cercado ó corralillo donde están las llacmas: tocan sus tamborilillos y fiautillas, y empicza la danza, que dura un par de dias, continuándose en la noche como en el dia por intervalos. Quando están fatigados lo suspenden, y vuelven á seguir luego que toman nuevos brios, ó que los vapores de la bebida se disipan. De tiempo en tiempo van á los animales, que por lo ordinario se hallan recogidos en uno de los rincones del corral, y los abrazan, haciéndoles mil agasajos; les presentan las totumas, ó calabazas de chicha y de aguardiente; y aunque no las beben, se las aplican al hocico, quedando satisfechos con esta demostracion: tambien les hablan en su lengua, diciéndoles mil cosas de amistad y cariño, así como pudiera hacérse con una persona con quien se tratase de algun género de alianza : concluido este festejo, que es como anuncio de la amistad, empiezan á servirse de ellos, pero sin quitarles los adornos y galanerías que les pusiéron.

Io. Antes de haberlos puesto á la carga los tratan con 
SEPTIMO.

con tanta moderacion, que no es regular ni apurarlos en las marchas, ni castigarlos, acomodándose al paso de ellos, y se sirven del silvido para gobernarlos. Con facilidad se hacen á la carga, aunque no dexa de haber algunos que lo resisten; pero esto es de un modo que se conoce no inclinarse á hacer dano, y que su resistencia es por no sujetarse á llevar el peso que les intentan poner. No come este animal mas yerba que la que coge del campo, y se puede pasar sin alimento dos dias, y aun mas tiempo quando no trabaja. Si llega á cansarse, y se tira en el suelo, sea por haberle dado mas camino del que puede sobrellevar, por estar necesitado de alimento, ó por haberle puesto mas carga de la que sus fuerzas permiten, no vuelve á levantarse mas, y allí se queda hasta que muere, siendo inútiles quantas diligencias hace el Indio para ponerlo en pié; cuya particularidad es bien rara, por no ser regular en los otros animales, como tampoco el que, domesticándose del modo que se ha dicho, no coma mas que la yerba que pace : por esta razon caminan tanto de noche como de dia, y van cogiendo la yerba que encuentran en las inmediaciones del camino; pero sin embargo de ello les dan descanso en distintas horas, y en ellas, despues de haber pastado, se echan en el suelo para rumiar y recuperar nuevas fuerzas, manteniéndo siempre la cabeza alta y el cue110 derecho hácia arriba. El modo de echarse tambien es particular, diferenciándose de los otros animales : para ello se hincan lo primero de rodillas, y encorvando las piernas las acomodan debaxo del vientre una por cada lado; en esta forma queda el cuerpo derecho, lo mismo que los que están en pié, el espinazo en medio, y no se les ve pierna ni brazo, porque las encubren enteramente con el cuerpo.

I Q Quando empiezan á cansarse, ó que se encoO le- 


\section{6}

ENTRETENIMIENTO

lerizan, hacen un chillido agudo, distinto del de las vicuñas, á modo de quejido, pero diferente quando es por cansancio de quando están embravecidos. Yendo cargados, sin tener cansancio, llevan en continuo movimiento la cabeza, mirando con señorío á uno y otro lado, como para registrar la campaña. La lana es basta respecto de las vicuñas, y alpacas, y la aplican á ciertos usos en que no se requiere fina: tienen variedad en los colores, porque hay algunas manchadas de blanco y acaneladas: otras de blanco y negro, sucediendo á los guanacos lo mismo; pero lo mas regular es el color de canela, ménos subido que el de las vicuñas. En los tiempos presentes no hay de estas llacmas montaraces, sien-. do manadas domésticas las que se encuentran en las Punas, en cuyos parages las tienen sus dueños para que procreen con libertad en el clima y pastos que: son propios para ellas; de suerte que estando allí sin encierro ni sujecion, no se hacen ariscas, como lo son siempre las vicuñas.

I Así como las plantas tienen sobre la tierra sus distritos particulares para vegetar, sin propagarse por toda ella con igual generalidad, tienen igualmente los animales sus domicilios señalados por la naturaleza para procrear y mantener la especie, sin pasar á otros territorios distintos de los que les destinó. Las llacmas son comunes en el reyno de Quito; y las vicuñas son particulares de este último en el del Perú, sin hallarse en el otro, no obstante ser todo un continente, ser muy uniforme el clima en la sutileza del ayre y en los pastos, habiendo en uno y otro pais Punas con el mismo grado de frialdad, siendo la yerba comun el ichu, y la qualidad del ayre, en quanto alcanza á percibirse, la misma. Así hay motivo de creer que concurra alguna causa no perceptible á los sentidos por donde se 
distíngan las Punas, y parte alta de aquella tierra, en la Equinocial, y grados inmediatos de la otra, que está mas apartada, y que esta es la legítima razon de que los animales, que son naturales de la una, no puedan prevalecer en la otra.

I 3 Tal vez aquella causa que ocasiona el maréo en las Punas del Perú, cuyos efectos no se experimentan en las del reyno de Quito, puede variar lo esencial del clima en tanto grado que sean diversos, sin embargo de ser iguales en la dilatacion del ayre, en la frialdad, y en las yerbas.

I4 Al contrario sucede con la casta de conejos silvestres: los hay con abundancia en el reyno de Quito, siendo de la misma especie que los de Europa en todas sus circunstancias de tamaño, figura, color y gusto; y en el reyno del Perú no los hay, porque aunque no dexa de verse la raza de los que llaman caseros, es distinta de la otra, y estos solo se ven en las casas donde la curiosidad los mantiene. En correspondencia de los conejos que faltan en el Perú, hay otra casta de animales que llaman viscacbas, de que el reyno de Quito carece enteramente: son en la figura y en el color del pelo lo mismo que el conejo, y se diferencian de él en que tiene rabo largo, poblado de pelo esponjoso, al modo de las ardillas: hácia el nacimiento es muy ralo, y hácia la punta espeso y largo: no lo traen vuelto hácia la cabeza como la ardilla, sino tendido quasi horizontalmente: las articulaciones son menudas y escamosas. Se esconden en los agujeros de las peñas, $y$ en ellos tienen sus madrigueras, no haciéndolas en la tierra como los conejos: allí están juntas muchas, y lo mas del tiempo se les ve sentadas sin comer: se alimentan de las yerbecillas y de los arbustos que se crian entre las mismas peñas: son de mucha viveza; su huida no la tienen en la carrera, si- 


\section{8}

no en la prontitud de buscar la concavidad, y meterse en ella: de ordinario lo executan quando se sienten heridas, y por esto el modo de matarlas es tirándolas á la cabeza, pues aunque reciban el golpe en otra parte, y les hagán mucho daño, no dexan de ir á morir á lo interior de la madriguera. Tienen la particularidad de que luego que mueren se les cae el pelo, y por esta razon, aunque es mas suave y algo mas largo y fino que el del conejo, no se pueden aprovechar sus pieles para los usos comunes. La carne es blanca, pero no de buen gusto, por ser fastidiosa, con particularidad en algunos tiempos, en los que del todo repugna.

is La casta de los conejos parece ser una de las que mas cunden en la tierra, siendo raro el pais en donde no se encuentren de un modo, ó de otro. En la Luisiana los hay, y aunque de la misma especie que los de Europa, son algo mayores, como en un medio entre la liebre y el conejo : no hacen madrigueras en la tierra, y en su lugar buscan los árboles viejos que tienen el corazon podrido, y si hallan huecos en ellos se recogen, internándose hasta 10 mas alto que pueden penetrar; por esto el modo de cogerlos es haciendo humareda en la parte inferior, y cerrando las correspondencias de arriba, para que la fuerza del humo los sofoque, y desprendiéndose caygan. Los perros con que se les persigue dan indicio del árbol á donde se acogen los que han sido perseguidos. Puede inferirse de aquí, que la propension de hacer madrigueras debaxo de tierra no es general en todos los paises, y que varía segun las circunstancias. La abundancia de árboles en la Luisiana, en la extension de aquellos bosques, proporciona muchos, que con la vejez están huecos, y este animal se aprovecha de ellos para su guarida, evitando la humedad de la tierra y las inunda- 
ciones; que son regulares alli por la gran llanura del terreno y la poca elevacion que tiene respecto de los rios.

16. La parte alta de la América Meridional es poco abundante en especies de animales silvestres; pero las que hay no se sabe que sean comunes á las restantes del mundo. Vicuñas, alpacas y llacmas no las hay en la Luisiana, ni en todo lo que se extienden los reynos de Nueva-España, ni fuera de la América; pero en el Perú no se ven ciboros, martas, castores, y otros de pelo fino: en ambos paises hay conejos, pavas montesas, corzos, gamos y osos, aunque con algunas diferencias, que las ocasionan los climas; y así hay unos animales que son comunes, y otros particulares á cada territorio, sin que se tengan noticias de que la falta presente proceda de haberse extinguido con la sucesion de los tiempos los que no hay, teniendo el clima proporcion para mantenerlos.

I7. El ciboro es animal propio de la Luisiana y de las partes septentrionales de Nueva-España: comunmente le dan el nombre de vaca silvestre, y los Franceses le llaman buey silvestre. Es parecido al toro ó vaca domésticos en la figura, tamaño y sabor de su carne, diferenciándose en tener una lana fina rizada y corta en lugar de pelo. Hay mucho consumo de su carne, y la usan salpresada, no pudiendo conducirlas de otro modo, por hacerse las cacerías muy léjos.

I8. En los paises de Buenos Ayres, curyas espaciosas llanuras son abundantísimas de pastos, hay, como se sabe, crecidas tropas de vacas silvestres, que no reconocen mas dueños que los que van á niatarlas; pero estas son de la misma especie que las de Europa, sin que se reconozca la de ciboros, cuya falta no puede atribuirse á la calidad de los pastos 
ni al ayre, porque en donde se mantienen las unas con tanta abundancia, desde que se hizo la conquista, podian haberse hallado los otros, como sucede en las partes del Norte. Débése admirar en esto, como en otras cosas, la providencia del supremo Autor, que dispuso no fuesen comunes unas mismas producciones en todas las partes de la tierra, para que cada pais tuviese en las que le son propias el dote que le correspondia, y con el incentivo de la variedad se hiciesen comunicables.

I9 Uno de los animales comunes es el oso, que lo hay en la parte alta del Perú, en la América Septentrional, y en otros muchos paises del mundo antiguo, pero en la Luisiana abunda mas que en otras partes: alli se hacen crecidas matanzas de ellos; y el aceyte que se saca de sus mantecas es el que se gasta para condimentar los alimentos. La carne se aprovecha; pero lo principal son las piernas y brazuelos, de que hacen jamones al modo de los del puerco.

20 Es tambien ordinaría en aquellos bosques la ardilla, que no solo sé encuentra en los parages montuosos de la América, sino en las demas partes de la tierra. En la Luisiana hay una casta enteramente negra, sin exceder en el cuerpo á las del color regular: estas se hallan hácia la parte alta del Misisipi, y no son comunes. Las mas particulares, y que no se ven en otros paises, son las voladoras, las quales hacen un vuelo como de la distancia de 20 varas, ayudándose para ello de dos membranas que les salen por los costados del vientre, y se unen con las piernas y brazos: para volar las extiende, y así practíca los tránsitos de unos árboles á otros, midiendo lo que puede sostenerse sin caer con la distancia que hay entre ellos. Son algo mas pequeñas que las ordinarias, pero parecidas á ellas en el penacho que 
forma la colá, en la estructura de la cabeza y cuerpo, y en la agilidad y prontitud de estar siempre en movimiento.

2 I En la parte baxa de la América Meridional, conocida con el nombre de Valles, no se ven sabandijas ni animales ponzoñosos. Tampoco los hay en la parte alta. La primera goza de un calor moderado en verano, sin participar de lluvias; la segunda de un frio mas ó ménos grande, lloviendo con abundancia; pero hay parages intermedios en donde, sin ser los calores de los mas fuertes, ni participarse de las lluvias de la parte alta, abundan. las sabandijas ponzoñosas, y particularmente las vívoras, cuya actividad es tanta, que su mordedura es mortal, como sucede en Europa. Esto se observa en los valles y cañadas que están al pié de la serranía, entre ella y, los paises baxos inmediatos al mar. A 34 leguas de Lima, por la parte del Sur y del Este, están los valles de las Capillas, de Huaquina, Huanca-conachi, $y$ del Topara, que confinan unos con otros, y en ellos abundan mucho las vívoras, pero á la corta distancia de 4 leguas, sea subiendo la serranía, ó dirigiéndose al pais llano, no se ven, sucediendo lo mismo en el valle de Luna-Guana, cuya situacion es como la de los antecedentes, al pié de la serranía, y distante de ellos cosa de 12 leguas, en el que no hay tales sabandijas; de que se debe inferir, que en la tierra hay alguna qualidad que no se percibe para que prevalezcan en los unos, y dexen de verse en los otros.

- 22. Qual sea esta en los paises que no son montuosos y húmedos como los de Guayaquil, Panamá ó Cartagena, no es facil de averiguar, pero puede atribuirse á que el criarse las vívoras y otras sabandijas ponzoñosas en determinados parages, dimana de ser la naturaleza de la tierra algo pedregosa, y no 
de arena pura, como lo es la de los valles en general.

23 Ostenta la naturaleza por todas partes sus maravillas en la extraña variedad con que colocó las cosas, sin dexarnos penetrar las reglas de su providencia. En la isla de Cuba hay abundancia de culebras; pero su picadura ó mordedura no causa daño de consideracion, como acaece en los otros climas cálidos y pluviosos de la América, y en ella no se ven las culebras, corales, y las cascabeles, no obstante que son tan freqüientes en Cartagena y Tierra-Firme, y que tambien son comunes en la Luisiana, donde se ven de unos tamaños disformes: fuera de estas dos especies hay allí otras varias; las mas ordinarias son de color negro, siendo rara la que no sea ponzoñosa y del mayor peligro. Durante el tiempo frio del invierno no se ven, siendo opinion muy valida, que se mantienen dormidas enterradas en el lodo, pero al calentar el tiempo salen del lecho en donde están, siendo entónces peligroso andar por donde hay yerba, por lo abundantes que son.

24 La circunstancia de ser isla la de Cuba, no parece suficiente motivo para que falten en ella y en las otras sus confinantes los animales ponzoñosos, que pudiéron haberse propagado en ellas, como los que no lo son. Allí son comunes, entre esta clase de reptiles, las culebras de tamaño disforme, que llaman bobas, al modo que las de los rios Orinoco, $\mathrm{Ma}$ rañon, y otros de la América. El insecto, tan general en las Indias, llamado nigua, ó pique, cuya incomodidad es freqüente, como el peligro que se corre despues de la extraccion, si por casualidad se moja el pié en la isla de Cuba, no le hay en la Luisiana. Por el contrario, se encuentran en la provincia de Quito, no obstante la pureza de su ayre, que no permite animales ponzońosos, ni de insectos molestos á la vida. 
25 La parte alta del Perú logra esta prerogativa mas de no participar de su molestia; y aunque la casualidad haga que alguno las lleve sin haberlas sentido, luego que llega á aquellas partes se mueren, y. la naturaleza las hace salir sin diligencia, por separarse ellas mismas de la carne. Posible será que en los valles de las quebradas, cuyos temperamentos son calientes, no falten; pero saliendo de ellos para las partes altas, perecen. Los frios grandes de la Luisiana en los intervalos de invierno pueden ser causa de que no subsista allí este insecto, sí bien hay otro tanto, ó mas pequeño, y no ménos incómodo que las niguas.

26 Las yerbas de aquel pais, al paso que son viciosas, producen con abundancia un insectillo de los mas molestos que se puedan discurrir; basta pisarle para que se pegue á las piernas: llamanle los Franceses bete rouge, animal roxo: es tan pequeño que se necesita tener una vista muy perspicaz para distinguirlo, y con la ayuda del microscopio se reconoce tener la figura de un cangrejo, y que es colorado: se introduce por el cutis, y causa una picazon tan viva, que parece fuego: si se rasca en donde se siente se imposibilita despues el sacarlo, porque se interna en el cutis; con cuya advertencia se procura sufrirla, y se extrae con la punta de un alfiler: luego que sale cesa el ardor; este ocasiona ampollas, que se llenan de agua, y llegan á hacer materia, como sucede con las quemaduras, ó con los cáusticos, lo que es bastante prueba de la actividad que tiene en la mordedura. Parece imposible que un animalilio tan pequeño, que lo es como la punta de un alfiler, pueda hacer mal tan sencille. No es solo en las piernas en donde se introduce, sino en todo el cuerpo, no habiendo parte reservada para él. El renedio para mitigar el ardor es lavar con viP. na- 
nagre la parte donde está; y repitiéndolo se muere, pero nunca es tan pronto que no dure algunos dias.

27 Aquel pais es de los mas pensionados de insectos molestos que puedan verse: las moscas cantáridas son muy comunes, y las garrapatas de monte, que llaman los Franceses pou de bois, piojos de bosque; con dificultad puede andarse por entre ellos sin encastarse. No son estas garrapatas de las grandes que se conocen en otras partes. Su tamaño es como la quarta parte de un grano de trigo, pero los efectos o son ménos que los de aquellas: al arrancarlas de la parte donde se pegan, es necesario tener la precaucion de aplicar aceyte y sebo, ú otra cosa, para que suelten, porque de lo contrario se rompen por el cuello, y quedando la cabeza dentro de la piel causan el propio mal que si el animal estuviese entero, y dura por muchos dias, hasta que con la continuacion de aplicar cosas untosas llega á perder la fuerza. La cabeza, separada del cuerpo, se siente morder á ratos; de donde se infiere que no muere del todo, ni pierde la actividad, que es lo mismo que se observa en el polipo de agua.

28 Entre los varios insectos que abundan en la Luisiana, hay mosquitos de distintas especies, cuya incomodidad es tanta, que no le excede la de los rios y climas mas calurosos y húmedos: en parte alguna se puede estar que no se experimente el ardor de las picaduras; y ademas de los comunes que llaman mosquitos, ó zancudos, y gegenes, hay los llamados frape dábor, pega de repente, damoiseles, moscones, cuya picadura es sin ardor, y hace saltar la sangre, de modo que son innumerables en especie y cantidad. Por esta razon es un mueble muy comun el mosquitero de lienzo, y generalmente usan calzon largo, que cubra toda la pierna; pero la cara y manos, que no pueden estarlo, se hinchan con el veneno que introdu- 
ducen las picaduras; siendo mas insoportable quando se viaja por los rios, que es el modo mas ordinario de transitar allí.

29 La humedad excesiva de aquel pais, los char$\cos$ y lagunillas que se forman en su planicie, y el calor del verano, que es bien grande, segun queda explicado, son suficientes motivos para que abunden los sapos. Portovelo, donde son tan comunes, no es comparable en esto con la Luisiana; los hay de diversas castas y tamaños, siendo una tan disforme, que solo el cuerpo, sin comprehenderse las piernas, tiene de diametro una tercia, ó algo mas, y extendidos casi tres quartas: el ruido de estos, en lo bronco y recio, parece al de una ternera de un año. La circunstancia de mantenerse en el agua de continuo da lugar á que las gentes los tengan por ranas; pero el color de un verde obscuro, y lo redondo del cuerpo persuade á lo contrario. Qando cantan muchos sobresalen en la voz á los de las otras especies, como haciendo los baxos; y es tal el ruido que incomoda bastante.

$3^{\circ}$ Entre los insectos abunda el ciervo volante, con cuernos largos, y varias puntas en ellos, al modo de los de venados: son peligrosos por el daño que pueden causar en los ojos, mediante que se lanzan contra la cara con mucha violencia: su color es negro, y el tamaño como el de los escarabajos grandes.

3 I. Las cucaracbas, que son comunes en la Habana, y en los otros climas cálidos, no lo son ménos en la Luisiana, con la circunstancia de ser allí de peor calidad; llámanlas ravers; son mayores que las de Cartagena ó de Cuba, de fastidioso olor, y tan perjudiciales que hacen los estragos que los ratones; porque no hay cosa que no roan y destrocen con mucha ligereza, y por esto es necesario gran cuidado para conservar papeles de importancia, ó la propia $\mathrm{P}_{2}$

ro- 
ropa: son muy sentidas y astutas, y huyen con gran ligereza al mas leve ruido.

32 Entre las especies de animalillos que hermosean la tierra en distintas regiones, debe mirarse como rara y vistosa la de los cucuyos, que abundan mas en la isla de Cuba que en las otras inmediatas. Estos son de la clase de las lucernas, que se ven volar de noche, pero muy diferentes de las comunes, y distinguiéndose de ellas en la viveza y claridad de la luz que dan, y el no ser el animal de la de gusanos con alas, á manera de mariposas. Su extructura es al modo de las curianas, ó de las cucaracbas, teniendo quatro alas, que desenvuelven de la concha ó costra que las cubre por la parte superior. En medio de la barriga tienen dos depósitos, á cada lado el suyo, por los quales despide la primer luz, siendo del grandor de dos pequeñas lentejas. Otros dos tiene en la cabeza en el lugar donde corresponden los ojos, y estos son algo menores que aquellos; así entre todos quatro hacen una luz bastante grande y luciente. El animal la descubre por intervalos á su voluntad, manteniéndola bastante tiempo, y ocultándola quando quiere. Poniéndolos en agua se alegran y vivifican; aclarándoseles la luz si están opacos ó adormecidos, basta moverlos para que la den quando por sí no lo hacen. Déxase comprehender abundar mucho en materia fosforosa; debiendo notarse, que los parages luminosos son de color baxo amarillo quando muere, ó retira la luz. En el verano, que es el tiempo én que llueve, $y$ de mayor calor, es quando se ven en abundancia, no encontrándose en el invierno. Su alimento es el xugo de la caña de azúcar, que crece y toma sazon en la misma estacion; y por esto es en los cañaverales donde se hallan con mas abundancia. No los hay en la Luisiana sin embargo de la cercanía en que está, y de cultivarse la caña, como tam- 
SEPTI MO.

poco en los parages donde esta planta prevalece. Pue. den mantenerse en xaulas pequeñas, que se hacen para el intento, quasi dos meses, dándoles de comer terrones de azúcar, cuya sustancia chupan, y es la que les convierie como extraida de la caña.

33. Siendo de noche quando este animalillo se dexa ver, y que esto sucede por causa de la luz que despide estando volando, no sería facil cogerle si propenso á la hermosura de su brillantez, no se engaTrase con las ascuas de fuego, á las quales acude luego que se le presentan, aunque vuele en larga distancia, y acercándose á ella se dexa coger. Esta propension procede de parecerle ser otro animal de su propia especie, y venirlo á buscar: así se ve que luego que ven la brasa acuden á ella quantos hay por allí, no sucediendo lo mismo con la luz de la vela. 34 En el tiempo que parecen estos cucuyos, quando la luna no alumbra, es una hermosura ver los campos poblados de tan brillantes lucernas. Las gentes se divierten en cogerlos para ponerlos en xaulas; sueltan algunos en una pieza obscura para que la llenen de claridad, siendo divertido ver gozar las luces por varias partes en todo su ámbito. Las mugeres, quando se pasean de noche buscando el fresco, suelen adornarse las cabezas, el cuello y los brazos con sartas de ellos, colocándolos de varios modos, y van resplandecientes como si llevasen coronas y collares de luces naturales.

35 En los otros paises de temperamento cálido, donde se produce la caña, y en muchos donde no la hay, no faltan lucernas; pero estas son de la especie de mariposas nocturnas, y la luz que dan no es comparable con la de los curcuyos, pues con uno de estos en la mano se lee muy bien qualquiera letra. 36 Parece que este animal se sirve de su propia luz para dirigir el vuelo, con el qual se remonta bas-

tan- 
tantemente para distinguir los cogollos de la caña, de donde se ha de alimentar. De dia está adormecido, y entónces es quando no da luz, sucediendo lo contrario en la noche.

37 Tambien es comun á la Luisiana la mucamuca, ó cbuca: llámanle rá devois, nata de bosque, y tiene las propias particularidades que las de los otros paises: así se ve ser este uno de los animales que se hallan esparcidos en las dos Américas.

$3^{8}$ Parece que los rigores de los frios $y$ hielos del invierno no debian permitir allí ciertos animales que son como naturales de los temperamentos cálidos, y de esta clase es el caimán; pero no sucede así, siendo tantos los que hay en aquellos rios, que no cedé su abundancia á la que se nota en los de la Zona Tórrida, y se encuentran de disforme tamaño: diferenciándose los de allí de los de Guayaquil, Chagres, y otros rios, en que son de un color obscuro tirando á negro, á contraposicion de otros que tienen el color de tierra parda. Danles el nombre de cocodrillos, y son dañosos para con los animales y con las personas quando se hallan hambrientos. Su tragadero es tan amplio, que tragado el cazonete de media vara de largo, y el cebo con él, lo engullen hasta su vientre, y al tiempo de llegar cerca de la orilla, tirado por la cuerda á que está asido, lo suelen vomitar, quedándose con la carnada, de lo que hay experiencias repetidas.

39 Los animales que se juzgan perjudiciales por la inclinacion que tienen á mantenerse á costa del trabajo de los hombres, no dexan de participar de alguna particularidad por donde se remunera lo que causan de perjuicio. Las hormigas son notoriamente de esta clase, por lo que disminuyen las semillas recien sembradas en la tierra para proveer sus graneros. Las plantas mas útiles $y$ bien cuidadas se aniqui- 
quilan con el estrago que hacen en ellas, royéndoles sus raices y cortezas, siendo temibles quando abundan, y particularmente las castas que hay de tamaños grandes. En las casas no son ménos perjudiciales, porque se proveen para su sustento á costa de muchos daños. Este animal, que por todas partes es destruidor y molesto en los Andes del Perú, es un grande auxilio contra las sabandijas venenosas. Es de suponer, que aunque la parte alta: de aquel dilatado pais se denomina Cordillera Real de los Andes, allá se entiende por Montañas de los Andes los paises montuosos de las vertientes orientales de la Cordillera, cuyo clima es cálido y húmedo, porque llueve mucho en él, y viene á corresponder en altura á la parte baxa occidental, llamada Valles, donde no llueve. Es abundante en culebras de las esfecies venenosas mas activas, como corales, cascavelés, las que llaman de dos cabezas, bejuquillos, y otras, en cientopies, alacranes, y de las demás clases comunes. Aquellos paises abundan tambien de una especie de hormigas grandes, que por el tamaño son fuera de lo regular, y sería inhabitable si se dirigiesen contra los racionales con el ímpetu y voracidad que lo executan contra las sabandijas. Estas hormigas, no pudiendo subsistir con el método que guardan las ordinarias, tienen otro muy particular. Son viageras por los campos, y andan á caza de sabandijas cn tropas ó compañías numerosísimas, trepando en los árboles, y buscando en la tierra el alimerto, sin dexar animal que no consuman. Del mismo modo que corren los bosques y las cañadas, se apoderan de las casas que hay esparcidas en las orillas de los rios y campos, y subiendo por las paredes no dexan rincon que no visitan, ni sabandija que no destruyan. Las culebras, de mas ponzoña y tamaño grande, los cientopies, alacranes, los sapos y lagartijas, y quan- 
to animalejo se procrea á beneficio de la humedad y del calor, no tiene resistencia para librarse de la persecucion de estos hormigones. Luego que la casa queda limpia la abandonan, y continúan su marcha buscando otros parages en donde encuentren igual pasto. Es tanto el número que carga sobre qualquier animal, que sin dexarle arbitrio para escapar, lo devoran al mismo tiempo que hace sus esfuerzos para desembarazarse de la persecucion; reconociéndose en ello, que el gran número triunfa con facilidad de la fuerza, de la ligereza, y de la activa ponzoña que hay en los que son acometidos. Llaman chaco á estos crecidos hormigueros ó exércitos de hormigones, y hacen tal ruido sobre las hojas secas de los árboles caidas en tierra, que se sienten desde alguna distancia. Con este aviso las gentes se salen de las casás dexándolas yermas, hasta que reconocen que han salido, y entónces vuelven á ocuparlas, con el beneficio de hallarlas limpias, y la seguridad de que el chaco no ha de voiver por allí hasta el ticmpo que es regular, porque sin duda sienten con algun instinto los parages en donde hay sabandijas. I a naturaleza, que se lo dió proporcionado á los animales, puso en estos la propension de alimentarse de los mas venenosos, colocándolos en aquellos territorios que son mas abundantes de ellos; y así no es de admirar que no busquen á la gente, ni á otros animales mas que á los que son incómodos y peligrosos por el veneno que encierran. La voz chaco se ha dicho ya que significa junta ó compañía; y así aquí explica compañía de hormigas, como allá de vicrineros y vicuñas.

40 No están libres aquellas partes del territorio alto del Perú, sin embargo de lo frio del clima, de las plagas que suelen padecerse en Europa. La de la langosta se experimenta algunas veces. En el año de 
62 por el mes de Diciembre la hubo en la Provincia de Angaraez, del Gobierno de Guancavelica, cuyas quebradas, que en unas es el ancho media legua, y en otras mas, se cubrieron de este insecto en tanta abundancia, que quando volaba formaba nubes espesísimas, y permanecian varios dias pasando sin cesar, de suerte que se fatigaba la vista con la perturbacion que le causaba el movimiento acelerado y continuo de ellas. Quando se sientan hacen mucho daño, particularmente si encuentran tierno el vástago de la mies: entónces se observó que el curso que hacia era contra el de las aguas de los mismos rios, y que no llegaban á las alturas, manteniéndose en la parte baxa de ellas, entre las cordilleras que las forman de una y otra parte. Esta plaga no sobreviene con freqüencia, sin embargo del poco esmero que se pone en aniquilarla: pasado el año en que sucede, median muchos sin que se reconozcan reliquias de ella. Aunque causan daño en los sembrados, no es tan considerable como el que se experimenta en Europa, y puede ser la causa la diferencia de temperamento, porque en Europa sobreviene quando los calores son mas fuertes en el verano, $y$ el temperamento de la quebrada de Iscuchaca, y de otras semejantes á ella, es como el de primavera.

4I No sería bien pasar en silencio lo que se han propagado en la isla de Cuba, por la parte de la Habana, los enjambres de abejas domésticas, en el corto tiempo desde el año 64, despues que se hizo la paz con la Inglaterra. Antes de esta época no las habia allí, pues aunque no faltaban de las otras que llaman montaraces, son distintas en especie; $y$ habiéndose transferido allá las familias que habitaban en San Agustin de la Florida, quando se evacuó, lleváron consigo algunas colmenas, que pusiéron en Guanavacoa, y en algunas estancias, por modo de 
122

ENTRETENIMIENTO

curiosidad: estas se multiplicáron de tal suerte, que se difundiéron en los montes, y se conocia que empezaban á perjudicar en las plantaciones de caña, de cuya sustancia se mantenian: su fecundidad era tal, que sin tenerlas con los resguardos que se acostumbran en Europa, daba cada colmena un enjambre al mes, y á veces dos; el uno regular y el otro pequeño, castrándose mensualmente; y en la cera y miel que se sacaba no eran ménos abundantes que acá, en donde solo se hace esta operacion una ó quando mas dos veces al año. Es tan blanca la cera, y la miel tan clara y de buen gusto como la mejor. Con estos principios, sin aplicar demasiado cuidado en su fomento, ni descuidar el cultivo de la caña como principal, podria ser el ramo de la cera y miel de aquella isla de los mas ventajosos para el comercio nacional. 


\section{ENTRETENIMIENTO VIII.}

\section{De las particularidades de los Volátiles.}

I I a parte alta del Perú no es äbundante de especies de volátiles, particularmente los de plumages hermosos y canto suave y armonioso; parece que la circunstancia de ser el clima frio es causa de no haberlos. Al contrario sucede en los climas calientes de la Zona Tórrida: la Luisiana, que par-ticipa de uno y otro en los veranos é inviernos, no tiene la variedad y hermosura que hay en la Habana, Cartagena, y demas parages semejantes; pero logra algunas especies de los de pluma bien matizada, cuyo gorgéo es divertido y agradable. El sinsonte no tiene en la pluma cosa particular, pero en la armonía del canto, y en la variedad de sus trinados, es de un embeleso singular quando se halla en libertad : su modo de cantar no es estando parado, sino revoloteando y haciendo mil juguetes con las alas en el ayre, como dexándose caer cerca de algun vástago de árbol, en el qual se apoya y levanta prontamente cosa de quatro ó seis varas: entretanto que permanece en este género de revoloteo no cesa de cantar, y muda de tonos con la misma ligereza que de positura: luego que posa enteramente entra en silencio ; y por esta razon, estando encerrado no se participa de toda su melodía. Los Franceses le llaman moqueur, burlador, porque remeda á quantos animales oye; en lo que, y en la variedad del canto é inquietud que le acompaña, manifiesta su alegría y viveza natural. Esta es causa de que en viéndose encerrado, se entristezca,

Q2 
y que muera prontamente; á lo que tambien contribuye el ser delicado para mantenerse en xaula: sin dificultad puede mirarse como el Rey de los páxaros por el canto: su alimento son los mosquitos, moscas $y$ otros insectos, y por esto tiene el pico largo y delgado, dispuesto para cogerlos.

2 Son igualmente propios de aquellos paises otras tres especies de páxaros, cuyo canto es divertido y particular: los Franceses, atendiendo á los matices de los colores, los nombran á los unos papas, á los otros caránales, y á los terceros obispos; unos y otros abundan mucho; los que llaman papas son los que en Español se nombran mariposas, aludiendo á la perfeccion de los coloridos que tienen sus plumas tornasoladis: los obispos son los que llamamos azulejos: estas dos especies son menores, que la de los cardenales, y todas tres tan delicadas para mantenerlos encerrados, que mueren muchos ántes de conseguirse alguno que resista.

3. Así como los cardenales tienen la pluma de todo el cuerpo colorada, hay otros páxaros del propio tamaño, que tienen parte amarillo el cuello, y. los encuentros de las alas negros, y son los turpianes, cuyo canto es tambien entretenido: otros que son de un color rosado hernoso, y á este modo mucha variedad; todos ellos son de paso, mediante que en el invierno no se ven por ninguna parte, y sin duda van á buscar clima mas benigno adequado á su naturaleza.

4. En las partes altas del Perú, los páxaros mas particulares son los piches, muy comunes en todas las Indias: y tienen buen canto : tambien hay gilgueros, y en las quebradas no faltan periquitos ó cotorritas de casta pequeña; y al pié de la serranía, que son las cabeceras de Valles, se ven cotorras en abundancia de la especie regular de los paises cám 
lidos; siendo reparable que en la parte llamada Valles, no las hay. Aun mas digno de notarse es, que siendo abundante la isla de Cuba y costa de Campeche de páxaros grandes de plumage, matizados de colores vivos, como guacamayos de distintas especies, y cotorras, ni estos ni los periquitos se ven en la Luisiana. La razon que puede encontrarse para ello es, que estos necesitan de temperamcnto que constantemente sea cálido, por no ser capaces de resistir los frios del invierno; y no siendo de tránsito, que con el vuclo puedan atravesar cl mar como otros, no pueden subsistir allí, donde los hielos del invierno los aniquilarian. En el territoria baxo del Perú no dexa de haber invierno, aunque el frio es moderado, procedido de mantenerse cubierto el sol por espacio de algunos meses, y de experimentarse las garuas. En las quebradas de las cábeceras que están lejos del mar, no son tan permanentes; y á correspondencia aun es mas moderado el grado de frio; resultando de ello que en alguna parte se hallan las aves de temperamento cálido, y en la otra no.

5 En las cotorras y guacamayos se observa que se ponen sobre las palmas ú otros árboles en crecido número, en cuya forma se les tira, y caen quantos puede abrazar la municion; entre cllos no dexa de haber algunos que solo estín lastimados; estos, viéndose sin facultades para volar, graznan sin cesar, y al ruido acuden los que espantados al tiro saliéron volando; y revoloteando al rededor del caido, se les tira; con cuyo arbitrio es considerable la mortandad que se hace de ellos, que es un modo cliverido para los cazadores.

6 Las aves de agua parece que se acomodan mejor á todo género de temperamentos; las especies de patos, que son distintas, se hallan con abundancia

en 
en los rios de la parte alta del Perú, y en lagunas que están sobre los cerros de mas elevacion, cuyo grado de frialdad es bastante : siendo las especies mas comunes las que llaman patos reales, que son de los mayores, labancos, patillos y gallaretas. De estas propias especies se encuentran en los /Valles; los hay en Guayaquil, en todos los paises de la Zona Tórrida, en la Habana, en la Luisiana, $\mathrm{y}$ en las partes mas al Norte de la América Seprentrional; de modo, que es entre las aves la mas difundida y abundante. Esto propio se observa en las partes mas frígidas hácia el Sur, lo qual confirma su generalidad.

7 Son muy crecidas las matanzas que se hacen de ellos en la Luisiana: diariamente se ven cazadores cargados de ellos quanto pueden soportar, siendo la carne mas ordinaria que se consume desde Novicmbre hasta Marzo; y por lo regular tienen las familias un Indio ó Mulato cazador, que saliendo por la madrugada vuelve á hora competente con porcion necesaria para el gasto del dia.

8 En las lagunas de la parte alta del Perú hay. una esfecie semejante á la gallareta, que llaman ju$j u i$ : es esta de pluma negra, y engaña con el eco de la voz, imitando en ciertas sílabas la de las personas, con tal propiedad que los cazadores se equivocan, creyendo ser los compañeros que los llaman: no levantan vuelo, y su defensa es zambullirse al sentir el rastrillo de la escopeta: esto propio sucede con los zambullidores, que tampoco lo levantan, y es otra especie diferente de la de patos: en el tamaño son como palomos; la pluma blanca, y á manera de pelo, el pico agudo, sin paletas: las gallaretas son comunes á todos temples, encontrándose con abundancia en las lagunas que son fecundas de aves.

Son 
9 Son vistosas y particulares entre las aves aquátiles las perionas por el color, siendo en el cuello, pecho y hasta la medianía del lomo de un rosado muy vivo, y tan hermoso que se viene á los ojos: desde allí va disminuyendo, y termina en blanco por la parte de la rabadilla; su cuello es largo y encorvado, al modo del de las garzas; el animal es del tamaño de las abutardas, y vuela en bandada, manteniéndose de los animalillos del agua, y de las raices de plantas que se crian en ellas: despues de muerto se apaga sensiblemente el color, perdiendo la viveza, y queda amortiguado: por esta razon es el ave en donde propiamente se distingue la vitalidad de la pluma. En la Luisiana hay, de estos páxaros y en otras partes de las Indias, como en los Cayos de la isla de Cuba por la parte del Norte: danles tambien el nombre de flamencos, y tienen un olor fuertísimo de mariscos, que los hace insoportables, bastando solo tocarlos para inficionarse. El pico es largo y grueso, adequado para cortar las raices de las eneas y juncos.

ro En los valles de la parte baxa del Perú son mas abundantes las garzas que en la alta; y en sus especies hay variedad : en la isla de Cuba los hay con mayor freqüencia; y en la Luisiana son igualmente comunes. De esta clase hay una especie, que no se encuentra en la parte alta, y sí en la baxa del Perú; la llaman espátula, porque su pico es precisamente en figura de ella; su largo es de 3 á 4 pulgadas, una ó poco ménos de ancho, y en la extremidad hace una figura circular, siendo mas ancho que el resto. Es al mismo ticmpo muy delgado, consistiendo en dos hojas finas y lisas; de suerte que no tiene diferencia á la espátula: el modo que tiene de pescar es particular, haciendo un medio círculo con la espátula tanto de un lado co- 
mo de otro; y usa de ella con tanta destreza, que no se le escapan los pescadillos quando la dirige hácia ellos: en el tamaño del cuerpo y en el color es como las garzas pardas de la casta pequeña. Es la Luisiana mas abundante de páxaros de agua que los demas paises: la casta de anzares silvestres es crecidísima; la de grullas y abutardas igualmente, y la carne de estas aún es mas gustosa que la de los patos, sin el defecto de sentir amarisco, como sucede con estos, particularmente desde Febrero en adelante, en cuyo tiempo sobresale de tal modo, que no se pueden comer sin fastidio.

I Allí son de paso estos páxaros de agua, viniendo de las grandes lagunas que están hácia la paite del Norte : en el verano no se ven, y en los dias que hace hielo es en los que son mas freqüentes las bandadas; pero si al frio acompaña alguna niebla y viento, entónces vuelan mas cerca de la ierra, y se pueden tirar mejor : de aquella costa de la Luisiana y Florida pasan á Cuba y á las otras islas, y nunca se les ve volver á buscar los paises del Norte en tiempo de calor.

I2 Otra especie de páxaros hay en la parte alta del Perú, que no entran en el agua, y andan siempre á las orillas de las lagunas: su tamaño es como el de una gallina; el color obscuro, tirando á negro, la zanca larga, y el pico largo, encorvado y delgado, parecido al de la gallineta; vuela regularmente, y su carne es buena: de esta especie no se encuentra en la parte baxa, ni los hay en la Luisiana, porque necesitan temple frio para mantenerse.

I 3 Los sarapicos y los chorlitos son de la especie de los comunes á distintos temperamentos: con igual generalidad se ven en aquellos destemples de la parte alta, como en los de la baxa del Perú; y 
en la Lulsiana no son ménos abundantes.

I4 Lo propio sucede con otra casta que llaman frayletes, yalgunos les dan el nombre de gritadores: son en algo parecidos á las aves frias. De ordinario están en la parte en donde hay humedad, siendo los enemigos de los cazadores, porque luego que los sienten se levantan gritando con un graznido agudo $y$ penetrante, que sirve de aviso á la caza; y espantada ántes de tiempo, alza el vuelo, sin dexar proporcion para tirarla.

I5 La parte alta del Perú por razon del clima fijo, y la baxa por la de no llover, son diferentes de los territoriós cálidos en donde llueve, y del de la Luisiana: en aquellos la tierra se halla desnuda, y los árboies están esparcidos, á excepcion de las quebradas, en donde el temple y accidentes varían; y estos otros se hallan tan poblados de ellos, que convidan á las aves para que vayan á anidar entre la frondosidad de sus hojas, y mantenerse con la diversidad de sus producciones. Estas circunstancias facilitan que haya en ellos las que són propias de monte. Las pavas montesas es una de las especies que allí se crian con bastante abundancia, cuyo tamaño es mayor que las de otras partes y que las domésticas : su carne es gustosa; y. es tan poco lo que se diferencian unas de otras en la figura, que se equivocan. Tienen el vuelo ligero como otras aves, siendo esto en lo que mas se distinguen de aquellas.

I6 En correspondencia de esto la parte alta del Perú logra tener perdices, y criarse alcones muy finos, con los quales se hace una de las cacerías mas gustosas y divertidas que pueden verse. Las perdices se encuentran en los Ichales, que son parages frios, $y$ no se ven en las quebradas, cuyo temperamento es mas benigno, ni se juntan en bandadas como en Europa; allí andan apareadas ó solas, y esto es causa de $\mathrm{R}$.

que 
que no sea tan fácil su caza: los paises son doblados, y lo que llaman llanadas son lomas, mas ó ménos pendientes, y baxos ó cañadas, que con la freqüencia de cuestas, y la fatiga que causa en la respiracion la sutileza del ayre, no permiten hacerla con escopeta, y por esto se usa de los alcones industriados por los Indins, de cuyo modo la perdiz que levanta el vuelo acosada por los perrillos, baxa precipitada entre las garras de aquellos que van en su seguimiento. Allí son sin comparacion mas que en el reyno de Quito. En los cerros de la parte baxa las hay tambien, sin embargo de que el clima no es con mucha diferencia de la frialdad que el de la alta. En la isla de Cuba, que es temperamento cálido, las hay asimismo, aunque en algo diferentes.

I7 Las becasinas se encuentran al simil de las antecedentes en lo destemplado de aquellas eminencias, no siendo ménos comunes en la Luisiana; suelen encontrarse tambien en la parte baxa, aunque no con abundancia.

I8 Los condores, cuyas singularidades merecen no pasarse en silencio, son sin duda de las aves que vuelan la mayor que se conoce, sirviéndonos de esta frase para distinguirla de los avestruces, que aunque se sirven de sus pequeñas alas, no son suficientes para el vuclo. Estos otros, por el contrario, son de los que mas se remontan en aquella atmósfera, cuya densidad desde luego se puede asegurar sin error ser la mitad de la que tiene en el nivel del mar. El es tan propio de los climas frios como de los calientes, encontrándose en lo alto de las Punas del mismo modo que en los Valles; pero no los hay en las partes que están pobladas de árboles, ó son montuosas como Guaraquil, Panamá y otras: su pluma forma un entretexido tan bien preparado, que no lo penetra la bala de fusil, ni el animal se inmuta al recibir el gol- 
pe. Ha sucedido tirarle 8 ó Io tíros seguidos, oyendo dar las balas sobre él, y caer estas al suelo de rechazo sin haberle hecho daño alguno: por varias veces repetida esta experiencia en la parte alta del Perú, no hubo exemplar de poderlés penetrar con tiros regulares. Debe süpónerse que lo que sucede allí puede no ser regla para otras partes, porque con el frio del temperamento están los poros mas cerrados, la piel es ménos flexible para dexarse penetrar, y á su semejanza la pluma, con particularidad en una ave que está tan vestida de ella. En las playas del mar del Sur, que desde los quatro grados por aquella parte empiezan los Valles, hay mucha abundancia de ellos, saciando su voracidad en el pescado muerto que arroja el mar, y se tiene por peligroso pasar por donde están, pues siendo animal de tanta fuerza darán fin de quien lo intentase.

I9 Ia variacion que tienen las cosas en el mundo se toca á cada paso; y lo que un dia se registra de un modo, con el discurso del tiempo se halla diverso otro. El rio de Chagres es muy diferente al presente de lo que era 20 años há : la frondosidad de sus orillas, la abundancia de animales propios de aquel temperamento, la hermosura en los matizes de las distintas especies de aves que se registraban entre los pimpollos de los árboles, y alternaban en sus cantos, y el conjunto de un verdor muy vivo $y$ variado, se ha transformado en casas de madera, fabricadas á distancia unas de otras por las gentes que se han establecido allí, las quales, desmontando desde las orillas hasta cierta distancia en lo interior, han dado cultura en la tierra, desterrando por este medio la abundancia de aves $y$ animales que poblaban ántes aquel rio.

20 A vista de este exemplar no es dudable que con el curso de los tiempos las cosas de aquellos reynos muden de aspecto tomando otro diverso, y acer$\mathrm{R}_{2}$ cán- 
cándose al que tiene Europa. En estas novedades se conservan las razas de animales y de las aves sin alteracion, con solo la diferencia de que unas se retiran de los parages donde no encuentran las proporciones que necesitan para hacer sus nidos y alimentarse; $y$ : las otras se minoran sensiblemente, como sucede con las vicuñas, á fuerza de perseguirlas y de hacer crecidas matanzas en ellas.

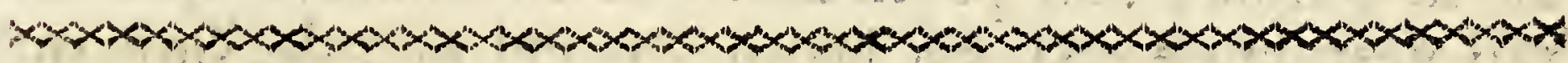

\section{ENTRETENIMIENTO IX.}

\section{Sobre los Pescados particulares.}

I 1 o es ménos abundante el elemento del agua en los pescados, que los de la tierra y el ayre en los animales y volátiles. Estos se mantienen de los alimentos que les da la misma tierra, y á medida que varían por causa del temperamento, ó por la de la sutileza del ayre, es ménos extraño que se diversifiquen entre sí; y que los que se hallan en una region no sean comunes á otras. En el agua y en sus producciones parece que no deberia ser tan sensible la variedad, por no constar de la combinacion de partes que constituyen aquella; no obstante se observa que las producciones de animales aquátiles no son unas mismas; y que las especies que hay en unos mares no son comuncs á otros, si bien hay algunas que lo son. De esto debe inferirse que ademas del temperamento, y de los pastos de que se alimentan, concurre la generalidad de las semillas, ó su falta. El mar del Sur es abundante de pescados: la parte alta en sus rios y lagunas no lo es tanto en el Perú, y ménos en la de Quito; sin que esto pueda atribuirse á ser mas templa- 
pladas las aguas en unos que en otros, ni á la circunstancia de llevar mas rapidez, porque en esto son iguales. Pero ántes de explicarlo será bien decir algunas particularidades de aquellos mares.

2 Las ballenas son bastantemente comunes en el del Sur, no solo en la bahía de la Concepcion, y de allí hácia mayor altura, sino en los parages dentro de los Trópicos, y hasta los I 2 ó I 3 grados de latitud. En Europa es regular irlas á buscar los que se ocupan en su pesca á los climas frios del Norte, siendo raro verlas de los 40 grados hácia ménos latitud. La causa de esta diferencia no es fácil averiguarla, porque si fuese por razon de ir á los mares en donde no hay. sardina, las costas de Galicia son abundantísimas de ella, y no por esto se ven con freqüencia, como sucede en el mar del Sur. Lo que allá se repara es que acuden á la anchoba ó anchobeta, cuyo pescado es abundantísimo, y que con este incentivo se ven en cantidad, y algunas quedan baradas en las playas por ir en su seguimiento, y allí mueren despues de mucha brega.

3 No es fácil decir si las que allí freqüentan las costas de poca altura son con toda precision del mismo tamaño que las de los mares de Europa; pero 10 que no admite duda es que son parecidas en la figura, $y$ disformes en el grandor, pues las hay tales, que puestas al costado de una embarcacion de 700 toneladas, cogen tanto espacio como las tres quartas partes de su largo, considerándolas desde el principio de la cabeza hasta la extremidad de la cola; de suerte que pueden regularse á corta diferencia de 25 varas de largo; y como entre ellas hay mayores y menores, no puede ser este tamaño regla fixa para todas las de aquel mar. Sus cabezas, como si fueran peñascos donde batiese el mar, se hallan llenas por la parte superior de escaramujos y de conchas de varias especies, que 
que se pegan y hacen allí su procreacion, no ménos que de verdin, al modo del que se cria en las mismas peñas, ó en las partes de los navios que baña el agua despues de mucho tiempo de no haberse limpiado.

4 Este pescado monstruoso se sustenta de la anchoba, y el módo de proveerse es digno de notarse. Se acerca á los parages en donde hay cardumen, esto es, que se halla en gran porcion por ser comederos; y allí, azotando el agua con la cola muchas veces, y batiéndola á fuertes golpes, mata quanta puede alcanzar, que por ser grande y muy abierta tiene bastante extension; y así continúa hasta que el cardumen se divide huyendo de la persecucion; entónces come là que queda muerta, y vuelve despues en busca de aquel para darle nueva embestida. Sucede en los pescados lo que entre los animales terrestres, que unos andan separados, y otros en compañía: la sardina $y_{\text {! }}$ anchoba son de la clase de estos segundos; y los parages en donde tienen comederos están tan poblados de ellas que no se ve otra cosa : de aquí viene que las matanzas que hace en la muchedumbre son correspondientes á lo que nécesita para manténerse.

5 Es perseguida la ballena de otros pescados que tiene por enemigos, pero principalmente del pexe espada y pexe sierra: su defensa es con la cola, como que siendo de un tamaño disforme es la mejor arma de que se puede servir. El combate de uno con otro es divertido por las vueltas y movimientos extraordinarios que hace con ella y con la cábèza : unas veces saca fuera del agua la una, que parece salir un promontorio; otras la otra, como si fuese vela de embarcacion, en donde reverbera el sol como si diese en un espejo, y dexándola caer rabiosamente sobre el contrario, azota el agua fuertemente levantándola en gruesos borbollones. Entónces se le percibe estar enfurecida, y lo denota no solo en la forma de mover- 
se y manejarse, sino tambien en los mugidos roncos: que despide, siendo tales que se perciben á la distancia de uná legua de la playa. Es cosa sabida ser este pescado de la clase de los que arrojan por las trompas. ó aberturas que tienen sobre la cabeza el agua que recibe por los conductos de las quixadas y agallas. Esto. lo hacen al tiempo de sobrenadar en el agua, y la que levantan en penachos muy altos es en bastante porcion. Quando descubren la cabeza por estarse combatiendo, no son tan altos ni tan abundantes los penachos, siendo la causa la agitacion que padece; pero quando no milita este empeño ni el de la pesca, parece que se recrea, porque con tranquilidad descubre la cabeza señoreándose en las aguas, y con el bufido ó soplo despide los promontorios de ellas, que divididos en el ayre hacen una vista hermosa, á lo qual ayuda el reflexo del sol que da en ellos.

6 Así como tiene combates con sus contrarios, y persigue á los que neccsita para alimento, se exercita otras veces en retozos con sus semejantes: entónces se aproximan sacando la cabeza fuera del agua á un tiempo, se ponen muy cerca la una de la otra, y haciendo demostracion de quererse asir con la boca, se desembarazan como burlándose la que huye de la que acomete: otras veces se enroscan por las colas, y entre estos movimientos sacan del agua mucha parte del. cuerpo con ligereza, como haciendo amago de saltar. Todos estos exercicios son por lo regular dilatados: en el combate suele mantenerse una mañana entera: en el retozo ó juego con las de su especie lo mismo; y en la pesca permanece quanto le dura el hambre, ó halla cardumen en donde cebarse. Los dias serenos, quando el sol está mas vivo, son por lo comun en los que da señales de retozo: en los turbulentos y opacos es regular no parecer; y al nadar sobre las aguas para arrojarlas saca la cola, despues de zambullir la 
cabeza, haciendo tantos remolinos como los que for ma un navio por su popa.

7 Tiene espiracion, que es con la que despide el agua : en ella suele arrojar eructos de tanta fetidez, que inficionan el ayre en dilatado espacio, siendo tan fastidiosos é insoportables, que no se pueden resistir quando los repite mucho: este es efecto de la porcion de escrementos ó materias indigestás que encierra en su estómago.

8 En Europa se van á buscar á las partes frígidas del Norte, armándose embarcaciones expresamente para ello, y esto se hace con el fin de convertirlas en aceyte, y de aprovechar sus agallas, que es lo que comunmente se llama barba de ballena. En las costas de la Nueva Inglaterra se hacen tambien pesquerías con bastante estipendio; y de lo que llaman esperma se $f_{a-}$ brican las velas que tienen este nombre, siendo de tanta ó mas duracion que las de cera, con la ventaja de ser mas blancas, transparentes, no correrse, ni dar olor alguno: hacen la luz muy clara, y nada pesada para la cabeza. De lo que se saca de este pescado se proporcionan distintas cosas para el uso de la vida y del comercio. En el mar del Sur, donde sin trabajo y sin armamentos ni gastos pudieran hacerse pescas crecidas, aun dentro de las mismas bahías, y sin apartarse de las costas, no se ha pensado en ello; y se desprecian las utilidades que facilitarian, no solamente á aquel reyno, sino á la España, por las crecidas cantidades que se gastan en barba y cera del Norte para alumbrarse y para el consumo de ambas Indias. En estas se hace poco aprecio de lo que no es plata ú oro, siendo esta la causa del abandono en que seadvierten esta.y otras especies de comercio, sin consideracion á que la plata se desaparece como los vapores de la tierra quando faltan las otras cosas necesarias para la vida, $y$ que sin tener los medios de 
conservarla, es un engaño de la aprehension. Allí podrian hacerse grandes pesquerias sin mas trabajo que ir sobre ellas por las costas en lanchas con los atavíos necesarios. El aceyte tendria el propio uso que se hace de él en las demas partes; y las agallas, osamentas y grasa producirian muchos quintales de esperma, así como en la Nueva Inglaterra, donde son estas cosas parte de las minas que les proporcionan las riquezas que atraen con ellas.

9 De los pescados que abundan mas en aquel mar es uno el que llaman chita: su calidad es delicada, y se conduce fresco sin sal para el consumo de la parte alta. Su tamaño es como de media vara; y tiene de ancho cosa de una tercia, haciendo figura quasi oval: su carne es en hojas, y estas muy blancas al modo de la corbina; y el mucho gasto que hay de él, así fresco como salado, acredita su abundancia; la que tambien se verifica de otras especies que son comunes.

ro De los pescados de rios, los de la parte alta por lo comun se reducen á dos clases, que son preriadillas y bagres; y solo se distinguen en que las primeras son pequeñas, no excediendo de pulgada y media ó dos; y los segundos los hay hasta de mas de tercia : unos y otros son de cabeza chata y redonda, de pellejo que tira á obscuro, y sin escama, sobre el qual hay una baba pegajosa, que para comerlos es necesario quitarla estregándolos mucho con ceniza, porque de lo contrario les comunica olor y gusto fastidioso. La carne es blanca, delicada y sabrosa, y no tienen mas espinas que la de en medio. En los rios que corren por aquellas quebradas es en donde los hay, pero no con mucha abundancia. En el reyno de Quito, aunque en algunos de sus rios se crian preñadillas, los mas de ellos no tienen bagres, siendo así que ni en temperamento ni rapidez tienen desigualdad. Solo hácia la parte de Cuenca se encuentran de ellos, cu$S$ 
yo temperamento es desde I 3 hasta 15 grados de calor constantemente todo el año: dos grados mas que el de Iscuchaca en invierno, y uno mas fresco que el mismo en verano; pero sin llegar á aquel parage hay cerca de la ciudad de Quito muchas quebradas, en cuyos terrenos se cria la caña de azúcar, que requiere clima mas cálido que el de Cuenca, y sin embargo de ello no los crian; de lo que se debe inferir, que el no haberlos es por faltarles la especie. Tienen tambien los rios de las quebradas de la parte alta del Perú un anfibio que llaman zaramagullon: este es todo negro, el cuello largo, y el pico al modo del de los patos, pero mas estrecho: su tamaño es como el regular de aquellos, y la pluma tan pequeña, que es un medio entre pluma y pelo: en su carne sobresale mucho el gusto de marisco, de que se infiere que se mantiene con las preñadillas ó con los bagrecillos chicos.

I En los lagos situados en partes frígidas, superiores al terreno en que están las poblaciones, no se encuentra especie alguna de pescados, dexándose entender no ser adaptado el clima para ellos por causa de la mucha frialdad.

I 2 Parece que los pescados mas grandes deberian tener mayor resistencia al frio que los pequeños; $y$ que aquel clima en donde empieza á haber proporcion para la subsistencia de estos vivientes habia de verificarse en aquellos que son de mas corpulencia, con respecto á la cantidad de agua que llevan los rios, para que pudiesen nadar; pero no sucede así, siendo muy al contrario, que los mas pequeños son los que se crian en ellos. En aquellos, cuyo clima es mas frio que el de las quebradas, como de 5 á 6 grados sobre la congelacion, se crian unos pescaditos tan chicos, que aun no llegan al tamaño de media línea; llámanles chicbes: son de la hechura de un besuguito, y abun- 
abundan tanto que no tienen número; nadan por la superficie del agua, y. los Indios los pescan con unos cedacitos ó esterillas de junco, metiéndolas en el agua como para espumarla: hacen de ellos unas tablillas de media quarta de largo y quatro dedos de ancho con medio de grueso, poniéndolos en prensa para que se unan unos con otros, y despues los preparan al humo: sirven así para condimentar las comidas, á las quales comunican un ligero gusto de marisco, que se acomoda al paladar de aquellas gentes agradableniente. En Lima, como en todo el Perú, se hace considerable consumo de ellos, entrando en el número de las especerías. No se encuentran en todos los rios, siendo señalados en los que los hay, y se cogen en donde hacen remanso. Nunca llegan á crecer mas de aquel tamaño; y los hay tambien en temperamentos algo cálidos. La circunstancia de estar en la superficie del agua da á entender que viven de los insectos imperceptibles del ayre que se mantienen de la misma agua.

I 3 Los antiguos Indios usaban del chiche para aderezar sus comidas, y de ellos lo aprendiéron los Españoles; siendo la esterilla en su hechura y el modo de usarla semejante á lo que acostumbraban para otros fines; y ellos son los que se ocupan en este género de pesca, que pide bastante paciencia, habiéndose de mantener en el agua hasta la rodilla, en cuya forma van andando lo largo del rio, y espumando el agua, como queda dicho, para sacarlos. Quando están vivos se les nota algun movimiento, pero sin saltar mucho, tal vez porque su pequeñez no se lo permite.

I4 No se reconocen en aquellos rios otras especies de pescados mas que estos, y es natural que sea por no haber en ellos la semilla correspondiente, pues así como los que se han nombrado subsisten, pudiera 
haber otros que en rios de climas frígidos y de bastante corriente no faltan.

I5 Dexando los paises Australes, se pasará á dar noticia de algunas particularidades en los de la parte del Norte de la Equinocial: y empezando por la $\mathrm{Ha}-$ bana, será lo primero la infeccion de la ciguatera; esta es una enfermedad, que comunica el pescado quando se halla maleficiado de ella, y con particularidad cierta especie que dicen ser mas propensa á él que las otras : basta comer una vez de él para contraer el mal. Esto se atribuye á que come la fruta que llaman manzanilla, la qual es de las que crian aquellos campos, y se tiene por venenosa, á lo qual corresponden los efectos que causa; por esta razon está prohibida la venta de los que llaman ciguatos, y dicen que se conoce en que tiene los dientes amarillos; y poniéndole en la boca quando está cociendo algo de plata, toma el color de cobre. Los efectos de este mal consisten en laxitud de todo el cuerpo, ponerse el color pálido, el semblante abatido y macilento, la vista triste, dolores fuertes en las coyunturas y huesos por todo el cuerpo, y enflaquecerse sensiblemente, acompañándolo la inapetencia á comer y disgusto á todo. Si no se procurase atajar el progreso, terminaria fatalmente. El remedio que comunmente practican es usar del aguardiente bebido, y de algunos apósitos que aplican para mitigar los dolores: la parte espiritosa de este licor anima los espíritus, pone en movimiento la sangre para que se sacuda del humor maligno que la inficiona, y se restablece la naturale$\mathrm{za}$, pero no sin que se tarde algunos dias y aun meses en ello.

I6 Esta qualidad nociva de los pescados no se conoce en las costas de Cartagena, Tierra-Firme, ni c n las otras de aquella parte, sin embargo de haber por allí el árbol del manzanillo con abundancia, y 
NONO.

de tenerse su fruta lo mismo que en la Habana por venencsa, y reputarse hasta su sombra por dañosa; siendo digno de notar, que en los pescados afectos á este vicio no queden señas del veneno en la carne, ni se adviertan á la vista desmedrados y enfermos.

I7 La tortuga es muy comun en aquella isla, $y$. se vende su carne del mismo modo que la vaca: la pesca grande de estas se hace en la parte occidental en los parages baxos de Santa Isabel, y en otros de ella donde el mar tiene poco fondo : para ello se echan al agua los pescadores, y siguiéndolas se abrazan con la que encuentran, y la trastornan, poniéndolas boca arriba, cuya diligencia les quita la facultad de nadar. De este modo las colocan en las embarcaciones para llevarlas á la Habana, y allí las ponen en corrales de estacadas que tienen hechos dentro del agua, para que se conserven vivas, hasta que llega el tiempo de matarlas para venderlas. La carne es blanca como la de la gallina, pero de mas consistencia. En la estacion del estío busca este animal las playas de arena para poner sus huevos en ella, y el instinto les hace elegir los parages donde peligren ménos con los pescadores que las persiguen : las islas de los Caimanes son de las que mas se pueblan; y luego que sacan las crias se vuelven con ellas á los antiguos comederos.

I 8 Tambien abundan aquellas costas de careis; $y$ aunque estos son parecidos á aquellos, por ser una de las especies de ellas, hay mucha diferencia en la carne, siendo nociva para la salud, quando la otra no lo es: las costas y demas islas de aquel mar, particuJarmente las que están entre la Equinocial y el Trópico de Cáncer, son abundantes de las primeras; pero ficra de las inmediaciones de la Habana no son : frequentes los careyes. En el mar del Sur no son tan generales las tortugas; y en la Luisiana son bien raras; 
pero en los rios que entran en el Misisipi las hay, cuyo grandor es hasta de media vara ; siendo muy pequeñas respecto del tamaño que tienen las del mar, y particularmente desde la Habana hácia Cartagena y. Tierra-Firme.

I9 El rio Misisipi, sin embargo de ser uno de los grandes de la América, y de tener la profundidad que se ha dicho ántes, es pobre de pescados, y entre las pocas especies que tiene, el que mas abunda es despreciable. Este es uno que llaman barbudo, de la figura del bagre; los hay muy grandes, y tienen alguna semejanza en el vientre á los taburones. La carne es muy floxa, flemosa y de un gusto insípido; por esto solo la come la gente pobre y los negros. Los lagos que por la parte del Norte forman la isla en que está el Nuevo Orleans, y son formados de la entrada que hace el mar entre la costa firme de la Movila y la isla, tienen abundancia de pescados, siendo de estos de los que se abastece la ciudad. Las aguas del rio son frias en todo tiempo, cuya circunstancia puede ser causa de la escasez que tienen de pescados en especies y en cantidad.

20 No sucede así con los camarones y con los langostinos, de los quales parece estar sembradas las tierras con sus semillas, segun la abundancia y facilidad con que se procrean, multiplicándose sin término. Cada especie de estas tiene su tiempo; y es tanto lo que hay de ellos, que vulgarmente dicen allí ser el maná del pais, porque en realidad se suple la necesidad de aquellas gentes, sirviéndoles en parte de alimento y de gusto. Con las lluvias en tiempo de verano, que son copiosas, se llerian de agua los parages desiguales y los hoyos de donde se ha sacado alguna tierra, y luego se encuentran en ellos los langostinos en bastante número; pero consumida el agua, porque dexa de llover, vuelve á quedar el parage se-

co, 
co, sin indicios de haber en ellos tales animales. La causa de esto parece no ser otra que comunicarse las semillas con las mismas aguas del rio, quando estas en las crecientes rebosan por las orillas, ó por medio de los caños ó cequiones que abren para los molinos; $y$, esparcidas por la tierra se recogen en las lagunillas, y procrean en ellas con brevedad: allí es regular ir por la tarde á pescar los langostinos que han de servir de cena : cada familia envia algun muchacho de sus esclavos, y estos hacen la provision que se necesita, sin que se reconozca ménos abundancia en todo el tiempo que es regular haberlos; pasado este no. vuelven á verse hasta el año siguiente.

2 I Quando concluye el tiempo de los langostinos empieza el de los camarones; no siendo ménos abundantes que aquellos: y aunque hay de estas especies en otras muchas Provincias y en los rios del Perú, no son freqüentes como en la Luisiana.

22 De los otros pescados que son ordinarios en los mares y costas, hay abundancia; pero la isla de Cuba lo es en conchas y arborizaciones marinas, de las quales hay variedad de especies, cuya descripcion y noticia pedia un tratado particular. 


\section{4}

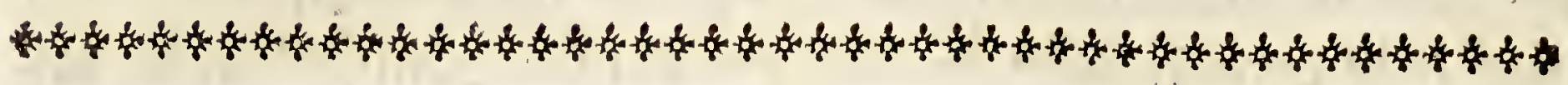

\section{ENTRETENIMIENTO $\mathrm{X}$.}

De los lagos y de los rios, dando noticia de lo que contienen de particular.

I I os paises mas abundantes de rios en terrenos desiguales y escabrosos, parece que deben serlo tambien de lagunas: porque de estas salen aquellos, y se forman, recogiéndose el agua en los valles ó llanuras algo profundas, hasta que rebosando por la parte que está ménos alta $a_{1}$, se desahoga por ella, distribuyéndose en uno ó mas rios, segun la division que despues hace, ó los distintos surtideros por donde se derrama, sin que esto obste á que las haya en los llanos donde concurra la misma razon, y aunque no en tanto número son regularmente de mayor extension.

2 En el Canadá, por la parte que corresponde al Sur y al Occidente, entre ella y la Luisiana, hay varios lagos, y algunos de 60 á 80 leguas de largo, con el correspondiente ancho, siendo así que el pais es llano y baxo; pero esta misma circunstancia contribuye á ello, porque las aguas que se recogen en su anchuroso espacio, encontrando terrenos baxos é inferiores al resto de la llanura por donde corren, los llenan hasta ponerlos iguales con la que sigue, por donde se les franquea el paso hasta el mar.

3 De este modo se forma el rio de San Lorenzo, ministrándole el caudal de aguas el lago Hontario. Este las recibe del Erie, á quien las comunica el Huron, y á este las da el Superior, que está de los $4^{6}$ grados hácia el Norte, ocupando entre todos de Oriente á Occidente como 400 leguas. 
4 No solo recibé cada uno de estos lagos el agua del inmediato que le precede, sino tambien de muchos arroyos y rios que van á dar á ellos: por esto vienen á hacerse mares en medio de la tierra, de. biendo reputarse por tales quando son de tanta extension. Lo mismo sucede en Europa, y en las otras partes del mundo. Las desigualdades de la parte alta de la América Meridional, siendo correspondientes á la freqüencia é inmediacion que tienen las montañas elevadas, no pueden dexar parages llanos de tanta magnitud como aquellas.

5 Dáseles tambien el nombre de lagos, aunque impropiamente, á algunas ensenadas que forma el mar entre dos tierras, introduciéndose ó teniendo su comunicacion por alguna boca estrecha. De esta clase son los lagos Borgne, Pontchartrain y Maurepas, que por la parte del Sur se hallan contenidos con la isla del Nuevo Orleans. A estos, si no se les quisiese aplicar el nombre de babia por su poco fondo, pudiera dárseles el de balsas ó ensenadas del mar, para distinguirlos de los otros.

6 Hay otra suerte de lagunas que forman los rios quando su caudal es corto en las orillas del mar, pues al modo que los grandes forman barra, los pequeños, no teniendo fuerza para romper el impedimento que las olas les oponen, se rebalsan, franqueándose paso unas veces por entre las concavidades y poros de las piedrecillas y arenas que los contienen, y otras rebosando por encima á donde el impulso de aquella no alcanza. De lo que queda dicho se ve que los lagos deben entenderse de tres modos: en el uno los grandes de una extension de muchas leguas como mares, otros pequeños; y otros los de las orillas del mar. Que los primeros están en las llanadas de mucha exrension: los segundos en los paises altos de serranía escabrosa; y los terceros en donT.

de 
de los rios van á dar al mar.

7 En los territorios baxos y llanos los arroyos y pequeños rios, juntándose en un solo parage, si encuentran proporcion para ello, forman lo primero una laguna: el desagüie de esta es un rio, que despues engruesa con las que se le juntan en el tránsito hasta el mar. En los paises montañosos se recogen las aguas del circuito de las montañas en el valle que forman entre sí, como si cayesen en la concavidad de un estanque: de su desagüe se forma algun rio, y tiene principio la quebrada por donde corre: aquel y esta son en el orígen pequeños, pero el primero se va engrosando, y la segunda va tomando profundidad de tal modo, que á la distancia de dos ó tres leguas forman cauce; la profundidad y las eminencias, que le sirven de caxa, son montañas de bastante altura, en cuya proporcion quanto mas se apartan del orígen son mayores. De este modo viene á conocerse el nacimiento de aquellas grandes quebradas ó aberturas, que por sus cabeceras no son de consideracion, y despues aumentan de profundidad y anchura.

8 La parte alta del Perú se halla por todos lados dividida en quebradas, por las quales corren otros tantos arroyos, que por lo comun tienen su principio en los lagos, como se ha dicho: así no es extraño que sean alli mas freqüentes que en otras partes, y que se encuentren á cortas distancias unos de otros, como de dos ó tres leguas; pero por lo regular sú extension no llega á un quarto de legua en lo largo. Crecen en sus orillas ó en las islas que forman algunos carrizales, eneas y juncos: lo mas ordinario es hallarse en las partes superiores á las poblaciones, y muchos de ellos en donde no consiente el clima, por lo frio, que crezca el icho ó pajón.

9. Estos rios, que baxando de la cordillera siguen 
su curso por el pais llano, padecen diminucion de sus aguas, por las que se emplean con necesidad en fertilizar las tierras que no participan del riego del cielo, y no llevando fuerza suficiente para entrar en el mar quedan detenidas las aguas, esparciéndose con el rebalso que hacen; para lo qual contribuye tambien la circunstancia de ser muy llano el territorio, y sin declive. Estas lagunas desaguan filtrándose, segun se dixo, por entre las mismas piedras, ó rebosando por el bordo que las detiene.

ro Por lo general los rios de la parte occidental del Perú, que van al mar del Sur, no son tan caudalosos como los de la oriental, que salen por las costas del mismo lado, porque el mayor espacio que corren estos últimos les facilita el ingreso de mas aguas que los van engrosando.

I En las lagunas donde es excesiva la frialdad del clima, y que esta comunica esterilidad á la tierra, no se ven animales; y los volátiles, á excepcion de los que son propios de agua, se ven muy raros; pero hay otras en que aburdan, con tanto exceso, que las aguas están cubiertas de ellas, y por lo ordinario son estas las que están en parages mas descampados, por hallarse los cerros mas distantes entre sí, y por lo regular situadas en los lugares mas altos, ó en otros que no están inmediatos a las Punas mas eminentes, donde nunca se desaparece la nieve: de lo que puede inferirse que estos animales buscan lo mas desembarazado, sin que les perjudique lo mas frìo.

I2 Del mismo principio que tienen allí los arroyos y rios nace la abundancia de los manantiales que se ven: los receptáculos de agua dexan filtrar mucha de ella por las porosidades de la tierra: hallándose en elevacion corre por los conductos subterráneos hasta que se abre salida por donde encuen$\mathrm{T} 2$ 
tra ménos resistencia. Por esta razon son tan comunes, que se encuentran ojos de agua á cada paso, y algunos de ellos tan considerables, que desde su principio forman arroyos: estos corren á juntarse con el rio mas cercano, y la concurrencia de muchos lo engruesan; asi, aunque la parte que rebosa de las lagunas no sea considerable, desde luego que sale de ella va aumentándose con la que le tributan los innumerables surtideros ú ojos que va encontrando en el camino; unos dimanados de la propia laguna, otros de diversas, y todos siguer por donde corre el principal brazo. De aquí resulta que aquel territorio esté dividido en ramificaciones de arroyos y rios por todas las partes que se mira, cuya pintura da idea de las aguas subterráneas, pues siendo tantos los surtideros, es correspondiente el número de veneros ó arroyos ocultos que la penetran.

I3 En los territorios baxos y llanos corren los rios á su centro naturalmente con curso lento, y. nada estrepitoso: las vueltas y tornos que forman dilatan su camino, y esto ayuda á fecundizar mas parte de tierra; supliendo así en el Perú la falta que le hacen las lluvias, las fuentes y arroyos, pues en ellos es preciso andar algunas leguas para encontrarlos.

I4 Por lo comun son las aguas del pais alto delgadas, cristalinas, y muy puras: naturalmente siempre están frias, conservando esta qualidad del clima de donde provienen; pero es bastante regular incorporárseles otras de ciertos veneros, que las vician: all? Ilaman á estas colpales, siendo propiamente vitriólicas: esta qualidad la toman de los minerales por donde pasan; de ello se origina, que tanto quanto son saludables ántes de la union, son nocivas despues de ella; y no solo se distinguen en el gusto, sino en el color, que comuican á las peñas que bañan, y á 
las orillas, poniéndolas roxas anaranjadas, procedido de la costra que van formando en ellas. La abundancia que hay de este género de aguas indica ser bastante comun el vitriolo y los betunes en aquellas tierras: por esto varios rios grandes, que en el origen tienen aguas buenas, despues de haberse engrosado son malas y de, gusto salobre; pero estos mismos, juntándose ántes de salir al pais baxo con otros de igual ó mayor caudal, que no parricipan de tal defecto, vuelven á mejorar perdiendo la malignidad. Tambien concurre á disminuirla el sedimento que dexa por donde pasa, no ménos que aquella costra que forma en la peñasquería que va lavando: por esto en la parte del territorio baxo, que corre desde que entran en él, no se percibe el mal gusto, $\mathrm{y}$ son útiles para el regadio y para beberse.

I) Hay ciertas aguas con la propiedad de petrificar las cosas que caen en ellas, como las hojas de los árboles, las maderas, los huesos, ú otras, especialmente si abundan en porosidades: la causa de ello es que contienen mucha parte de limo sutil, y algun ácido mineral, que al paso que se para aquel, se une y endurece, fixándose en los remansos, ó en el mismo suelo del cauce; pero es particular que la misma agua pierda la fluidez, siendo una de las qualidades esenciales de ella, y que se fixe, formando canteras como las de qualquiera otra piedra. Es comun el concepto de decirse que la villa de Guan. cavelica está fabricada con piedra de agua; y que allí la de ciertos manantiales que están inmediatos se convierte en piedra, que despues cortada y labrada se emplea en los edificios. Si lo antecedente es tan extraño, no deberá serlo ménos la circunstancia de que esta agua, de que se forma la piedra, es tan cristalina, transparente y pura, que parece no contener cuerpo extraño. Aquella villa está rodeada de es. 
estos manantiales, y en cada uno de ellos hay canteras de la misma piedra: el agua es caliente en tanto grado, que de continuo humea, pero particularmente al salir de la tierra, de tal modo, que aunque no llega al grado de herbir, no se puede tener la mano mucho tiempo en ella. Reposada en un grande estanque cortado en la misma piedra, que está inmediato á uno de estos mismos ojos ó manantiales, no se reconoce que haga incrustacion en los costados, ni que por el suelo deponga la materia, que petrificada disminuya la profundidad. En el se crian aquellas yerbas que son regulares en donde está el agua retenida. Los derrames del estanque, bañando la tierra por donde corren, sin haber perdido del todo el calor, hacen en quanto humedecen una costra delgada, que tira á color amarillo, y esta con el transcurso del tiempo va engrosando y tomando cada vez mas cuerpo: en los principios no es dura, pero á medida que va quedando mas profunda adquiere mas consistencia. Las yerbas que no están arraigadas, las astillas ó ramas que se quedan paradas en algun remanso, se petrifican igualmente, y se encuentran incorporadas con las mismas costras. Esta piedra es ligera, aunque no tanto como el agua, porosa y blanda para cortas, cuyas qualidades conserva aun despues de haber pasado tiempo de estar al ayre. La hay de dos especies, una cenicienta clara, y otra naranjada: la primera es de mas consistencia que la segunda, siendo diversas las canteras; de lo qual debe colegirse, que segun la especie de la tierra que baña el agua, así resulta la piedra distinta en el color y solidez.

I 6 El gusto del agua es malo, por ser gruesa y salobre, pero los efectos son peores; y por esto los animales no la beben aunque estén precisados de la sed. En el olor no se le percibe cosa extraña, y usan de 
de ellas para baños, sin que se haya reparado haber ocasionado malos efectos.

I7 Inmediato á Guancavelica, y por su frente, hay un cerro de regular alcura, que llaman Potoccbe: del pié de este, á corta distancia, salen varios ojos de agua; los unos las dan en extremo saludables y delicadas, y los otros nocivas en el mayor grado: las primeras salen en el grado de frialdad que es regular en aquel temperamento; las otras con humareda tan abundante y densa, particularmente en la estacion de los hielos, que forma nube sobre ella: de las unas á las otras habrá medio quarto de legua, y en esta corta distancia se encuentra repetida esta gran diferencia. Las calientes son las que, como va explicado, forman la piedra; de lo que se dexa inferir, que aunque se hallan tan cercanos entre sí los surtideros por lo interior de la montaña, siguen distintos conductos, que no se comunican; siendo muy particular que alternándose unos ojos con otros, y. siendo varios los que hay de cada especie, no se crucen por adentro, ni salgan sus aguas mezcladas.

I 8 Estas aguas calientes petrificantes son muy regulares en la parte alta del Perú, encontrándose en muchos parages, pero en ninguno son tan abundantes como en aquel territorio de Guancavelica. Sobre la formacion de la piedra se ofrece un reparo, y es, que los parages que baña donde se reconocen las incrustaciones, no se ve que con el transcurso de los tiempos hayan crecido sensiblemente en altura mas que las tierras contiguas, hallándose iguales con ellas: y las canteras de donde se saca la piedra están desde aquella superficie profundando hácia abaxo; de modo que se hacen hoyos muy profundos en donde se abre cantera, lo mismo que sucede con las de otras especies : esto da lugar á creer, no que el agua, como cree la vulgaridad, se convierta en piedra por un 
modo de coagulacion, sino que tiene la propiedad de unir las partes de la tierra, y darles la dureza que se ve en la piedra: de no ser esto, era preciso que el estanque que se ha dicho, despues de los años que exîste, se hallase macizado de la misma piedra; que las tierras que baña el agua creciesen sensiblemente en altura, respecto de las otras inmediatas que no baña; y que los surcideros que están al igual de ella se tapasen, y sucesivamente se abriesen por otros parages mas altos de la montaña; pero no hay tradicion de que haya sucedido; y así no hay indicios de la mutacion del agua en piedra, no obstante las incrustaciones que se ven de ella.

I9 La parte baxa es sumamente escasa de manantiales, y los que hay están en las pendientes de la alta. La falta de lluvia y de congelarse hielos no permite que haya depósitos de ella: la igualdad del pais es otro impedimento: y así se diferencian tambien en esto, pues lo que mas abunda en la alta es lo que mas escasea en la baxa, la qual no podria. subsistir si no le contribuyese la abundancia de rios de la otra que la bañan para fertilizarla.

20 En los territorios cálidos, como Panamá y costas de Cartagena, que son baxos, no son freqüentes los manantiales, y los que hay dan el agua en el mismo grado de calor que tiene el ayre, sin que la circunstancia de haber corrido por lo interior de la tierra las haga algo mas frescas, procediendo de que los veneros no están á mucha profundidad, y el calor del sol penerra hasta ellos, que es lo que se dixo tratando del temperamento de la Habana. Portovelo está rodeado de montañas de bastante altura, siendo los ramos de las cordilleras que pasan por el Ismo: allí hay abundancia de arroyos, cuyas aguas son muy delgadas, puras y cristalinas; y son asimismo algo mas frescas que el temperamento del ayre, aun- 
aunque la diferencia no es mucha: la misma causa que concurre para que los manantiales de terrenos baxos en aquellos climas se hallen en el grado de su temperamento, contribuye por el contrario para que en Portovelo sean diferentes en las montañas de alguna altura; no hace tanta impresion el calor como en las llanadas baxas. A proporcion de la altura son los veneros mas profundos, y alcanza ménos parte de calor; y por conseqüencia el agua lo percibe ménos; y quando sale de ellos se siente con alguna frescura, que no llega á ser frialdad.

2 I Las aguas del rio Misisipi parecen á la vista las mas impuras y nocivas; pero en realidad no lo son: de continuo están turbias, y tan sobrecargadas de limo, que al tomarlas en un vaso empiezan á hacer asiento, y se ven moverse las partículas terreas en el agua en tanta abundancia, que repugna á la vista : en el tiempo de las crecientes son muchias las palizadas que arrastra, trayéndolas de distancias muy dilatadas, unas de árboles, que tienen algo de verdor, otras de troncos grandísimos, secos y podridos en parte: esta abundancia de árboles y troncos no puede dexar de dar al agua muchas partes de la sustancia que en si contienen; pero no solo no se percibe en ella, sino que la experiencia tiene acreditado ser saludables y benéficas para la naturaleza. Entránle tambien arroyos y rios, cuyas aguas están mezcladas con materias extrañas; otras salobres, pero la porcion considerable de las suyas no da lugar á que sobresalga la mala calidad de las que recibe, predominando siempre la parte saludable. En el verano, quando se halla en su mayor menguante, están algo claras, y entónces no son tan buenas como quando está crecido, siendo la causa porque le entran las del mar á algúna mas distancia con las maréas, y hacen rebalso las dulces, sin que por esto sean 
sean perjudiciales para la salud. Entónces se sienten calientes por la superficie, pero en lo profundo mantienen la frescura.

22 Siendo tan limosas como se ha explicado, no engendran piedra, debiéndose suponer, que por mas clarificada que esté, siempre dexa muestras de contener algun limo: de ordinario se llenan varias vasijas para que tenga tiempo de sentarse, y se bebe de la mas antigua: esta misma, despues de reposada, aunque sea por tiempo de un año, tomada en algun vaso, no se le descubre á la vista señal de cuerpo extraño, porque se reconoce tan diáfana y pura como el cristal mas trasparente, y dexada allí uno ó dos dias, se ve en el ásiento un limo sutilísimo, que parece xabon, el qual se nota tambien sobrenadar en las vasijas grandes donde se pone para que se aclare. La gente comun, y la que trafica por el rio, la bebe turbia como viene naturalmente, $y$ no hay. exemplar de que les haya ocasionado mal, aun usándola quando se hallan fatigados y sudados del trabajo de remar.

23 La qualidad fria que tiene puede proceder de venir de las partes del Norte, y de las muchas nieves que se derriten en ellas, que son, segun lo que puede juzgarse, las que le dan orígen: desde ellas sigue recogiendo las de aquellas dilatadísimas llanuras, que tiran hácia el Poniente y Norte de los 45 grados en adelante; en cuyo largo curso, y en el que hacen los otros rios que lo engruesan, se carga de las partes limosas de aquellos territorios, y á fuerza de mantenerlas agitadas con el movimiento de tanto viage, las adelgaza y sutiliza en los términos que se ven; pues miradas en el vaso parecen como un humo que ocupa su capacidad. Esta misma sutileza del limo, siendo de tal modo ligero, es sin duda la que comunica al agua la qualidad saludable 
ble para que facilite la digestion, avive el apetito, y mantenga la salud sin las intercadencias que se experimentan con las que no son tan buenas.

24 Obsérvase allí con las aguas de las lluvias una particularidad, que no se oye de otras partes, y es, qua en ciertos tiempos, quando son mas abandantes, se ve sobre ella una nata amarilla, que parece azufre; esta la hay en los charcos y en las vasijas de madera que usan para recibirla; es en bastante abundancia, recogiéndose hácia los bordes en la que está detenida. Aquella atmósfera parece que abunda de partículas sulfúreas, y lo acreditan las fuertes tempestades que se experimentan, siendo muy raro el que llueva sin que acompañe alguna con formidables truenos, que hacen estremecer los edificios. Segun lo que dicta la experiencia, trae el orígen de los bosques espesos de árboles, que abundan en resinas, los quales exhalan lo mas sutil, y en estas materias van mezcladas las partes azufrosas sutiles, que siendo en mucha abundancia, se incorporan $y$, precipitan con la nube que da el aguacero y tempestad. Esta nata ó azufre es tan ordinaria, que desde luego está visible, y en unas ocasiones se nota mas abundante que en otras, procediendo de aquí la vulgaridad allí esparcida de que llueve agua y azufre, aunque no pueda tomarse mas que por la parte oleosa sutil de él.

25 El rio, cuyas aguas quando crece se ponen mas altas que el teritorio vecino, y 10 inundan en las partes donde no tiene malecon ó dique que làs contenga, sirve de mucho beneficio en aquel pais, donde toman las que necesitan; y conducidas por cequiones ó canales, las aprovechan para los molinos ó sierras de aserrar madera, siendo una de las principales industrias que tienen aquellos vecinos. Aunque es $\tan$ caudaloso y ancho el rio Misisipi, se re$\mathrm{V} 2$

$\mathrm{pa}-$ 
para, contra lo regular de otros, no hacer mayores es. tragos en las orillas, lo qual se atribuye á la profundidad que tiene, y que por esta razon lleva la mayor fuerza su corriente por la parte baxa del cauce, como que allí es en donde concurre todo el peso y rapidez: por esto los diques ó malecones que hacen para evitar que se explaye, no son anchos, ni se les da mas altura que la que toma el agua en su mayor creciente.

26 Estas aguas que se toman del rio, y las que se juntan con las lluvias, van á dar á los lagos en la extension que tiene la isla donde está situado el Nuevo Orleans, que desde la embocadura del rio hasta el caño que llaman impropiamente Rio de Ivervila, es de 68 leguas del Sueste al Norueste, contando las vueltas que hace. El declive que las tierras tienen llevando los desagües hácia el lado de los lagos, hace perceptible que el limo que el rio depone levanta con la continuacion las tierras que baña, y juntamente su cauce; de donde procede aquella inclinacion hácia la parte que está mas distante. Parece por las señales, que el cauce se levanta al igual que las tierras de su inmediacion, dándolo á conocer la circunstancia de necesitar siempre de un malecon ó dique que lo contenga para que no inunde las poblaciones, ni los lugares que se desmontan para el cultivo; no conociéndose diferencia de la altura que tenia en los tiempos pasados á la que tiene en los presentes.

27 En la desembocadura al mar hay tambien alguna señal de levantarse el cauce; y consiste en que 50 años ha tenia 24 pies de agua la barra, y al presente solo tiene 12 en las mareas llenas, conservando por la parte de adentro la misma profundidad que tenia entónces. Bien pudiera suceder que la barra, en las distintas desembocaduras que tiene el rio, creciese en altura, sin que el cauce se levantase; 
pero siendo uno mismo el volumen de agua que llevaba en lo antiguo que el que lleva al presente, y consiguientemente igual la fuerza de esta contra los embates de las olas, parece que no hay razon para que ahora se detengan las arenas sobre aquel nivel en mas cantidad que entórces; y parece mas regular que sea el cauce el que se haya levantado, lo qual contribuye á que estén mas extendidas, y que lleven ménos fuerza que quando salian por canales mas reducidos y profundos.

28 Llama la atencion sobre las aguas, de que se ha dado noticia, y de sus qualidades, una curiosa comparacion entre las calientes de la parte alta del Perú, y particularmente en el Gobierno de Guancavelica, y estas de que acaba de tratarse: aquellas son cristalinas, trasparentes, y puras á la vista; y no obstante esto que manifiestan en la apariencia, forman canteras de los territorios que bañan, reduciendo á la misma especie las cosas que caen en ellas: estas otras son turbias, sobrecargadas de limo, de tierras, y de las partes gomosas de los árboles, y no ocasionan piedra á los que la beben, ni resulta otro algun mal, pues se ha dicho ser saludables y buenas. Estas dos opuestas propiedades, que recaen sobre accidentes encontrados, no pueden proceder de otra razon, que de contener las primeras, en partes inperceptibles á la vista, unas materias propias á unir y endurecer la tierra luego que se detienen en sus porosidades, y que el limo de las segundas, por el contrario, subsiste en partículas muy menudas, que sobrenadan, y no se unen, ni forman concrecion; pero siempre es particular por el engaño que causan á la vista unas y otras.

29 Aquellos lagos Borgne, Pontchartrain, y Maurepas, que por la parte del Norte y Levante circundan la isla del Nuevo Orleans, son la entrada del 
mar; entre ella y la tierra firme, cuyo paso llaman el Rigole, y su anchura es competente para que puedan entrar toda suerte de embarcaciones: hácia la parte del mar tiene de I6 á I 8 pies de agua, pero en todo su largo hay de io á iz brazás: de esta profundidad se vuelve á disminuir á I I ó I 2 pies, que es la que tiene el lago Pontchartrain: despues de este el Maurepas, á donde se entra de él; de suerte que la distancia que hace aquella garganta, cuyo largo es de tres leguas, hace un pozo, que excede en profundidad á su entrada y salida en 50 pies por lo ménos. El primero de los tres lagos, llamado Borgne ó Tuerco, es ménos profundo que los otros dos, no teniendo mas que de 6 á 8 pies sus aguas hácia el lado de Levante, y aunque son dulces, son gruesas, de mal olor y gusto, de un color verdoso, al modo que lo están las encharcadas: desde la medianía hácia el Poniente son del color de las del rio, y buenas para beber. Esta diferencia viene de que por este lado no le entran caños ó esteros, que vicien la calidad de los derrames del $\mathrm{Mi}$ sisipi, y por el opuesto sí. De este lago se sale al mar, é inmediato á su embocadura está el Rigole, que es la entrada á los otros dos Pontchartrain y Maurepas: sus aguas son saladas, mezcladas con las dulces que caen en ellos por varios esteros ó caños que les entran, donde se recogen las de la isla del Nuevo Orleans.

$3^{0}$ Descúbrese horizonte en todos tres; y aunque su profundidad es poca, se agita el agua lo bastante quando sobreviene tormenta de vicnto. Las embarcaciones que los navegan son pequeñas, con cubierta, no permitiendo las de mayor porte el agua y las barras que tienen los caños de San Juan Tiguyu, y otros que van á dar cerca del Nuevo Orleans, en las quales solo hay de uno y medio á dos pies: 
ples: son muy abundantes de pescados de varias especies y buenos, con particularidad los que llaman P'ges colorados, que son grandes: de estos lagos se provee el Nuevo Orleans y aquellos habitantes que están en las orillas del Misisipi.

3 I Cada pais tiene sus costumbres y usos particulares; sucediendo lo mismo con las diversidades de las gentes. En el Nuevo Orleans, molestados sus habitadores de los grandes calores, y convidados de las proporciones que ofrecen los lagos en la bondad del suelo y peca profundidad de sus orillas, es uno de los entretenimientos que practican ir á bañarse y pescar. Para esto van á ellos en barquitos pequeños; y sin despojarse de la ropa se meten en el agua, por la qual corretean y juegan, haciéndose varias burlas, como si estuviesen en tierra. La ropa no les incomoda, por ser delgada la que usan; y pueden pasearse hasta larga distancia de la orilla sin mojarse mas arrita de la cintura, porque hasta estar bien apartados de ella es el fondo igual, siendo despues de esta distancia quando empieza á reconocerse la profundidad. Tendiendo las redes los pescadores, se divierten las personas que están de paséo en tirarlas hasta la orilla, y ver salir el pescado que va en ellas: esto se repite las mañanas enteras, sin que resulte daño. Despues se retiran á las casas de los mismos pescadores que hay allí, donde mudan de ropa, y concluyen la funcion con la comida, que se prepara en mucha parte de los pescados que se han cogido. El lago Pontchartrain está en buena proporcion para estos paseos, que se concluyen en el mismo dia pasando á él por el Caño de S. Juan. 
I60

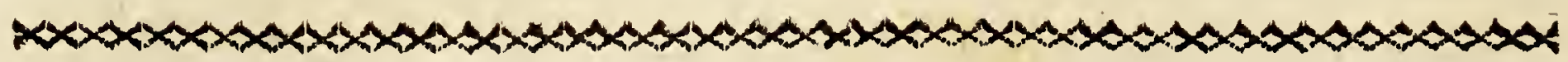

\section{ENTRETENIMIENTO XI.}

De las dolencias que son particulares, segun la variedad de los climas, y su comparacion.

- $\mathbb{E}_{s}$ regular que la naturaleza de las gentes y los animales participe de lds distintas qualidades de los temperamentos; y que, segun la variedad de estos, sea la disposicion de lis humores, y propension á las dolencias que predominan en ellos. Los temperamentos frios están preservados de muchas de las enfermedades que reynan en los cálidos, y en estos son comunes las contrarias á las que allá son ordinarias: en unos proceden de la constipacion, de la falta de transpiracion, de la coagulacion de los humores, y de la demasiada tension y entumecimiento que sufren las fibras: en los otros de la mucha disipacion de laxîtud de estas: de la agitacion de los fluidos, y de la corrupcion puede decirse, que en el primer caso la naturaleza se halla demasiado comprimida, y que en el segundo peca por muy relaxada. Los territorios que están fuera de la Zona Tórrida participan de ambas intemperies con otro exceso distinto, procedido de pasar de un extremo al otro, pues en el verano se experimentan los efectos del calor; y en el invierno los del frio, sin mas intermedio que la primavera y el otoño, que son los que preparan para pasar á ellos.

2 La diferencia de temperamento del invierno al verano en las cercanías de la Equinocial, y aun en la que coge la Zona Tórrida, no son considerables; y así se observa en la parte alta, como en la baxa del $\mathrm{Pe}$ - 
Perú; de aquí nace, que las intercadencias de la salud son quasi las misimas en todas estaciones, con la diferencia de ser en unas mas repetidas que en otras; pero la naturaleza trabaja ménos, porque no pasa de una especie de temple á otro enteramente opuesto. La juventud está muy expuesta en los climas cálidos por la disposicion que tiene á la fermentacion de los humores. La vejez se mantiene bien, $y$ adquiere otras fuerzas distintas de las que tendria en donde el clima no guarda estabilidad: unos y otros viven sin mayores incomodidades en los que son frios, porque una vez connaturalizados á ellos, no tienen que fatigarse en acomodarse á las extremas desigualdades de las dos estaciones opuestas.

3 En la parte alta del Perú se dice comunmente, que el que va sano se mantiene en el mismo estado; pero que el que lleva enfermedad padece mas que en el parage de donde la sacó: esto no sucede con todas, pues hay algunas que se curan solo con la mudanza del clima. En la parte baxa no es asi, porque hay enfermedades que quando el grado de calor aumenta, sobrevienen á los que están sanos del mismo modo que á los que padecen males habituales. Hay no obstante una diferencia entre estos climas calurosos y los que pasan de un extremo al otro, y es, que habiéndose habituado á ellos con la larga residencia, no viven tan expuestos; y así todas las incomodidades se sobrellevan, y nunca son tan penosas como el salir de un invierno crudo, y entrar en un verano caluroso, exercitando la robustez con prucbas de enfermedades y epidemias encontradas.

4 Son las enfermedades ordinarias de la parte alta las que provienen de constipaciones, afectos de pecho, pleuresías, y algunos reumatismos. Estas son mas ó ménos graves, segun la disposicion en que $X$ 
encuentran los sugetos; y quando están bien humorados no es regular que les sobrevengan. Las fiebres intermitentes $\mathrm{y}$ las putridas no reynan allí; pero se nota en ellos que los que van de la parte baxa las llevan, y ainque parezcan sanos, á cortos dias de llegados se manifiestan, causando accidentes penosísimos, que en algunos son de peligro, pero no se comunican á otros, ni trascienden á las gentes que están acostumbradas al pais.

5 En las quebradas profundas de aquella misma parte, donde se produce la caña de azúcar, sucede por el contrario; las fiebres intermitentes son comunes; siendo tal el estrago que causan, que llegan á despoblarse las haciendas por la mortandad que ocasionan en los Indios, y demas gente que las habita. Esta enfermedad es maligna, á distincion de las fiebres de la parte baxa, que aunque sean molestas por la duracion, no suelen ser de peligro; sin ser remedio suficiente salir de allí, y pasar á curarlas al temperamento frio; porque esto prueba en unos, y en otros no.

6 En algun modo tiene semejanza con la intemperie de algunas partes de Italia en quanto á contraerse con facilidad, y á reynar por tiempos, dexando de molestar en otros. Quando está en vigor, basta hacer mansion en la quebrada para contagiarse; y si llega á dormirse en ella, sea de dia ó de noche, es infalible contraer el mal; por esto los que caminan no excusan rodear algunas leguas, yendo á buscar la cabecera de las quebradas para evitar el tránsito por ellas; y los que mas se arriesgan lo hacen sin detenerse en el camino, procurando atravesarlas en horas que sea lo ménos nociva que se pueda. De continuo se padece este mal en tales parages, pero no son malignas en todo tiempo: hay algunos en que se declaran tales, lo qual dura uno, 
$U N D E C 1 M O$

163

dos, ó mas años, en cuyo término se despueblan, muriendo la mayor parte de la gente, y huyendo la poca que queda, despues de haber visto los estragos y su permanencia; de suerte, que hacen al fin lo que deberian practicar en el principio. Pasado algun intervalo de tiempo vuelven á quedar habitables, y se pueblan de nuevo con aquellos restos que saliéron fugitivos, y otros que se les agregan, sin embargo de no ser nunca sanos. La causa de esto es natural: aquellos lugares están profundos, no se ventilan: los vientos corren segun las quebradas van, unas veces de un lado, otras del contrario; y así los vapores que se levantan del rio, los que salen de las tierras húmedas y movidas para la cultura de los cañaverales, y los que esta misma planta exhala, y la reverberacion del sol en aquellos sitios encerrados, se junta todo para inficionar el ayre, y hacer el temple enfermo. Despues que se despueblan cesan la cultura y labranza de las tierras, los plantíos de cañas, los humos del caldo de estas en las oficinaś donde se reduce á azúcar, los bagazos, y las heces de aquel, que todo se corrompe, y ayuda á inficionar el ayre: por esto, despues que pasa algun tiempo de la despoblacion, cesa el mal ayre, y vuelve el temperamento al estado regular de un clima caluroso, propenso á las enfermedades que son ordinarias en los de su especie.

7 En la misma parte alta, fuera de las quebradas, siendo las enfermedades comunes del pecho, suelen ocasionar asmas, pero viven con ella los que las padecen mucho tiempo; allí la dan el nombre de abogidos. El remedio mas propio que se conoce es ir á la parte baxa, así como los que la contraen allá convalecen mudando de ayre á la alta: en los unos el demasiado resorte y compresion de las fibras, y la sutileza del ayre, ocasiona la enfermedad; en los otros $\mathrm{X}_{2}$

pro- 
procede de un ayre muy denso, pesado, y de la de bilidad de las fibras; por esto, mudando de clima los unos á donde el ayre es mas pesado y cálido, y los otros á donde es sutil y frio, consiguen mejoría, y que no les moleste tanto el accidente.

8 Dos causas hay en aquella parte alta para que la naturaleza se debilite, sin que le aprovechen las prerogativas del clima : una es el mal venéreo, que está muy propagado; otra el uso inmoderado de las bebidas espiritosas: sin ellas vivirian las gentes con mucha robustez, y sin experimentar las indisposiciones y achaques que padecen: así se ve, que las pleuresias, los ahogidos, y las fiuxiones de pecho sobrevienen regularmente á los que están tocados de aquel mal, y á los que usan con desorden las bebidas.

9 Esto se advierte mas bien en el tiempo de los hielos, y se confirmó en el año de I759: en una epidemia general que sobrevino, en la que pereciéron los que estaban con mala disposicion; y al contrario, de los que no padecian de aquel mal, ni estaban habituados con exceso á las bebidas, aunque lo padeciéron no peligráron.

Io El estrago que hizo en los Indios fué considerable, ayudando á esto la demasía con que se entregan á la embriaguez: á estos sucedia que desde los principios del mal se aparataban de muerte, $y$ duraban pocos dias: conocido este daño, se prohibió la venta del aguardiente, y luego se sintió el beneficio, cesando la mortandad; $y$ aunque la epidemia continuó, no eran tan fatales sus estragos.

I 1 Pudiera tomarse por anuncio de este mal, si se reputasen por seguras las ideas antiguas, la aparicion del cometa que se vió entónces, con corta diferencia de meses: este apareció en aquellas partes desde 25 de Abril, llevando su curso de las partes 
UNDECIMO.

meridionales á las septentrionales: la epidemia $\quad 16:$ claró en Guancavelica, hácia los fines de Julio decorrió toda aquella vasta extension de pais zando igualmente en lasta pais; empede fué de fue sucesivamente siguiendo á las septentrionales; y como si fuese cosa viagera, pasaba de unas ciudades á otras, conociéndose por la distancia de estas, á corta diferencia, lo que tardaria en llegar á las de mas adelante: su principio fué, como va dicho, en las partes del Sur; pero como aquellos paises son de tanta extension, quando se tuvo la noticia en las mas cercanas á la Equínocial fué al tiempo que estaba en Potosí y Chuquisaca: de allí pasó á la Paz, á Oruro, Chucuito, el Cuzco, Guamanga, Guancavelica, Xauja y Lima; y fué siguiendo despues por los territorios alto y baxo hácia Quito. y demas Provincias. Sus progresos eran rapidísimos, de tal forma, que si hubiese tenido la malignidad á correspondencia de la generalidad, sería bastante para la exterminacion del género humano en quanto comprehendió, pues en el término de cinco ó seis dias no quedaba persona grande ni pequeña, que no adoleciese de ella, manifestándose en unas con mas rigor que en otras: las calles quedaban desiertas, siendo raras las personas que en ellas se veian: las casas solitarias, y postrados quantos vivian en ellas: las plazas de la provision totalmente yermas, sin haber ni quien vendiese, ni pudiese ir á comprar; y en este conflicto fal aba la regular asistencia, porque todos estaban en el caso de necesitarla. La providencia de Dios permitió que lo fuerte del mal durase á las personas bien complexionadas solo dos ó tres dias, $y$ aunque quedaban con una debilidad extraordinaria, podian en algun modo dar auxílio á las que se hallaban mas agravadas.

I2 El mal consistia en un gran desvanecimien- 
to y pesadez de cabeza, flaqueza en todos los sentidos, y dolores fuertes en el cuerpo, indistintamente en las partes de él; calentura no muy violenta, laxîtud general, sangre por boca y narices, sordera y un gran abatimiento, con total inapetencia: á los que padecian males habituales, particularmente del pecho, se les agravaban; y alargándoseles la enfermedad, morian; los que no estaban en aquel estado mejoraban usando de sudoríficos y de abrigo para mover la transpiracion: despues de pasado lo fuerte del mal se sentian en la convalecencia los efectos de él, siendo larga y penosa, porque quedaban débiles los cuerpos, la vista perturbada, el aspecto triste, y el ánimo abatido, necesitándose mas de un mes para disipar estas reliquias.

I3 Observóse entónces que los perros participáron del mal epidémico: en las calles se veian tendidos, sin poderse poner en pie; algunos muriéron; pero se observó que tambien fué benigno para con ellos.

I4 Así como fué rápido en empezar y en propagarse en los vecindarios de las poblaciones, donde picaba, fué pronto en terminarse, cesando en cosa de un mes. En las partes por donde empezó fué mayor la mortandad, por faltar el conocimiento de la curacion; observándose que el uso de las sangrías era pernicioso y aun mortal, con cuyo antecedente, sin embargo de los grandes aparatos que le acompañaban, se reducia despues la curacion al método que se ha dicho.

I5 En aquellas partes no conocen la enfermedad de la peste, ni tienen en lo comun idea de ella: con esta escasez de noticia, la aplicáron el nombre de tal, como lo hacen en todas las enfermedades epidémicas, las quales se experimentan por tiempos, y son mas comunes en la parte baxa que en la alta. 
UNDECIMO.

La causa del mal, segun toda apariencia, estaba el ayre; y entre las señales que lo persuaden, lo es el que en aquel mes, y desde fines de Abril, reynan los vientos Sures arriba, y la epidemia corria, como ellos, del Sur al Norte; porque si no fuese asi, y la comunicacion procediese solo del contagio de unas personas á otras, no las comprehenderia tan generalmente como sucedia, y ménos á los irracionales que van expresados.

I6 En los parages cálidos de la parte baxa es enfermedad comun la de las tercianas, ó fiebres intermitentes; duran mucho tiempo en las personas á quienes dan, pero sin la malignidad que las de las quebradas de la alta; y aunque no dexan de morir algunos, es quando se les complican con otros males, ó despues de largo tiempo de padecerlas, sin hacerse cura formal que lo extinga; y así acaece á muchos, que viviendo en aquellos campos esparcidos, $y$, lejos de las poblaciones principales, no tienen proporcion para ella.

I7 Este género de enfermedad es sin duda el mas comun en los parages que por naturaleza son cálidos, ó participan de veranos calurosos, y en los primeros son tenaces y difíciles de extinguirse. La gente del campo, en la isla de Cuba, tiene una observacion particular, y es, que quando se mojan, yendo de camino, si el agua les cae sobre la ropa, aunque sea en poca cantidad, juzgan por seguro que les han de sobrevenir tercianas, pero no asi recibiéndola sobre las carnes; y que quanto mas copioso es el aguacero, ménos riesgo hay de que les haga mal: por esto, luego que empieza á llover se quitan la ropa que llevan, que es bien ligera, y quedan de la cintura arriba en cueros, afirmando ser esto lo mismo que bañarse; y que lavándose el cuerpo por igual, no experimentan el daño que percibiendo la humedad 


\section{8}

dad de la ropa, durante el tiempo que caminan, y. el calor que comunica quando está mojada.

I 8 El pais de la Luisiana es propenso á la misma dolencia en tiempo de verano: quando los calores son fuertes, y las lluvias ó turbionadas, ó borrascas pasageras, muere bastante gente de ellas, á causa de que algunas son malignas, lo que procede tambien de la falta de curacion; pero luego que se declara el frio con los primeros Nortes en Noviembre, cesan y se convalece de ellas la mayor parte, sin otro medicamento mas que la mudanza del temperamento.

19 La enfermedad que llaman de siete dias en las criaturas recien nacidas, es general en ambas Américas, y no ménos peligrosa en la parte alta que en la baxa: muchas de las que nacen perecen con él, y aun sin tener antecedente para sospecharlo: hallándose, al parecer, sanas y robustas les sobreviene este mal acompañado de alferecía; y es muy raro el que escapa si llega á darle. Aunque en Europa se conoce igualmente, no es tan general, ni tan grave como en aquellas partes; y por esto acostumbran resguardarlos del viento, hasta que pase aquel término, fuera del qual quedan libres: de aquí viene llamarle de siete dias, porque dura el peligro este tiempo.

20 En Guancavelica hay otra enfermedad en los niños bien rara: salidos del peligro de los siete dias, se crian regularmente hasta que tienen tres ó quatro meses: entónces empiezan á padecer de tos y afecto al pecho, que llaman allí pecbuguera; van agravándose, sin que los medicamentos que se les aplican les alivien: á esto sigue el hincharse, y á poco de estarlo mueren. Este estrago se experimenta con los blancos hijos de Españoles, no sucediendo lo mismo con los Indios y Mestizos, cuya resistencia es mayor. El modo de precaverlos es sacarlos de allí án- 
tes que pasen de los dos meses, y llevarlos á climas mas benignos en alguna de aquellas quebradas, qué están á poca distancia: la vulgaridad atribuye esta poca resistencia á la frialdad é intemperie del clima: en mucho puede contribuir; pero tambien es parte de cllo el estar los padres mal humorados, y los humos azufrosos que se respiran de continuo, procedidos de los hornos en donde se extrae el azogue, los quales son en tanta abundancia, que en tiempo de verano con los hielos forman nube densa, que cubre el ámbito de la poblacion.

2 I Las lombrices, en toda suerte de personas grandes y pequeñas, es enfermedad muy comun en la Luisiana, y de las diversas castas que hay de ellas se padecen las mas, quando no sea de todas, sin excluirse el toenia, ó solitario: la causa que esto tenga pueden ser las grandes humedades de aquel territorio, la abundancia de semillas de insectos y reptiles que allí hay, y la calidad de los alimentos; pues se observa con la fruta, particularmente con las de hueso, y con las legumbres, que no duran; y á los dos dias de cortadas se empiezan á podrir y se corrompen, procedido de ser de un terreno enaguazado, y de una atmósfera siempre húmeda: con esta enfermedad sobrevienen fuertes calenturas, mucho descaecimiento, languidez, y melancolía: Ia curacion que se tiene mas conocida es el zumo de la yerba llamada bedionda, ó de lombrices, que ya se ha nombrado. Tambien usan el aceyte de nueces, que en algunos hace buen efecto; pero se nota que no todas las personas curan radicalmente, repitiéndoles despues de pasado algun tiempo.

22 Las viruelas, enfermedad tan conocida por lo muy propagada que está en el mundo, no ménos que por los lastimosos extragos que causa, tiene sus tiempos. En todo el Perú, no siendo anuaX. les, 
les, como sucede en Europa, se pasan varios años sin haberlas; pero quando reynan ocasionan mucha mortandad, no solo en los Blancos, que allí llaman Españoles, sí tambien en los Indios y Negros: el año de 64 las hubo en la parte baxa, y pereció mucha gente de todas edades, experimentando este quebranto las principales familias de aquel reyno. Aunque los climas son tan diversos, no puede hacerse juicio de que sean mas malignas las de la parte alra que las de la otra, mediante que en una y otra fué crecido el número de los que muriéron. En la alta suelen usar un método de curarlas muy contrario á las precauciones que se han acostumbrado en Europa, porque las Indias no resguardan del ayre á sus hijos quando las padecen, y'los tienen acostados junto á sí sobre alguna zaléa, con el poco abrigo que usan; pero aunque aquel clima es tan frio, no mueren mas de este modo que de los que se resguardan con las precauciones mas escrupulosas: á esto se junta no usar ellos el auxîlio de Médico ni de medicina, dexando á la naturaleza que haga toda la costa : quando mas, se valen de algunas yerbas que conocen, y estas se las aplican, como si fuera sanalo-todo, á quantas enfermedades les sobrevienen. Quando las viruelas les cogen grandes, son pocos los que escapan, porque teniendo el cutis grueso, encuentra el humor impedimento, y no se hace con regularidad la crupcion: por esta razon son mas temibles en ellos que en las otras gentes, causándoles horrible desolacion. No lo serian tanto, ni tan generales sus estragos, si las hubiese anualmente, pues entónces las pasarian de poca edad, y no moririan tantos, acreditándolo así la experiencia en los que encuentra pequeños.

23 Sobre este particular imprimió Monsieur de la Condamine, de la Academia Real de las Ciencias 
y de la de Bellas Letras, en el año de r764, cinco Cartas que escribió al Doctor Macy, de la Sociedad Real de Londres, dándole noticia del estado en que se hallaba la controversia sobre la utilidad. de la inoculacion en aquella capital, y los fundamentos del partido que la sostenia. En estas Cartas desvanece los recelos que hasta entónces se tenian del peligro á que voluntariamente se exponian los que se inoculaban, y el concepto de no quedar preservados, para no volverlos á padecer por contagio; cuyos exemplares son los mismos que han dado lugar á los de la Nueva Inglaterra para hacer general esta operacion, que se halla no ménos puesta en uso en la. Vieja.

24 En los territorios cálidos de la Zona Tórrida no son tan perniciosas; pero quando median algunos años sin haberlas, causan bastante mortandad: esto mismo se observa en la Luisiana, concluyéndose de ello, que no es felicidad el que intervengan diez ó doce años sin sentirse sus efectos, si al cabo de ellos es mas sensible el daño: sin duda ha contribuido este conocimiento en la Nueva Inglaterra para el uso público de la inoculacion establecida allí, por cuyo medio se precaven desde la edad pueril, quedando para en adelante sin los temores de peligrar en las viruelas; $y$ es tan corriente, que hay casas públicas y hospitales donde se practican con el mayor acierto en toda clase de personas. Con este motivo acuden tambien de fuera, y de la Luisiana ha habido varias, que en una edad crecida. se han hecho inocular allá. Muy conveniente sería que de los paises donde no se conocen bastantemente las grandes ventajas de esta providencia preservativa, se diputasen Médicos hábiles para que fuesen á exâminar las resultas que tienen los inoculados durante el curso de la operacion: que se asegura$\mathrm{Y} 2$

sen 


\section{I72}

ENTRETENIMIENTO

sen por el quantioso número de los que la han pasado, si quedan con el mismo peligro de padecerla en las grandes epidemias; $y$ en caso de esta reincidencia, de qué calidad son, si benignas ó perniciosas; si con la providencia de estar inoculados todos, ó los mas, se extingue la causa epidémica; el método de preparar, é introducir la semilla; la eleccion de la que usan; las precauciones que se guardan durante sus efectos; la estacion del año mas propicia; el temperamento, y aquellas otras circunstancias que conducen al pleno conocimiento de este asunto; por donde pudiera preservarse de perecer la mitad ó la tercera parte de las criaturas que nacen en cada estado, grande ó pequeño; y lo que es mas que todo, las cabezas de los Imperios, y sus felices sucesiones, pues con unas observaciones, practicadas por sugetos de conocida reputacion, sabiduría y concepto, se desvanecerian los reparos y contradicciones que ofrece la novedad de esta invencion, que se hace repugnante por recaer en un mal, cuyas conseqüencias son fatales.

25 Así como los afectos de pecho son comunes en la parte alta, lo es tambien el arrojar sangre por la boca, lo qual sucede en los parages mas frios. En Guancavelica es bastante ordinario, y viven con ella algunos años: suelen los que lo padecen sanar enteramente pasando á otro temperamento ménos rígido; pero otros mueren, sin que haya regla fixa en quanto á la duracion. Aquel no es temperamento de héticos, sin embargo de lo que se padece del pecho, siendo raro verse alguno; por el contrario, el territorio baxo es propenso á ellos, no siendo comun el arrojar sangre. En la Luisiana se padece bastante de ambas enfermedades, abrazando en esta parte los dos males mas peligrosos de los territorios alto y baxo del Perú. 
26 El accidente del pasmo es temible en la parte baxa del Perú por la facilidad que hay de contraerlo, y por ser mortal: lo primero sucede con muy ligero motivo, no siendo capaz de tenerlos presentes para precaverse de todos; basta salir algo caluroso de una pieza, y que dé el ayre, para que se siga el pasmo. Esto no sucede siempre, pero es una de las causas : otra es salir al ayre, ó ponerse en donde haya correspondencia acabados de beber el mate, que es al modo del té: en la parte alta no se conoce tal enfermedad; y siendo como inevitable quando ha habido alguna picadura en las plantas de los pies, que sin reflexion se mojan, ó se humedecen, no corre este peligro en la otra. En la isla de Cuba, y en todos aquellos temperamentos cálidos, es igualmente peligroso, sin que se conozca curacion segura contra ello, siendo raro el que escapa. En la Habana no obstante se citan modernamente algunos exemplares de haber curado; pero el método no se halla tan entablado, que no sea siempre arriesgado. De esta enfermedad participa algo la Luisiana en los casos de picadura, pero sin ella no la hay.

27 Goza tambien la parte alta del Perú el beneficio de no ser comunes en ella las perlesías, que allí llaman ayre; y aunque del todo no faltan, no son tan freqüentes como en la baxa: esto procede de la igualdad del temperamento y de ser siempre frio, sin mutacion de invierno ni de verano, y de estar los poros del cuerpo cerrados, en disposicion de resistir la introduccion del ayre; así quando sobreviene semejante accidente, es en personas de avanzada edad, que ya se sienten achacosas. Los insultos apopléticos son rarísimos; y en este particular no es ménos favorecido el un pais que el otro; en el discurso de muchos años no se oyen estos casos, 
cuyo beneficio debe tambien atribuirse á la poca variedad en el temperamento entre las dos estaciones opuestas, pues los humores se conservan en un mismo ser, los alimentos no varían, y el ayre que se respira es, á corta diferencia, el mismo. Sentados estos principios, es necesario que en la atmósfera haya cuerpos desconocidos perceptibles, que son la causa de los pasmos, pues de otro modo: podria sobrevenir una constipacion de aquellos ligeros descuidos, pero no una contraccion tan terrible como la del pasmo, y la muerte que se sigue á ella en término de cortos dias.

28 Siendo, como queda dicho, las pleuresías el mal peligroso de aquellos climas frios de la parte alta, no son estas muy comunes en las personas bien complexionadas, pero sí en las que se hallan mal dispuestas de las enfermedades venéreas, ó de la fuer$\mathrm{za}$ de los licores espiritosos. Se conoce por remedio eficacísimo contra ellas el hígado del zorrillo, tomado por la boca, y se ven curas prodigiosas. No es del caso que sea fresco ó viejo, porque de todos modos son seguros sus efectos, y dicen, que habiéndolo usado quedan asegurados para que en lo sucesivo no repita el mismo mal.

29 En la vida desarreglada de los Indios, que tienen por único deleyte la embriaguez, y pasa toda comparacion el aguardiente que beben, no se ve que sean propensos á pleuresías, ni á otras enfermedades del pecho, cuya particularidad debe atribuirse á la fortaleza de su complexîn, y á ser muy: raro en ellos el mal venéreo.

$3^{\circ}$ Es bastante comun en los climas cálidos el de la lepra, conocido por mal de S. Lázaro: en la parte alta del Perú no se conoce; en la baxa, aunque lo hay, no es en abundancia: en las costas de Tierra-Firme, que corresponden al Norte, se pro- 
propaga lo bastante, y en la Habana es una de las partes donde se ven sus estragos con lastimosas conseqüiencias. Allí juzgan proceder de la calidad de la carne de puerco, que se gasta con abundancia; pretendiendo que el fruto de una especie de palma, distinguida con el nombre de real, á que llaman palmiche, y come mucho este animal, aumenta la causa. La carne que se ha mantenido con él se distingue en ser mas abundante de glandulillas que la otra, siendo estas de color negro, y desde luego son perceptibles en toda la parte del pescuezo. Aunque tal opinion corre por segura, debe mirarse como principal en el orígen la introduccion de Negros Africanos, en cuyas partes es muy antigua, y como natural. Contra semejante accidente, que por todos motivos es de los mas horrorosos, se deberian duplicar las precauciones, y emplear el mayor cuidado en que se fuese extinguiendo, para que sus estrages no fuesen comunicables. En la Luisiana no se conocia, y de poco tiempo á esta parte ha empezado á padecerse.

3 I La enfermedad de la culebrilla, muy conocida en aquellos climas cálidos, es otra que se cree haberse introducido en ellos por los Negros de Africa. Puerto del Príncipe y su territorio experimentó con mas generalidad que otros parages, aun de la misma isla de Cuba, los efectos de este mal; pero habiéndose convencido de que se adquiria por contagio, tomáron providencia para contenerlo, y fué la de quemar los trapos que servian para las curaciones; de los quales, despues de secos, resultaban infinidad de insectillos, que esparcidos por el ayre la hacian comunicable á los que estaban buenos; y con solo esta precaucion, y la de curar á los Negros recien llegados de su pais, quando se reconoce estar con clla, ha sido bastante para que no sea tan comun. 
32 Es cosa sabida que no se conoce en aquellas partes el mal de rabia en los perros, ni en algun otro animal; y esto sucede, no solo en la América Meridional, sino tambien en todas las Indias; pero en su lugar padecen otro que es general, y del que resulta mucha mortandad en ellos. Este entra en la clase de los que llaman peste: de ella no resulta la propension á morder, que la rabia les da, ni el daño de comunicarla. En algun modo es un equivalente de las viruclas en los racionales. Empiezan por ponerse tristes, no querer comer, enflaquecerse, é írseles la cabeza, de modo que se caen, y no pueden andar: en esta forma están por espacio de quince ó veinte dias, resistiendo unos mas que otros, y al fin la mayor parte muere. Les acomete de ordinario en el primer año, siendo cachorros; pero habiéndolo pasado una vez, no les repite. Los perros estimados para la caza se procuran curar, que es el modo de que escapen algunos mas: los medios que se ponen para ello es cortarles la punta del rabo ó de las orejas á fin de que desangre, y darles á comer los hígados de las reses, cocidos y mezclados con buena porcion de flor de azufre: se les unta el lomo con manteca de puerco, y se tiene cuidado de sobarlos hácia el rabo, con cuya diligencia se les ve expeler por la cortadura hecha en él, porcion de podre, á modo de filamentos, lo qual parece ser la causa del mal. El año de 67 hubo en la Luisiana una epidemia de estas, que los exterminó quasi del todo, habiendo sido muy pocos los que escapáron.

33 Otra enfermedad particular padecen las mulas, que llaman mal del bazo. Las crecidas tropas de este ganado, que se conducen del Tucuman por todo el Perú anualmente, y constan de millares de ellas, suelen tener pérdidas crecidísimas, procedidas 
de ella. El mal es en los cascos, sin tener semejanza con el hormiguillo: se les hinchan las ranillas, pasa el mal á lo interior de las piernas, y mueren: su contagio es $\tan$ eficaz, que aseguran los que hacen este trato, que solo de pisar por donde han andado las que lo tienen, se comunica. Esto procede sin duda de dexar entre las yerbas algunos il sectillos, que sean la causa del mal. Esta crecida porcion de mulas sale de los territorios del Tucuman, en tropas de dos ó tres mil, en tiempos determinados, para hacer el largo viage de 600, y aun hasta rooo leguas desde allí á la Tablada de Tucle, en la jurisdiccion de Guancavelica, que es donde se hace la feria de ellas, y pasan algunas partidas hasta el reyno de Quito. Para caminar tanta tierra eligen ir por las Punas ménos frias apovechando los pastos, y regularmente siguen unas tropas á otras; siendo el cuidado de los que van posteriores informarse si ha picado el mal en las que preceden, para extraviar viage, $y$ no ir por sus huellas en los pasos precisos, evitando así que se comunique el contagio. En cada tropa observan el mismo cuidado, separando las que se reconocen picadas, y llevándolas por sendas extraviadas para que no se inficionen las buenas.

34 No llegan estas crecidas partidas en todo su número á la Tablada de Tucle, porque ántes de salir del Tucuman tienen hechos tratos sus dueños con los Corregidores de Provincias de las cantidades que necesitan, y al tránsito las van dexando; y así solo entran aquellas que no han tenido salida hasta aquel término, y son las que despues pasan á las Provincias de los Valles, á Caxamarca, y hásta Quito.

35 En las mugeres se experimenta $\operatorname{con}$ bastante frequiencia en el Perú el mal temible del cancro, que, 
segun la opinion allí admitida, se difunde por comunicacion: sus estragos van en aumento, haciéndose mas comun cada vez : de este modo se ha propagado á la parte alta, en donde veinte ó veinte $y$ cinco años hace no se conocia. Algunas observaciones han dado indicios de que el orígen sea de Africa, por ser en las Negras y en sus generaciones mas ordinario; y que siendo estas las que sirven de amas, comuniquen con la leche á las personas blancas la disposicion á él. Esta opinion tiene dos contras: la primera el no ser regular en los otros paises de las Indias, en donde la mayor parte de las poblaciones se componen de Negros y de gente de castas: la segunda, el que las Europeas que pasan allá no están libres de él, de lo qual hay. exemplares muy autorizados. Lo que se sabe de seguro es, que sobreviene de resultas de algun grave pesar, de algun quebranto sensible que indispone el ánimo, y lo mantiene en continuo disgusto, y que en las doncellas no es regular, como en las casadas. Muy en los principios suele contenerse el progreso con freqüentes baños, con cosas humectantes, con diversion, y poco exercicio; pero es muy raro que llegándose á formar se contenga, siendo lastimosos y fatales los fines, que terminan con dolores $y$ accidentes cruelísimos, y con la vida. 


\section{ENTRETENIMIENTO XII.}

De los Minerales, principalmente de los de Plata, $y$ el modo de entablar su trabajo.

I $\mathbb{E}_{1}$ incentivo mayor de las naciones ha sido en todos tiempos las riquezas y metales preciosos, que son los medios de adquirir las demas cosas. El oro y plata tienen en sí tanta recomendacion, que sin fixarles valor seguro, se miran en el mayor aprecio aun entre las naciones que ménos los necesitan para sus tratos. Estos metales dan la ley en el mundo; y los Príncipes, según el estado actual de las cosas, no pudieran hacerse respetables si careciesen de ellos, y no se hallasen en proporcion de sostener los gastos indispensables de la soberanía. Así como dan la ley, dan el valor, arreglándose las demas cosas por la abundancia ó escasez en que ellos corren: con que son verdaderamente la balanza general entre los menesteres de la vida, que se regulan por partes pequeñísimas de ellos. En esta clase entra, como principal, el trabajo de los hombres: desde el mas alto al mas humilde no hay quien dexe de recibir la recompensa de su mérito, de su habilidad, ó de sus fatigas, en las mismas partes de ellos, proporcionadas á la entidad de las obras de cada individuo. Los Chinos trabajan incesantemente para adquirir plata, que no da su pais, siendo una de las naciones que ménos la necesita. Los Europeos afanan mucho para adquirirla, con el fin de servir á los Chinos, llevándoles lo que apetecen. Los Moros Africanos hacen continuas piraterías, anhelando á adquirir plata, y se valen del medio de esclavi$\mathrm{Z}_{2}$

zar 
zar hombres, para tener prendas que se la propor cionen, aun siendo las naciones mas bárbaras y que trafican ménos de quantas se conocen. Los Europeos se exponen á toda suerte de peligros para abastecerse de estos metales; y llenos de una emulacion interminable, se aniquilan reciprocamente en las guerras que suscitan, por el deseo de poseer la mayor porcion de ellos. Los Americanos desentrañan 12 ticrra, introduciéndose por sus profundos senos, con la esperanza de ser mas felices con el dominio de semejantes ídolos; pero son los que ménos gozan de ellos, porque insensiblemente se les desaparecen, y en brevísimo tiempo los encuentran haber hecho la mitad del giro de la tierra, pasando sin detenerse de las manos de varios poseedores á los que se hallan mas distantes. Su poderío excede en cierto modo á làs ideas de los hombres, y los precisa á que se traten unos con otros, pues sin este atractivo serian incomunicables las naciones, manteniéndose cada una en el distrito de su territorio, sin incomodarse en ir á buscar las mas remotas y ménos conocidas. Con las partes diminutas de ellos se mueven las voluntades á quanto se intenta; y acrecentándolas á medida de las dificultades, se allanan los caminos de lo que parece imposible, y se hace facil lo mas arduo.

2 Por esta razon pueden tenerse la plata y el oro por unas materias, que sirven de medida comun cntre las gentes, y estas con su incentivo se muever á distribuir el tiempo en las ocupaciones, trabajos y desvelos de la vida humana; concurriendo z este destino la disposicion de la misma naturaleza en no haberlas hecho tan comunes que se consiguiesen facilmente, pues á serlo se disminuiria su aprecio, y tambien en no haberlas depositado con igualdad en toda la tierra, á fon de que los para- 


\section{DUODECIMO.}

ges donde faltasen se valiesen de los medios correspondientes para atraérselos á expensas de la mayor industria $y$ de la constancia en la aplicacion. En todas làs partes del mundo suele haber algunos débiles indicios de estos estimados metales; pero la misma escasez con que se encuentran en las mas, ó la suma dificultad que hay para conseguirlos, los hace mas apetecibles, sirviendo aquellas cortas reliquias de muestra para que se conozcan, y que el deseo se esfuerce á lograr con abundancia lo que la suerte les repartió con escasez.

3 Las Indias Occidentales, que gozan por privilegio de las minas de plata y oro en mayor abundancia que las otras partes de la tierra juntas, tienen unos naturales, quales son los Indios, nacion de suyo la mas desidiosa y ménos aplicada á todo género de trabajo de quantas se conocen; y quando hacen alguno los que se tienen por civilizados, es á fuerza de muchos cuidados y de precisarlos á ello; pues si se les dexase enteramente á su voluntad, se pasarian los dias sin moverse de un lugar, como lo practican los no reducidos : por esto la plata y oro, que ellos mismos poseen los primeros, se les desaparecen de entre las manos, y van corriendo de dueño en dueño, sin hacer mucha mansion en ellos.

4 No solo está la dificultad de adquírir estos dos metales en su extraccion de las entrañas profundas de la tierra, sino que parece haber de propósito separado el Supremo Autor de lo criado de las otras partes de ella, con mares dilatadísimos, la que habia de lograr el privilegio de tenerlos con mas abundancia; y sobre la regular altura de su redondez hizo aquella tierra elevada, que predomina z todas las restantes, como indicando cierta analogía lo físico con lo moral; pues así como el ter- 
reno no reconoce otras elevaciones, que puedan com: parársele en la altura, no se conoce tampoco materia alguna que sirva de medida al poder, á la autoridad, al dominio, á la dignidad, al gusto, al porte, á la decencia, y descendiendo por todas las graduaciones desde la buena suerte hasta la mas desvalida mendicidad de los preciosos metales que en él se contienen.

5 Antes del descubrimiento de las Indias, y en lo que alcanza la memoria del mundo, habia oro y plata, que en todos tiempos han servido al destino que va expresado; pero despues de aquel famoso suceso, han venido á ser el poderoso incentivo de mantener á todas las naciones en movimiento, y de inducirles á un continuado empeño y emulacion para adquirirlos. La solicitud de estos metales ha sido causa de civilizarse las gentes entre si con el trato; de poblarse los mares de flotas numerosas, que navegan sobre las aguas, como si fueran Repúblicas enteras; ha adelantado las artes, sutilizado la industria, ilustrado las gentes, y les ha proporcionado el conocimiento de la tierra, que ántes estaba muy incompleto, ignorándose muchas de sus producciones propias, y sus particularidades.

6 Es cierto, que en correspondencia de estas utilidades, el descubrimiento de los tesoros ha ocasionado otras malas conseqüencias, y particularmente para la nacion en cuyo seno nacen, siendo las principales su propio descaecimiento, y las guerras repetidas que se le originan por la envidia que resulta á las demas en la pretension que cada una tiene sobre la preferencia para disfrutarlas; bien que estas es de creer no faltarian, aunque cesase la razon del incentivo que añaden las riquezas; porque siempre habria los otros que acredita la experiencia haberlo sido entre las naciones, en quienes el uso 
de estos metales no se halla introducido, por lo dificil que es contenerse los anhelos del corazon humano dentro de los límites de lo que cada qual goza y posee.

7 El reyno del Perú es uno de los grandes depósitos del mundo, donde están los metales: allí los hay de todas especies, de plomo, de cobre, de estaño, de azogue, de fliata, y de oro: los hay igualmente de los que se llaman semimetales, y los hay particulares de sal comun, de azufre y de betunes; pero se llevan la principal inclinacion los de plata y oro, como mas precioses, y como tales apetecidos con igualdad de las gentes; y.aunque en los otros tambien se trabaja, sacando el regular fruto, no es con tanta aplicacion.

8 Parece que aquella tierra elevada fué dispuesta expresamente para que sirviese de caxa, ó receptáculo de la plata, siendo particular á ella las minas; y aunque en las cabeceras de la tierra baxa no dexa de haber algunas, son pocas y de corta entidad. Ia experiencia enseña, que este metal se halla en las Punas y parages mas frios, así como es lo ordinario estar las de oro en las mas cálidos, aunque suelen encontrarse algunos en territorios que no lo son tanto. Los minerales de plata no son en el crecido número que se persuade la vulgaridad, imaginándose haberlos en cada cerro, y que solo se necesita abrirlos, y desenterrarlos para que se haga patente. Este error es provechoso, pues sirve con el engaño de incentivo para empeñarse á buscarlos por todas partes, y si unos fallan otros se aciertan.

9 La misma preocupacion que se figura ser tan comunes los minerales de plata, los supone todos ricos, y conviene tambien este segundo error; pues en tanto que se encuentra la abundancia, que la idea se promete, se saca alguna plata, no obstante de ser

con 
184

ENTRETENIMIENTO

con duplicado ó triplicado costo de su valor; la pérs dida en estos casos es para los que hacen los gastos; pero la cantidad se aumenta y en el público se goza. No hay entretenimiento mas agradable para los que se entregan á él, ni asunto en que se gasten los caudales con mas franqueza, sin quelar el remordimien to de haberlo malogrado. Embelesados los mineros en las señales de su veta, que es el nombre que dan á la mina, en la distancia que llevan trabajada, en las calidades de tierras que han ido encontrando, en la clase de metales que pintan (así llaman á la tierra, ó materias que sacan de ellas), á los visos de plata que suelen reconocerse de tiempo en tiempo, y á las historias que les refieren los que se ocupan en este exercicio, lo único que sienten quando se les acaba el caudal es no tener á su disposicion otro tanto como el que han consumido, para continuar la empresa; y así, aunque gasten mucho y recojan poco, no se consideran perdidos, contando por mas pingüe el que esperan que les produzca la mina. Algunos en el crecido número lo consiguen; y el exemplar de pocos mantiene á los demas gustosos y satisfechos de su alhaja, embelesados en conti nuar la obra, para encontrar con el tesoro. Es de tal modo la pasion que se contrae con las minas, que el hombre que llega á mezclarse en ellas, aunque sea ligeramente y por modo de ensayo, queda viciado y dispuesto á hacer el sacrificio de quanto caudal posee por el deseo de disfrutar sus riquezas, siendo el exercicio único en que no se conocen los económicos y míseros; perque en el empeŕo de llegar á lo rico de la veta donde esperan cortar la plata á cincel, y poseer un tesoro sin límites, no escasean el dinero, ni se acortan interin que les dura, $p \wedge r$ crecidos que sean los gastos. No es lo mas not able en este asunto que gasten en minas de crédito, que prometen esperanzas, 
sino que lo hagan en las que despues de haber sido la destruccion de otros, estaban abandonadas, y en el embeleso que tienen de ocuparse en buscarlas; haciendo varias aberturas en los cerros, movidos para ello de ciertas señales exteriores que encuentran. y del concepto que forman de que debe haberlas con precision. Para el primer empeño siguen la opinion de que las riquezas son depósitos que Dios tiene reservados para los que los destina; y que aunque muchos hayan empobrecido buscándolos, no siendo para ellos para quien estaban, no se llegaba el término de que se hiciesen patentes. A lo segundo les mueve la disposicion y forma de la peñasquería del cerro, la direccion que lleva, la positura de las lajas, el ancho que tienen, la figura del cerro en su total. su magnitud, y aun hasta las yerbas que se crian. El concepto de estas señales se vigoriza con el juicio de los que tienen opinion de inteligentes, y sobre cada circunstancia forman un pronóstico, y exâgeran como infaliblé la mejor pintura de la riqueza que debe haber: para ello usan de un lenguage particular de minas, que tiene la virtud de apartar de la imaginacion todo otro asunto, y de recrear1a. Con estos preparativos el hombre mas apretado se hace generoso, el mas indiferente se dexa poseer de la persuasion, y creyendo de dia en dia, y de hora en hora que se cumple el instante de tener baxo su dominio la riqueza mayor, se entregan á su solicitud con tal empeño, que ni piensan, ni tratan, ni entienden de otra cosa, reduciendo todas sus conversaciones y negocios á este.

Io El incentivo de la plata llega hasta el término de que claudiquen los hombres de mas peso, madurez y juicio, sin que haya desengaños ni razones que los persuadan una vez que se empeían en ello. Todas sus conversaciones se reducen á tratur de los $\mathrm{Aa}^{\prime}$ asun- 
asuntos de las minas, de las dificultades vencidas, ó que faltan por vencer, de las señales que prometen sil abundancia, de los medios de su habilitacion, y de los exemplos de las grandes fortunas de los famosos mineros, y felices descubrimientos.

I No siempre, ni aun por lo comun, los que se ocupan en este exercicio son hombres de posibles y ricos: los mas de ellos son pobres sin recurso, y no pocos los que se pierden en la mercancía. Estos se agregan de compañía con algun cateador, y pasan á denunciar una de las minas que tienen reconocidas, ó á pedir la adjudicacion por compra al Rey. de alguna de las que se hallan despobladas, cuyo valor es de muy poca monta. Tambien suelen negociar cón el dueño de otra de las corrientes, que les ceda veta en ella: de qualesquiera de estos modos solicitan la posesion, y afianzan en la caxa Real, á donde toca dársela, pagar al Rey el diezmo de la plata que sacaren, y el importe del azogue que necesitaren para el beneficio. Este es el principio, y los débiles fundamentos que tienen los trabajos considerables de desentrañar cerros enteros para extraer la plata. Con la posesion no basta quando falta lo principal, que es el caudal que se ha de emplear en ello, y en esto es en lo que entra la industria, la persuasion, y el influxo que la riqueza tiene aun para vencer á los mas cautes y reservados.

r2 Con las muestras de los metales rìcos, que suponen ser de la suya, se dirigen á algun sugeto de caudal; y haciéndole manifestacion de ellas con gran misterio y mucha reserva, le hacen observar los filamentos de plata que la atraviesan: le ponderan la bondad de la veta, su grueso, con las demas señales que tiene favorables, dándole á entender ser de los pallacos que están fuera, y que solo con la diligencia de ponerla corriente se descubrirá el metal, su- 
DUODECIMO.

poniéndole, que de resulta de cierto derrumbo se abandonó; pero que sacados los escombros, y llesado á limpiarse, quedará clara: á esto añaden no sir necesario mucho caudal para conseguirlo; y formándole un plan de lo que hay que hacer, le van saboreando para que entre en el empeño, con una noticia muy prolixa de lo que se sacó en otro tienpo, ántes del accidente del derrumbo; reduciendo al fin el discurso á persuadir, que con un gasto moderado, como de 500 pesos, de 1000 , ó por este tenor de una cosa de poco momento, está facilitado todo. Para acabarlo de vencer, le ofrecen que será de su cuenta toda la piña que se saque, y que no se necesita del dinero en especie, sino en ropa, aguardiente, hierro, acero, y otros efectos que se distribuyen entre los trabajadores. Aunque á la primera diligencia no surta el efecto que se pretende, queda sembrada la semilla para que labre en el ánimo disponiéndolo á facilitar la primer cantidad.

13 Con este método hacen tentativas er distintos sugetos, procurando que no sepan unos de otros, para lo qual tienen la facilidad de elegirlos en lugares distantes, como en Lima, y en Guamanga, ó el Cuzco, la Paz, Guancavelica, ú otra de las muchas ciudades y villas de aquellas partes. Con estas persuasivas no dexa de haber alguno que se anime mas que los otros, y no pocas veces sin dos, ó tres los concurrentes, que se ofrecen administrar para los gastos. Consumido el primer caudal, es forzoso ampliar nueva cantidad por no perder aquella, porque estos, que son los que llaman aviadores, no tienen de donde hacerse pago, hasta que la mina lo produzca. Los mineros, mirando siempre el fin de que los desembolsos sean ménos violentos, les presentan nuevas señales de irse logrando el intento; y aun suelen llevar á los aviadores algun piñoncillo de poAa 2.

$\cos$ 
188

ENTRETENIMIENTO

cos marcos que se lo confirme. De este modo se gastan cantidades de 50 ó 60000 pesos insensiblem ente, sin adelantamiento conocido.

I4 Estos granjes expendios, que no tienen mas límite que lo que duran los caudales, á ménos que la fortuna sea favorable, ofrecen dos cosas notables: la primera, que los dueños que los franquean queden tan sutis echos de haberlo hecho, que no conociendo la flaqueza en que han incurrido, no les resulte sentimiento contra quien les induxo; y que los que son escasos para otros gastos, no lo manifiesten en el de esta especie, de lo qual se ven muchos exemplares: lo otro, que corrido largo tiempo de estarse trabajando sin sacarse fruto de entidad, nunca falta en su inteligencia mas obra para encontrar la veta rica que la que se puede hacer en un dia, cuyo término, al parecer corto, no tiene fin, porque siempre sobreviene nueva dificultad que lo dilata otro tanto, y de este modo pasan muchos, y se cumplen años sin verse el éxito que tiene presente la imaginacion.

I5 Quando sucede que el trabajo se hace en mina antigua, que estubo abandonada, ó en veta de mina corriente, no dexa de sacarse alguna plata; pero es tan poca, que no tiene comparacion con lo que se gasta, y el marco sale por tres ó quatro tantos de su valor: al contrario, si despues de muchos afanes y expendios se logra la felicidad de dar con la riqueza, se recupera en breve tiempo lo consumido, $y$ quantos tienen parte en la mina se enriquecen, el aviador, el minero, y el cateador, que de ordinario es el capataz, y quien dirige los trabajos. Los buenos éxitos, que la casualidad proporciona á una parte de los que se dedican á este exercicio, animan á muchos á que permanezcan con constancia; pero siendo todo casualidad, es aun mas seguro el riesgo de perder que el de adelantar.

De 
I6 De esto proviene decirse comunmente entre los mineros ser ellos los que hacen un servicio distinguido al Rey, porque á no entrar con tanto cmfeño y facilidad en el trabajo de las minas, exponiendo caudales considerables, no se sacaria la plata, que constituye la riqueza de la Monarquía. En algun modo van fundados, porque en realidad sucede así; pero si se mira bien el fin que en ello llevan, no es enriquecer la Monarquía, sino hacerse ellos pederoses con la posesion de mucha plata, cuyo deseo es el que los enagena á los términos que se han explicado.

I7 De ordinario hay junto á las minas que han estado abandonadas, montones de escombros, siendo los que quedáron allí por inútiles quando se trabajaban: los que se dedican á ponerlas corrientes, hacen escoger en ellos aquellos pedazos de mineral que manifiestan buenas pintas, y los benefician, con cuya diligencia sacan alguna plata, y en ocasiones les dan mas que el mineral recientemente sacado. A estos pedazos llaman pallacos, y la diligencia de escogerlos pallaquear: de esto ha nacido la opinion, de que la plata se cria con el tiempo, y que la piedra, ó tierras de la veta son el vehículo en donde se fixan las semillas, que preparadas con las varias materias que contiene, se va perfeccionando y creciendo: para ello suponen, que quando los abandonáron fué por no contener parte alguna de plata, pues á no ser así no los hubieran despreciado. Este dictámen pudiera tener la réplica de que en el tiempo que los abandonáron, los miraban de poco provecho, respecto de la mayor ley que tenia el mineral que beneficiaban; pero es tan comun hallarse plata en razonable cantidad en los pallacos antiguos, que no está totalmente desnuda de fundamento la idea, hallándose apoyada del exemplar de suceder 10. mis- 
sinismo en las minas de azogue, y de experimentarse dentro de las mismas veras que las que se abandonaron, por no sacar de ellas plata alguna, vueltas á trabajar despues de 60 ó mas años; la dan, y tal vez con regular abundancia.

Is Corrobora lo antecedente el que en tanto que la mina mantiene señales de plata, y que no falta dinero para sus gastos, no se abandona, subsistiendo la esperanza de encontrar la riqueza que se solicita; y así quando estaba abundante no era regular hacerlo, y quando escasea se aprovecha todo, con la consideracion de que aunque sea poco lo que rinda, siempre ayuda; con que no puede suponerse como cierto que los pallacos tuviesen plata al tiempo que se extraxéron de la mina, y que se desperdiciasen por haber otros que rendian mas.

I9 Quando se trabaja en vetas que no han declarado la plata, ó quando la que rinden es poca, se procura pallaquear, si se encuentran escombros en que hacerlo; y fuera de lo que contribuyen para los gastos, sirven los piñones, y las piedras sobresalientes que se encuentran para sostener el concepto con los aviadores á quienes las presentan, en apoyo de las noticias que les dan sobre los progresos que se van haciendo, y así mantienen las esperanzas de que irá siempre en aumento: con estos convencimientos abren la mano, y franquean caudal para llevar la obra á su perfeccion.

20 No hay satisfaccion que iguale á la de un aviador, ó dueño de mina, que la hace trabajar por medio de administrador, quando le presentan algun piñon ó piña por premio de sus expendios, entregándole una ó varias piedras donde se dexa ver la señal de la plata en algun filamento. El gusto que en ello reciben hace olvidar la memoria de quanto ha costado, que suele ser por cada marco uno ó varios 
DUODECIMO.

I9I

rios miles de pesos. Esta complacencia, adquirida á tanta costa, dexa descansado el ánimo, no solo por la esperanza que confirma del logro total, sino por la circunstancia de ver el parto de la tierra en el metal precioso, cuyas señales, como principio del triunfo, las ponen con cuidado en el principal lugar de la casa, donde esté patente á todos, y á quantos concurren se las muestran, para que ayuden á la celebridad y á los plácemes: enténces se repiten las relaciones que el minero ó el capataz han hecho, sin faltar señal alguna; y se embelesa la imaginacion, prometiéndose ver multiplicadas las piñas, á correspondencia de los deseos.

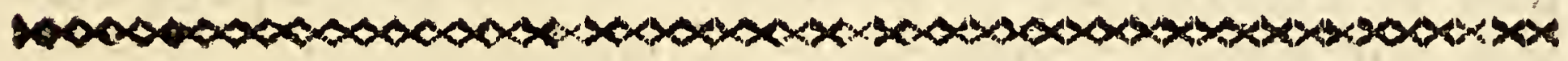

\section{ENTRETENIMIENTO XIII.}

Continua el asunto de los minerales, y se explica quales son las principales caxas, y lo que se funde de plata en ellas.

$\mathbb{E}_{\mathrm{n}}$ el anterior Entretenimiento se ha dado noticia de las débiles fundamentos con que se da principio al trabajo de las minas, y que emprendidas muchas de ellas por hombres que no tienen caudal alguno, aun para la-propia subsistencia, se gastan por sus manos crecidos miles en solicitud de la plata. En este se seguirá dando la de los minerales, y del modo con que se manejan en ellos, por no ser esta de ménos industria y habilidad, que el conseguir fondos con la vana idea de multiplicárlos en las cosechas abundantes de piña, que se proponen sacar de ellas: para esto es preciso dar idea del modo con que se ministra el azogue, por ser 
el principal agente, que facilita el laboréo de las minas.

2 El azogue es la medida de la plata, ó el mas seguro testigo de lo que se extrae de las minas, porque beneficiandose generalmente por el método de la amalgama, no puede separarse del mineral sin el auxilio de este metal. Hay no obstante algunas minas que se trabajan por el fuego, pero son pocas, $y$ ademas concurre el inconveniente de no haber con abundancia la leña en donde están, ni el icho, que es un equivalente para suplirse: por esta razon, aunque algunos minerales podrian rendir mas por este segundo método que por el primero, no es practicable. Sentado pués que la mayor parte se hace por medio del azogue, conocido el consumo de este, puede averiguarse, con alguna corta diferencia, lo que se sasa de aquellas.

3 Es opinion corriente por allá, y muy comprobada, que las principales minas de crédito en lo antiguo han ido en descaecimiento; allí lo han sido las de Potosí, y en realidad no rinden al presente, ni á mucha distancia con la abundancia que en otros tiempos; esto procede de dos causas, la una de hallarse en tal profundidad parte de sus vetas, que el costo de desaguarlas, con el de las obras que necesitan para que se mantengan, y el de atraer los metales, son mayores que las utilidades que rinden: la otra, porque á fucrza de haber sacado lo mas pingüe de ellas por largos años, han descaecido; y aunque esto no suceda en todas, se experimenta en las mas, considerándolas por lo que va corrido de este siglo: parece que al paso que unas van en decadencia, se descubren vetas algo sobresalientes en otras, resultando que en el total de aquel dilatado pais no se extrae ménos plata al presente de la que se sacaba ahora 70 ú 80 años,

con 
con la diferencia de haber mudado de lugar.

4 El cerro de Potosí debe considerarse ccmo un panal de abejas en las innumerables bocas que ticne, $y$ en las concavidades y minas que hay en su interior, y así lo da á entender la monstruosa cantidad de material que se ha sacado de sus entrañas, para lagrar la parte de mineral, que al modo de venas se halla repartido en él, siendo de este del que se saca despues la plata; y así, si fuese dable registrarlo de una vez, quitada la capa exterior, se descubriria un sin fin de caminos y calles subterráneas, conducidas sin regularidad en las direcciones, segun la disposicion en que van las vetas. Aquellos minerales, que en el lenguage conun llaman metales, despues de los primitivos tiempos inmediatos al descubrimiento, en que fuéron muy ricos, quedáron de poca ley; siendo tal, que si no tuvieran la ventaja de ser dóciles para extraerse, y para el beneficio, no se podrian aprovechar; pero con esta circunstancia viene á ser la docilidad compensativo de la falta de riqueza. Otros minerales hay en distintas partes, que siendo de mas plata son ménos proporcionados para el trabajo por la dureza, por los gastos que de ella se siguen, ó por la mezcla de antimonios y de otras varias materias, que no dan lugar á que se pongan en punto de que el azogue obre en ellos. Aun con estos inconvenientes es tal el atractivo de unos y de otros, que no falta quien se dedique á probar suerte, sin reparar en la baxa ley, en la dureza, ó en la dificultad de acertar con el método del beneficio que requieren.

5 Hállanse repartidas las minas de plata en varias Provincias, y parece que en esto guardó la naturaleza un órden correspondiente al de los animales y, plantas, no haciéndolas comunes á todos los paises, aun del mismo continente, como lo acredita el que siendo Punas de quasi igual altura y frialdad las que $\mathrm{Bb}$

cor - 
corren desde la parte del Norte de Lima hasta el paralelo de Potosí, y de allí hasta Chile, es en el ámbito que hay desde el de Lima al de Potosí donde abundan; y en los que corren desde el mismo paralelo de Lima hácia la Equinocial van siendo ménos, como lo confirman las pocas que se conocen en el reyno de Quito, y de alli hácia la parte de Santa Fe, en cuyo ámbito son mas regulares las de oro, bien que estas están en lus climas calientes, siendo muy raro que las haya fuera de ellos. Lo mismo sucede desde Potosí hácia el Sur, en cuya larga extension por gran casualidad se sabe de alguna. La fisica mas sutíl no facilita reglas seguras para explicar de un género que satisfaga este raro fenómeno, mediante que al parecer concurren unas mismas circunstancias en todos ellos,

6 Habiéndose de beneficiar los minerales de plata por medio del azogue, tomó el Estado á su cargo el cuidado de ministrarlo, para que este principal ingrediente, sin el qual no podian ser ítiles aquellos, no estuviese expuesto á contingencias, y que sin embarazo pudiesen dedicarse los mineros á las labores, con seguridad de tenerlo siempre que lo necesiten. $A$ este fin se estableciéron varias caxas en aquellos parages donde habia mas abundancia de minerales, siendo estas otros tantos depósitos de él, y por conseqüiencia los lugares determinados á donde debe llevarse á fundir lo que se saca de plata, para satisfacer al Rey el derecho del diezmo y el valor de los azogues que se franquea á cada individuo en el discurso del año.

7 Entre estos depósitos, ó caxas Reales, se halla una principal, que ministra á todas las otras el azogue, y es la de Guancavelica, siguiéndose luego, por la parte del Norte, Xauja, Pasco, Lima y Truxillo: por la del Sur el Cuzco, Chucuito, la Paz, Cayllo- 
ma, Carangas, Oruro y Potosí; de suerte que en todas vienen á ser doce; pero no en los distritos de todas hay abundancia de minerales, pues en algunas son tan escasos, que apénas hay indicios de ellos. De estos depósitos sacan sus provisiones los mineros que están en cada jurisdiccion, y se les subministran fiados por término de un año, para facilitarles que puedan trabajar, sin hacer de pronto desembolso, por ser uno de los mayores costos que tienen. El método que se sigue en esto es acudir los mineros á la caxa Real, y afianzar el azogue que necesitan para el uso de los metales que deben sacar de la mina en el discurso del año, con obligacion de tenerlo pagado al tiempo de cumplirse. Este año se cuenta empezando por un antiguo uso, el primer dia de Mayo, y finalizase el último de Abril del siguiente. Obsérvase así no solo en lo perteneciente al azogue, sino en todos los ramos de la Real Hacienda, orque en aquel dia deben concluir todas las cuentas de las caxas Reales, y empezar otras nuevas, que llaman cerrar las CartasCuentas.

8 Es de mucho alivio, como se dexa comprehender, para los mineros la proporcion de tener el azogue, sin hacer de pronto el desembolso de su valor, usando de este caudal por el discurso de un año; y con la misma plata que les facilita, lo pagan; pero aun todavía no basta para que se sostengan, acaeciendo con bastante freqüencia hallarse, sin cumplirse el año, sin fondos para salir de este empeño, que es conseqüente, ó á la poca ley que tiene el metal, ó á los gastos que se les aumentan, bien sea por su dureza y dificultades que hay para sacarlo, ó por las obras y trabajos que necesitan hacer dentro de la mina. De aqui se origina que se abandonan aquellas que no sufragan para sostenerse quando los dueños no poseen caudal propio, ó tienen aviadores que se lo Bb2 sub- 
subministren. Las minas se deben considerar como un juego de fortuna, que para el que está favorable le enrifuecen, y por el contrario destruyen y aniquilan al que les es contraria.

9 El que dexa de corresponder á la paga del azogue de un año, no puede prometerse tenerlo en lo sucesiro; y careciendo de este principal agente, se inutiliza la mina y se abandona, volviendo á ponerse en aquel primer estado en que la halló el que emprendió su trabajo: se hacen derrumbos considerables; las aguas se aumentan aunque fuesen pocas; se ciegan las calles; y al cabo de tiempo, quando otro la emprende de nuevo, tiene que hacer el mismo trabajo que el antecesor con mucho gasto.

Io Al ver las considerables porciones de plata que se conducen todos los años de las Indias á España, no es facil de concebir la dificultad que cuesta de conseguirla en su propio orígen, y que se logra á expensas de muchos caudales, $y$ de la infatigable pasion de los que se dedican á este exercicio, que es la que los empeña, segun se dixo en el Entretenimiento anterior, para no abandonarla, ínterin que se les proporciona el modo de tener azogue, aunque sea muy poca la plata que saquen de ella; y así esta providencia es uno de los mayores auxillios que tienen para promover su trabajo.

I I $\operatorname{Sin}$ duda fué fundada en este conocimiento la disposicion en aquellos reynos de franquear el azogue al costo que tiene; contribuyendo tambien la circunstancia de ser bastante crecido, respecto del regular en España; por cuya regla no es igual en todas partes, proporcionándose á las distancias; y así en Guancavelica es á 79 pesos $\frac{37 \frac{\pi}{2}}{100}$; en Xauja á $85 \frac{6 \frac{\mathrm{r}}{4}}{100}$; en Pasco á $84 \frac{7 \frac{\pi}{2}}{100}$; en Lima á $84 \frac{7 \frac{\pi}{2}}{100}$; cn Truxillo se les carga 
el mas costo que tiene su conduccion desde Lima allá; en el Cuzcóa $95 \frac{87 \frac{1}{2}}{100}$; en Caylloma á $86 \frac{69}{100}$; en Carangas á $94 \frac{50}{100}$; en Oruro á $97 \frac{10 \frac{\pi}{2}}{100}$; en Potosí á $99 \frac{12 \frac{\pi}{2}}{100}$; siendo del cargo de los mineros la conduccion despues desde las caxas hasta los asientos de las minas.

I2 El Erario gozaba los dos derechos que le correspondian en el quinto del azogue que se sacaba, y. en el de la plata: este último se rebaxó al décimo en el año de 1737 , en fuerza de reiteradas representaciones que hiciéron los mineros, y de sérias justificaciones: por donde se averiguó, que la situacion de ellas no permitia tanta contribucion; pues por no sufragar á ello, se abandonaban muchas, y el Estado padecia el detrimento de su pérdida. Con iguales fundados motivos se libertó á los mineros, en el año de 6I, de la contribucion del quinto del azogue for tiempo de dos años, reservando á la voluntad de S. M. , y á lo que la experiencia enseñase, el dexarlo así para lo sucesivo, ó que espirados volviesen á contribuir; pero parece que hasta el presente va corriendo en la misma forma; que es convincente prueba del descaecimiento de su respectiva mina; y que mirado este asunto, como el mas importante para la subsistencia de las de plata, se ha tenido por ménos inconveniente perder la Real Hacienda aquel ingreso, que mantenerle con el menoscabo de que se arruinasen las otras; con que la única utilidad que ha quedado á su beneficio es el diezmo de la plata que se saca, bien que sin disfrutarlo integramente.

I 3 Las minas en su generalidad subsisten en regular estado ínterin que se trabaja en ellas, porque á medida que se adelantan en lo largo y profundidad, se tiene cuidado de irlas asegurando con empotrados, dexando ademas los correspondientes estrivos de dis- 
tancia en distancia para la forraleza, á cuyo fin hay Ordenanzas y Leyes que lo previenen; pero quando les sobrevienen aguas en cantidad, y que no hay arbitrio para hacerles socavones por donde desagüen, es preciso abandonarlas, aunque se hallen en el término de la abundancia de la plata. El trabajo que se practica en ellas es continuo, haciéndose tanto de noche como de dia, y lo mismo el beneficio de metales en todas sus funciones, pues por una parte se muelen los que se sacan, hasta convertirlos en polvo muy menudo, y por otra se preparan los cuerpos para la amalgama, y se lavan los que tienen disposicion para ello. De esto resulta ser preciso que el azogue esté pronto, sin lo qual experimentarian grandes pérdidas los mineros; y una de las mas considerables sería el hallarse precisados á suspender las manipulaciones. Por esto es necesario mirarlas como un encadenamiento en donde los eslabones están enlazados el uno al otro, siendo el principal el azogue, sin el qual quedan divididos los demas.

I4 A proporcion que los metales son mas ricos, necesitan de mas azogue para la amalgama; y al respecto que la mina es mas opulenta de metales, por estar sus vetas mas pujantes, se saca mayor porcion de ellos, que es lo que los dueños apetecen, pues aunque la ganancia sea corta, la hace crecida la abundancia: por esta razon, los consumos del azogue no pueden ser iguales, ni tener regla la distribucion; pero cada uno sabe á corta diferencía, segun las vetas que trabaja, su grosor y riqueza, lo que puede necesitar para darles el último beneficio en el discurso del año, y procura proveerse de él con anticipacion.

I5 Por las cantidades de azogue expendidas en el discurso de varios años, en once de las caxas que se han nombrado, $y$. son las principales, no incluyendo 
DECIMOTERCIO.

la de Lima, se podrá venir en conocimiento del estado presente de los minerales de plata de aquel reyno; y para la mejor claridad se pondrá por su órden:

\begin{tabular}{|c|c|c|c|c|c|}
\hline CAXAS. & $\begin{array}{l}\text { Año de I7 } 59 . \\
\text { Qs. lib. onz. }\end{array}$ & $\begin{array}{c}\text { de } 1760 . \\
\text { Qs. lib. onz. }\end{array}$ & $\begin{array}{l}\text { de } 176 \text { I. } \\
\text { Qs. lib. onz }\end{array}$ & $\begin{array}{l}\text { de I }{ }^{62} \text {. } \\
\text { Qs. lib. ouz. }\end{array}$ & $\begin{array}{l}\text { de } 176_{3} . \\
\text { Qs. lib. onz. }\end{array}$ \\
\hline $\begin{array}{l}\text { Guancavelica. } \\
\text { Xauja........ } \\
\text { Pasco....... } \\
\text { Truxillo..... } \\
\text { Cuxco....... } \\
\text { Cbucuito..... } \\
\text { La Paz...... } \\
\text { Caylloma.... } \\
\text { Carangas.... } \\
\text { Oruro....... } \\
\text { Potosi...... }\end{array}$ & 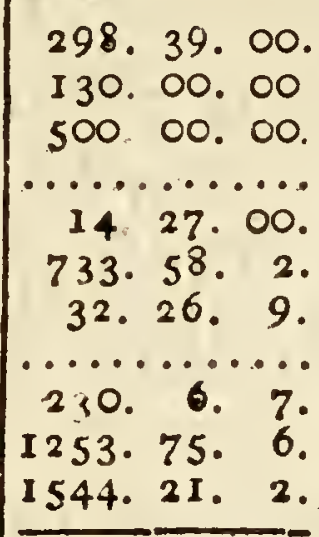 & $\begin{array}{rrr}242 . & 00 . & 00 . \\
140 . & 00 . & 00 \\
650 . & 00 . & 00 \\
\ldots \ldots \ldots & \ldots . & \ldots \\
5 . & 88 . & 00 . \\
740 . & 00 . & 00 . \\
64 . & 36 . & 4 . \\
396 . & 00 . & 00 . \\
191 . & 27 . & 00 . \\
1251 . & 60 . & 11 . \\
1694 . & 9 . & 2 \\
\end{array}$ & 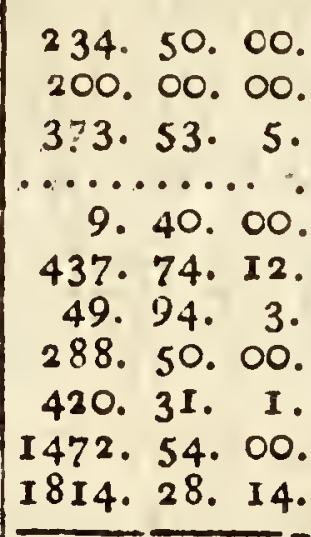 & 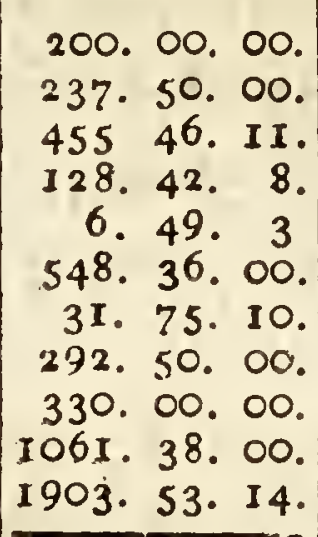 & $\begin{array}{rrr}142 . & 18 . & 8 . \\
247 . & 42 & 00 \\
729 . & 00 . & 00 \\
131 . & 17 . & 00 \\
13 . & 50 . & 8 . \\
369 . & 34 . & 4 . \\
30 . & 25 . & 10 . \\
374 . & 59 . & 8 . \\
150 . & 4 . & 1 . \\
1264 . & 63 . & 10 . \\
1792 . & 86 . & 12 .\end{array}$ \\
\hline Sumas. & 4727 . 5I. IO. & $5375.2 \mathrm{I} . \quad$ I. & 5295.76 .3 & 5195.41 .14 & 5245 \\
\hline
\end{tabular}

I6 El consumo del primero de estos cinco años está incompleto, faltando lo correspondiente á las caxas de Truxillo y de Caylloma: en el segundo y tercero falta el de la primera; y aumentándolo de 10 correspondiente por el de los años de 62 y 63 , vendrán á completarse, y serán el año de 59,5155 quintales, 94 libras y 2 onzas : el de 1760,5503 quintales, 63 libras y. 9 onzas; y el de 1761,5424 quintales, 18 libras y 8 onzas: en esta forma, tomando un medio entre todos cinco, es 5304 quintales y 84 libras.

I 7 Son varias las opiniones sobre la cantidad del consumo que se experimenta en el azogue que se emplea en la amalgama de la plata: unos lo fixan á I4 onzas por marco, otros á I $2, y$ otros lo ponen en algo ménos; pero generalmente convienen en que el preciso y verdadero consumo es el equivalente al peso de la plata que se saca; por cuya regla, el marco de esta debe consumir media libra de azogue, yá todo el exceso llaman pérdida. Hay metales, segun la opinion de los mineros, que por su calidad consume mas que otros, y de estos dicen tener mas pérdida, 
contándola en lo que excede al peso de la plata; y así la mina que necesita para cada marco I 3 onzas de azogue, sin volver á recogerse, tiene de perdida 5 onzas; la que necesita I 4 onzas, 6 ; y por este término, otros metales hay que pierden ménos, pero no se conoce alguno que poca ó mucha no la tenga. Sin hacer cuentas imaginarias puede terminarse el consumo y pérdida del total de las minas, unas con otras, por I 2 onzas el marco, y en esto convienen los mas; en cuyo caso, los 5304 quintales y 84 libras que se gastan en el año, deben producir 707,312 marcos de plata de piña, que son $5.658,496$ onzas de la misma plata. A esta cantidad debe aumentársele lo que corresponde al ménos azogue que las i 2 onzas por marco de consumo, y la que se saca por fundicion, cuyos dos puntos son inaveriguables; no siendo fácil conseguir que con ingenuidad digan los mineros en lo que consiste su verdadero consumo y pérdida.

I 8 Es misterio tan reservado la noticia fixa de la cantidad de marcos de plata que cada minero saca del azogue que consume, que la mas eficaz diligencia no es suficiente para conseguirla; pero averiguado esto del mayor número de las caxas podrá formarse el cómputo de la plata que sacáron, y la que faltó para completar la que correspondia al azogue que consumiéron.

I9 El año de ${ }^{7} \sigma_{3}$ la caxa de Guancavelica dió por consumidas 13,448 libras de azogue ménos que lo expendido: fundió i 8,02 I marcos, por los quales contribuyó por el Real derecho de diezmos y cobos 17,743 pesos y 3 reales. Segun la regla de las 12 onzas, debia haber fundido solo $17,93^{\circ} \frac{\mathrm{K}}{2}$, y así tuvo de aumento $90 \frac{\mathrm{r}}{2}$ marcos, que no son de consideracion en el todo de la cantidad. Será reparable que los consumos de azogue para esta cuenta de marcos, no son iguales á los gastos de él en el año; y esto procede unas 
veces de no fundir todos los mineros la piña que sacan en el corriente del mismo año que recibićron el azogue, y otras de aumentarse las fundiciones con los que dexáron de hacerlas en el año antecedente.

20 La de Xauja consumió 26,742 libras mas que lo expendido: fundió 14,565 marcos, por lo que solo contribuyó de derechos 14,340 pesos y 3 reales: debia haber fundido 35,656 marcos, y haber contribuido 35,105 pesos y $4^{\frac{1}{2}}$ reales; con que le faltáron. para la cuenta 2 I,og I marco, y dexó de contribuir 20,765 pesos.

2 I La de Chucuito consumió 42,962 libras; fundió 48,063 marcos y 3 onzas; pagáron 47,322 pesos y 3 reales: su fundicion de plata debió haber sido de $57,282 \frac{2}{3}$; le faltáron 9219 y 3 onzas, por los quales dexó de contribuir 9065 pesos y 3 reales.

22 La de la Paz tuvo de consumo de azogue 3025 libras; fundió 1601 marcos, por los quales contribuyó I57I pesos y 5 reales: deberia haber fundido $4034 \frac{2}{3}$ marcos : vino á ser diminuta la fundicion de $243^{2} \frac{5}{8}$ marcos, á los quales corresponden 2395 pesos y 2 reales, que dexáron de contribuirse.

23 La caxa de Caylloma consumió 49,059 libras de azogue : se fundiéron $28,029 \frac{1}{2}$ marcos, cuya contribucion de derechos fué 27,596 pesos y $7 \frac{3}{4}$ reales; pero la fundicion debia haber sido de 65,412 marcos, y hubo de ménos $37,382 \frac{3}{4}$ marcos; y el importe de los derechos disminuyó de 36,805 pesos $y$ $5 \frac{3}{4}$ reales.

24 La de Carangas consumió 15,004 $\frac{x}{16}$ libras: fundió 22,304 marcos y una onza; por los quales contribuyó de derechos 22,076 pesos: su fundicion excedió, al respecto de las 12 onzas, en 2299 marcos y una onza.

25 La caxa de Oruro consumió I $25,463 \frac{2}{3}$ libras Cc 
202

ENTRETENIMIENTO

de azogue: su fundicion fué de $\mathrm{I} 2 \mathrm{I}, 856$ marcos y 4 onzas, por los que contribuyó I I 9,975 pesos y $7 \frac{1}{2}$ reales; pero segun el azogue consumido debió haberse extendido la fundicion á 167,284 marcos, mayor que la que se hizo de $45,427^{\frac{1}{2}}$ marcos, cuyos derechos corresponden ser 44,726 pesos y $7^{\frac{1}{2}}$ reales.

26 En las cinco caxas que quedan nombradas hubo de ménos en fundicion de marcos $y$ de derechos Reales, como se sigue:

\begin{tabular}{|c|c|c|}
\hline AS. & $\begin{array}{l}\text { Falta en la fun- } \\
\text { dicion. }\end{array}$ & $\left.\right|_{\text {Disminucion de derec }} ^{\text {Reales. }}$ \\
\hline $\begin{array}{l}\text { La de Xav } \\
\text { La de Cbi } \\
\text { La de la } \\
\text { La de Cay } \\
\text { La de Oru }\end{array}$ & $\begin{array}{l}\text { 2I. O9I. marco. } \\
9.219 . \\
2.432 . \frac{5}{8} \\
37.382 \cdot \frac{3}{4} \\
45.427 \cdot \frac{1}{2}\end{array}$ & $\begin{array}{r}20.765 \cdot 2 . \\
9.065 \cdot 3 \cdot \\
2.392 .5 \cdot \\
36.805 \cdot 5 \cdot \frac{3}{4} \\
44 \cdot 726.7 \cdot \frac{1}{2}\end{array}$ \\
\hline & 15.552 .7 & I 3 \\
\hline
\end{tabular}

27 El importe de los derechos que el Rey sacó de las minas de la pertenencia de las siete caxas que quedan nombradas, fué:

De las de Guancavelica... 17. 743. 3.

De las de Xauja............ I4. 340. 3 .

De las de Chucuito.......... 47. 322. 3 .

De las de la Paz........... I. 57I. 5 .

De las de Caylloma........ 27. 596. 7.3.

De las de Carangas........ 22. 076.

De las de Oruro.............. I 1 9. 975. 7.x

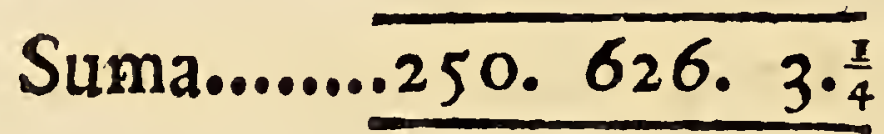

28 De modo que de las siete caxas recibe la Real Hacienda la quarta parte de un millon de pesos, á corta diferencia, y dexa de percibir mas de la décima parte del millon. 
DECIMOTERCIO.

29 Las quatro caxas restantes son Pasco, en la Provincia de Tarma, que es de consideracion: la del Cuzco, que no funde plata: la de Truxillo, que es mediana; y la de Potosí, que es la mayor, pues excede á la de Oruro en 54000 libras de azogue de consumo; y haciendo un juicio prudente no llegara á medio millon todo lo que reditúan á $S$. M. en cada año las minas del Perú, que usan de él.

30 La cantidad de marcos que dexan de fundirse en sus respectivas caxas, respecto del azogue que se les ministra, y la mas porcion que benefician quando el consumo y pérdida no llega á las 12 onzas por marco, no ménos que toda la que se saca por fuego, tiene tres destinos:-una parte se extravia, otra se funde para convertirla en vaxilla, y otra pasa á fundirse á la caxa de Lima por especial gracia que se les concede; pero rigorosamente deberia llevarse á la caxa que ministra los azogues, que es la del distrito, así por ser la mas inmediata, como para satisfacer los derechos con ella, y hacer constar haberse hecho el uso que corresponde con el que se les ha ministrado. 
204

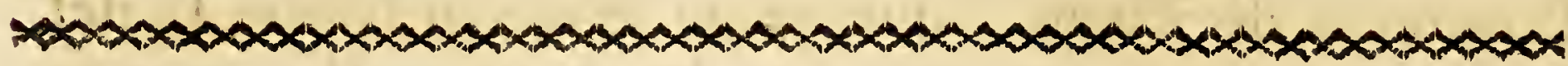

\section{ENTRETENIMIENTO XIV.}

Sobre el estado actual de las minas, $y$ las que se benefician por el fuego ó por el azogue.

I La jurisdiccion del Cuzco es límítada; en su distrito no hay minas, y por esto allí no se funde plata: el poco azogue que se consume es para las manufacturas, de las quales hay bastantes en aquella ciudad, siendo sus vecinos industriosos en obras de mano.

2 En los tiempos pasados fué rica la Provincia de Castro-Virreyna por las muchas y sobresalientes minas de plata que se trabajaban en ella, de modo que tenia fama en esta parte; pero ha venido á tal decadencia, que es al presente de las mas pobres, y solo se trabaja escàsamente en una, ú otra por sugetos de pocos arbitrios, que lo mas que hacen es pallaquear, y hacer las cortas fundiciones que les permite este arbitrio: es dependiente de la caxa de Guancavelica.

3 La de Vilcas-Guaman tiene algunas minas, aunque solo se trabaja en una con buenas muestras de dar riqueza: en la de Guanta se sacaba plata de otra; pero esta habia arruinado al que la tenia por su cuenta, gastando en ella un caudal bastante crecido, en cuya correspondencia le daba algunos marcos de piTa de tiempo en tiempo, lo suficiente para mantener las esperanzas, mas no para poder enteramente costearse.

4 En la de Angaraez hay algunas que están abando- 
$D E C I$ IIOQ QUARTO.

donadas; una de ellas, de mejor señal que 205 la tomó á su cargo un sugeto de conocido otras, que lo consumió en ella, contentándose con sacar algunos piñones de poco valor, $y$ algunas piedras de plata blanca, que tambien llaman machacado, cuyas muestras servian de embeleso al amo, y de dar por bien empleado el caudal que consumia en los trabajos emprendidos hasta conseguirlas, porque con estos indicios se prometia lograr la riqueza grande que suponia en la plata.

5 Quasi todo el azogue que se expende por la caxa de Guancavelica va á la Provincia de Sara Juan de Lucanas, que es donde hay algunas minas de consideracion, y particularmente una que tuvo bastante crédito; pero como en ellas son regulares las altas y baxas, descaeció en términos de no sufragar á sus costos: no obstante, con la fama que tenia por la riqueza que habia dado, se continuaba su trabajo con constancia, esperanzados que la veta volviese á su primer estado de mayor abundancia.

6 La caxa de Pasco se halla en lá jurisdiccion de la Provincia de Tarma, y no está en la principal poblacion, por haberla situado en la inmediacion á las minas para la mejor proporcion de proveerse de azogues, y de conducir las piñas que se deben fundir. De algunos años á esta parte han tomado incremento, prometiendo que se hará allí uno de los minerales pingües del reyno: son varias las minas que se trabajan con utilidad conocida, acreditándolo así el consumo del azogue, que un año con otro sale por 500 quintales á corta diferencia.

7 Las del distrito de Chucuito se mantienen en regular estado en lo presente; y aunque en el consumo de azogue se repara que en los dos primeros áños de la comparacion subia á $733^{\frac{1}{2}}$ y 740 quin- 
tales, y en los tres siguientes sale uno con otro á 450 con la disminucion de cerca de 300 ; no procede esto de haber descaecido en el término de estos cortos años; la flaquezá de sus minas viene de tiempos mas distantes, originada ó de la mucha profundidad que tienen unas, ó de los impedimentos que se encuentran en otras, para llegar á sacar el metal de buena ley.

8 De las caxas de Trúxillo se proveen aquellas minas que hay en la serranía que corre desde donde terminan las jurisdicciones de las de Xauja y Tarma hácia el Norte, yendo al reyno de Quito, en donde están las de Caxamarca, Chachapoyas, con otras: por el consumo que tiene anualmente se comprehende su cortedad, proveyendo desde allí quantas hay en un espacio de mas de 200 leguas, hasta los términos de las caxas de Piura y Cuenca, á donde no se hacen remisiones de azogue.

9 Reconócese que la caxa de Carangas fundió 2299 marcos de plata mas de lo que correspondia al azogue que expendió; y parecerá por este aumento haber habido en los minerales de su distrito ménos pérdida que en los de las otras caxas; pero no sucede así, y tal vez será mayor en ellas, de que hay bastantes indicios. En la pertenencia de aquella caxa se hallan las famosas minas de Huantajaya; y tanto en estas, como en el mayor número de las de su jurisdiccion, se benefician los metales por fundicion, sin necesitar de azogue; con que siendo el menor número y las de ménos riqueza las que gastan las $150,004 \frac{7}{5}$ libras de aquel metal, deberia ser la fundicion de marcos mucho mas quantiosa, y no faltan pruebas que lo convenzan.

Io Entre los grandes descubrimientos de minerales de plata que se han hecho en el reyno del Perú, ha sido famosísimo el de Huantajaya en los tiem- 
DECI MOQUARTO.
pos modernos, porque en su riqueza fué tal, que quanto cogia el ancho de la veta era de plata maciza, que se cortaba á cincel, de modo que verdaderamente le decia el nombre de mina de plata, por estar visible este metal en quanto se descubria; y tuvo parages donde, formando nudos la veta, se sacaban pedazos muy gruesos de ella. Esta famosa mina ha tenido, como sucede con todas, sus variaciones; y aunque no ha seguido en la abundancia de riquezas con que empezó, se sostiene, y trabajaba sin descaecimiento, dando siempre buenas porciones de aquel precioso metal.

I I Confírmase con la situacion de esta mina la singularidad que la naturaleza guarda con los metales preciosos de colocarlos en la tierra tan resguardados, que no sea dable desentrañarlos sin mucha penalidad y costos; pues siendo tan abundante de ellos, son excesivos los gástos que se ocasionan. La maturaleza eligió para hacer aquel rico depósito de plata el pais mas solitario y mas estéril de quantos hay en aquellas partes, en un despoblado retirado de las playas del mar á alguna distancia, y en un terreno de arena muerta: entre cerros dificiles de transitar por lo pesado del piso, que es de la misma arena, tan desproveido de todo, que no produce cosa alguna; siendo necesario que hasta el agua que se ha de beber, por no haberla allí, ni en las inmediaciones, junto con los víveres para alimentarse racionales y animales, se conduzcan de afuera en embarcaciones, y que puesto en tierra vuelva á transportarse por aquel pais dificil, hasta el sitio donde está la mina. A este respecto es costosísimo el beneficio de los metales, porque igualmente carece de leña aun para preparar el mantenimiento, siendo forzoso llevarla de lejos. Alli se reparte todo por racion del mismo modo que se ha- 
ce en las navegaciones largas; y aseguran los que han estado ser tan escaso, que en ocasiones cuesta una botella regular de agua un peso. Se han practicado muchos pozos, se ha reconocido el pais, y nï en los unos se ha encontrado agua, ni en las exploraciones se han visto indicios de algun manantial é arroyo, no ménos que de plantas, de donde pudiese sacarse leña para los grandes consumos que se hacen en la subsistencia de la gente, y en el beneficio de los metales: hallándose este parage en la Provincia de Arica, y es el puerto mas inmediato que tiene para los embarcos y descarga de cosas el de Iquique.

I 2 De este modo la abundancia y riquezas de tan especiales vetas se consume en el propio costo de trabajarlas; y empleado en ella misma lo que da, no es mayor la ganancia de sus dueños que las de otros, cuyas minas, sin iguales inconvenientes, son de ley muy inferior, igualándose por este término la mas rica y abundante con la que no lo es, para que así se mantenga en equilibrio la estimacion de la plata por las penalidades que se superan para conseguirla, en unas partes de la escasez, y en otras de la dureza de la piedra en donde se halla incorporada, ó bien por la demasiada profundidad, por la abundancia de agua que las anega, por los metales extraños que están interpolados con ella, ó por las dificultades de los lugares donde están, como sucede con la de Huantajaya.

I3 En las minas de Potosí, famosas en lo antiguo, sucede lo contrario que en las antecedentes: su ley es tan baxa en los tiempos presentes, que no podrian aprovecharse, si las proporciones que ofrecen para el beneficio, no lo facilitasen; son dóciles para sacarse $\mathbf{y}$ molerse; no tienen mayor dificultad en las operaciones que deben practicarse con ellos hasta sacar la piña; logran la comodidad de 
la célebre Laguna, que á gran costo se dispuso en el espacio que forman entre varios cerros, donde se recogen las aguas llovedizas, que saliendo despues por un rio, sirven para los ingenios en que se muelen los metales, cuyos ahorros recompensan en mucha parte lo que les falta de plata. Aquel cerro ha dado en otros tiempos metales bien ricos, de donde procedió su gran fama: aun todavía subsisten en algunas vetas señales de su primitiva ríqueza; pero por lo general son de escasa ley los que se trabajaban. Fuera de las muchas vetas que tiene el ambito del cerro, hay otras distintas minas en las Provincias de sus contornos, que han tenido fama en lo antiguo, pero al presente las mas de ellas han descaecido á semejanza de las de aquel: estas se proveen de azogue de las mismas caxas, debiendo hacer en cllas la correspondiente fundicion de plata, y generalmente ha sido la parte mas abundante de ellas en todo el Perú.

14. Dudariase de la gran riqueza de aquel cerro en lo antiguo, si se hubiese de conjeturar por la de sus minas en el tiempo presente, y no tratasen de ella autores de toda fe; porque es tanta la distancia que hay de unos á otros, que no tienen comparacion, y á este simil sucede con las otras minas famosas de aquel reyno; pero para que se comprehenda esto, se hará una breve comparacion entre lo que se dice en el libro intitulado Pretensiones del Potosi, que imprimió el Procurador General de aquella villa D. Sebastian de Sandoval y Guzman en el año de 1634 , y lo que al presente manifiesta el consumo de azogues, de que se ha dado noticia.

I5 El descubrimiento de aquellas minas se hizo en el año de 1545 , tan reciente á la conquista, que solo habian pasado ig años de la entrada de los Españoles en aquellas partes, habiendo sido en el de I526; que es buena prueba de estar vírgenes los $\mathrm{Dd}$

cer- 
cerros, brotándose la plata por ellos con abundancia. En aquellos principios se beneficiaba por fundicion, siendo en tal grado la riqueza, que de cada quintal de metal se sacaba la mitad de plata, con cuyo atractivo se estableciéron mas de seis mil guairas, ú hornillos en donde se fundia. Esta abundancia no duró mucho, pues en el año de I57I, que habian pasado 26 , se hallaban bastante disminuidas; y no siendo suficiente el método de fundir para extraer la plata, se entabló el del azogue por Pedro Fernandez de Velasco, bien que no con la perfeccion que al presente se practíca, pues á medida que lós metales han ido descaeciendo de ley, se ha sutilizado el modo de aprovecharlos, y de sacar de ellos la mayor utilidad que pueden dar, trabajando mucho en descubrir el método de beneficio que necesita cada uno.

16 En aquel tiempo el quintal de metal daba, segun lo que queda dicho, 50 libras de plata, que son cien marcos, y venia á salir á marco de plata por libra de metal. En el presente, segun noticias muy seguras, la mina de aquel cerro, que da quatro marcos de plata por caxon de metal, es buena, y dexa competentes utilidades á su amo: se trabajan muchas que no llegan á esta ley; y las que dan de quatro marcos para arriba se consideran sobresalientes. El caxon de metal, en las minas de plata, es de 50 quintales, que en el pie de los 4 marcos corresponde á $2 \frac{x}{2}$ adarmes de plata por cada arroba de metal, y sale la proporcion como I á I 250 ; esto es, que de la cantidad de metal que en aquel principio se sacaban 1250 marcos, se saca ahorá solo uno. Esta disforme disminucion sería increible si no se hallase verificada por la autenticidad de la obra que queda cirada, y fué dispuesta para presentarla á S. M.; bien que no es la misma esta proporcion en la disminucion que han tenido los quintos. 
17 Desde el año de i545, que fué el descubrimiento de la mina, hasta el de 1564 , dió de quintos aquel cerro 76 millones de pesos ensayados de I $3 \frac{r}{2}$ reales de plata: corresponden en cada uno de los ig años á 4 millones de pesos.

I 8 Desde I 564 hasta 1585 dió 35 millones; corresponde á cada uno de los 2 I años $1.666,666_{\overline{3}}^{2}$ pesos ensayados.

I9 Desde 1585 hasta 1624 se pagáron de dercchos 52 millones; y habiendo sido 39 años, corresponde á cada uno $\mathrm{I} .333,333$ pesos ensayados $\mathrm{y} \frac{1}{4}$.

20 Desde 1624, hasta 1633, que fué el antecedente al en que escribió, se pagáron 6 millones; y habiendo corrido 9 años, corresponde á cada uno $666,666 \frac{2}{3}$ pésos ensayados.

2 I En el año de 1763 consumió Potosí en las minas de su cerro, y en las de las Provincias comarcanas $179,286 \frac{3}{4}$ libras de azogue: por la regla de las i 2 onzas de consumo en cada marco de plata corresponde haber sacado 239,049 marcos, á los quales pertenecen por $5^{\circ}$ y cobos, á corta diferencia , 426,463 pesos de á 8 reales; que reducidos á los ensayados de $I 3 \frac{1}{2}$ reales, son 252,719 , y viene á ser como I á $15 \frac{5}{6}$. La gran diferencia que hay en esta proporcion de lo que contribuye, á la que resulta de la ley del metal, nace de dos causas; la primera de hallarse comprehendidos en los marcos que se funden al presente, los que proceden de todas las otras minas que se proveen de azogue de aquella misma caxa; la segunda, de que la cortedad que la ley tiene al presente, obliga á sacar incomparablemente mayor número de caxones de metal que los que se sacaban quando este era abundante en plata; y así suple al presente en parte el mayor trabajo á lo que falta de ley. 
22 Esto se confirma con el cómputo de los que debiéron sacarse en cada uno de los 19 años primeros, y los que se sacan al presente: los 4 millones de pesos ensayados de quintos que contribuyéron al Rey aquellas minas anualmente en el tiempo primitivo, corresponden á 20 millones de los mismos pesos de total saca de plata, que hacen $33.750,000$ pesos de á 8 reales, ú onzas de plata; $y$ siendo la mitad de lo que se sacaba en metal, venian á ser $4.218,750$ libras de este, que componen 42, i $87 \frac{1}{2}$ quintales.

23 Al presente, suponiendo que la ley del metal sed, tomándola por un medio, á 4 marcos por caxon, para sacar los 239,049 marcos, se necesitan $59,762 \frac{1}{4}$ caxones, que hacen 2.988, 100 quintales, $y$ entónces se conseguia la misma plata con solo 2390 quintales de metal, en lo que se ve la gran diferencia que hay de aquellos tiempos á los presentes; y si á esto se junta la porcion de desmontes que se necesitan sicar ahora para lograr los $59,762 \mathrm{ca}-$ xones de metal, iria la cuenta incomparablemente mas larga: debiendo suponer, que este número de caxones se saca de todos los minerales de la jurisdiccion de aquella caxa, como ántes se dixo.

24 Desde el año de 1633 hasta el tiempo presente ha tenido de disminucion la plata que se saca de solo aquel cerro algo mas de las dos tercias partes, sucediendo esto en el discurso de I 30 años: á cuyo respecto, si continuase la misma disminucion, se inutilizarian aquellas minas en otro tanto tiempo, ó en ménos; y por esto es muy conveniente en aquellos paises el fomento de los nuevos descubrimientos, con lo qual se recompensa en el modo posible el descaecimiento que tienen las mas antiguas con las modernas.

35. La gran riqueza de las minas antiguas está con- 
DECIMOQUARTO.

confirmada en la cilcunstancia de sacar plata de ellas los Indios, porque estos no conocian otro beneficio que poner al fuego, en tiestos, el metal donde la plata estaba visible y abundante, y derritiéndose la recogian: con cuyo modo sencillo, solo la que estaba limpia de otros metales podia fundirse. De esto ha nacido conservar el nombre de cayana los hornos en donde se hace la fundicion de la piña; porque en la lengura de lns Incas slynifica tiescu. DC esta grande abundancia se participó en los tiempos primeros de la conquista; y aun en los presentes sucede, que las minas que por alguna rara inclinacion manifiestan los Indios á los Españoles, cuyas noticias conservan de sus antepasados, tienen la plata visible, siendo desde luego perceptible su riqueza.

26 El azogue que distribuye la caxa de la Paz es en corta cantidad, como queda visto : parte de él tiene su consumo en las minas de Larecaxa, Jaraca, y otras que hay en su jurisdiccion: estos van á quintar á las caxas de Lima, teniendo permiso del Virrey para hacerlo así. Las de plata que están corrientes no son mas, ni de la abundancia que tuviéron en los tiempos pasados.

27 Los minerales de Caylloma se sostienen con regularidad, sin ser de los mas abundantes; pero hay opinion de que mas bien han aumentado que disminuido. Entre todos los de aquellos dilatados reynos, son ahora los mas sobresalientes los de Oruro, á cuyo parage parece irse transfiriendo las riquezas que gozáron en lo pasado las minas del distrito de Potosí: por el consumo de azogue se ve 10 que va acercándose, pues un año con otro consumió quasi r 300 quintales; y se asegura por varios sugetos inteligentes y dignos de fe, que la ley de los metales, en la mayor parte de los minerales, cra buena respecto de las de otras minas, y que 
que se reconocia ir en aumento.

28 De la noticia que queda dada se concluye, que en el total de aquellos reynos no han disminuido sensiblemente las minas de plata de lo que fuéron en el principio de este siglo, ó en las cercanías de entrar en él; pues si en unas partes han ido á ménos, en otras se ha reconocido aumento, como sucede en Pasco, Oruro y Carangas, de que es prucla la regularidad cí sarisfacer el importe del azo gue los mineros: al contrario de aquellos que trabajan en vetas pobres, que quando llega el fin del año es forzoso proceder contra ellos y sus fiadores para hacer efectivo el entero en caxas, á que están obligados.

29 En el año de 60 solicitáron los vecinos de la Provincia del Tucumán que se les proveyese de azogue, por tener esperanzas de ciertas minas que empezaban á descubrirse, y por carecer de él no podian darles el beneficio necesario, ni averiguar lo que producirian; y siendo en aquellos reynos uno de los principales asuntos el fomento de las minas de oro y plata, obtuviéron 50 quintales, pero parece que no correspondiéron á lo que se pensaba; porque hasta el de 63 no habia muestras de cllo. Quasi lo mismo sucedió en el reyno de Chile, donde se creyó que se habian descubierto del mismo metal, y que prometian abundancia; pero las que allí se han hallado no son de la entidad y firmeza que las del Perú, y por lo comun consisten en mantos, que son superficiales, y llegadas á profundar pierden; no sucediendo lo mismo con las minas que van en vetas entre caxas formales; pues aunque hay muchas, que la mayor riqueza la tienen en la superficie, siempre conservan alguna parte en lo profundo, sucediendo en otras al contrario, que hasta llegar á las humedades no manifiestan toda su ley. 
3o La piña y los tejos de oro, quando no están quintados, llevando en los sellos que se les imprimen la marca, son contrabando en todo el Perú, y solo es permitido conducirlos via recta desde los minerales á las caxas á donde pertenecen, para fundirlos allí, y pagar al Rey los derechos que le pertenecen del diezmo y cobos; pero en aquellos paises dilatadísimos, donde las poblaciones están apartadas unas de otras, y que se anda por lo regular por los despoblados para buscar los pastos, hay facilidad de conducirlos extraviadamente, y por esto no se verifica fundirse en las caxas toda la que se saca de las minas.

3 I Los establecimientos de fundicion están en las caxas Reales donde hay depósito de azogues; y á estas fundiciones llaman cayana, como queda explicado. En estas oficinas se convierten en barras, y se van numerando desde uno en adelante, empezando con el año, y concluyendo con él: se les pone el año en que se han fundido, el peso que cada una tiene en marcos, onzas y adarmes, y la ley; á cuya noticia se agregan los sellos Reales: con esto quedan convertidas á una moneda del valor de 2 ó 3 mil pesos, y aun solian pasar. En esta forma se tragina á donde se quiere dentro del reyno, porque llevan los requisitos que manifiestan quantas circunstancias son precisas para la buena fe, y la de haber contribuido al Rey sus Reales derechos. Las barras ya selladas, y lo mismo los tejos, iban á parar despues á las Casas de Moneda de Lima: allí se volvian á exâminar de peso y de ley, para ver si habia equivocacion, ó descuido en la que se fundiéron, cuya diligencia se practica con presencia de los interesados, y se convierten en moneda. Las de Potosí no hacian este curso, porque en atencion á ser allí donde están las minas mas antiguas y acreditadas del rey-

no, 
no, hay establecimiento de Casa de Moneda: modernamente se han hecho en Santiago de Chile y Oruro para evitar la incomodidad de conducirlas hasta Lima.

32 La plata, como se ha visto, sale de las minas á expensas del trabajo de los mineros: corre desde ellas á las primeras caxas Reales, quando no se extravía, ó se convierte en vaxilla; y sigue despues á la Casa de Moneda. Convertida allí en pesos duros viene á España, para repartirse por todo el mundo, sin que le sirva el signo que lleva mas que para la primer venta, porque despues se admite, y es apetecida como materia sin respecto al signo.

33 No son siempre los mineros los que conducen de su cuenta las piñas á las caxas Reales para fundirlas y pagar los derechos. Esto solo se practica por los acaudalados que las trabajan sin empeñarse; pero los que no se hallan en este caso pagan con ella á los aviadores, que los fomentan, ó la dan á los rescatadores en pago de los efectos que les llevan á las minas para el consumo de los trabajadores, y para la habilitacion de los menesteres, siendo ellos los que las presentan en las caxas para que se fundan. Tambien entra en parte de la habilitacion el azogue, á cuyo fin los mismos aviadores y rescatadores lo solicitan, á fin de que no haya motivo de que cese el trabajo ni el beneficio, por ser esto en lo que tienen la utilidad. El negocio de ir á comprar piña á las minas llaman rescatar, y de ello toman nombre de rescatadores los que llevan cosas que vender.

34 Los mineros acomodados, siendo así que és de la mina de donde consiguen las riquezas, no son continuos en ellas: unos van de tarde en tarde, y otros rara vez ó ninguna, haciendo confianza de los capataces que dirigen los trabajos y cuidan de los gastos. Esto nace de que por lo regular están en para- 
ges desabridos y muy incómodos por el frio, y por la intemperie que reyna; pero desde allí hacen conducir los metales al asiento, siendó en él donde se benefician, de cuyo modo los tienen á la vista para presenciar las labas, que es la última diligencia que se hace para sacar la plata.

35 Los metales se conducen de las minas á los asientos en llacmas ó carneros de la tierra, y en alpacas, siendo estos los animales mas propios para ello por lo escabroso de los caminos, cuya aspereza es tal, que los de otras especies se maltratarian mucho, $y$ no podrian traficar. Esta es una de las grandes providencias que tienen aquellos reynos, asi como en la Laponia son los renes los adequados para manejarse en la desigualdad de las montañas, y en los hielos. El carguio se hace en costales, cuyo ramo, $y$ el de las cueidas con que los atan sobre los animales, es la entrada mas segura y quantiosa que tienen los Indios del pueblo de Juli en el Gobierno de Chucuito, por ser allí donde se hacen, y se llevan á la mayor parte de los minerales del reyno.

${ }_{3} 6$ No es bastante que las minas sean de buena. ley para que sus trabajos se costeen con lo que rinden, ó que produzcan utilidades á los dueños: hay en ellas varios accidentes que interrumpen sus progresos: estos son las pérdidas de las vetas, dividiéndose en ramificaciones muy delgadas, hasta que enteramente no se descubre metal en ellas, en cuyo caso es precisa mucha destreza y buen acierto para volverlas á encontrar, y en el interin se trabaja sin recoger provecho, y con la duda de lo que durará la suspension de los metales. Los toros que se encuentran, y son unos nudos de piedra durísima que interrumpen la veta, ignorándose lo que tendrán de magnitud, ni qué partido convendrá mas, si el de atravesarlos con la mina, que se va abriendu, ó el Ec de 
de pasarlos rodeando por alguno de sus lados. Eo que se sabe de cierto es, que vencido el toro vuelve la veta á continuar con igual ó mayor riqueza que la que tenia ántes. Los terrenos de naturaleza falsos, que necesitan muchos empotrados, y obras de materiales para sostener los derrumbos y las aguas, quando son abundantes, y están muy profundas las minas, cuyo inconveniente suele equiponderar á sus mas sobresalientes riquezas, obliga á practicar socavones á mucho costo por donde se facilite el desagüe, cuya diligencia no en todas tiene proporcion, por no permitirlo la disposicion del cerro. Estos y otros varios embarazos minoran sensiblemente las utilidades en tales términos, que ponen á los dueños mas próxîmos á la pérdida que á las ganancias.

37 El trabajo se hace con Indios y Mestizos, unos voluntarios y otros de obligacion: estos últimos son los Mitaycs: la diferencia que hay en estas dos clases es, que los primeros son contingentes, y los otros seguros, pues en quanto á los jornales son iguales, siendo muy competente el que se les da, y arreglado á arancel, por cuya regla nunca es ménos de 4 reales de aquella moneda, aunque hay minas, como sucede en Potosí, que ganan un peso los dias que trabajan. Es vulgaridad muy errada la de que el trabajo de las minas es recio, y que aniquila estas gentes, porque ni uno ni otro sucede: siendo buena prueba la de acudir los Mestizos y otros Indios, á quienes no toca la Mita, á ofrecerse voluntariamente; y que los mismos Mitayos, concluidas las horas de su trabajo, se convidan á doblarlo, que es trabajar noche y dia, para ganar mas, ó todos los dias seguidos. Los trabajos que alli se ofrecen unos son subterráneos, y otros fuera, que consisten en acarreos de metales, y de materiales en las varias manipulaciones para el bereficio, sin que se reconozca que por 
por causa de ellos enfermen, ni les sobrevenga mal de consideracion. En este destino logran la mejor y mas puntual paga de quantas pueden tener en las otras ocupaciones; y así, á exemplo de los voluntarios, se quedan varios de la otra clase despues que concluyen el tiempo preciso de la Mita.

$3^{8}$ Los Mitas duran seis meses, y concluidos se cambian, haciéndose así para que se restituyan á sus pueblos, y cultiven las tierras que les pertenecen: despues tienen dos, tres ó mas años libres, sin volverles á tocar turno, segun son mas ó ménos crecidos de vecindario los pueblos. Ademas de los Mitayos siempre necesitan de gente libre las minas, pues la que goza 6 ú 8 de aquellos, ocupará 15, 20 , ó mayor número, á proporcion de las vetas que se trabajan. Por razon de la mucha frialdad de aquellos parages no se acomodan á ellos los Negros, que luego mueren, lo que no sucede con los Indios, cuyas naturalezas son propias para tales climas, y así los resisten sin pension.

39 Se dixo ántes que el consumo de azogue es la cantidad de este metal equivalente á la plata que se saca, y que lo que excede de esto es lo que llaman pérdida. Por esta regla puede sacarse plata sin pérdida, pero no sin consumo; y así, el que saca cien marcos de ella, ha de consumir en el bencficio por la amalgama 50 libras de azogue por lo ménos: de esto ha nacido la opinion de que se convierte en plata este metal, esforzándola con la circunstancia de no ser visible la plata en la mayor parte de los metales, como sucede con los que llaman pacos, que son de color de tabaco, y los que mas abundan: suponen para ello, que el mineral contiene materias propias para fixar el azogue, y purificarlo de los cuerpos extraños que tiene, y que los metales donde la plata es visible, que son los que llaman machacados, Ee2. 
se hallan en esta forma, porque en su mina abundáron las materias primitivas del azogue en tanta cantidad, quanto es su abundancia; pero que ademas de esta, que es sensible á los sentidos, la restante materia que está con ella combinada con el azogue que se le ircorpora, lo fixa y reduce á plata. Esta opinion, segun el sentir de los mas bien instruidos entre ellos, es efecto de la ignorancia, porque hay otras distintas causas para el desperdicio del azogue, sin que sea preciso ocurrir á que mude de especie, por razon de la mixtura con las partículas metálicas de la mina: concluyendo, que si las operaciones hubiese arbitrio para hacerlas en otra forma, se volveria á recoger todo el que se incorpora en las amalgamas; y en efecto, los grandes Metalúrgicos de Europa, que tienen conocimiento práctico de ellas, se admiran del desperdicio excesivo de azogue que se hace en las minas de Indias, atribuyéndolo á no valerse de los métodos mas seguros é industriosos para evitarlo.

40 En realidad, despues del largo tiempo que el mejor y mas pingüe patrimonio de la España son las minas de plata y oro de los dos Imperios de las Indias, hubiera sido conveniente establecer Flaboratorios de ensayos, donde la aplicacion adquiriese el conocimiento práctico y especulativo acerca del modo de bencficiar los metales, con aprovechamiento del azogue, y de los de plata y oro, pues á todos se extienden las pérdidas en muchas ocasiones por faltar la inteligencia para separarlos de los cuerpos extraños que los perjudican, como el vitriolo, el antimonio, el arsénico, alumbre, azufre, oropimente, y otros varios, que de ordinario acompañan á la plata, y es forzoso apartarlos ántes de hacer la incorporacion con el azogue, pues de no practicarse esto con la exâctidud que conviene, re- 
sultan dos daños: uno el de no sacarse toda la plata que contiene el mineral, por estorbar la interposicion, ó mezcla de alguna parte de estas materias, que el azogue se una bien, y abrace todas las partículas de aquella, que están contenidas en el mineral: otro, que absolutamente no se consiga la amalgama, siendo esto á lo que llaman disparar los cuerpos, porque subdividido el azogue en particulas minutísimas y ligeras, se escapa con el agua; y Ja plata, no habiéndose llegado á juntar, tambien se desaparece.

4I Logrado el fin de purgar los metales de plata de las materias extrañas que le dañan, y el de hacer las incorporaciones del azogue sin la fuerza de repasos que se les dan, se trabajaria en evitar los consumos de él; y quanto mas se aprovechase tendria ménos costo la plata: los mineros excusarian este gasto, y se harian útiles muchas minas que se abandonan por no alcanzar la ley de sus metales á los costos del beneficio; pues en el supuesto de consumirse I $_{2}$ anzas en cada marco, al respecto del precio que tiene en Potosí, son 6 reales lo que importa solo el coste del azogue. Ademas, habria tambien la ventaja de no estar pendientes del azogue para tener la plata; pues siempre que faltase aquel cesaría la extraccion de esta, y las minas quedarian inútiles. Por el contrario si el azogue no tuviese consumo, ó á lo menos este fuese corto, con una cantidad moderada habria bastante para algunos años, y en ningun caso sería sensible la falta de su abundancia. El descaecimiento de la mina del Almaden, que puede suceder de lo qual haya exemplar, es un peligro que amenaza á la subsistencia de las de plata. Las guerras que pueden sobrevenir es otro; y todo se salvaba con el medio que se ha dicho. Los mineros se aplican en quanto pueden al conocimien-

to 
to de sus metales, y al modo de aprovecharlos; pero recayendo en unas personas que nunca tuviéron principios de ello, ni conocimiento de la facultad de minas y metales, á quienes la falta de otra ocupacion les inclina á este exercicio, y el parecerles que para sacar plata basta mover las tierras, nunca pueden adelantar cosa de substancia, y quando lo consiguen es despues de bastantes pérdidas, quedando siempre con sobradas imperfecciones los métodes que descubren. Los beneficiadores son asimismo gente de pocos alcances, que aprenden lo que ven hacer á otros; y al paso que son hábiles en esto, no tienen la mejor disposicion para adelantar ni discurrir por sí, ni para mudar de método en las operaciones: conocen bien el mineral que contiene plata, pero no los medios de separarla con perfeccion de las otras materias á que está unida, cuyo punto es esencialísimo, como se ha dicho. No saben discurrir modos de aprovechar el azogue, que es otro muy principal. No ha faltado autor grave, y minero habil de aquel reyno, que lo ha conocido así; y que es de opinion que puede hacerse el beneficio sin consumirse, ni desperdiciarse azogue alguno. Este invento, en que debiera pararse mucho la consideracion, valdria tanto á la Monarquía como las minas de plata que le proporcionan las riquezas que posee, $y$ se las aseguraria para lo sucesivo, disfrutándolas sin desperdicios. A fin de que esto sea mas percetible será bien decir que se reconocen minas, cuyos metales en los ensayos pequeños manifiestan una riqueza increible, y trabajados en grande nunca dan la ley, y muchos disparan en el beneficio. 


\section{ENTRETENIMIENTO XV.}

Se trata del azogue y de la sal; materias precisas para el beneficio de la plata y de las minas de estas dos especies.

I $\mathbb{E}_{1}$ beneficio de los metales necesita dos ingredientes esenciales, que son el azogue y la sal: sin estos no podria tener lugar la amalgama, siendo el primero el que los une, de donde nace que su obra se llame incorpiracion; la segunda los dispone para que aquel pueda obrar, a cuyo fin los purifica de las muchas partículas extrañas que tienen. Ademas de la sal hay otros, de que tambien se usa para el mismo efecto, segun lo requieren las distintas materias que se hallan interpoladas con ellos. De este trabajo están libres en parte los metales que se benefician por fuego, pero son pocas las minas que tienen disposicion para ello.

2 El reyno del Perú fué privilegiado respecto del de Nueva España en la conveniencia de tener una mina abundante de azogue, con cuya proporcion no ha estado dependiente de España para el que necesita, y en ocasiones ha contribuido al otro con algunas porciones, cuyo auxilio ha sido muy importante, pues ha haber faltado, era preciso que hubiesen padecido mucho sus minas.

3 La de azogue se halla en el distrito de Guancavelica, nombre corrompido de Fiuanca Vilca, que son dos dé la lengua de los Indios, propios de naciones entre ellos; el cerro donde está se halla distante como legua y media de la villa, que tiene el mismo nombre, la qual está á su pié: los que le han 
han reconocido y visto, igualmente que el de Potosi, aseguran guardar mucha semejanza el uno con el otro.

4 No guardan igual semejanza en la disposicion interior, porque el de Potosí consta de muchísimas bocas, que dan entrada á otras tantas minas de distintos dueños, hallándose por todo él difundidas las ramificaciones de vetas; y el de Guancavelica solo tiene quatro entradas por lo mas alto, que es la cumbre del cerro, y tres socavones, que sirven para darle viento y desagüe, no porque tenga manantiales, sino para la que le entre de las goteras.

5 Esta mina no tiene extension á lo largo, y consiste en un gran pozo, bien que cerrado por la parte superior; sin mas abertura que las puertas de entrada que se han dicho, cuyo circuito es de 180 varas su extension, ó diámetro de 60 , y su profundidad de 513; en este ámbito han estado contenidos los metales que han producido el azogue con que se abasteció aquel reyno desde los principios, y fuera de él no lo hay; en lo antiguo fué abundante, pero faltándole extension, está reducida hoy á un esqueleto de palizadas, y algunos retazos, que habiéndose dexado con el fin de sostener la mina, y precaver sus ruinas, han podido escapar de la astucia de los mineros : les dan el nombre de estrivos; estos se disminuyen sensiblemente todos los dias por sacarse de ellos principalmente el azogue para el abasto regular. Pertenece á la Corona, y esto ha contribuido no poco á su mala conservacion, por la circunstancia de estar cedida á un número de personas que la trabajan por compañía, siendo la mayor parte hombres destituidos de posibles, y forasteros, que se recogen allí á tentar fortuna, sin principios, ni conocimiento del exercicio. El Rey les paga un tanto por cada quintal de azogue que le 
tregan, y les adelanta caudal para que empiecen á trabajar: en otros tiempos, que la capacidad de aquel gran pozo, ó depósito se hallaba en mucha parte macizo, lograban sobresalientes utilidades, sin perjudicar á la mina; pero no así al presente por la falta de ley á que han venido los metales. La villa, que es bastante grande, se mantiene de la Real Hacienda por las utilidades que dexa el azogue.

6 Se trabaja, como las de plata, con Indios de Mita, pero ademas de estos exceden los voluntarios, así de la misma casta como de Mestizos. La ley del metal en el dia es baxísima, correspondiendo á cada caxon, que se regula allí de 6 arrobas, siendo distinta esta medida que los de las minas de plata desde ménos de libra hasta $2 \frac{1}{2}$ ó 3 . Las débiles señales que han quedado de estrivos, tienen la de 8 ó Io libras; pero quando estaba en su fuerza la habia de 25 á 30 libras, que llamaban metal de Apuncbao, palabra India, que significa metal rico. Vese allí repetida una particularidad semejante á la de los metales de plata sobre la regeneracion de ellos; pues en los parages que han estado abandonados por largo tiempo, como de 60 ú 80 años, vueltos á habilitarse se encuentran en sus superficies unas costras, ó capas mas ó ménos gruesas, cuya ley es sobresaliente, y quitada vuelve á quedar la piedra de una calidad metálica, pero sin contener azogue, ó tan poco, que es despreciable. Esto hace creer que la mejoria de ley que se halla es posterior al tiempo del abandono; porque quando se hizo fué por no contener cosa de sustancia; habiéndose aprovechado con codicia los metales de ley regular en todos los tiempos, sin excusar trabajo para solicitarlos. A esto se agrega no ser natural que los abandonasen quando les quedaba el grosor de una vara, poco mas ó ménos, habiendo hecho grandísimas excavaciones en aquellos mismos sitios para exFf

traer 
traer otros, que tal vez no serian tan buenos como estos que se encuentran en los tiempos presentes. Si esto solo se viese en una parte, podria atribuirse á casualidad, pero experimentándose en todos los que se encuentran, cuya memoria está quasi perdida, hay bastante motivo para discurrir que la ley fué posterior al abandono; lo que comprueba tambien el poco grosor de las capas.

7 La piedra donde el mercurio se fixa es de un color particular; y aunque no lo contengan, se conoce por ella que en mas profundidad, o sacando algunas capas, se encontrará el cinabrio natural, que es la misma piedra, el azogue y el azufre unidos y mixturados. A esta piedra llaman metal de azogue, á distincion de la otra en donde nunca lo hay, á la qual dan el nombre de desmonte, y es al modo de pizarra. Esto asentado, se puede concluir que despues de sacado el metal útil de un parage, lo abandonaban, y quedaba macizado con los escombros que echaban en él de los otros cercanos. Los efluvios y partículas primitivas que constituyen el azogue, subiendo de lo mas profundo, circundan por las porosidades de la piedra metálica, que tiene disposicion para recibirlos, y al llegar á la superficie se detienen, no teniendo matriz por donde continuar la circulacion; y unidas con la piedra mudan su color obscuro, dándole el que tira á rubicundo mas ó ménos vivo, segun son abundantes las partículas mercuriales, y los azufres que les acompañan; de cuyo modo aquella piedra estéril va sobrecargándose de ellos, y reduciéndose á cinabrios: de esto resulta, que á proporcion que ha corrido mas tiempo desde el abandono, ó que la memoria de él está mas perdida hasta el descubrimiento, es mas ó ménos espesa la capa que se encuentra de la que contiene azogue. Suelen ser tan abundantes en algunas extremidades de la piedra metálica las partículas del 
DÉ I MOQUINTO.

azogue, que no pudiéndolas mantener fixas, é incorporadas en si, se ven en su propia forma; y sacudiendo la piedra contra una cosa dura, despide glóbulos de azogue, al modo que la piña de plata quando está en pasta; y si se comprime, despide el azogue superabundante sin otro auxilio: las piedras que contienen el azogue en su forma metálica, tienen un color de plomo brillante, que tira á rubicundo, y en donde él está hace briscado semejante á las cristalizaciones menudas que se suelen encontrar en las minas.

8 Tambien entre los escombros antiguos que han: pasado por el fuego, se encuentran algunas piedras que contienen azogue, de lo qual ha nacido, como en las minas de plata, persuadirse á que la piedra por su calidad es la matriz donde el azogue se fixa, comparando su propiedad á la de la esponja que recibe el agua; y que comunicándosele con el ayre las partículas sutilísimas del azufre, y de las partes que forman el azogue, vuelven á adquirir en parte la union que tenian en la mina con este metal. Que sea esto, ó el no haber quedado totalmente despojadas de él quando se hizo la operacion, lo cierto es haber mineros que se dedican, quando la mina no les produce con regularidad, á escoger ó pallaquear, y aprovechan lo que encuentran para sacar azogue.

9 Los lugares profundos de la mina, que despues de largo tiempo de haber estado ciegos con los escombros, se abren, tienen un ayre de naturaleza que mata de improviso si se respira, observándose en esto varias particularidades. Llaman á esta especie de ayre umpé; en su peso y elasticidad no se conoce circunstancia por donde pueda venirle esta propiedad, pues introduciendo un barómetro con industria donde lo habia, no mudó al mercurio sensiblemente de situacion de como estaba á la parte de afuera donde no lo habia, siendo tan eficaz y pronto, que al presentar Ff 2

tres 
tres velas de sebo unidas y encendidas, cuya luz era bien grande, luego que entráron en el umpé se apagaban, sin dexar señal de haber estado encendidas en los pábilos: tampoco en el termómetro se reconoció mutacion; ni en las demas qualidades de húmedo y seco, ó las que puelen percibirse por el olfato; y no obstante esto, quando falta precaucion en los trabajadores, al lligar á romper alguna antigua concavidad suelen quedarse muertos, y no volver con ninguna diligencia: para experimentar estos raros accidentes no es necesario que el agujero que se abre sea grande, basta el que hace la punta del pico ó de la palanqueta con que trabajan. Precávense de este peligro con el cuidado de no respirar al dar los golpes, quando sienten estar próxima á romperse la comunicacion, y luago que se abre presentan una luz, la que introlucen por toda la abertura en un palo quanto este pucde alcanzar; si no se apaga es señal de no haber umpé, pero por el contrario, extinguiéndose lo hay, y el tírmino es todo el espacio en donde sucede esto.

Io De esta qualidad tan rara del ayre, que no consiste en su peso, ni en su elasticidad, es muy dificil asignar la causa, pero se nota que se reproduce $y_{1}$ se mueve en el mismo ayre, dándolo á conocer la circunstancia de sobrevenir en algunos parages donde no se habia a tvertido; y sin esperarlo, ni haber antecedente para ello, se ve que las luces se quieren apagar, lo qual se indica de un modo raro. La luz entera se separa del pábilo, y sube hácia arriba con mucha prontitud, volviendo á baxar hasta el mismo pábilo, donde se mantiene un breve rato, y vuelve á reperi se el mismo sal.to, hasta que en alguno de ellos se des rarece enteramente: en estos saltos sube como media quarta, sin dexar en el pábilo señal alguna de haber estado encendido; pero quando sube demasiado 
DÉCIMOQUINTO.

es señal de que el umpé tiene fuerza, y entónces al segundo ó tercer salto se apaga. Estando en este térmí- no aun puede resistirlo por breve rato la vida de los hombres, pero quando de repente se apaga sin dar estos saltos, con la misma prontitud instantánea caen muertos.

I I La propiedad de moverse se percibe en que unas veces se mantiene en aquellas concavidades donde se descubre; ctras se adelanta á la calle por donde se hizo la entrada; y diariamente avanza alguna cosa: y se observa, que teniendo una luz en la mano donde no se perciben los efectos, y alargando el brazo á donde son sensibles, la luz se queda apagada; entónces con la que está en la otra mano se vuelve á encender; y quantas veces se repite el introducirla, tantas sucede el apagarse.

I2 Las personas que impensadamente se han encontrado donde empieza á haber zmpé, que no esté en toda su fuerza, sienten un hormigueo grande por el cuerpo, pero con particularidad en las extremidades, en la cara y en la cabeza, sordera y mucho sonido en los oídos, los ojos hinchados, como que se les quieren salir del casco, que son los efectos que ocasiona la extraccion del ayre dentro de la máquina pneumática. Para conocer si los del umpé eran provenidos de igual causa de rarefaccion de este ayre, se han hecho repetidas experiencias en dos parages diversos donde lo habia, y no podian subsistir luces encendidas: para esto puso unos lienzos al rededor de las narices y boca la persona que se preparó para entrar, y reteniendo el resuello, llevó el barómetro montado 4 varas mas adentro de donde se apagaban las luces; y colocado allí, salia y entraba para ver si hacia movimiento; lo reconocia distintamente con la claridad que comunicaba una luz puesta del lado de afuera 2 varas del límite del umpé. En esta forma ob- 
servó mantenerse el mercurio en I 7 pulgadas, I $\frac{\mathrm{T}}{2}$ línea: sacado afuera y puesto en el lugar donde estaba la luz, que era al mismo nivel, estaba en I7 pulgadas y 2 líneas; la diferencia era media línea, que nunca podia causar este particular efecto. En el segundo parage donde se hizo la experiencia, que igualmente el umpé no admitia luz, y es lo mas hondo de la mina llamada Hoyo negro, estuvo el mercurio en I 7 pulgadas y $2 \frac{1}{4}$ líneas. Al mismo tiempo se introduxo un termómetro, y tampoco tuvo alteracion, respecto de como estaba del lado de afuera; sacándose de aquí que la qualidad nociva de aquel ayre no procede de una gran rarefaccion, ni de ser mucho ménos pesado que lo que corresponde á la atmósfera de aquella altura. En estos parages no habia mas que una entrada sin tener correspondencia.

I 3 El modo de disipar el umpé es haciendo otra abertura al parage donde lo hay, y que el ayre tome movimiento; de cuya circunstancia puede inferirse venirle aquella qualidad de estar sin él algun tiempo enteramente. Si esto contribuye ó no á que pierda la elasticidad en el todo, ó en alguna parte, no es fácil averiguarlo, pero se dexa conocer le adquiera alguna propiedad particular dañosa á la vida, indicándolo así la prontitud con que esta se termina donde lo hay.

I4 Esta propiedad singular del ayre se conoce igualmente en distintos parages de Europa, en algunos pozos no muy profundos, y en la Gruta del Perro, segun la llaman en Italia; pero no basta la sola circunstancia de estar parado el ayre, pues son raros los pozos en donde se ve, lo que tambien sucede en las minas; pero se nota, que donde hay metal de algun provecho, ó lo ha habido, es mas expuesto que donde no lo hay; de lo que se colige, que los efluvios de este pueden comunicarle algunas partículas, que son con- 
DÉCIMOQUINTO.

contrarỉas á la vida. No sería extraño que la materia ignea ó la eléctrica, que se hallan esparcidas por el ayre, las absorviesen en sí los metales, y que por esto la luz no tenga subsistencia, faltándole en el ayre partículas correspondientes para animarla; pues entónces, sin haber mutacion en el peso ni en la elas. ticidad, podria producir los efectos que se ven. No sucede en aquella mina azogarse la gente que trabaja en ella, como se cree comunmente: en lo antiguo se dice era mas freqǚente este daño, y se atribuia á dos causas; una la porcion mayor de azogue que contenia el mineral; otra el modo de desprenderlo de la mina con el pico; entónces el polvo que despedia introduciéndose por la respiracion en la sangre, les causaba el mal. Los que al presente se azogan son pocos, y estos lo contraen en los bornos al tiempo de cargarlos, por entrar en ellos quando están todavía calientes; pero siendo los metales de poca ley, ni aun asi es comun.

I5 Los que se azogan practican allí un remedio fácil, con el qual se ponen buenos en poco tiempo, quando no pueden resistir mas, porque se ven en continuo temblor de todos los miembros. Estenuados y macilentos se transfieren á alguna quebrada de temperamento cálido. En ella se aplican á labrar la tierra, con lo qual sudan mucho y expelen el azogue, poniéndose del todo buenos; y despues que lo consiguen vuelven á tomar el antiguo exercicio, sin que les violenten á ello.

I6 Creyóse un tiempo que las minas de azogue eran en el Perú tan comunes como las de plata; y con escrupuloso cuidado se dispuso que no se trabajase en donde al parecer se habian encontrado indicios de ellas, para estorbar que en azogue y en plata se defraudasen al Rey los derechos Reales; pero quando llegó el caso de necesitarias, por el descaecimiento

de 
de la de Guancavelica, se halló ser engaño del poco conocimiento; y aunque se practicáron quantas diligencias dictáron el deseo y la importancia, solo se encontráron desengaños y el convencimiento de que las que en lo antiguo se tenian por minas de azogue, lo eran de hierro y de otras materias de esta naturaleza, cuyo color tira á roxo, como lo manifestáron muchos y prolixos ensayos que se han hecho. Las que se denunciáron en distintas provincias, y las del reyno de Chile, no han dado mas indicios de azogues que las otras. De esta escasez que se nota de tales minas, se reconoce la providencia del Criador, que como ménos útil que los otros metales, por su rara qualidad de ser fluido é inestable, aun siendo tantas las de los metales preciosos de plata y oro que distribuyó en todo el mundo, y de que hizo ostentacion en aquellas dos Américas, son tan raras las que se conocen de azogue, que se hallan reducidas á la de Guancavelica en el Perú, la del Almaden en España, y la de Frieste en el Fruili; pues de haber otras, son de poca reputacion, y no las hay en la América Septentrional, cuyas minas de plata no son ménos pingües que las del Perú, como lo tiene acreditado la porcion que se saca de ellas todos los años.

I7. El azogue se emplea tambien en amalgamas de las minas de oro quando este se halla en partículas tan diminutas, que no se puede recoger por la fundicion, ni por las labas. De algun tiempo á esta parte se usa de él en Portovelo con motivo de haber encontrado en los cerros inmediatos minas de este rico metal, las que en dictámen de los inteligentes prometen aumento, á medida que se vayan adelantando sus trabajos; pero como allí no ha sido regular hacer consumo de azogue, padecen escasez; y esto perjudicaba á los progresos que deseaban sus dueños.

I 8 Proveense las minas de la sal que necesitan; 
DECIIMOQUINTO.

unas de la que se coge en el mar, y otras de la que se saca de las minas que hay propias de ella, segun la proporcion en que estín, siendo uno de los renglones de expendio que tienen, y en las que se hallan muy retiradas es bastante costoso. Goza en este par ticular aquel pais la ventaja de no ser necesario que intervenga el trabajo ó industria de los hombres: se forma la sal, ó la congela la naturaleza de sí misma, sin mas pension que irla á coger. En el distrito del pueblo de Chilca, que es del Corregimiento de Cañete, baña el mar con las crecientes algunos valles entre alturas de poca elevacion, dexando en lo mas hondo lagunas, que se renuevan de continuo. Este agua, por la calidad del suelo, se congela en sal, siendo tanta: su abundancia, que se abastece con ella mucha parte del pais, pero no tienen facultad para extraerla de allí otros mas que los Indios de aquel pueblo, y son estos los que se ocupan en conducirla á los demas parages donde se necesita. A esta semejanza hay en aquellas costas otros lugares, que son salinas naturales.

I9 En la parte alta del Perú, que parece haberla proporcionado la Providencia para depósito de toda suerte de minerales, los hay de sal, y son en la misma disposicion y estructura que las de los metales : en ellas hay las entradas regulates, y la sal se halla en cuerpo duro, macizo y continuo como la piedra: se corta á fuerza de pico, en pedazos proporcionados, para que las bestias de carga puedan llevarla; y así se conduce á las poblaciones y á los minerales : á la vista es engañosa, reniendo semejanza de piedra de color morado, que tira á obscuro, con vetas al modo del jaspe, y la venta no se hace por peso ni por medida, sino por piedras, en cuyo tamaño es poca la diferencia. De estos minerales de sal se encuentran en casi todos aquellos paises, y su especialidad consiste Gg

en 
en la dureza, en el color, y en estar en aquellos cerros de tanta elevacion al igual de los de plata y de mercurio, cuya variedad contribuye á hacer admirables en todo las obras de la Providencia.

20 Puede ser digno de repararse, que habiendo sido tantas las riquezas, especialmente del oro que se sacaba en las islas de Santo Domingo y de Cuba en los tiempos cercanos á su conquista, al presente se encuentran tan cortos indicios de ello. En la de Cuba snbsisten vestigios de antiguas minas con solo el nombre: a prca distancia de la Habana, por la parte de Bacurano, hay unos cerros de poca elevacion, y allí un parage que llaman la Mina, por haberla, aunque ni está corriente, ni parece haberlo estado de mucho tiempo a esta parte, sucediendo lo mismo á las otras. Hay noticia no obstante de que lavando las arenas del arroyo Escambray, que está tres leguas de la villa de Santa Clara, en el hato de Manicaragua, y en algunos otros de la jurisdiccion de la Trinidad, se saca algun cro en polvo y pagillas, refiriéndose otro tanto de los que están hácia la ciudad de Holguin; pero son muy cortas estas señales para compararse con la fama de la riqueza antigua. En la isla de Santo Domingo no son tampoco de mas entidad que en aquella, y á esta semejanza sucede lo mismo en las otras de donde se saco algun oro en los tiempos de su descubrimiento.

2 I En la Luisiana uno de los incentivos que tuviéron los Franceses para poblarla á costa de muchas Vidas gue perdiéron en los principios, fué la esperan$\mathrm{za}$ de encontrar minas de metales ricos, guiados por la conjetura de ser un mismo Continente con la Nueva España; y aunque en su solicitud y descubrimiento han practicado algunas diligencias, y en efecto han logiado descubrir algunas de plomo y de cobre hácia la parte de los Ilinueses, pero ninguna de oro ni plata. 


\section{ENTRETENIMIENTO XVI.}

\section{Trátase de los fosiles, $y$ particularmente de las petrificaciones.}

\section{I $\mathbb{I}_{\text {a }}$ sido siempre unos de los desvelos de los} hombres el averiguar lo pasado, y descubrir testimonios visibles que lo convenzan; y quanto mas remotos son los asuntos, mas eficaces y mayores son las diligencias para conseguirlo. Con este designio no ha quedado cosa que no registre la diligencia, ni ha habido obstáculos que no venza la constancia á costa de las mayores fatigas. Los hombres se han repartido por el mundo con el objeto de exâminar por sí lo que refieren las historias, sin dexar region exênta de sus especulaciones, ni lugar á donde no les hạya introducido este deseo de saber. Este mismo fin es el que ha dado lugar al estudio de las antigüedades, en el qual la inteligencia, alumbrada de los descubrimientos, usa de sus facultades para descifrar los testimonios de lo pasado desfigurado con el tiempo; y por su medio vienen á descubrirse convencimientos de los mas prodigiosos acaecimientos del mundo.

2 No hay quien ignore el círculo continuo que hacen las cosas, decayendo despues de haber llegado al punto mas alto de su auge, y pasando con la misma aceleracion que subiéron al mas ínfimo de su ruina, cuya alteracion es el testimonio mas irrefragable de la inestabilidad á que están sujetas. Los Imperios mas famosos se han deshecho y desvanecido, to mismo que el humo se disipa en el ayre. Las ciudades mas opulentas, populosas y ricas se han aniquilado, deshaciéndose los mármoles y los bronces que las $\mathrm{Gg} 2$ ador- 
adornaban, como si sus fundamentos hubiesen sido aprehensiones de la fantasía: y hasta las naciones se han extinguido, como si se hubiesen desaparecido de entre las gentes. El mundo mismo por partes tiene variedades, y las montañas que representan mas corpulencia, y parecen incapaces de mutacion, experimentan con el rrascurso de los tiempos, y los acaecimientos que sobrevienci, novedades muy sensibles, $y$ disminucion de sus alturas. Los rios mudan de cauce; y unos pierden la profundidad que ántes tenian, al paso que otros se abren distintos caminos para dirigirse al mar. En este no son ménos sensibles las mutaciones, como lo testifican las playas, los puertos, las ensenadas, los promontorios y las islas; unas que se rompen ye disminuyen, otras que aparecen de nuevo como si creciesen desde lo profundo del fondo; y en este modo con el curso de los tiempos todas las cosas corren, haciendo un periodo cortinuo de variciones.

nit Este convencimiento induce á indagar los acaecimientos mas notables del mundo paral saber lo que fué én su primitivo estado, y consiccrar las mutaciones que ta tenido hasta llegar á la disposicion en que se halla al presente, pasando porgrados de una positura á erra, sin que se noten las variedades, hasta que al intermedio de muchos años y de siglos las hácen sensibles. No se satisface el gusto con las relaciones que se adquieren de la lantigüedad, ya sea por no hallarse con la extension ó claridad convenientes, ó por sospecharlas desfiguradas con interpolacion de las fábulas que vician lo que está enlazado en ellas: á que se agrega la particular recomendacion de afianzarse con señales visibles, que desvanezcan todo gérero de duda en lo que se adquiere de la tradición, y la de ver que en medio de las grandes alteraciones que han sobreyenido en el mundo, se conservan reliquias de aldition los 
los acaecimientos mas grandes y remotos. No hace muchos años que la liberalidad del Rey de Dinamarca despachó varios sabios de aquella nacion, para que pasasen al Asia y parte del Africa, y corriéndola por todas partes, exâminasen prolixamente una serie de asuntos de la antigüedad, cuyo catálogo componia un volumen de bastante bulto; y para amplificarlo mas en observaciones de entidad, fuéron convidadas las Academias y Congregaciones de sabios de Europa, para que propusiesen los puntos y asuntos que les pareciesen convenientes, á fin de evacuarlos con igual exâctitud. Esta expedicion, que tenia en espectacion á los sabios y curiosos, no llegó á perfeccionarse, por haber experimentado la desgracia de morir en ella los comisionados, á excepcion de uno que pudo escapar del rigor de l.s intemperies, y de las grandes fatigas que experimentáron en este encargo. No obstante este sensible contratiempo, apetece el deseo ver las resultas de lo que habian adelantado, aunque se crea haber quedado incompletas las averiguaciones. - 4 Ctros muchos han tomado por objeto averiguar per sí mismos las cosas de la antigüedad para hacerlas comunicables al pútlico, contribuyendo á que se determinen á ello, sin reparar en los peligros, ni en las incomodidades, iguales motivos á los que van expresados. Las Indias Españolas no han estado en el caso que las otras partes de la tierra, concurriendo para ello dos causas: la primera, ser unos paises modernos en el descubrimiento: la segunda, la total ignorancia que se tenia de ellos ántes de descubrirse, sin ha- ber autcr antiguo de quien seguramente se pueda decir que diese ni aun confusa luz de sus particularidades; y hallándose separadas enteramente de las otras tres partes, segun lo que se tiene reconocido hasta aquí, no participáron en ningun modo de los acaceimientos y grandes revoluciones que han sobrevenido 
en estas otras, despues de la renovacion total de la tierra con el Diluvio, manteniéndose por espacio de tantos siglos con entera independencia. Se agrega á esto ser tan reducidas las memorias que se han hallado de las suyas particulares, que no pasan por lo tocante al Perú de los trece Incas, que se sabe haber reynado ántes del descubrimiento y conquista; los quales, dándoles lo mas que pueda reputarse, será en cada uno $3^{\circ}$ años de reynado, que no llegan á 400; los que rebaxados de los 1525 , que se contaban quando se empezó la conquista, vienen á ser I I 25 de la Era de Christo; con que los sucesos y alteraciones de aquella parte se reducen á seis siglos y medio : época la mas antigua, en que puede considerarse ser extensiva su historia. De esto se ve haber subsistido como en lo confuso de un caos, mediante no saberse cosa alguna de lo que fuese, ni de lo que sucedia entre sus habitadores en el largo espacio de mas de 4000 años; y aun en los quatro primeros de los trece Incas tiene mas parte el discurso de los Historiadores en Io que se refiere, que las verdaderas Historias fundadas en los Quipos. Por esta causa son escasísimas sus noticias, no hallándose señales que dirijan el discurso de los tiempos mas retirados, ni aun con el defecto de la confusion.

5 La total reforma del antiguo mundo, y su renovacion, completa con el Diluvio universal, fué como una segunda creacion. Rara será la nacion de gentes que no conserve alguna idea de ello, aunque en muchas se mezcle parte de la fábula con lo verdadero; y aun entre las Bárbaras no dexan de alcanzar confusamente sus especies. Por lo tocante á los Indios, hay autores que aseguran haberse encontrado, al tiempo de la conquista, algunas noticias de este famoso acaecimiento, aunque desfigurado y confuso. En los tiempos presentes no se halla en ellos indicio alguno que 10 
lo convenza, sucediendo esto con los civilizados, ó que fuéron conquistados, como con los que han subsistido en su plena libertad. Esta falta de noticia puede nacer de la indiferencia con que miran el curso de la vida, como se explicará en su lugar; y así no saben lo que fué Diluvio, ni tienen idea de sus portentosos efectos, no siendo capaces de comprehenderlo aunque se les quiera explicar, no debiendo parecer extraño mediante no descubrirse en ellos mas luces que las de la vida animal, y la memoria de los Incas sus Soberanos, de cuya época no pasan sus mas antiguas noticias.

6 Entre las ocupaciones de los Historiadores y Antiquarios ha sido de las que mas han llenado su atencion el descubrir señales del Diluvio, que no se puedan equivocar con otros acasos posteriores, y son tantas las que ha encontrado la aplicacion, que no tienen número, sacando de 10 alto de las montañas mas elevadas, y de la dureza de sus entrañas peces del mar, embutidos y engastados en el macizo de las peñas; algunos de ellos en tal disposicion, que aun se conserva la espina principal y la cabeza, estando lo restante del cuerpo y las escamas señaladas, y con el lustre que tienen quando están en el animal. Por este término se sacan conchas petrificadas de distintas. especies, y de las mismas que solo se crian en el mar, á diferencia de los caracoles de tierra; y de las conchillas que suelen encontrarse en algunos rios. Tambien se sacan arborizaciones marinas, corales blancos y roxos, y toda suerte de plantas que se crian en el fondo del mar, las quales están encerradas en el corazon de las piedras, sirviendo de señal incontestable de haberias dexado allí las aguas.

7 Las montañas de la parte alta del Perú, segun se ha dicho en el segundo Entretenimiento, exceden en elevacion á quantas se conocen en las otras partes del 
del mundo. Las diligencias que se han repetido en estas no habian tenido proporcion en aquellas, dudándose si tambien se hallarian las mismas señales, procedido de ser poco freqüentadas de personas inteligentes. La parte correspondiente al reyno de Quito fué reconocida quando se practicó la medida de los grados de Meridiano, para averiguar la figura y magnitud de la tierra; pero aunque con este motivo estuviéron freqüentadas sus montañas, no se descubrió en ellas señal alguna de las que indican la estada de las aguas allí: y siendo lo largo del espacio que entónces se andubo de 90 leguas, empezando algo al Norte de la Equinocial hasta el Sur de la ciudad de Cuenca, se creyó que en lo restante de la tierra alta, que corre por el Perú, sucederia lo mismo, cuya circunsrancia si se llegaba á verificar sería particularidad de aquel pais, respecto de lo que se advierte en los otros, y tanto mas digna de reparo, quanto son mas dilatadas aquellas eminencias que corren desde el Ismo de Panamá hasta el Estrecho de Magallanes, ó cerca de él un espacio de 60 grados de Norte á Sur, que es la saxta parte de la relondez de la tierra.

8 En el reyno de Chile, por las cercanías de la Concepcion, se habian visto minas de conchas en cerros algo elevados, pero su altura apénas llegará á ser la śptima parte de la que tisne el territorio a!to; de modo que el encontrarse allí no concluye que las debiese haber en él. Además de esto, las que se encuentran en Chile no son petrificadas, ni unidas haciendo cuerpo con los peñascos, sino sueltas en bancos, ó capas enteras de ellis, rodeadas por todos lados de tierras, segun la calidad de la de aquellos lugares.

9 Esta duda se halla ya del todo desvanecida con las petrificaciones que hay en la parte alta, en los cerros que se elevan cerca de Guancavelica, y: aun 
DECIMOSEXTO.

en el mismo donde está la mina de azogue, donde las hay en abundancia y con diversidad de especies, cliyo exemplar convence que las debe haber en otros muchos parages de aquellos dilatados y altos paises.

Io En los peñascos que aparecen en aquellas montañas, quando la continuacion de las lluvias descarnan la tierra que los encubrian, se ven embutidas las conchas enteras petrificadas, y haciendo cuerpo, de tal modo, que la parte que fué concha siempre se distingue en el color, en la estructura, y en la qualidad de la materia, de la piedra que las rodea, $y$ de la que maciza el hueco interior entre sus dos tapas; así rompiéndola, se reconoce en ella cada cosa distintamente, sin que pueda padecer engaño ni equivocacion la vista : la mayor porción de ellas es de la especie de bibalbos; y en quanto á los tamanos no hay regla fixa, encontrándose pequeñas como de una pulgada, y aun algo ménores, y grandes hasta de quatro pulgadas por su mayor largo, $\operatorname{con} 3^{\frac{1}{3}}$ de ancho: otras hay medianas; las chicas son por lo comun de figura convexâ en las dos tapas, sin discrepar la una de la otra; y las de los otros tamaños son de la especie que comunmente llaman concba de peregrino, teniendo la una tapa convexâ, y. la otra plana; todas son estriadas, y derechas las estrías, encajando las de una tapa con las de la otra perfectamente.

I I Estas conchas dan á entender haber padecido algo con el movimiento pronto y fuerte de las aguas, $y$ con los choques que tuviéron entre si, pues se encuentran algunas en que las dos tapas se hallan desquiciadas, y no obstante están cerradas, pero sobresaliendo la una de la otra alguna cosa, y sin ajustarse las estrías entre sí; dexándose percibir que el nervio ó tendón que las juntaba por la articulacion, se relaxó, y dió lugar á que perdiesen la igual$\mathrm{Hh}$

dad. 
dad. No sería tampoco irregular que la compresion que hacia en ellas la materia, quando se iba endureciendo y petrificando, no siendo igual, y el animal, hallándose ya muerto, precisase la una de las tapas á resbalar sobre la otra la cantidad que permitiese la relaxacion del tendon.

I 2 Por la circunstancia de estar completas las dos tapas y cerradas, se da á entender, que el animal estaba vivo quando la materia que las contenia se endureció, porque lo regular, quando este muere, es perder la fuerza del tendon, y abrirse la concha; y así parece sin duda fuéron llevadas desde los abismos del mar á aquellas grandes eminencias, y se mantuviéron vivas interin que la materia de las piedras estaba líquida; pero luego que empezó á endurecerse, faltándoles la humedad con que se mantenian, muriéron los animales, y ellas no pudiéron abrirse, porque la compresion de la materia que rodeaba, y se iba endureciendo, no les daba la liberdad para apartarse.

13 La materia la pidífica donde están las conchas no es en todo igual, unas se sacan de color negro, cuyo grano es muy fino, y á correspondencia su peso y dureza: otras de color ceniciento obscuro, no tan dura y pesada como aquella; y otras en piedra blanquecina porosa, sucediendo esto segun la calidad de las canteras ó de los cerros, cuyo interior ocupan. Hay algunas en peñascos tan duros, que no ceden al pedernal, y cuesta dificultad sacarlas enteras; pero al practicarlo se reconoce que la piedra $y$ la concha no hiciéron union perfecta, pues á la fuerza de los golpes, dados con alguna maza de hierro, se separan, quedando la concha con sus estrías dividida de la piedra, y señaladas en esta las mismas estrías en toda su profundidad.

I4. Ademas de las conchas de las especies que se han 
han explicado, se encuentran bastantes de otras diversas: estas son llanas univalbas, de la clasé de hongos, cuyas estrías salen de un punto que no está precisamente en el centro de su ámbito, y hacen tres ó quatro curvaturas, encontradas hasta llegar á los bordes de ella, siendo estas en figura de $S$ repetida: el tamaño es vario, pues llegan las mayores á tener 5 pulgadas de diámetro por donde $m$ as se extienden, en una figura quasi oval: su grosor es de una línea con poca diferencia, y se distingue, como en las otras, de la piedra donde está, notándose la misma circunstancia que en las otras, de romperse aquella separándose la concha, y dexando las estrías enteras como que nunca tuviéron cuerpo, ni formáron perfecta union con ella.

I5 Supuesta la grande altura que tienen aquellos parages respecto del mar, y la particularidad de hahlarse estas en el corazon de aquellos peñascos que forman el corazon ó interior de los cerros, se hace preciso inferir que no eran piedra quando las aguas las depositáron alli, y que su dureza es adquirida despues, siendo entónces la materia tan líquida, que penetraban por ella sin impedimento los varios mariscos que se encuentran, pues de otro modo era imposible: siendo pues líquida la materia, que ahora es la mas dura, pesada y compacta, parece que las otras ménos compactas y recias lo serian igualmente, siguiéndose de ello la precisa conclusion de que toda aquella tierra elevadísima debia hallarse en la misma disposicion.

I 6 Aquí se ofrece una dificultad bien rara sobre el estado líquido de la materia en los tiempos inmediatos despues del Diluvio, y es, que en esta disposicion no podia mantenerse elevada, sin ponerse á nivel con las otras partes que estaban inferiores. La solucion que esto tiene es suponer, que Hh 2

10 
lo mas interior de las altas serranías no experimentó las grandes mutaciones que hubo en las partes mas próximas á la superficie; y que sirviéndoles de apoyo las que no se liquidáron, se sobstuviéron y fuéron agregando á ellas las que lo estaban, y por esto no corriéron á buscar la igualdad; á lo que se agrega, que ántes de dividirse en quebradas profundas de mucha anchurà, eran territorios poco ménos que iguales, donde se mantenian sin notable desjgualdad, las que al presente son montañas: esto es lo mas natural y verosimil, pues solo de este modo se puede comprehender que las conchas del mar estén embutidas en las peñasquerías, y que se sobstuviese la materia á donde alcanzó la liquidacion, formando aquella altísima cminencia de tantos centenares de leguas en lo largo que hace la parte alta de la América Meridional.

17 Es natural que así como quedáron conchas en to interior de las montañas, y de sus bancos ó canteras, se detuviesen muchas en la parte exterior de su superficie, pero como ménos arraygadas y fixas fuéron las primeras que corriéron á buscar su primer centro, siendo esta la causa de no encontrarse sueltas y esparcidas sobre la tierra, ni sin estar petrificadas. La disminución que tienen las montañas, sin embargo de su solidez y de la dureza de la materia que encierran, llega á ser perceptible en algunas de estas mismas conchas petrificadas que se encuentran en los rics que descienden de ellas. Estas se ven separadas enteramente de la piedra, dende estaban contenilas algunas tan perfectas en sus estrías, que no les falta cosa alguna, y otras conservando akgun pedazo pequeño de la piedra exterior, como testimonio de haber sido desmembrada de ella: todo lo que con las lluvias, los soles, los bielos y las nieves se separa de aquellas montañas, 
DECIMOSEXTO.

hasta descarnarse lo interior de sus canteras, y dividirse las conchas que estaban embutidas en ellas, es disminucion que tienen de su primitivo estado, y á proporcion fué mas facil que las que no se hallaban tan sólidamente retenidas, siguiesen con las aguas, sin dexar indicios de haber estado allí, á ménos de suceder lo que se ve en la Concepcion de Chile, de quedar baxo de tierra, cubiertas con un grueso banco de ella, cuyo volumen en los tiempos inmediatos del Diluvio no es facil determinar. Otra señal no ménos convincente de haber estado las aguas en aquella vasta eminencia, y de la liquacion de la materia exterior de la tierra, se hace perceptible en las concreciones de varias piedras, que en canteras considerables se encuentran igualmente en los cerros. Estas consisten en una porcion grandísima de guijos menudos, unidos por medio de otra materia lapidífica, y el todo forma una argamasa durísima, que es lo que corresponde á la naturaleza de la materia que las incorporó: al paso que con la disminucion de la capa exterior que cubre las montañas, van descubriéndose en ellas los bancos considerables de canteras, aparecen igualmente los de esta especie, siendo de una magnitud bien grande, pues por espacio de un quarto de legua, y aun á mas distancia, se reconoce extenderse lo que de ellos se manifiesta á la vista. La piedra, ó guijos que hacen la concrecion, es como queda advertido, pequeña, del tamaño de nueces, y menores; diversas en las figuras, unas chatas, otras ovales, y tambien mas redondas que largas: la materia que las une es de color de ceniza blanquizca, con grano, pero durísima y pesada.

18 Estos guios en sí son como las conchas precedentes al Diluvio, y la concrecion se formó de sas lesultas, mediante que para ello era preciso que 
la materia que las unió estuviese líquida para que pus diese llenar los intersticios que habia entre ellas, consideradas en monton, pues de lo contrario se hubiera hecho la concrecion perfecta en las partes exteriores, y en lo interior habria quedado solo con la presion que se comunicaban unas á otras. Corrobórase esto con la circunstancia de que en aquellos mares es muy comun en lugar de arena, ó de lama, ser su fondo cerca de las orillas de este género de guijos, lo qual se ve así por ámbitos de bastantes leguas, de suerte que lo que en otras partes es arena, en esta es guijería sin mezcla ni union de aquella. Los embates disformes que las aguas tendrian durante el Diluvio, con el mismo poder que lleváron las conchas á aquellas eminencias, llevárón sin duda la guijería, haciéndose entónces una mezcla de las cosas que ántes estaban divididas, unas como propias del elemento del agua, y la otra como perteneciente al de la tierra. Puestas allá, y envueltas en una materia que se hallaba líquida, se incorporáron con ella: las que encontráron la que era propia para petrificarse, formáron concrecion; las que no, quedáron sueltas, y por esto se encuentran tambien, otros bancos donde la guijería no la forma, hallándose suelta y. mezclada con distintas especies de tierras; pero como las de esta clase se hallan mas expuestas á rodar con las aguas, no son subsistentes como aquellas despues que pierden la capa exterior que las mantenia, siendo en tal modo las concreciones que salen de la tierra, que al modo que los picachos de la demas peñasquería, se levantan de ella á proporcion que se van descarnando de tierras.

I 9 En estas concreciones se ven, como en las conchas, dos materias distintas, que se hallan incorporadas, ó unidas la una con la otra. Esta cir- 
DECIMOSEXTO.

cunstancia obliga á conocer que la una fué primero que la otra; y que la que hizo la union se hallaba líquida quando la que se unió se introduxo en ella, cuya obra no pudo perfeccionarse en otro tiempo que quando con las aguas experimentáron la mayor alteracion todas las cosas de este globo.

20 En las peñas que contienen conchas petrificadas se encueritran tambien otros cuerpos, que indican ser maderas, persuadiéndolo así la disposicion de las fibras y porosidades en la que se distingue la corteza de las otras partes leñosas. Esta circunstancia aumenta la particularidad por no criarse árboles grandes ni pequeños en las eminencias, bien que en algunas distancias de ellas, hácia las partes ménos rigidas, hay los casis, especias, y quinuales, de que se ha dado noticia; y así en el cuerpo de un mismo peñasco se descubren las señales de las cosas del mar y de las producciones de la tierráántes del Diluvio. De esta ro es posible conjeturar si entónces era mas fecunda de plantas mayores que lo que se ve despues; pero sí, que para que sucedicse sin salir del órden natural de las cosás, era preciso que el clima fuese mas benigno, y para ello aquella parte de mundo habia de ser ménos elevada de lo que se halla, respecto de que de su mayor elevacion resulta la ménos densidad del ayre, y de esta la frialdad y congelacion.

2 I De esta mayor elevacion que tiene aquella parte de la tierra, comparada con las otras, se saca por conseqüencia, que aunque se le llama Nuevo Mundo, con atencion á su descubrimiento por los Europeos, es verdaderamente el Mundo Viejo, ó mas antiguo, porque fué el primero que salió de las aguas despues del Diluvio; y aunque no fuesen mas que instantes los que precediesen de la aparicion de las tierras mas altas á las que no lo eran tanto, basta

es - 
esto para que tuviesen la antelacion.

22 Sucle descubrir la casualidad ciertas cosas, que hacen titubear el juicio, sin acertar á darles una interpretacion adequada, y tal, que no dexe dudas y dificultades. Esto sucede con unas pirámides que se hallan en el Llano de Paucara, las quales al parecer son obra de la naturaleza, aunque por otra parte no se conforman con ello las circunstancias que en sí tienen. El pueblo de Paucara es uno de los que componen la Doctrina, ó Curato de Acobamba en la Provincia de los Ángaraes, del Gobier. no de Guancavelica. El clima es de lo mas firio dé aquellos en donde no granan las sementeras; allí las serranías se apartan., y dexan espacio bastante dilatado para una llanura, que hace algunas pendientes en forma de lomas. En esta llanura se ven sembradas unas piedras en forma de pirímides, redondas, cortadas con toda perfeccion, siendo cada una de una pieza: en su altura hay variedad por serlo unas mas que otras: algunas llegan á ro varas, otras á 8 , y otras mas pequeñas; pero sus superficies son seguidas é iguales, yendo á rematar en punta; y muy pocas se hallan truncadas por arriba, lo que debe atribuirse á la ruina que causan los tiempos; en quanto al número no se puede determinar, estando repartidas por aquellas lomas, sin que en sus inmediaciones se encuentren otras piedras de diferente figura: el color de estas es blanquecino, y no se reconoce en ellas grietas ni rajaduras. Algunos han pensado ser obra artificial de los Indios, teniendo por muy extraño que pueda serlo de la naturaleza: á la verdad se hace dificil concebir quáles fuesen los moldes de que esta se valió para dexar en lo espacioso de aquel llano unas obras tan admirables, en figura de tanta perfeccion, y que fuese á poner allá los modelos de lo que el arte habia de imitar despues 


\section{DECITOSEXTO}

pues en las que eligiéron los Egipcios con el fin de inmortalizarse.

23. A que sea sola obra de la naturaleza, inclina el crecido número que hay de ellas. La circunstancia de ser de una sola pieza la altura y magnitud, y la dureza de la piedra, da motivo para discurrir bastante sobre las que erigiéron los Egipcios, cuya idea pudo haber sido heredada por la sucesion de los ticmpos; pero si por el contrario se atribuyen á obra de los hombres, es forzoso pensar haberla llevado de donde la tomáron los Egipcios: en este caso se abre camino con alguna mas facilidad para discurrir sobre el orígen de los Indios, y el modo con que se pobláron aquellos paises, sobre que se ha pensado tanto, sin acertar á determinarlo de un modo que satisfaga á la razon.

24 En el reyno de Quito se ven las guasas que servian de monumento donde se enterraban los Indios; y aunque no son precisamente en figura de pirámides, tienen semejanza con ellas en quanto lo permite la tierra, que es el material de que las hacian, y la precision de darles la pendiente necesaria para que se sostuviesen. En la parte de Guancavelica, y por aquellos paises que corren en adelante, no se encuentra este género de monumentos, porque en cada pais varían los usos, aunque generalmente eran propensos á conservar la memoria de los que morian: hay. ademas de esto tradicion de que en el llano de Paucara era el parage á donde se iban á enterrar los $\mathrm{Cu}$ racas y Caciques de aquellas comarcas que sobresalian en poder, y eran de la primer consideracion; y así no sería irregular que hiciesen erigir las pirámides que ahora se ven, así como en el reyno de Quito. Establecian las guacas, que era obra no ménos grande, por la cantidad de tierra que entra en ellas, siendo unos cerros artificiales, hechos en forma de pan de Ii azú- 
250

ENTRETENIMIENTO

azúcar de bastante altura. Esto no se oponé á que en otras provincias del Perú sean igualmente regulares las guacas, como sucede en la parte baxa, que tambien son comunes, y lo indica el nombre en su generaliuad.

25 Las piedras monstruosas de la fortaleza del Cuzco han hecho dudar de la posibilidad de su conduccion á los parages dorde están colocadas, dando campo á discurrir que pudiéron poseer los Indios el arte de fundirlas, como se supone en los antiguos: solo considcrándules esta habilidad pueden vencerse las iificultades que se ofrecen sobre la formacion de las pirimiles, que por qualquier medio que se elija no se les encuentra solucion; y si se les concede á los Indios este atte, será fácil deducir su orígen en donde lo tuviéron los Egipcios, mediante ser una misma la obra, y las dificultades para hacerlas. 


\section{1}

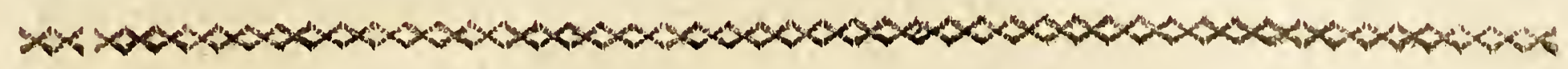

\section{ENTRETENIMIENTO XVII.}

\section{De los Indios de las dos Américas, $y$ de sus costumbres y usos.}

I $\mathbb{F}_{\perp}$ ntre los asuntos que principalmente llaman la curiosidad de los hombres, es uno el conocimiento de las gentes de varias regiones; el de sus costumbres, usos y propensiones, nacido de que teniendo todas un mismo orígen, es tan extraordinaria la variedad que se reconoce entre unas y otras, que parece á primera vista dificil combinar la evidencia de aquel principio con la diversidad de propiedades que en muchas se advierte. Esta suele ser en algunas tan sensible, que en todo se notan diferir. Así sucede en el color, en las facciones, en la contextura, y mucho mas en las costumbres, en el género de vida y en los usos. Unas de las que mas se apartan entre sí son las que se diversifican por los tres colores, de blancos, negros $\mathrm{y}_{\text {, }}$ roxos: cada una de estas se divide y subdivide despues en tanto número de otras, quantas son las regiones, los estados y las provincias. De lo blanco á lo negro hay toda la distancia que permite la oposicion de los dos colores mas opuestos, como comparar lo claro del dia con las tinieblas de la noche: el colorado es un medio entre los dos, distando tanto del uno como del otro: este es el de los Inúios; y aunque ellos no paran la consideracion en ello, los de la parte del Norte se dominan bombres colorados, para distinguirse de las otras dos especies. No ha faltado quien intente dar solucion á la variedad de colores en el linage humano; pero muy distante de conseguirlo, ha sido imaginario quanto se ha explicado Ii 2. so- 
sobre ello, hallándose falsificado el sistema con las mismas razones en que se ha fundado; y ademas de la debilidad que en él se advierte, queriendo atribuirla á lo cálido y frio de los climas, nunca se da cumplida satisfaccion á la diversidad de contexturas y disparidad de las facciones, en lo que hay tanta disonancia como la que se percibe en los coloridos.

2 Los Indios son de un color que tira á roxo, y a fuerza de tostarse con el sol y con el viento, toman otro que obscurece; pero es necesario advertir, que lo frio de los temperamentos ni lo caluroso, no induce en esto variacion sensible; y así los Indios de la parte alta se equivocan con los de la baxa del Perú; y entre estos los del pais que llaman Valles con los de otros mas calurosos; sucediendo lo mismo á los de la parte Meridional desde los 40 grados hácia el Sur, y los de la Septentrional desde los 40 grados, y de allí para el Norte, los quales no se distinguen en el color de los que habitan hácia la Equinocial; de modo, que mezclados unos con otros no es fácil discernir qual sea de una parte, y qual de la otra; porque recayendo sobre el color propio el efecto que causa el sol, el ayre y el frio, vienen á quedar todos de un roxo obscuro, que es el general entre ellos, como se asentó. En la raza de Indios se distinguen ménos las diferencias que en las otras: como, por exemplo, entre los Negros hay unos belfos de nariz aplanada, y ojos cargados de carne, que comunmente se llaman Getudos, y en lugar de cabellos tienen lana. Otros, cuyo color es tan negro como el de aquellos, y las facciones son semejantes á los blancos, particularmente en boca, nariz y ojos, y el cabello es lácio, aunque grueso; hay algunos colorados, y otros de color claro, tirando al de los Mulatos. En los Indios se percibe poco la diferencia del color, y aunque en las facciones varian bastante, las que son propias 
de la raza son sensibles en todo; como es la frente muy pequeña y poblada de cabello hasta las extremidades, ó la medianía de las cejas, los ojos pequeños, la nariz delgada, pequeña y encorvada hácia el labio superior, el todo de la cara ancha, las orejas grandes, el cabello renegrido, lácio y grueso, las piernas bien hechas, los pies pequeños, y los cuerpos fornidos y dobles, el ser lampiños, pues solo quando llegan á viejos tienen alguna barba, pero nunca en las mexillas; y aunque tengan alguna discrepancia en esta contextura, conservan siempre el ayre de la raza, y no se equivocan con los Mulatos, que son los que les acercan algo en el color.

3 Visto un Indio de qualquier region, se puede decir que se han visto todos en quanto al color $y_{\text {; }}$ contextura; pero en quanto á corpulencia no es así, variando segun los parages. Los de la tierra alta del Perú son de mediana estatura : los de la baxa la tienen algo mayor, aunque la diferencia es poca. No así los de las partes Meridionales desde los 36 grados para el Sur, ni los de los Cayos en la parte de la Florida, ni los de la parte Septentrional desde los 30 grados para el Norte, en quanto hay conocido por el Misisipi, el Canadá, y hácia la parte de la Nueva España, que son de estatura alta, bien hechos y fornidos, cuya diferencia no puede atribuirse ni al frio ni al calor, mediante que en el Perú hay de uno y de otro, en tanto grado como en los paises de mucha latitud, ó en los que no la tienen. Poco ménos que con el color sucede por lo tocante á usos y costumbres, al carácter, genio, inclinaciones y propiedades, reparándose en algunas cosas tanta igualdad como sí los territorios mas distantes fuesen uno nismo. Todas las naciones de Indios han gustado mucho de pintarse los cuerpos de colorado, buscando para ello las tierras que dan este color; y la mina de Guancaveli- 
ca no tenia otro uso entre los del Perú, que servírse del cinabrio para este fin: los de la Luisiana, del Canadá, y los mas remotos hácia el Norte, propenden á pintarse con extremo, y no hay mejor mercancía para ellos que el bermellon. Parecerá particular, que siendo de naturaleza colorados usen tanto de este color; pero en esto no hacen mas que lo que se practica entre las naciones mas cultas de Europa, que siendo blancas usan varios ingredientes para hacer sobresalir mas la blancura. Los Indios civilizados del Perí no lo acostumbran ya, pero lo usaban ántes de la conquista; y entre las naciones que subsisten en su libertad no dexan de practicarlo. En las de la parte del Norte es general, y para ello se sirven, ademas del color roxo, que es el principal, de blanco, negro, azul y aun verde.

4 La obra de pintarse en los Indios de la Luísiana y en los que pueblan aquellos dilatados paises hácia el Norte, viene á ser como en las naciones cultas el vestirse y ponerse decentes para parecer. Llámanlo ellos mactacber, y es en lo que emplean sus talentos, practicándolo con la mayor prolixidad y delicadeza; en lo que se dexa conocer su paciencia, siendo la única cosa que hacen sin pereza, y para que están siempre prontos. Necesitan cinco ó seis horas, que es una mañana entera, para esta operacion; y la dama mas delicada y prolixa no hace tanto uso del espejo para tocarse como ellos : van aplicando los colores con tal arte, que se requiere tener destreza para hacerlo: por la. raiz de las pestañas, sobre los dos párpados, ponen dos líneas de color del grosor de un hilo: lo mismo executan en los labios, en las aberturas de las narices, y sobre las cejas: en las orejas tambien ponen haciendo las mismas vueltas que ellas tienen. El resto de la cara lo distribuyen en varias figuras, siendo el roxo el que sobresale, y los otros sirven para realzar10. 
DECIMOSEPTIMO.

10. Tambien parte del pescuezo entra en esta 255 ra, y de ordinario sobre las mexillas ponen galanubastante espesas de bermellon. Para inventar las figuras que han de hacer, y tirar las líneas con sutileza y perfeccion, necesitan del tiempo que se ha dicho; y como no sienıpre corresponden á la idea que se forman, sucede el borrarlas despues que están hechas para sobstituir otras que les quadren mejor á su modo de juzgar. Es tal la presuncion y el deleyte que tienen en esto, que despues de estar mactaches no sueltan el espejo de la mano, ni cesan de mirarse en él, recreándose con su propia figura: el resto del cuerpo queda á lo natural, y lo mismo la cabeza, sin ropa que les cubra la carne; siendo lo comun andar en cueros, y solo con lo que llaman tapa-rabo.

5 Los Indios gucrreros, que son como los Capitanes de valor y crédito, se distinguen de los otros en traer pintado el cuerpo en estampado, introduciendo los colores por el pellejo, que llaman piqueteado, por hacerse á fuerza de piquetes; y á proporcion de las proezas se extiende este modo de pintura; los unos no traen mas que los brazos, otros aumentan las piernas, en otros se extiende á los muslos, y en otros desde la cintura arriba, que son los principales en la guerra: de este modo, á medida que las acciones y la reputacion van creciendo, lo va tambien el estampado.

6 Estos guerreros usan tambien de plumages, que ponen en la cabeza en forma de garzota, en los brazos y en las piernas, mas arriba de los tobillos, al modo de brazaletes, siendo asimismo distintivo de las armas y señal de valor; y asi los que no son guerreros no los traen.

7 La propension al ocio y á la desidia es la misma en los de la Luisiana y el Canadá que en los del Perú y partes meridionales de la América, civilizados 
dos ó gentilus; y los únicos exercicios en que se ocu. pan los que subsisten en su libertad, es la caza y la pesca, lo qual sucede asimismo a las naciones que están vecinas al Paraguay en las Pampas de Buenos Ayres: las mugeres son las que tienen el cuidado de hacer unos cortos sembrados de maiz, y de algunas calabazas, las que lo muelen para prepararlo del modo. que lo usan, y las que disponen las bebidas que acostumbran, cuidando al mismo tiempo de los hijos, porque en esto no se embarazan los padres. Las Indias reducidas de toda ld América Meridional usan lo que llaman el urcu, que significa el cerro, y estirarse el cabello desde la mitad de la cabeza sobre la frente, y, cortarlo todo al rededor desde las orejas, por encima de los ojos, tapando con él la frente y cejas. Esto mismo practican las del Norte; unas y otras atan el resto del pelo atrás, haciendo coleta, y son tan iguales en ello, como si se hubiesen modelado las unas por las otras. Esta uniformidad hace ver venirles la moda desde la primera raza en que empezáron á esparcirse por aquella inmensidad de paises.

8 No sucede lo mismo con los Indios en este particular; los del Perú en la parte alta traen el cabello largo y tendido, sin cogerlo, siendo esto un género de galanura; los de la baxa muchos lo cortan, haciéndolo así por causa de los calores, é imitando á los blancos; los de la Luisiana se lo arrancan de raiz desde media mollera adelante, para hacer la frente grande, habiéndosela dado muy pequeña la naturaleza, y el resto de él lo cortan corto : esto lo hacen para que en la guerra no tengan los contrarios de donde asirlos, ni facilidad para arrancarles las cabelleras quando caen en su, poder, porque es uso entre ellos llevar los vencedores por triunfo las cabelleras de los vencidos. El modo de sacarlas es cruel : los asen por los cabellos qua ndo son Européos, que los acos- 
DECI TROSEPTIMO

tumbran largos, y cortándoles el pellejo de la frente al rededor meten los dedos por entre él y el hueso; $y$ arrancan de quajo todo el pellejo de la cabeza, y el cabello que está con él: sin cmbargo de ser tan inhumana y dolorosa esta operacion, viven algunos que han pasado por ella: quando no tienen cabellos los vencidos es mas dificil la tal obra, faltando de donde asirlos para tenerlos sujetos.

9 Generalmente es inhumana esta nacion, y se observa to mismo en los del Perú, civilizados ó libres, que con los de la Luisiana, diferencíándose, en que la circurstancia de estar civilizados los unos, y sujetos á leyes y gobierno, no pueden practicar su inclinacion en los racionales; pero con los animales se les ven hacer cosas que no dexan duda en ella. Su gusto en las fiestas de toros es llamarlos con 6 ú 8 lanzones, guarnecidos de rejones anchos, y clavárselos á la embestida á un tiempo, cada uno por donde puede, bastando esto para que sin mas diligencia cayga el aninal en tierra: inmediatamente acuden á cortarle el hocico, rabo, y varios pedazos de carne de los muslos, y los comen antes que acabe de morir; para qualquicr cosa que sea de crueldad se les encuentra dispuestos, reconociéndose en la alegría que muestran t ner complacencia de ello. De esto se puede cole ir, que si viviesen en toda su libertad como los de la Luisiana, Florida, y los de las partes mas mericionales, harian con los racionales lo mismo. Lo mas notable en estos casos es executar las crueldades á sangre fria, sin manifestar cólera, ni tener en que fundarla, al modo que hicieran qualquicr otra obra que no participase de inhumanidad.

ro La particularidad de ser lampiños, y no tener bello en parte alguna del cuerpo, es general en toda la raza, desde las partes septentrionales á KK

las 
las meridionales, y en esto se distinguen de las demas gentes.

I I Tienen el pellejo grueso, la carnadura recia, y ménos sensible que los de las otras partes del mundo; y entre varios exemplares que se pudieran referir, y lo confirman, será bueno el de la operasion de la piedra: ha sucedido en esta tardarse 27 minutos en extraerla á un Indio, sin dexar de manipular en él, quando lo regular es de 3 á 5 , porque estaba adherente, y al tiempo de quererla tirar se escapaba de la tenaza: fuéron muchas las veces que el operario la introduxo y salía sin ella, en cuyo tiempo no se le notáron los grandes estremecimientos y sensibilidad que regularmente causa el dolor, ni mas que un quejido lento que de tiempo en tiempo daba, al modo que quando se siente alguna leve incomodidad. Por último salió la piedra al cabo de repetidas diligencias, y á los dos dias clamaba el paciente porque le diesen de comer, dexando la cama ántes de los 8 dias sin dolerle nada, aunque la abertura no estaba del todo cerrada. Otro tanto les sucede en fracturas de hueso, en heridas, y los demás accidentes, notándose que con facilidad curan, y que no demuestran tanto dolor como las otras gentes. Reconocidos los cráneos que se sacan de lis sepulturas antiguas, se ve tener mas grosor que lo regular, siendo de 6 á 7 líneas; lo mismo se repara en el pellejo, manifestándolo así las operaciones de cirugía, y los esqueletos que se sacan de los sepulcros. De esto se infiere ser en ellos la organizacion mas tosca y de mayor resistencia; por lo qual es ménos sensible. Lo acredita tambien la resistencia con que sobrellevan las miserias y las intempcrics. Los de la parte alta del Perú, que se exercitan en ser ganaderos, habitan en las Punas mas rígidas, donde el frio y la nieve son quasi con- 
tinuos; y siendo muy poca la ropa que usan, se acomodan á tales destemples sin molestia, ni experimentar los efectos que causan en las personas de contextura mas delicada. Mucho puede contribuir el hábito, pero este no les libertaria del todo si la disposicion de los poros y el grosor del pellejo no ayudase. Los de la parte del Norte, semejantes á aquellos, resisten los grandes frios y hielos del invierno, sin dexar de ir á cazar, y no usan ropa con que abrigarse; porque aunque se ponen sobre las espaldas una manta de lana, que no ciñe al cuerpo, ó en su lugar alguna piel de animal, mas parece que lo hacen por gala que para resguardo; porque en lo fuerte de los calores la traen igualmente, quando las otras gentes blancas y negras no pueden sufrir ni aun las cosas mas delgadas de lino ó seda; y quando están cazando no la acostumbran para hallarse mas desembarazados, y llevar ménos estorbos al penetrar por aquellos bosques llenos de ramazones y de espinas; siendo de opinion, que estas resbalan sobre el pellejo, y sobre cosa de ro. pa hacen presa.

12 En todos tiempos andan con las cabezas desnudas, sin ponerse cosa alguna que los resguarde de la impresion de los rayos del sol ni del efecto de los hielos, y no se ve que padezcan de las incomodidades que causan, ni en la Luisiana de los violentos efectos del sol en verano, que matan prontamente á los de otras razas. La costumbre y' el hábito desde pequeño contribuyen sin duda en mucha parte, y estas tienen mayor vigor quando recaen en complexînes fuertes, que de suyo son poco sensibles. En la América Meridional se diferencian los Indios en los trages modernos, no siendo general uno mismo. Los del reyno de Quito conservan el que acostumbraban en tiempo de sus Reyes: en la $\mathrm{Kk}_{2}$ par- 
parte de Valles, y tierra alta del Perú, visten en parte á la Española, y en lugar de sombreros se sirven de monteras de paño muy pesadas y dobles, sin que les molesten quando van á los parages calientes, ni les hagan falta en los mas frios quando no las tienen: no usándolas todos con igual precision, andan desnudos de piernas y pies, y lo mas que suelen usar es alpargatas de pellejo de buey, que humedecidas despiden un olor muy malo: estas no se las quitan de los pies para dormir, ni para secarlas, manteniéndolas hasta que se rompen, y es una de las señales de su desaseo, y de no conocer fastidio á las cosas mas impuras.

I 3 Es general en esta gente la propension á la embriaguez, y para ello prefieren siempre los licores mas fuertes. Los del Perú usaban de la chicha hasta de pocos años á esta parte, que por la utilidad de los dueños de haciendas en la parte baxa, donde se crian viñas, y principalmente en los Valles de Ica, Pisco y Nasca se ha introducido el aguardiente, con el qual se aniquilan visiblemente. Igual inclinacion se nota en las muchas naciones que pueblan la América Septentrional desde la Florida y el Misisipi, hasta los parages descubiertos mas al Norte, á quienes los Ingleses de la Nueva Inglaterra por una parte, y por otra los Franceses de la Luisiana, y los que habitaban en el Canadá, los han habituado á esta bebida, sicndo el medio de que se vayan exterminando; y as se ha reconocido haberse disminuido sensiblemente cada nacion.

I La grande aficion que conservan al ocio yá la floxera les induce á ser extremosos en el uso de las bebidas que embriagan; siendo tal el desatino que tienen por ellas, que lo atropellan todo, arrastrando por quantos peligros pueden oponérseles, por saciar esta desenfrenada pasion. En la Luisiana 
se ha visto, no una sola vez, el Indio de mayor confianza, y al parecer de mejor razon, matar á su amo alevosamente acompañándole ála caza, ó yendo de viage, solo con el fin de robarle una limeta de aguardiente que le habia notado, y esperar para hacer el golpe el instante en que estuviese dormido, beberse el aguardiente, y dexar la limeta vacía á cortos pasos del cadáver. En la parte alta del Perú se ve con freqüiencia amanecer muertos en las calles de resulta de la embriaguez, quando perdido el sentido se quedan á dormir en ella, y el hielo los enfria; sin que estos exemplares lastimosos y repetidos les intimiden, ni las amonestaciones continuas que se les hacen les persuadan para contenerse, ó para valerse de alguna precaucion que les liberte del peligro. En Quito era costumbre no beber las Indias, y acompañar á los maridos para recogerlos quando no pudiesen, á fuerza de embriagados, con sus cuerpos. En el Perú beben las mugeres al igual de los maridos; se privan con ellos, y no pueden socorrerse uno á otro; pero lo que es mas particul r en este exceso es, que las madres incitan á los hijos desde muy tiernos del pecho, dándoles de lo mismo que ellas beben, y ántes de dispertar á las luces del conocimiento los acostumbran á la embriaguez.

I5 Les sucede con este vicio lo que es regular en todos, que quando empiezan á beber no tiene término el exceso, continuando hasta que enteramente caen, y quedan privados de sentido; y aunque se procure separarlos, fuera de lo mucho que lo resisten, vuelven á él llamados del frenesí dè la pasion. Son en esto, como en las otras costumbres, hermanos legítimos los de unas partes con los de las otras, sin que las distancias mas dilatadas de los paises causen diferencia. En Guancavelica, con motivo de los muchos Indios que allí acuden para los trabajos de 
las minas, en Potosí, y en los otros minerales grandes, se toca mas que en otras partes la fuerza de este exceso: es el uso allí pagarles los Domingos lo que han trabajado en la semana á los que no son Mitayos, y á estos darles á cuenta la mitad, quedando el resto para satisfacérselo junto al tiempo de concluir la Mira. Este pagamento se concluye á las 4 ó 5 de la tarde por los mineros, é importa en Guancavelica cosa de ro,000 pesos; los 4000, á corta diferencia, se beben de aguardiente en el resto de la tarde y noche; originándose de aquí que los Lunes hasta la noche es poco lo que se trabaja, á causa de no estar los Indios para ello, y así no les que. da dinero para el gasto de la semana, y pagan el Domingo siguiente lo poco que consumen de alimento en el discurso de ella. Ha habido Indio que se ha bebido en aquellas cortas horas el importe de 7 . pesos, que vendrá á ser lo que cabe en doce, ó trece limetas, sin que de pronto le resulte mas daño que la embriaguez, siendo bastante prueba de su resistencia. La chicha les embriaga en fuerza de la gran cantidad; pero no les resultaban los daños que se ven con el aguardiente, cuyo uso deberia estar tan seriamente prohibido como si fuese veneno, mirando á la conservacion de aquellas gentes; y que quanto mas se disminuya, irán por precision en mayor descaecimiento en aquellos reynos, siendo ellos los que se exercitan en toda suerte de trabajos recios de minas, labranza de tierras, guardas de ganados, $y$ otros.

I6 Si es perjudicial la embriaguez con los Indios por la disminucion de la especie, y la falta que hace á la subsistencia de aquellos reynos, no lo son ménos por los desastres que acarrea de unos con otros, pues es ordinario dimanar alborotos, quimeras, y acabar en tragedias, que por no ser regular 
DECIMOSE PTIMO.

permitirles armas, no son de las mas lastimosas; pero no dexa de correr la sangre en las lastimaduras que se hacen con piedras ó con palos, y alguna vez con cuchillos; de suerte que el dia de Domingo, que debia ser solemnizado con la mayor reverencia y temor, se ven las poblaciones llenas de gentes sin sentido, unos con las caras ensangrentadas, otros con las cabezas rotas, otros lastimados en el cuerpo, y por este término con reliquias de la privacion, hasta que rendidos se tiran por las calles á templar con el sueño las furias de los vapores.

17. Las muertes que los Indios del Norte executan en Blancos, ó Negros, ó con los de otras naciones de ellos mismos, aun estando en paz con ellas, no tienen otro orígen que el de la embriaguez, con la qual se enfurecen, y son muy ocasionados á hacer daño, no respetando, ni temiendo cosa alguna; y aun los mismos que les ministran la bebida es preciso que se precaucionen contra sus frenesíes, siendo esto en algun modo el principio que tienen las guerras que se suscitan entre varias naciones: pues siendo regla entre ellos satisfacer el agravio con igualdad en la pena, la cabeza del que mata es la que désvanece el sentimiento en la que se halla ofendida, y quando esto no se puede cumplir, ó hay resistencia en darla, pasa á ser la satisfaccion motivo de disension, debiendo tomar la venganza completa hasta la extension de la nacion, si fuese posible, de donde fué el agresor. En el trato y comercio que estas naciones admiten de los Europeos, es el principal renglon el aguardiente, sin el qual no apetecerian las otras cosas, por haberlos acostumbrado á cllo; y á este respecto los regalos que reciben han de comprehender parte de este licor, que es el que moviéndoles los espíritus al partido de la alianza, les incita tambien á la ira, y á cometer con ceguedad 
264

ENTRETENIMIENTO

las mas inhumanas atrocidades; llegando el aprecio á tanto, que le llaman leche de sus amigos, comparándolo con el primer nutrimento. Otro tanto sucede con las naciones Bárbaras del reyno de Chile, y con quantas mantienen trato con los Españoles en las partes meridionales del Perú: resultando de su pasion desmesurada, no conocer amistad donde falta el regalo de la bebida; y siendo forzoso condescender en ello, se procura minorar quanto es posible.

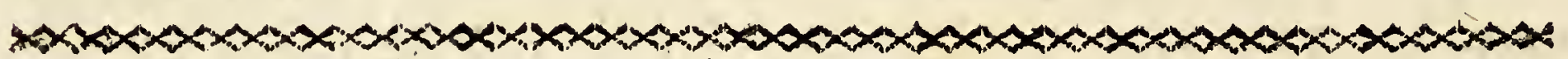

\section{ENTRETENIMIENTO XVIII.}

Continúanse las noticias del carácter y costumbres de los Indios, con la comparacion de unos con otros.

No son temibles los Indios por su valor, como lo son por sus alevosías y las astucias de que se valen para cometerlas. Vencedores por sorpresa, son inhumanos hasta el extremo, sin conocer piedad ni compasion, y esto lo hacen á sangre fria, deleytándose en la carnicería. Vencidos, son los mas cobardes y pusilánimes que se puedan ver: en el primer caso tienen complacencia en derramar la sangre de los infelices que han sorprehendido; y en el segundo se hacen inocentes, se humillan hasta el desprecio, disculpan su inconsiderado arrojo, y con las súplicas y los ruegos dan seguras pruebas de su pusilanimidad. Todas estas son propiedades que convienen con la cobardía y con la alevosía, que es el carácter propio de ellos: ó lo que refieren las Historias de la conquista sobre sus grandes acciones es en

u1 
un sentido figurado, ó el carácter de estas gentes no es ahora segun era entónces; pero lo que no tiene duda es, que las naciones de la parte septentrional subsisten en la misma libertad que siempre han tenido, sin haber sido sojuzgados por algun Príncipe extraño, y que viven segun su régimen y costumbres de toda la vida, sin que haya habido motivo para que muden de carácter; y en estos se ve lo mismo que sucede en los del Perú, y de toda la América Meridional, reducidos, y que nunca lo han estado.

2 No pueden, aunque se intente, atribuirse estas propiedades en los reducidos del Perú á las circunstancias de haber mudado de dueño, de hallarse dominados de una nacion extraña para ellos, de la sujecion en que están, ni á las demas causas que vienen con esta; atento que así como no han mudado de lengua, de usos, de propensiones, ni de costum bres, no es regular que mudasen de carácter, mayormente quando se ve no haber entrado despues de los años que van pasados de la conquista en las de la Nacion dominante: ademas, que la sujecion no es tal como se suele figurar la idea, porque ellos viven en sus pueblos con entera libertad, siendo gobernados por sus Curacas y Caciques, al modo que lo estaban ántes de ser conquistados; y lo que en: este asunto se advierte de particular es la igualdad que hay en los reducidos con los que nunca lo han sido, tanto de aquella misma parte, como de las mas distantes de ellas.

3 No habrá exemplar de que hombre á hombre, ó número igual de una parte y otra, hagan frente los Indios á otras gentes, sean Europeos, ó Negros Africanos, ni que los esperen aunque sean superiores: son, sin embargo de su poco brio, temibles, $y$ sucede con bastante freqüencia, que un corto número pone en derrota á otro crecido de tropa bien ar- 
reglada; pero esto es tomándola por sorpresa en paises cerrados de bosques, favorecidos de las ramazones que los encubran. De este modo atacan un cuerpo, haciéndole descarga donde se considera mas segura, y en el instante se trasponen, sin ser sentidos, ni dexar rastro del camino que llevan: esto basta rara que empiece el desórden en la que se ve insultada, ignorando qual sea el número de los contrarios, y las emboscadas que puedan tener dispuestas; por este método repiten de distintas partes los insultos, y haciendo sobre seguro las descargas, no hay tiro perdido: no encontrando objeto, los que las reciben para defenderse, al primer desórden sigue la consternacion y la périida de la empresa. Para este género de guerra son habilísimos, astutos $y_{\text {i }}$ sutiles; saben tener tanta espera, que para no perder el golpe, dan lugar á que se les logren las ventajas que premeditan, y la executan con quanta seguridad es neccsaria para salir con el intento: se ocultan entre los troncos de los árboles, como se dixo, y con las ramazones; y quando les filtan estos efugios se ponen tendidos sobre la tierra, y cosidos contra ella, de modo que no se perciben.

4 En el parage llamado Natcbées en la I.uisiana, que era una de las principales poblaciones que los Franceses tenian, practicáron en una noche el cruel asesinato de dar muerte á quantos le habitaban, executándolo sin embargo de la buena amistad y confianza con que vivian: en ello observáron tanto sigilo, que hasta despues de dado el golpe no se tuvo noticia de lo que pensaban; únicamente pudo escapar uno, favorecido de las sombras de la noche, siendo el que quedó para dar testimonio de la inhumanidad que exercitáron con los demas; y por una particular compasion de algunas Indias no padeció el mismo fatal destino todo el resto de aquel pais, 
DECIMOOCTAVO.

pais, que estubo sentenciado á ello. Las Indias eran las depositarias del secreto, y la conspiracion se habia hecho convocando la nacion Natchéca á las otras de aquellos territorios, hasta largas distancias, para que un determinado dia acometiesen á las poblaciones Francesas, cada una á la que estuviere mas inmediata, y no dexasen hombre á vida: el dia estaba señalado en un manoxito de varillas que les repartiéron á cada una, con la disposicion de arrojar una cada dia de los que se pasasen, desde el que se dispusiéron los manoxillos, para que quando no quedase mas que una, fuese este el señalado para la sorpresa general en lo mas silencioso de la noche. Repartidos estos manoxillos, quedó el que correspondia en Natchées, y la India que lo tenia á su cargo, ó por sí, ó consultando con otras, compadeciéndose del fatal golpe que habia de exterminar á los Franceses, quitó del manoxillo tres ó quatro varillas en un mismo dia, $\mathrm{y}^{\mathrm{k}}$ con esto vino á acortar el término para los de su nacion, que apuradas en los siguientes dias las restantes varillas, practicó el asesinato quando faltaban las mismas tres ó quatro varillas, que se habian quitado, á las otras naciones, y por esta razon no pulo ser á un tiempo en todas; lo que dió lugar á que descubriéndose la conjuracion se tomasen providencias para la defensa, y para cortarla el curso, sin cuya casualidad hubiera sido inevitable el premeditado intento.

5 De este modo destruyéron los Indios de la Provincia de Macas, en el reyno de Quito, la rica ciudad de Logroño, la poblacion de Guamboya, con su capital Sevilla del Oro, que eran muy pobladas, perdiéndose la memoria de los parages donde estuviéron, y de los que daban las crecidas cantidades de oro, por donde adquirió el nombre: en $\mathrm{Ll}_{2}$ 
el reyno de Chile, la Imperial, con otras de su depenciencia, for los Indios Araucos y Tucapeles: los pueblos de Misiones de los Chunchos, en la jurisciccion del Gobierno de Tarma: los del Dariel, en el reyno de Tierra-Firme; y otras varias que se han experimentado en distintos tiempos en aquellos paises, siendo iguales en el método de las convocatorias, en el disimulo con que guardan el sigilo, sin que falte por alguno de los convocados; y: aun en las horas que eligen para executar el golpe, no ménos que en la clase de crueldades que cometen, quitando la vida á sangre fria, y sin conocido motivo de sentimiento, á los varones de todas edades, y conservando las mugeres, como despojo. del triunfo alevoso, para servirse de ellas.

6 No se trata aquí de las inhumanidades que executan en tales ocasiones, y del secreto que guardan en ellas como cosa extraordinaria, pues estas mismas son regulares en iguales acaecimientos en todas las gentes: lo particular entre los Indios es la conformidad que guardan, sin que las distancias en que, viven causen variacion en el método y la inhumanidad con que lo executan; sin que pueda atribuirse á tenerles oprimidos, pues las naciones que pueblan los vastos territorios desde la Luisiana y Florida hácia el Norte, no han sido sojuzgadas, ni privadas de su libertad, para que pudiese atıibuirse á ello; y aunque son limitadísimos de entendimiento, y torpes en los asuntos en que se necesita obrar con refiexion, en los de esta especie, en que se mezcla la inhumanidad, la infidencia y el interés del pillage en los despojos de la accion, los de la Luisiana, y los de Chile, los de Quito, y los de Tarma, con todos los otros, son hábiles y expertos, como si hubiesen tomado las lecciones en una misma escuela; y como parte de 
ellas son tan cautos en la observancia del sigilo, que no flaquean con motivo alguno.

7 Aquella gente no cuenta los dias numerándolos, ni distingue los de la semana, siendo para ellos todos como uno mismo: solo conocen las lunaciones, por ser objeto visible, no gustando de que trabaje la memoria con semejante embarazo, y por esto quando deben hacer alguna convocatoria con otras naciones les envian un mensagero y un manoxillo de varillas con tantas de ellas, como dias han de pasar desde el que premeditan la cosa, hasta el que se debe executar, que es lo mismo que decir dentro de tantos dias.

8 Es preciso advertir, que el agravio particular de un solo individuo entre ellos, ó de una nacion, se hace causa comun, comprehendiendo aun á las mas distantes, y que para este caso no les detiene el pacto de la amistad recíproca en que se hallan ligados, con la que intentan ofender, ni el reconocimiento de los beneficios que reciben de ella, atropellando estos respetos, y con ellos la buena fe: acreditase con ello la poca seguridad que puede haber en sus palabras, siendo forzoso vivir en desconfianza y con cautela, pues no es seguridad la amistad para estar libres de sus conjuraciones imprevistas.

9 Acometen con resolucion y ferocidad á algun individuo que encuentran indefenso, por robarle lo que tiene y vestirse de sus despojos. Lo mismo hacen con astucia y prontitud en alguna casa retirada de poblado, asaltándola por las paredes con mucho sigilo, ó introduciéndose con silencio sin ser vistos, siendo la primera diligencia el asesinato de los que duermen; y estando asegurados en esta parte roban lo que encuentran; pero si perciben disposicion para resistirles, se retiran con el mismo silencio que emprendiéron, y. 


\section{0}

ENTRETENIMIENTO

vuelven à emboscaise hasta hallar mejor ocasion. Se observa en los de la parte del Norte, que quando se calientan con la bebida, y que se quiere incorporarlos con la tropa, como se practicaba en las guerras que ha habido entre Franceses é Ingleses; son arrestados, pero no subsisten mas que interin pasa el fervor de los vapores del licor, y que se ven bien sostenidos; pero faltando una de estas dos circunstancias, se separan para volver á su modo de emboscadas. A esto alude la frase que usan los Indios civilizados del Perú, que hablan algunas palabras mal pronunciadas en Español: quando se alborotan empiezan por beber bastante aguardiente, y á esto llaman animó, pronunciado largo, que es lo mismo que decir, tomar valor. Con ellos no dexan tambien de experimentar alborotos repentinos, juntándose muchos, y á pedradas acometen con intrepidez y gritería; pero con poca gente que se les opongan vuelven la espalda, se ponen en fuga, huyendo sin tino por distintos lados, para disimular haber tenido parte en el alboroto.

ro Por su ninguna fe, por su facilidad en alborotarse, y por la complacencia con que concurren á todo lo que mira á hacer daño, ha sido una de las providencias que se han dado la mas prudente y sabia para el gobierno de las Indias Españolas no consentirles armas á los que están reducidos $y$ subordinados, ni darles conocimiento de su manejo, tenerlos sujetos, y precisarlos á que trabajen en las cosas que se les ocupa, como son las Mitas de minas $\mathrm{y}$ de haciendas de labor; porque de no observarse así no habria seguridad de mantenerlos en obediencia, comu lo manifiestan los varios lenvantamientos ó alborotos, que con muy ligeros motivos suceden en las Provincias, los quales si llegáran á tomar cuerpo, serian temibles. Las naciones Francesa 
é Inglesa se han manejado en las partes del Norte de distinto modo. Les introduxéron armas de fuego, y les enseñáron á usarlas, con el fin de que hiciesen mas crecidas cacerías, para que fuese mas consicrable el comercio de las pieles, y con la máxima tambien de aumentar sus tropas quando las necesitasen, para emplearlas recíprocamente la una contra la otra; pero de aquí ha resultado haberlos armado y dispuesto contra sí, pues siempre que no les conceden quanto piden, vuelven las armas contra los mismos que se las han franqueado. Cometen correrias y violencias en sus establecimientos; les precisan á solicitar su amictad per mecio de regalos y gratificaciones, sin poder contar con su amistad; porque en la ocasion son de quien mas les da de pronto, olvidanilo contribuciones y beneficios pasados; $y$ for esto es una de las principales máximás de aquellas partes tenerlos gratos, no darles ni aun renotos motivos de queja, y quando la forman precurar con dones aplacarlos, aunque sean mal fundadis.

I I Esta gente tiene la propiedad de dormir poco, y de pasar lo mas de la noche en vela: sus funciones de alegria y regocijo, que son inseparables de la embriaguez, duran tanto de dia como ce noche : quando se sienten cansados indistintamente se tienden y duermen, y á la hora que despiertan vuelven á continuar, sucediéndoles lo mismo en qualquier tiempo; y así quando todo el mundo está entregado al descanso, ellos andan vagueando de un lado al otro, sin objeto determinado, ni serles impedimento el tener que trabajar despues en los destinos que les ha impuesto la sujecion. Los que subsisten en su libertad en las partes de Chile, Pampas de Buenos Ayres, y en los demas paises de Montaña, y los de todo el Norte desde la

Flo- 
272 ENTRETENIMIENTO

Florida en adelante, tienen esta misma costumbre, no obstante la precision de buscar el alimento en la caza ó en la pesca.

I2 Por lo que queda explicado se reconocerá ser la vida de estas gentes semejante á la que hacen los brutos, sin horas determinadas para las distribuciones, y que tambien les parecen en ser de poco sueño, manteniéndose en vela la mayor parte de las noches: lo mismo se advierte en el modo de descansar, ó de mantenerse quando no se hallan ocupados: los de los paises muy cálidos se tienden en las jamacas que ellos mismos fabrican, pero los demas lo hacen en el suelo unos entre otros, sin disrincion de sexôs ni de estados; de donde puede inferirse las conseqüencias que sobrevendrán, propias de una vida brutal.

I3 A la rusticidad y barbarie, de que respectivamente se hallan poseidos, se sigue la cortedad ó falta de nociones: ya se ha dicho no contar los dias, ni distinguir semanas. La luna quando la ven les indica el término de un tiempo, sin embarazarse en los dias que contiene: los frios en el invierno, y los calores en el verano, ó la alteracion de hielos y de nieves, les determinan el período de un año, pero sin ocupar la memoria en retener el número de lunaciones que contiene, mucho ménos las otras medidas mas pequeñas del tiempo: quasi no tienen idea de lo que es año; y exâminando á algunos, que manifiestan mucha vejez, de los mas civilizados del Perú, sobre la edad que tendrán, nunca se puede sacar de ellos mas noticia que la de los Gobernadores ó Caciques que han conocido, y aun así son imperfectas las que dan; sucediendo tambien que conservan la de los mas antiguos, y no se acuerdan de otros que ha habido posteriores, porque tal vez son lus acaecimientos particulares los que se los hacen 
DECIMOOCTAVO.

$2 \% 3$

tener presentes. Lo mismo sucede con los que se mantienen en su primitiva libertad, sin percibirse que pongan cuidado en mantener especies de lo fasado, ni en ampliar las ideas á lo sucesivo: únicamente se ocupa su imaginacion en lo presente, y de ello en lo que tienen mas inmediato. No sería esto notable si no se advirtiese ser igual entre los que reciben documento de cultura, y los que carecen de ella, pues los reducidos del Perú, que de continuo se están rozando con Españoles, que tienen Curas que quasi diariamente les doctrinan y les instruyen, que tratan con las gentes de todas clases sociablemente, son en este particular tan indiferentes y torpes como los que siempre han vivido en la primitiva barbarie entre las fieras, haciéndose mas notable á vista de los Negros de Africa, que llaman allí Bozales, porque estos con ménos instruccion, y quasi sin documentos, despues de haber estado allá algunos años, adquieren el conocimiento de numerar los dias, los años, y otras luces muy distintas que los Indios; de donde procede, que aun siendo esclavos se tienen por mas que ellos, y les miran con desprecio como incapaces, y sin discernimiento de racionalidad.

I4 Los del Perú, en tiempo de los Incas sus Señores naturales, conservaban memoria de los hechos notables, y tenian cierto modo de policía, que rem fieren sus Historias. Esta cultura la debian principalmente al cuidado de aquellos Soberanos y al régimen que entabláron con ellos, precisándolos á vivir con reglas de racionalidad, dando lugar á discurrirse haber sido aquellos Legisladores de alguna raza mas culta y civilizada que la de los demas Indios comunes, de la qual no se percibe conservarse algunos.

I5 Son por lo general de larga vida, aunque dificil de averiguar el número de sus años, por la $\mathrm{Mm}$ ras 
razon que va enunciada; pero hay dos señales, que manifiestan quando son de edad muy avanzada; la una las canas, y la otra las barbas: aquellas no empiezan á parecer hasta que están en 70 años ó cerca de ellos: estas otras hasta que pasan de 6o, y siempre son pocas; y así quando se ven del todo encanecidos, y que las pocas barbas lo están igualmente, se juzga que pasan de un siglo. Preguntándole á uno, cuyas señales indicaban ser de mucha vejez, su edad, respondió, que tendria mas de 20 años; y exâminándolo por otros medios, decia que su macbú le hablaba quando era niño de las cosas de los Incas, á cuyos Príncipes habia alcanzado; segun esta relacion, era preciso que entre los dos hubiesen compuesto 232 años á lo ménos: el machú venia á ser el abuelo; y este de quien se trata, en el año de 64 aparentaba mas de I20 años; porque fuera de tener blanca toda la cabeza y barba, estaba muy agoviado del cuerpo, pero sin indicios de impedimento ó achaque que le causase la edad. Esta larga vida, y la sanidad con que la mantienen, es conseqüiente á la falta de asuntos que ocupan sus imaginaciones; á la vida puramente animal que hacen, y á no tener que desear, ni que temer en sus interiores; á la organizacion ménos delicada y mas tosca ó basta que las otras gentes; pues si no se aniquilasen tanto con las guerras que subsisten entre si los Gentiles, que los Franceses llaman Salvages, originadás únicamente de la venganza, ni fuesen tan extremosos en el desórden de la embriaguez con las bebidas fuertes, sería una raza de gente que disfrutaria las conveniencias de la libertad y de la independencia con perfeccion, y estaria ménos expuesta á perecer temprano.

I6 Es costumbre de ciertas naciones de Indios del Perú abrirse las orejas todo al rededor por el pliegue 
DECIMOOCTAVO.

275

gue mas exterior, para hacerlas mayores, teniendo esto por galanura, lo qual se conserva hácia las partes del Marañon, en las que por alusion los llaman Orejones: otras acostumbran hacerse agujeros en las ternillas de las narices, en los labios, y en la barba, para poner en ellas unas varitas delgadas, como de una quarta de largo, al modo de las puas del puerco-espin. Esto mismo practican las naciones generalmente del Norte, y así están conformes en ello unos y otros, no dexando duda de haberse conservado en ellos estos usos desde los primeros pobladores de aquel mundo, y que su antigüedad viene de los mas remotos tiempos. Lo notable en este particular es, que guardando tanta uniformidad las naciones que habitan aquel Nuevo Mundo, á tan grandes distancias las unas de las otras, no se encuentra igual semejanza con los pueblos de las otras partes del Mundo antiguo, cuya circunstancia induce á concluir que desde los primeros hombres que se repartieron por aquellas tierras se han conservado los usos $\mathrm{y}$ costumbres sin variacion, y que las que tienen son coetáneas á su poblacion.

I7 Entre los Indios de las partes Septentrionales se nota introducida la costumbre de tomar otra muger quando la que tienen envejece, sin separar á esta de la casa, la que queda haciendo cuerpo con la familia, y sirve para cuidar de los pequeños sembrados, moler el maiz, y preparar á su moda la comida y la bebida, de suerte que viene á ser como la criada que sirve á los demas: la jóven acompaña al marido á la caza y á la pesca, y es la que carga las piezas que mara: cada una cuida de los hijos que la pertenecen, hasta que crecen y se separan de los padres. Quando salen á cazar quedan sus pueblos, ó rancherias al cuidado de las mugeres reformadas como por modo de descanso, no contemplándolas bas$\operatorname{Mm} 2$

tan- 
tantemente robustas para resistir las fatigas que son anexâs al exercicio.

I 8 Los Indios civilizados del Perú no tienen proporcion para hacer otro tanto, porque no se les permite, y se les reprehende con castigo qualquier desórden que toque en esto; pero hacen un equivalen$\mathbf{t} z$ en cambiarse las mugeres, y en tomar alguna otra soltera, dexando á la propia, sin que en ello tengan rubor ni cautela, siendo uno de los cuidados que tienen los Curas, los Corregidores, y aun los propios amos á quien sirven, aunque con poco fruto, por no ser ellos pundonorosos, ni hacerles la mayor impresion las amonestaciones ni consejos que se les dan. De esto se puede inferir, que si tuviesen la libertad que los otros, harian lo mismo que ellos. Las Indias reformadas no manifiestan sentimiento, conformándose sin repugnancia con lo que miran admitido por costumbre, que en ellos se reputa por ley.

19 Por lo tocante al modo y disposicion de sus alojamientos, se nota haber concurrido la necesidad, ayudada de la naturaleza, á darles reglas de edificar con sencillez para resguardo de los temporales en las horas y tiempos que lo requieren; y así se ve que las naciones, sin embargo de su barbarie y falta de civilidad, se hallan juntas, y tienen poblaciones á su moda, donde viven y hacen la principal residencia. Las casas de los Indios son en figura redonda, y hasta la altura de un hombre ó poco ménos; sube la pared derecha, despues cierran con la techumbre en forma piramidal, $y$ al rededor ponen por lo interior un tablado, que les sirve para tenderse sobre algunas pieles de los animales que cazan: en el centro hacen el fogaril, y la pieza no tiene mas abertura que la puerta, la qual es bien estrecha, y del alto preciso para entrar: el humo sale por ella $y$ 
DECIMOOCTAVO.

por entre las ramazones y hojas que hacen la techumbre: el material es en unas barro y piedra, en otras madera, cerradas las junturas con el barro en donde no hay de aquella.

20 Por la parte de adentro en la pared hacen unos nichos quadrilongos de un pie ó media vara de alto, y una quarta de ancho, al modo de los que se ven en los Palacios de los Incas en el Perú, que les sirven para poner las pocas cosas de que hacen uso. Cada familia tiene su casa ó choza dispuesta en la misma figura, siendo unas mas grandes que otras.

2 I En cada poblacion hay tambien una casa comun con tablados al rededor; esta es mucho mas grande que las particulares, en figura quadrada ó quadrilonga, y sirve para juntarse, y hacer sus concejos, en que tratan sobre el tiempo en que han. de salir á hacer caza ó pesca, los que han de ir en cada quadrilla, los parages á donde se han de distribuir, el tiempo que han de estar fuera para volverse á juntar, y el modo de hacer las correrías contra los extrangeros establecidos, y lo que han de practicar en cllas, que todos son asuntos interesantes. En esta se juntan para beber, y para celebrar sus festividades con danzas: sobre ella tienen el granero donde recogen el maiz y las calabazas que les ha dado la cosecha. Estos pueblos no guardan formalidad de calles ni de plazas, estando las casas sin órden, y de ordinario las hacen en las orillas de los rios. Aun todavía conservan los Indios civilizados del Perú el mismo modo de casas ó chozas, y el tener en cada pueblo una comun para hacer sus juntas, y tratar de sus negocios particulares, con la diferencia de los no reducidos; que los que lo están deben ceñirse á las cofradías y mayordomias, cuya invencion, quando es mode- 
rada, y no con el exceso que suele introducir el abuso, es muy buena para tenerlos sujetos y en obediencia, por ministrarles asuntos sobre que tratar, muy distante de los que les inspira la propension con que se inclinan á lo malo.

22 Los Jueces y Curas no obstante zelan mucho sobre estas juntas, evitando que traten en ellas cosas de alborotos, ú otras que puedan tener malas conseqüencias, y para ello tienen algunos de confianza que les dan noticia de lo que pasa; y quando se sospecha que se apartan de lo que les está permitido, van allá, y los separan, aplicando algun moderado castigo á los autores que inspiran en las otras malas ideas, siendo suficiente esta diligencia para desvanecer lo que premeditaban; pero quando se sospecha asunto de mayor gravedad, se procura contener con providencias y castigos de mas formalidad.

23 No es posible apartar esta nacion, despues de tantos años de reducidos, de sus antiguos usos y costumbres; y si se intentase resultarian mayores inconvenientes, pues de prohibirles en una parte pública las juntas, irian á tenerlas de noche á los parages retirados donde no fuese averiguable lo que discurrian en ellas.

$24 \mathrm{Ya}$ queda dicho y comprobado, que el trabajo que hacen los Indios en las minas del Perú no tiene cosa de perjudicial á su subsistencia; y el senalar Mitas para ellas, y que verdaderamente vayan con poca voluntad, es por repugnancia natural que tienen á todo género de trabajo, pues sí se dexase á su arbitrio nunca hicieran mas que los pequeños sembrados, al modo de los que practican los que subsisten sin sujecion.

25 Las Mitas, ó servicios de las haciendas, y guardería de ganados tampoco los disminuye quan- 
DECIMOOCTAVO.

do en el trato hay regularidad. La de los obrages sería lo mismo si en estos hubiese ménos rigor, y mas consideracion para el régimen de las tareas, y el jornal que se les hubiese de pagar, proporcionado á que pudiesen subsistir; pero mirando los dueños á su propia utilidad, y no al bien de los obreros, los tratan con poca humanidad, y de ello resulta la disminucion de los que entran: el remedio sería absolutamente quitárselas del todo, y que sus dueños empleasen gente libre de la mucha que abunda sin oficio ni ocupacion, Mestizos y de otras castas, prohibiéndose el perpetuo encierro para los que no estuviesen por órden de las Justicias, y juntamente que en ellos no se pudiese castigar corporalmente como se hace al arbitrio de los que los tienén á su cuidado, sino que en todo se gobernasen al modo que lo están las manufacturas en Europa. Ciertos castigos moderados son precisos en los Indios, porque sin ellos son irreducibles al cumplimiento de lo que se les dedica, predominando en ellos la propension á la ociosidad y al abandono; pero esto no se debiera permitir que se practicase por los amos á quienes sirven, que se exceden, y los maltratan en lugar de corregirlos, sino por la Justicia; de cuyo modo serian moderados, y en ellos harian mas impresion, sin quedarles el resentimiento de que sea la fuerza, y no la Justicia quien los castigue. De este modo hay suficiente experiencia, que enseña no ser necesaria, como pretende la vulgaridad, y la facultad despótica, para que cada uno sea árbitro de castigar sin limitacion á los que le sirven, siendo los instrumentos por donde aumentan sus riquezas. La total desidia y el abandono propio de su carácter obliga siempre á estar en continua batalla con ellos para que trabajen aun en aquellas cosas que son de propio provecho y beneficio 
suyo, como es en los sembrados comunes, y en las otras ocupaciones que les han de sufragar para vestirse : en ellos no obra la razon, ni se reconoce que las persuasiones muevan sus voluntades: uno y otro lo desprecia la inclinacion al ócio, y por esto se hace preciso que se les apremic con el castigo, y que se les den destinos á las Mitas, donde por necesidad vivan ocupados; pero aun de este modo la obra que hacen en el discurso de un dia, apenas corresponderá á la que un hombre regular acabará en la mitad del tiempo á lo sumo : esto nace, no de faltarles fuerzas, sino de aquella natural propension que los hace tardios en las operaciones, y lentos en lo que es trabajo. La caza y la pesca son los únicos exercicios entre los que viven en su primitivo estado; y esto es, lo uno porque la necesidad les obliga á tomar este empleo para mantenerse; y lo otro, porque son exercicios donde el discurso ni la precision trabajan mas de lo que apetece el gusto, y que no lo hacen de continuo, pues guardan las carnes para algunos dias, y en tanto que duran no se molestan, pasándolos en inaccion y entregados á la ociosidad.

26 Los conquistados que viven en obediencia hacen un sembrado comun, para lo qual se juntan todos los de la Parroquia, hombres, mugeres y muchachos, á lo que llaman tambien cbaco; y la obra que entre seis ú ocho hombres pudieran descansadamente acabar en el dia, la hacen ellos entre 60 ó 70 de todas edades y sexôs: llevan porcion de bebida, los tamboriles y flautas; $y$ al son de estos instrumentos trabajan, beben, comen y descansan á ratos, reduciéndose á un dia ó dos de diversion. Otro tanto practican quando recogen la cosecha, de cuyo modo la mayor parte de su producto queda consumida en estos dias; y si les faltasen tales atrac- 
DECIMOOCTAVO.

tivos de bebida y bayle, no concurririan.

27 Las personas que no tienen experiencia propia del carácter, propensiones, genios é inclinacion de los Indios, se persuaten á que el obligarles á que trabajen, el destinarlos á las minas, y darles otras ocupaciones, tiene visos de tiranía; y no es así, porque cada nacion y raza de gentes tiene sus leyes propias para gobernarse, dispuestas con conocimiento, que miran al fin de mantenerse baxo de un buen órden, como lo pide el bien comun de la sociedad: las de los Indios es preciso que sean muy diversas de todas las otras, así como sus inclinaciones y propiedades lo son. El inmoderado uso del aguardiente destruye mas Indios en un año que las minas en 50 , aun entrando en estas los extraordinarios accidentes de derrumbos que pueden sobrevenir. Los obrages los aniquilan por la inhumanidad con que se les trata, sin que hayan sido remedio las visitas que se practican de tiempo en tiempo, pues al cabo de tantos años no se reconoce enmienda. Estas dos cosas convendria que se reformasen por respecto á la humanidad, y á lo que debemos al próximo, y por conveniencia propia, para cuidar de la conservacion y aumento de una raza, que sin embargo de sus malas propiedades, vicios y desidia, es por la que se mantienen aquellos vastos dominios.

28 Se cree eista raza de gentes mas advertida $y$ : hábil que la Europea, siendo en ellos iguales los que pueblan las vastas campañas del Norte, con los del Perú civilizados ó montaraces, pareciéndoles que no hay gentes que puedan ser tan sabidas como ellos. Esta presuncion es hija de la malicia y pasion propia, y tambien de sus alcances; y quando sucede salirles al encuentro en alguno de los muchos engaños que premeditan, dicen que los Españoles ó $V i$ racochas quieren ya saber tanto como ellos. Los de $\mathrm{Nn}$ 
la Luisiana, y todas aquellas partes están persuadidos á que los Europeos no pueden igualarles en trascendencia, nacido de que su intento es siempre engañar sin que se perciba, y no ser engañados: así se sienten mucho, $y$ no perdonan el agravio quando se les falta á lo que se les promete; siendo así que no conocen buena fe ni legalidad, pues en lo mas urgente de las ocasiones faltan, disculpándose despues con pretextos que forxan al intento. Son solicitados para la paz, sin solicitarla ellos, y esto por libertarse de sus correrías: son temibles por la libertad y astucias de que se sirven para sorprehender: son despóticos, no reconociendo subordinacion á otro: son obsequiados con regalos, y ellos no los hacen, con el fin de que no cometan robos y asesinatos; y de aquí forman ellos el concepto de ser mas hábiles, sabios, y astutos que los que los solicitan, los temen, y los obsequian. La mentira y el engaño son tan propios en ellos como la embriaguez, y no se sonrojan quando se les descubre, buscando salida á los cargos, aunque no vengan al asunto. Sobre tan errados principios y débiles fundamentos se sostiene la creencia que aquellos Indios forman de sus ventajas y superioridad.

29 Quando tienen parlamentos los que viven en su libertad con las naciones Europeas, hacen unos discursos, á su parecer, pomposos, pero sin coordinacion ni método, hablando por figuras y comparaciones, que por lo regular tienen el fundamento en el sol, por su luz, por su calor, y por la carrera que hace, y esto lo acompañan con acciones y señas demostrativas: : son largos en los discursos, repitiendo muchas veces la misma cosa, y durarian el dia entero sin añadir nada á lo que dixéron al principio, si no se les procurase cortar: piensan mucho io que han de decir, y al cabo no producen mas que 
DECIMOOCTAVO.

que aquello que les parece propio á persuadir para que se les dé lo que desean. En este modo de perorar con presuncion fundan tambien su ciencia $y$ la habilidad con que sobresalen á las otras personas Europeas con quienes tratan, persuadiéndose á que los inducen á franquearles lo que desean con su grande eloqüencia. Los Indios reducidos son lo mismo en sus discursos, largos, cansados é importunos hasta el extremo, no teniendo término en ellos, de suerte que no se diferencian; y si el lenguage no fuese distinto, podria creerse que un Indio del Perú hablaba en el Norte, ó al contrario.

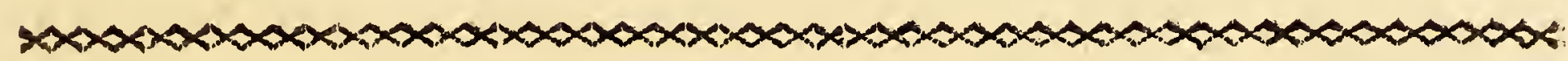

\section{ENTRETENIMIENTO XIX.}

Trátase de la religion de los Indios, de sus entierros, de su disminucion, $y$ de las castas de Mestizos.

I Isos Indios de la América Meridional, sujetos al Imperio de los Incas, tributaban cultos al sol, á quien erigiéron varios templos, y sus vestigios aun se conservan: los que no lo estuviéron, y que hasta los tiempos presentes permanecen incultos, sin sujecion, ni señas de civilidad, no se sabe que lo den al sol, ni á algun otro oljeto determinado; son supersticiosos por herencia; y segun las proporciones que les ofrece la casualidad, suelen tener veneracion á los objetos mas despreciables que se les ofrecen á la vista, aunque sin llegar á la formalidad de darles culto. Lo propio se observa con los de las partes del Norte en las muchas naciones que $\mathrm{Nn} 2$ ha- 
habitan sus dilatados territorios. Distintos Franceses han vivido entre estos por espacio de ro ó 12 años con el fin de aprender las lenguas; y segun Jas relaciones que hacen, no tienen ni aun ligeros indicios de rito, ni de cosa que se parezca á religion, asegurando no huberles descubierto ideas que den liz de tener conocimiento de una primera causa, ni sensaciones, de que dependen de un Criador que lo lizo todo; que para ellos son iguales todos los dias y las horas; que no se les advierte rezo, deprecacion, sacrificio, ni otro género de adoracion; y sierdo, ccmo va dicho, supersticiosos, sin atribuir los acaecimientos á una voluntad suprema, se dexa inferir, que sin sujecion á ley mas que la de la propia voluntad, ni aun siguen la natural en un método regular.

2. Este modo libre de vida, sin precepto ni ley contra la propension á las pasiones, ni freno que modere los impulsos de los vicios, ha causado mucho daño á varios de los Europeos establecidos en aquellos paises, que seducidos con el mal exemplo se hallan evtregados al mismo género de vida, no solo en lo perteneciente á la religion, sino tambien en las otras costumbres. Estos se hallan retirados por los campos con sus esclavos ó familiares, sin acordarse de dar al supremo Criador, á quien debemos el ser, y quanto nos concede, el tributo justo de las gracias que el reconocimiento y la obligacion dete ofrecerle.

3 Los Indios civilizados del Perú conociéron des de el ticmpo de los Incas una primera causa; y aunque sus ton plos estaban dedicados al sol, y le dabi n cultr, no dexírco por esto de tener alguna idea de que hibia otra, que era mas poderosa, sin tener necesidad de girar continuamente para dar ser y vidáá las cosas. Estos corsagráron al sol sus ofren. das, 
das, como deidad mas perceptible á los sentidos, atribuyéndole los teneficios, que por medio de su calor y luz recibe la tierra; y esta fué doctrina que les enseñáron sus Soberanos, y á que no alcanzáron otras naciones de Indios, que no estaban tan civilizados.

4 Estos Indíos reducidos del Perú tienen ciertos parages conocidos, que de ordinario están en lo alto de los cerros, siendo los que llaman Mocbaderos: la vulgaridad pretende ser á donde concurren á idolatrar; con este motivo dicen que llaman al Diablo, y que tienen largas y freqüentes conversaciones con él. En estos lugares se ven montoncitos de piedras puestas cerca de donde pasa el camino, que son hechos por los Indios, pues cada uno de los que suelen concurrir quando pasa por ellos tiene cuidado de llevar en la mano una piedra, y colocarla en el monton que le pertenece, haciendo así como ofrenda en esta especie de supersticion que conservan: en lo antiguo practicaban esto los Gentiles con su Dios Mercurio, colocado regularmente en las encrucijadas de los caminos. La palabra Mocbadero puede venir de mucbar, que significa besar.

5 Han participado todas las naciones de la tierIa de la costumbre de honrar los cadáveres de los difuntos, y en esto les han imitado los Indios, manifestando así las buacas en donde se enterraban, y juntamente la circunstancia de tener lugares determinados para ello. Semejantes en todo á las del reyno de Quito y las del Perú se encuentran en la Luisiana: dos de ellas están como roo leguas mas arriba del Nuevo Orleans, en el camino que va de los Opeluzas á los Natchitochas, en una habitacion que llaman de Richard, vecino de la Punta Cortada: la figura á modo de tumba ovalada, el tamaño y la positura en un llano, próximas á las casas de la habi- 
tacion, no dexan duda de ser sepulcros como aquellos, indicándose haber sido dispuestos para algunos Indios de la mayor consideracion; pues para llegar á formarlos necesitaban de mucha gente que concurriese á mudar la tierra de donde la sacaban para ponerla allí y hacer cerros bastante abultados; siendo tambien particular en aquel parage, por no estar en uso entre los Indios de aquellas naciones enterrarse de este modo, formando semejante género de monumentos para la posteridad.

6 Lo que hacen es formar en alto una especie de tumba con cañas puestas unas contra otras, y en ella colocan el cadáver. Estas las hacen hácia uno de los lados exteriores de la poblacion, y la altura que les dan del suelo es como dos varas; tienen de largo poco mas de lo que ocupa el cadáver. Esta tưmba está sobre unos pilares de madera; su ancho es una vara, con corta diferencia, y otro tanto de alto, desde el extremo de los pilares: con el difunto ponen cosas comestibles, como mazorcas de maiz, y las composiciones que hacen de él; por la parte de afuera, en el pilar que corresponde á la medianía de la tumba, por el lado de la cabeza, cuelgan algunas cosas de las que fuéron del uso del difunto, y principalmente manojos de cabellos sueltos sin trenzar, que serán sin duda de las mugeres que viven al tiempo del fallecimiento del marido, en señal del sentimiento de haberlo perdido, y se repara ser el uno de los manojos entero de una cabellera cortada por el tronco ó atadero, y los otros solo mechones delgados, indicando el mas grueso ser el ofrecimiento que le hace la muger última, y los otros de las que ya estaban reformadas; y así no se ven mas que dos ó tres de estos mechones. Allí dexan los cadáveres en sus tumbas hasta que el tiempo los consuma: en los principios no pueden dexar de causar mucha in- 


\section{DECIMONONO.}

feccion, traspirando el mal olor por ëntre las cañas, á ménos de que con la resina del pino ó de los cipreses los embalsamen para moderarlo. No se sabe con firmeza qué es lo que hacen con los huesos despues que quedan separados de la otras partes que se consumen; pero es natural que los que. men, para no dexarlos expuestos á que rueden sobre la tierra.

7 Reconócese en esto que siguen la costumbre general de todas las naciones desde los tiempos mas remotos, que guardan á los cadáveres de sus mayores, ó allegados cierta veneracion, preservándolos de que fuesen pasto de los animales y aun de la tierra, no acostumbrando enterrarlos, así como se observó en varias naciones de las mas antiguas; y los Egipcios principalmente los preparaban contra la corrupcion bálsamos y resinas, envolviéndolos con distintas bandas, y despues los colocaban en los nichos ó sepulcros que hacian, adequados para su conservacion. Tambien se dexa percibir en la circunstancia de ponerles comestibles, sea por el fin que se quisiere interpretar, que conocen no morir el espíritu con el cuerpo, y que tienen idea de la inmortalidad del alma; porque de no ser así no tendria objeto la ceremonia de acompañarlos con tales cosas. Quál sea el modo en que ellos lo conciben no es facil de averiguar, por ser en sus explicaciones sobre este particular limitadísimos y confusos.

8 En algunos parages de la parte baxa del Perü, y principalmente en los pueblos que habia en los $\mathrm{Va}$ lles de las Capillas y sus contiguos, se encuentra otra suerte de entierros diferente de los de la Luisiana. Estos están en las propias casas, y cada uno tenia el suyo ámanera de panteon: para ello destinaban una de las piezas, cuya capacidad, aunque variaba á proporcion de la voluntad ó representa- 
cion de los dieños, lo regular era tener de 4 á 6 varas en quadro: en el uno de sus ángulos correspondia el lugar sepulcral subterráneo, con tres varas de largo, 2 de ancho, y de $I \frac{1}{2}$ á 2 de profundo, dándoles la figura oval. Las paredes de estos panteones, que aun se conservan, eran de piedra de mampostería y barro: su techo lo disponian con troncos de árboles sin labrar, que servian de vigas, $y$ por encima de estas acababan de cerrar con caña brava y tierra, haciendo suclo firme, que es el que sirve de techo al panteon ó sepulcro. Esta pieza parece que no tenia otro uso: la puerta por donde se entraba en ella solo tiene de alto tres quartas, y de ancho dos tercias; siendo por su estrechez bien incómoda para entrar y salir; y aunque generalmente las otras de las mismas casas son pequeñas, llega su altura á una vara, y el ancho entre media y dos tercias. En su interior se observan varios nichos ó alacenas, semejantes á las que se han dicho hablando de las casas de los Indios de la Luisiana, cuyo uso es comun en las del Perú; pero en las piezas destinadas para sepulcro no las hay, como no necesarias allí.

9 Es bastante crecido el número de calaveras que se encuentran en cada uno de estos sepulcros, como de 30 á 40 ; unas de personas grandes, y otras de pequeñas, hallándose allí el resto de los esqueletos: por este número puede conjeturarse el de la antigüedad de los pueblos, mediante que cada matrimonio tenia su casa, y en cada una de estas habia su entierro; y así suponiendo la familia de 6 personas, y que de estas muriesen 4 en el discurso de cada 25 años, vendrian á ser 250 años, y esta la antigüedad de aquellos pueblos ántes de la conquista. Los Incas, que se sabe haber reynado hasta el último Huascar, en cuyo tiempo terminó su imperio, fuéron I $3 ; y$ excluyen- 
do á este, vienen á corresponder los 250 años, entre los I 2 que hubo, á 2 I años de reynado unos con otros, que es un tiempo algo corto; pero se debe suponer, que aquellos pueblos no se civilizáron desde el tiempo del primer Inca, y que sus entierros y poblaciones tomarian toda su formalidad despues que fuéron juzgados é instruidos por ellos.

ro En los sepulcros se encuentran los vestuarios que usaban, y eran blancos, de algodon, texidos al modo que ahora lo hacen, con algunas labores y colores diversos; pero están tan consumidos con el tiempo, que al tocarles se deshacen como si fueran de yesca. Tambien se encuentra lana de alpaca; y no viéndose la osamenta de este animal, se infiere pondrian con los cadáveres algunas pieles de él, y es regular que fuesen las mismas que en vida le servian para dormir; y de todo se deduce la uniformidad, ó diferencia que en quanto á esto observáron las varias naciones de Indios esparcidas por aquellos vastos paises.

I I Es opinion por aquellas partes bastante cundida, que ciertas naciones de Indios mas resueltos, ó de mayor corage que las otras, al ver sojuzgados aquellos paises por una gente extraña, tomáron el desesperado partido de enterrarse vivas con sus familias, huyendo del trance duro de sujetárseles quando no les quedaban esperanzas de defender la libertad: aunque esto fuese así, y que los de aquellos Valles se señalasen en esta resolucion, nunca se opone á que fuese costumbre en ellos tener los sepulcros dentro de sus mismas casas, como lo manifiesta lo que se ve en ellas, y la solidez con que están hechas, el no encontrársele otro destino, y el no faltar en ninguno de los muchos pueblos que habia por allí, y acaso la circunstancia de tener á la mano el lugar donde enteramente pudo moverles á tomar esta bárbara reso- 
lucion : para lo qual era preciso que en cada pueblo quedaran algunos que cerrasen los panteones, formando los terraplenes de los suelos en la sala que está sobre ellos en el modo que se encuentran.

I2 Los Indios de la parte del Norte acostumbran el calumó, que es una pipa, cuya canalilla tiene como una vara de largo, y de una misma chupan el tabaco quantos están en la compañía. Este calamó sirve de cumplido ó saludo entre ellos, como entre los Européos el brindarse con el vino. El uso del tabaco es allí bastantemente moderado. Entre los del Perú no se nota introducido, principalmente en los de la parte alta; y en los de la baxa en pocas partes, y en estos no de continuo : en que es digno de advertir, que siendo este fruto propio de aquellas partes, no sea general, ni muy freqüente su admision entre los naturales de ellas; y que en Europa se haya hecho tan comun y necesario, que forma al presente uno de los mas quantiosos ramos de las rentas de los Príncipes, y el mas seguro, por el gran consumo que de él hay. Los Indios que lo usaban era únicamente en humo; pero en Europa lo gastan en humo, en polvo y mascado, lo que igualmente conduce á que su expendio sea tan quantioso como á todos es constante.

I5 Los Indius del Norte de la América toman el tabaco de humo en las pipas largas que se ha dicho, y estas están engalanadas con labores de varios colores y colgados de plumas diferentes, cuya moda es la misma que acostumbran los Orientales, que obsequian á las personas que los visitan, presentándoles pipa para que fumen, y café ú otras bebidas; y así sin haberse comunicado unas naciones con otras, convienen entre sí, siendo de las partes mas remctas de la tierra: lo qual arguye, así por el uso como por el modo, haber tenido principio en un mismo tiempo. Las pipas, en la parte donde se pone el tabaco,

no 
DECIMONONO.

no son tampoco parecidas á las que usan los Européos, diferenciándose en la figura, así como lo son en la caña.

I4 No puede juzgarse que el uso del tabaco en humo vino á los Européos de las Indias Occidentales, porque siendo muy antiguo en el Oriente, era preciso que se comunicase de allí desde que hubo comercio por tierra de aquellas partes con el Mediterráneo, el qual hacian los Venecianos, ántes que los Portugueses descubriesen el paso por el Cabo de Buena Esperanza en I4\$7; pero lo que no admite duda es, que despues del descubrimiento de ellas se fué haciendo general hasta el término en que al presente se ve, y que desde entónces empezáron á variarse los métodos de usarlo, advirtiendo los que hay de componerlo; y así esta moda y el uso del chocolate, han venido del Occidente al Oriente, aumeñtándose con ellas las cosas precisas en el uso de la vida.

is Es cosa constante irse disminuyendo por todas partes el número de los Indios, bien sea por los estragos formidables que hacen las viruelas, bien por el uso de las bebidas fuertes y su inmoderacion incapaz de contenerse, bien por la repugnancia que les causa verse sujetos á naciones extrañas, y precisados á trabajar contra su inclinacion, ó por otras causas ménos visibles, aunque son bastantes las antecedentes. En las islas de Cuba, Santo Domingo, Jamayca, y las demas de aquella parte, sucede en este particular lo mismo que con el oro y la plata, que puede dudarse si los ha habido ántes de la conquista, ó á lo ménos si cran con la abundancia que se halláron, segun las pocas señales que subsisten de ellos. En la isla de la Puna, que está en la embocadura del rio de Guayaquil, y en todas las islas de la costa de Panamá, han faltado tambien los Indios; y lo mismo se observa en los varios pueblos que habia en las ca$\mathrm{Oo}_{2}$

be- 
beceras de la tierra baxa del Perú, donde empieza á subirse á la alta, en los Valles de las Capillas, el Tapara, Luna Guana, y otros diversos. Los vestigios que subsisten de los muchos que habia en tiempo de la Gentilidad, indican lo muy poblado de Indios que eran, pues cada quarto de legua, ó cada media legua se encuentra uno con sus casas y calles, dispuestas en toda forma, sin faltarles mas que las techumbres, $y$ al presente están despoblados. Las naciones comarcanas a las colonias Européas de la Luisiana, y las que lo están en la parte de la Nueva Inglaterra, se ven tan disminuidas, que se componen de doce ó quince familias cada una, siendo así que quando se empezáron á establecer allí los Européos eran crecidas; y sensiblemente se ve su disminucion en el término de pocos años; dexándose comprehender que en breve se hallarán enteramente extinguidas como las anteriores. En la parte alta no es tan considerable la disminucion, aunque no dexa de reconocerse bastante, particularmente en los pueblos que hacian cabeza de partido, y eran la residencia de los Curacas.

I6 Al paso que se extingue la raza de Indios en aquellas tierras, se pueblan estas de Européos, y de las castas que dimanan de las Africanas; bien que los Negros en su primer grado no subsisten á proporcion del quantioso número que se ha introducido de ellos, procedido sin duda como en los Indios de la sujecion que se les impone al trabajo contra la vida holgazana que ellos usan en sus tierras. En cierto modo parece que el empeño de los hombres y su ocupacion es transferir las gentes de las dos partes del mundo antiguo á la poblacion del nuevo, al paso que las cosas de este, y principalmente la plata y el oro, por un órden contrario, lo sacan de alli para depositarlo en el lodo de la tierra. Por esté término, considerado lo que se han mudado aquellos paises en los primeros

tres 
DECIMONONO.

tres siglos despues de su descubrimiento y conquista, se puede suponer, que en el discurso de otros tantos serán muy pocos los restos de Indios civilizados que subsistan, y que con la confusion de mezclas de castas Européa, Africana é India, vendrán á poblarse enteramente de una raza mixta que participará de todas, sin ser perfectamente de ninguna de las primitivas. Aquel mundo, nuevo á la verdad para las gentes que no lo conocian, podrá serlo tambien en sus pobladores respecto de las otras partes.

17 Los vecindarios de los pueblos del Perú se componen en gran parte de Mestizos, que son dimanados de la generacion de Blancos é Indios, cuyas razas van despues haciendo por grados otras distintas. En la parte baxa hay igualmente con alguna abundancia la de Zambos, que procede de la mezcla de Indios con Negrós: en la alta son pocos los de esta especie, por no ser muchos los Negros que van á ella, á causa de no permitirlo el clima por su mucha frialdad. La de Mestizos proviene en lo general de la procreacion de Indias con Blancos fuera de matrimonio, ó de Mestizos, siendo raros los que se ven de Indios con gente blanca; porque así como lo primero se tiene por distintivo apreciable de la calidad;, lo segundo es despreciable y vergonzoso, cuya recomendacion se imprime en unos y en otros, con la prerogativa que los de Blancos en Indias están fuera de la obligacion de pagar tributos, no sucediendo lo mismo con los de Indios y Blancas, que siguen la condicion de los padres. Esta exêncion favorece las generaciones mixtas, dimanando de ello una de las causas de acrecentarse las razas de Mixtos, y disminuirse la de Indios puros; porque es muy raro, y se tiene á cosa vergonzosa y despreciable aliarse de nuevo las Mestizas con ellos, ó al contrario.

I8 Lo mismo sucede con la raza de Zambos, aunque 


\section{4}

ENTRETENIMIENTO

que en el primer grado no es tan comun la exêncion de tributos; bien que siendo una generacion que se equivoca por el color con los Mulatos, no es muy corriente estar sujetos á ellos, y siempre al segundo grado están exêntos, porque no se mezclan tampoco con los Indios. De ello se origina ser abundantes las generaciones que resultan de Indias, quanto mayor es la disminucion de los Indios puros, que segun su importancia para toda suerte de trabajos en aquellos. reynos, recomiendan la aplicacion de todos los medios conducentes á que se mantuviesen á lo ménos, ya que no fuese posible que se acrecentasen. Esta ha sido una de las principales políticas del Gobierno; pero la experiencia hace ver no ser suficientes las precauciones dirigidas á este fin, y que sería conveniente establecer, que los trabajos de cultura de tierras, de minas, las manufacturas ú obrages, y los oficios mecánicos, se hiciesen indistintamente por la gente blanca como por los Indios, sin que en ello hubiese distincion, de cuyo modo se iria entablando este régimen, y despues de conseguido no sería tan sensible s: disminucion. Solo en los paises poseidos por los Españoles miran con desprecio los Blancos tales trabajos, pues en las Colonias de las otras naciones, $y$ en lo que se extiende la Nueva Inglaterra, es la gente blanca Européa la que se ocupa en ellos sin distincion alguna, del mismo modo que lo practican en Europa: siendo el modo de que estén bien pobladas, aprovechadas sus tierras, opulentas y ricas con las producciones que dan.

I9 No sería obra dificil conseguirlo así siempre que por el Gobierno se expidiesen y sostuviesen con empeño las providencias convenientes, acomodadas á su logro; y sin alterar en lo demas las sábias y justas leyes por donde se gobiernan, se adelantaria extinguir el crecido número de gente va- 


$$
V I G \text { ES I MO. }
$$

295

gamunda y ociosa que llena aquellos paises, haciéndola útil en alguna carrera, cuya política contribuiria no poco al fomento de las minas, pues habria mas que se dedicasen á trabajarlas en todas sus manipulaciones, y que se estableciesen formando familias, que es la máxîma que han llevado las otras raciones para poblar las suyas, y que florezcan hasta el estado opulento en que se hallan.

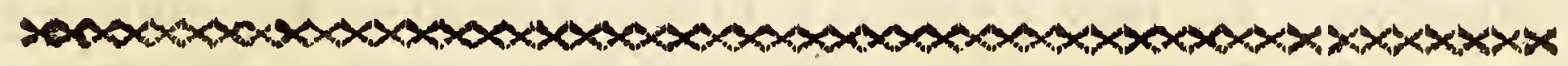

\section{ENTRETENIMIENTO XX.}

\section{Dase noticia de las antigüiedades de los Indios,} $y$ de las cosas que se conservan de ellos.

I Ilas memorias de los Indios del Perú, anteriores a su conquista, se conservan en las poblaciones, edificios y muros en las guacas ó entierros, y tambien en aquellas cosas que les eran de propio uso, como son herramientas ó instrumentillos de que se servian para hacer sus obras, y en las figuras de ídolos que al modo de dixes acostumbraban; pero los que viven en su natural libertad por aquellas partes, y en las del Norte, no dan muestras de servirse, ni de fabricar con ningun fin figuras humanas ni de animales. Estas antiguas memorias de los que fuéron sujetos al imperio de los Incas, ministran larga idea de lo que eran aquellos pueblos, y del punto de civilidad á que habian llegado: distinguiéndose entre ellos y los que no lo estaban algun género de cultura, que sin apartarlos de las propensiones propias de la raza, hacen perceptibles la distancia que hay entre el hombre abandonado á la barbarie, á la desidia y al ocio, y 
el que subordinado á las leyes de una superioridad mas instruida, adquicre conocimientos de racionalidad en las lecciones que aquella le ministra.

2 Los Indios del Perú civilizados tenian poblaciones en toda forma aun ántes de ser sojuzgados por los Incas, y les daban aquellas distribuciones que eran correspondientes al género de comodidad que acostumbraban; y así entre ellos se conocia este adelantamiento, respecto de las otras naciones de la misma raza, que aun se mantienen sin tanta formalidad, reducidos á lo mas preciso é indispensable. Esta mayor formalidad no se opone en nada á lo que se ha dicho en el Entretenimiento anterior sobre sus propiedades y propensiones, y principalmente la desidia; porque el carácter natural de una especie de gente es diverso de la mas ó ménos perfeccion que den á las cosas que son indispensables para el uso, así como en la irracionalidad de los brutos se ven unos que con mas instinto que otros, ó con mas propiedad, á nuestro modo de juzgar, disponen los nidos, hacen las cuevas y, los parages en donde se han de recoger.

3 En el Perú se conservan bastantes vestigios de los palacios de los Incas, que son de otro órden y solidez que las obras de los Indios rústicos, ó por mejor decir, que las que hiciéron las naciones ántes de ser conquistadas por ellos; reconociéndose que entre las cosas que adelantáron, sujetándolas á reglas mas metódicas, lo fué el edificar con algun género de suntuosidad; por esto pueden mirarse las habitaciones ó viviendas de los Indios en tres clases : la primera la que les enseñó la necesidad desde los tiempos mas remotos, reducido á unas cabañas ó chozas en figura circular, como las que se han explicado en los anteriores Entretenimientos, y se hallan todavía entre el comun de ellos y en las Punas, como tambien en las naciones de la parte del Norte, que no han recono- 
$V I G E S I M O$.

cído níngun género de cultura: la segunda es la que se ve en los pueblos antiguos del Perú; y la tercera la que se practicó con las disposiciones y reglas que inventáron los Incas: en todas ellas hay alguna parte que guarda semejanza, aunque varían en la figura de los edificios, en la altura y en las comparticiones interiores: los de la primera especie no necesitan mas explicacion que la que se ha dado, siendo el método general que usan las naciones, que permanecen en la primera rusticidad en todas las partes del mundo.

4 Son bien comunes los vestigios que se conservan en el Perú de las poblaciones antiguas, y los hay en todas sus Provincias, infiriéndose por ello su crecido número ántes de la conquista. Entre otros parages que lo testifican son, á lo que parece, de los que estuviéron mas poblados los Valles de las Capillas, por su propio nombre Guanquina, Guanca-Conacbi, y Topara, como ya queda en parte advertido. Así en las distancias que hay del parage que al presente llaman Capillas, hasta Topara, que es de 4 á 5 leguas; caminando hácia la sierra, se ven por uno y otro lado rastros de I5 ó 20 pueblos que allí habia; y siguiendo hácia la parte opuesta, que es la que conduce al mar en la misma conformidad, al presente no hay poblacion formal en aquellos parages, y solo tal qual casa ó rancho donde habitan Mulatos ó Mestizos, y estas están muy separadas unas de otras, siendo de cañas su construccion.

5 Las poblaciones estaban regularmente en las pendientes de los cerros que forman aquellos vaIles; y aunque en estos hay bastante exterision, no la ocupaban, eligiendo los lugares elevados que dominasen, acaso para tener esta ventaja; y en caso de ser acometidos por los que les hacian la guerra, Pp

po- 
poderlos rechazar con mas facilidad, y no estar expuestos á ser sorprehendidos. Tambien llevaban en ello la mira de que estuviesen sus pueblos ventilados y libres de los vapores que se levantan de las llanuras por donde corren los rios, que eran las tierras que aprovechaban en sus sembrados, lo qual debia hacerlas ménos sanas que las otras que estaban con alguna elevacion.

6 La capacidad de estas poblaciones era varia; pero regularmente se observa desde 300 pasos de largo en unas hasta 600 , que era la de los mayores, siguiendo segun corren los valles. Su ancho es de 80 a roo pasos con corta diferencia : este ámbito ocupaban las casas, y separado de ellas, hácia la parte alta del cerro, se conservan los vestigios de fortalezas, no en todas, pero sí en las mayores, y hay apariencias de haber sido establecidas por los Incas despues que sojuzgáron aquellas naciones, asi por la circunstancia de dominarlas, como por su construccion, que es uniforme á la que se ve en las que se fabricáron por disposicion de aquellos Soberanos, consistiendo en tres murallas, con sus terraplenes, las quales están en forma de gradería; superiores unas á otras, con aquella altura que va tomando el terreno de los cerros de abaxo para arriba. Estos muros siguen las desigualdades que tienen los cerros por la parte exterior, y baxo de cada uno se reconoce haber estado rodeados de un foso.

7 La precisa disposicion de las casas está desfigurada con las ruinas que causa el tiempo, pero se conoce bien que constaban de 3 ó 4 piezas habitables, siendo una de estas la que destinaban para abrir en su suelo el panteon ó sepulcro donde se enterraban: las puertas de su entrada son pequeñas y estrechas, teniendo de altura cosa de una vara, 
VIGESIMO.

ó poco mas, y dos tercias de ancho, como ya se dixo, siendo la única respiracion que habia en ellas; pues no acostumbran ventanas. Dentro de las piezas, en el grueso de las paredes, hacian unos nichos como alacenas, cuyo ancho era de dos tercias, su alto una, y de profundo una quarta: de ordinario hacian dos contiguas, que distaban entre sí vara y media ó dos. Este uso fué general en toda la raza de Indios; pues en las casas de los de la Luisiana y de todo el Norte lo siguen sin diferencia en los tamaños y en la disposicion de hacer dos contiguas, como para que sirviesen de adorno en la pieza, al mismo tiempo que de comodidad, para poner aquellas pocas cosas usuales que tenian.

8 La materia de las paredes es de tierra en forma de tapias; pero no las hacian al modo de las de Europa: las suyas seguian á lo largo todo el que tenian las paredes; y quando la extension de estas era demasiada, las hacian en dos, ó tres trozos. Los tapiales no tienen una misma altura, variando mucho en ello: el uno suele tener 3 pies, y el inmediato alto ó baxo dos, ó solo uno; ni tampoco tienen la misma altura en todo su largo; por el un lado es de dos pies ó algo mas de alto, y luego va disminuyendo hasta finalizar el uno en el otro; pero esta desigualdad la suple el que está inmediato por la parte de arriba ó por la de abaxo de ella. Las mas altas de estas paredes, compuestas de 4 ó 5 tapiales, no tienen mas que dos varas ó dos y media; y hallándose sin techos las casas, no puede saberse todo lo que tenian; pero juzgándolo por las puertas, y por la generalidad de no exceder en el tamaño algunas de las muchas que exîsten, se infiere ser esta su altura regular: sobre ellas se levantaba la techumbre, que seria correspondiente á la figura de las casas quadradas ó quadrilongas. El gro$\operatorname{Pp} 2$

sor 
sor de las paredes es algo ménos de media vara; siendo digno de reparo que sin otra fortaleza que esta, y sin techumbre han resistido desde su construccion todo lo que ha corrido de tiempo hasta el presente.

9 Estos edificios que allí hacian de tapiales en otras partes eran de adobes; en otras de piedras brutas ligadas con barro; en otras de madera, y en otras de cañas, correspondientes á los materiales que tenian mas á la mano y á los climas que cada nacion habitaba.

Io La misma especie de casas se halla en la parte alta del Perú, en donde tenian pueblos formales, bien que en estos no faltaban de las otras mas simples, en figura redonda, al modo que todavía las hay en los lugares despoblados; y se extiende igualmente á ellos la práctica de los sepulcros subterráneos; pero con alguna mas prolixidad que los de los valles de que se ha tratado; porque los enlucian por adentro con un género de composicion tan dura y lustrosa, que quedaban muy lisas, é impenetrables à las humedades, no ménos que á las savandijas que suelen criarse en tales lugares; infiriéndose de ello el particular cuidado que tenian en la conservacion de los cadáveres.

I I Entre los edificios grandes en que se acredita la magnificencia y poder de los Soberanos del Perú, es de los principales el del valle de Pacbacamac, nombre que entre ellos significa el Dios Supremo, invisible y desconocido, ó el Criador. Este se halla cerca del pueblo de Lurin, que dista de Lima 5 leguas. Al presente solo existen de él ruinas, con algunos trozos que están en pié : hállanse divididos en tres distintos parages, que consisten en un palacio, una fortaleza y un templo ó adoratorio, reconociéndose en todos por aquel término que les permitia la rus- 
ticidad, un ayre suntuoso y grande, que denota las ideas de los Soberanos que los hiciéron fabricar.

I2 Hácia la parte del mar, donde termina el va11 e de Pachacamac, en un parage elevado de arena están los vestigios del palacio, cuyos muros subsisten todavía hasta la altura de 4 á 5 varas, mirado por la parte exterior; pues por la de adentro no es tanta su altura. Descúbrense en él varias habitaciones ó viviendas; y á no hallarse comprehendido debaxo de una cerca, con la qual unen los murallones de las comparticiones interiores, y sin disposicion de calles, podria discurrirse que mas bien era poblacion que palacio, por tener mas de media legua de circuito; pero este ámbito no componia, á lo que denotan las señales, mas que un edificio; y no puede formarse juicio de las distribuciones que tenia, porque se halla desfigurado en montones considerables de adobes, que se han quitado de las paredes, con el fin de descubrir entierros, y aprovecharse de las riquezas que se dice habia ocultas, incitando á ello la noticia de haberse sacado algunas de consideracion.

13 Como á 600 pasos de este palacio, sobre un cerro de arena como el antecedente, y siguiendo siempre hácia el mar, está la fortaleza, que tambien es de adcbes, y consta de tres muros, mas anchos que los del palacio, dispuestos en forma de gradería, de modo que el mas interior domina al de afuera sucesivamente. Cada muro tiene su terraplen bien ancho, y la altura de ellos es muy competente, excediendo tambien la que subsiste á la del palacio: su capacidad es de un quarto de legua en circuito, ocupando la cumbre del cerro con parte de su pendiente al rededor de él: distínguense todavía las viviendas de los que se mantenian en ella, y los nichos, que al parecer eran cuerpos de guardia, del 
mismo modo que los que tenian en las fortalezas de piedra que hacian los Incas en otras partes.

I4 A una legua de la fortaleza, en la medianía de la pendiente de un cerro bien alto, al Sur del valle, está el templo nombrado Pacbacamac, cuyas paredes exteriores subsisten en toda su altura, ó poco'ménos; pero en lo interior se halla muy deshecho, con el mismo motivo que hubo en los otros de buscar entierros. Su exterior es correspondiente en lo grande á la de las otras obras, sucediendo lo mismo en quanto á la solidez. Por razon de la altura señorea los demas edificios, descubriendo con ventajas las llanuras de aquel pais.

I5 En todo esto se ofrecen varias cosas que notar, y son los adobes de que están hechas las obras, la elevacion de los parages, la magnitud que les diéron, y las dificúltades que venciéron para conseguirlas.

I6 Los adobes son de distinto tamaño que los regulares, pues tienen dos tercias de largo, media vara de ancho, y una quarta de grueso. La tierra de que se hiciéron fué preciso llevarla del valle, mediante á que en los cerros donde están los edificios no hay mas que arena muerta, y son totalmente áridos: su composicion es tierra y arena, pero sin estar cocidos son de una dureza como piedra: se conservan sin rajarse, ni haberse deshecho con el tiempo, aun los que se hallan fuera de colocacion en montones recibiendo la humedad de las garúas; lo qual da lugar á pensar que tuviéron algun particular método de trabarlos para que se endureciesen sin abrir rajas, cuyo secreto se ignora al presente, pues los que se fabrican en estos tiempos no tienen esta macicez y dureza, aun siendo menor su volumen.

I7 Es reparable que teniendo allí cerca el valle de Pachacamac, fertilizado por el rio del mismo nombre, 
VIG ESIMO.

bre, y de mucha amenidad, lo dexasen y fuesen á establecer el palacio y el adoratorio en la aridez de la arena, y en aquellos cerros donde la vista no tiene cosa que la recree. La causa de esto parece que fué el darles una situacion ventajosa para que no pudiesen ser sorprehendidos, mirando la seguridad de las personas de los Soberanos con preferencia á las comodidades y á la diversion: á esto se junta ser lo mas ventilado y ménos expuesto á enfermedades, pues en el valle, por razon de estar en baxo y de los $\$ a-$ pores húmedos del rio, no son los ayres tan puros y saludables como en las alturas, donde siempre corren los que son generales en aquellas costas.

I 8 La grandeza con que hiciéron estos edificios no pudo ser mayor, como lo dicen los dilatados recintos que ocupan el grosor extraordinario de los muros exteriores, que no tiene comparacion con ninguno de los que se conocen de la antigüedad, principalmente en los palacios de mas ostentacion, y otros del uso civil, pues aun exceden al grosor que se da modernamente á los muros de fortificacion. La igualdad con que están trabajados parece explica el designio de que hiciesen resistencia á lo mas dilatado de los tiempos, y se mantuviesen contra sus ordinarios acaecimientos; como hubiera sucedido por muchos siglos si el deseo de buscar las riquezas, que se juzgaban enterradas, no se hubiese empleado en demolerlos, anticipando su destruccion á lo que podian discurrir, los quales fabricáron, y quedando para memoria aquellas partes de muros, disformes en sus proporciones, que indican lo que serian en las comparticiones interiores.

I9 Para su fábrica, siendo de tanta magnitud, son sin número los adobes que se empleáron, y preciso conducirlos del valle, que dista algo mas de media legua, venciendo ademas de la distancia las cues- 
tas para ponerles en las alturas, agregándose al trabajo del transporte el de la precision de llevar el agua para las mezclas de las obras, y para el crecido número de gente que se empleaba en ellas, pues en sus inmediaciones no la hay, ni indicios de que practicasen pozos, cuya invencion parece no conocian, por no encontrar sé̃ales de ellos en sus poblaciones; pero aun quando no fuese así, alli no eran de uso por las circunstancias de los parages; y es de presumir que la llevaban del rio, por ser la mas inmediata. Este inconveniente subsistia despues para el crecido consumo de aguada, que debian hacer los que se aposentaban en aquellos edificios, que á proporcion de sus capacidades vendrian á componerse en vecindario capaz de formar una ciudad ó grande poblacion, por cuyo motivo se hacia preciso que se emplease un número muy quantioso de Indios solo en el exercicio de conducir el agua; luego se agrega el correspondiente á los demas menesteres, y así hacen comprehender estas circunstancias el gentío numeroso que habia en aquellos paises ántes de haberse hecho la conquista; pues en la lentitud natural de ellos, y en la circunstancia de hacer los acarreos por lo mas comun á espaldas de Indios, tenian abundantemente para perfeccionar tales obras, y superar las dificultades que parece se acrecentaban de intento á fin de hacerlas mas recomendables.

20 Descúbrense entre las mismas ruinas y en las demoliciones que se hacen osamentas de cadáveres en bastante porcion, y muchas de las calaveras, conservando todavía el cabello, pedazos de vasijas de aquellas que eran de su uso, y entre estas cosas una gran red rota y consumida por partes, que á lo que se reconoce serviria para pescar, cuyo hilo es de pita, siendo estas cosas lo único que ha quedado despues de las muchas piezas de alguna curiosidad, y 
de otras de valor que han sacado los que han tenido la ocupacion de deshacer los edificios, cuyo embeleso aun no ha cesado, exercitándose en él de tiempo en tiempo algunos que se aplican á continuar la demolicion.

2 I Por las tradiciones y noticias de aquellos tiempos eran este palacio, adoratorio y fortaleza las mas considerables obras que se encuentran de su especie por aquellas partes; y así lo da á entender la extensicn dilatada y solidez con que las dispusiéron, haciendo ostentacion del poder que tenian, y de su aplicacion á grandes empresas, aunque sin gusto, apartándose de la limitacion de luces que se notan generalmente en los Indios, cuyas ideas, por lo ordinario, están ceñidas á lo que piden las necesidades de la vida, sin trascender á suntuosidad ni magnificencia.

22 No se sabe con certeza quien fuese el autor de estas memorables obras; en lo comun se tienen por de los Incas, y hay señas que lo persuaden; pero esto tiene la contra de que al tiempo de hacer ellos la conquista de aquel valle estaba ya en él establecido el culto al Dios Pachacamac, y edificado su templo, bien que este podria haber sido ampliado y mejorado por los Incas, quienes, segun las Historias de sus reynados, no dexaban de conocerlo, y lo veneraban interiormente como una de las deidades supremas; pero por no ser visible llevaban la opinion de que no correspondia hacer, respecto de él, las demostraciones exteriores que practicaban con el sol y con la luna. El Señor que dominaba en aquel $y$ en los otros valles contiguos, llamado Cuismancu, tenia por el primero de los Dioses á $\mathrm{Pa}-$ chacamar, á quicn reconoció por autor y mantenedor de todas las cosas, y en esta atencion estaba erigido el templo en aquel valle, y deberia atribuisse

Qq 


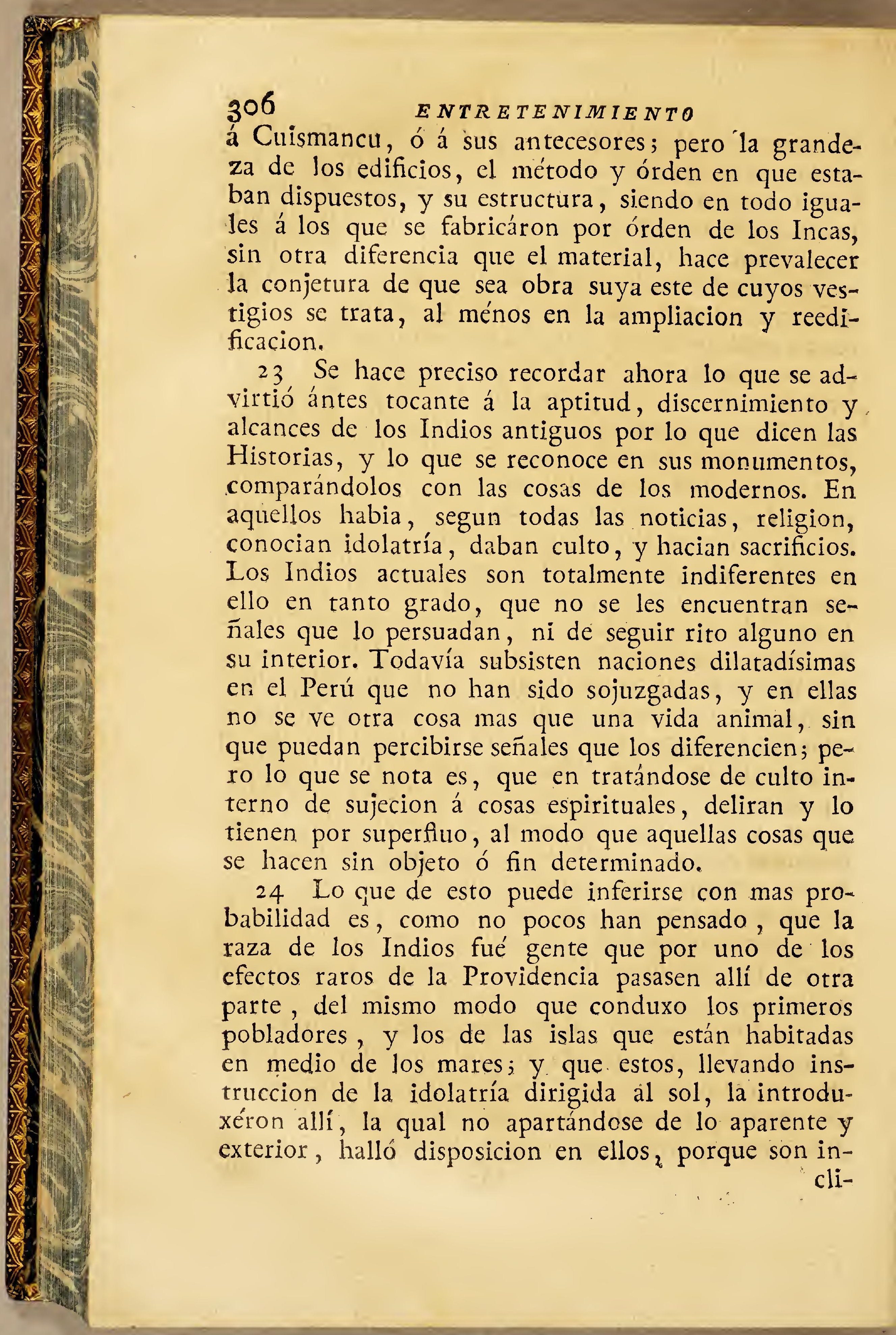


VIGESIMO.

clinados á todo género de actos de esta especie; $y$ por aquí se propagó con facilidad, tanto mas que sus fiestas han sido siempre acompañadas de la embriaguez y bayles, que es lo que mas les agrada, y que aquel culto no les sujetaba á ocupar las ideas en los actos internos del alma, que miran con indiferencia. Estos mismos les darian el modo de hacer grandes edificios; y abundando mucho el gentío lo dedicaban á fabricar los que se ven, practicándolo con la que habia de sobra, cuya máxîma siguiéron los Incas para evitar que con la ociosidad cavilasen alborotos, y se sublevasen.

25 En esta forma los edificios de Pachacämac, con otros diversos que se encuentran, no obstante 1o. que dicen los Historiadores, debe creerse que concurriéron á su fábrica los Incas en algun modo, y por esto fuéron tan semejantes á los del Cuzco, á los del reyno de Quito, y de otras partes donde se extendió el dominio, pues no les falta circunstancia; y así las comparticiones, en lo que puede alcanzarse á reconocer, los cuerpos de guardia, el órden de colocar los adobes, y los restantes requisitos, son lo mismo que los que se reconocen en aquellos otros. Ademas de esto, el Señor de Pachacamac y de Rimac no podia ocupar un palacio tan disforme, y solo para los Incas, con toda su comitiva, venia bien; porque no se tiene noticia que otros Soberanos, de los que habia en aquellas partes, tuviesen familia, y séquito tan crecido, que necesitasen edificio de tanta magnitud para hospedarse.

26 Otro palacio algo semejante al antecedente hay en Herbay, que es la orilla meridional del rio de Cañete, distando de Pachacamac $23 \frac{x}{2}$ leguas: es de bastante magnitud, aunque no tanta como aquel, teniendo de largo 400 pasos, y el correspondiente

Qq 2 an- 
ancho: su situacion es sobre el barranco que forma el rio, y está construido de árboles de igual tamaño á los otros: las parades se mantienen en pié con la regular altura que tenian; pero en lo interior se halla demolido con igual motivo al que se dixo del otro.

27. Tambien se conservan a retazos las paredes que acompañaban los caminos en el que conducia del Cuzco á Lima. De estas se encuentran en distintos tránsitos de aquella larga distancia, manteniéndose en pié, sin que hayan hecho mella en ellas los incidentes del tiempo, pues en los tramos que se han arruinado ha sido por la diligencia de deshacerlas para aprovechar sus adobes en las fábricas modernas.

28 En la raza de los Indios es necesario distinEuir los actos y operaciones del entendimiento de Ios que son de pura manipulacion ó industria: ó por otro modo aquellos en que trabaja el discurso de los que solo se terminan á los sentidos: en los primeros son totalmente negados, torpísimos, y sin discernimiento ni comprebension; dimanando de ello no hacerles impresion aquellas cosas que se les dicen para que conozcan la razon, y la distingan de 1o que se opone á ella: no alcanzan á sentir lo que puede resultar de las malas oferaciones, y por esto obran sin reflexion, ni pensar mas que en lo presente. Lo propio sucede en los asuntos de religion, oyen con serenidad quanto se les dice; pero ni se. les imprime, ni causa en sus ánimos noyedad, de suerte que con la misma disposicion reciben lo que se les anuncia de la verdadera, que de qualquiera otra, porque ninguna mueve la voluntad, ni les sujeta á seguirla por razon de convencimiento, y de formar idea, que de ello deben esperar una vida eterna. Si se quiere que concedan en alguna cosa, lo hacen sin di- 
VIGESIMO.

dificultad; y si aquello mismo se les persuade á que lo nieguen, convienen sin repugnancia. Por exemplo, se les dice que el diablo es malo: responden que no les ba beclo mal alguno, pero asi será. Se les cice del mismo modo de uno de los Santos que es lueno; y responden igualmente que asi será. Si esto se les vuelve al contrario, conviene en la misma forma; sacándose de ello que ni uno ni otro hace efecto en sus ánimos.

29 De las cosas de este mundo ni desean ni esperan mas de aquello preciso para el dia, y en estas el satisfacer la pasion de la embriagucz: de las del otro las ideas que puedan tener son muy débiles, y segun ellas no necesitan hacer méritos para ir allá, forque no dan luz del modo en que la conciben, figurándose que en este mundo, como en aquel, todo es igual en la clase de hombres, y que el fin es uno mismo; con que por estas señales no puede penetrarse qual sea el fin que llevan en la idolatría estos que son civilizados, y la conservan, segun el sentir vulgar, desde los tiempos de la Gentilidad: no se les ve sacrificar ni hacer ofrendas, ni otros actos que lo acrediten, ignorándose en qué consiste la que se les atribuye.

$3^{\circ}$ Las cosas aparentes y actos exteriores ocupan todo su cuidado, y scn en algunas obras industriosos; pero esto no es particular, ni arguye las mayores luces del entendimiento pues de los animales se ve que disponen las obras para la conveniencia con tanta delicadeza, que trabaja el discurso de los hombres en imitarlas, y nunca lo consiguen con la perfeccion que ellos las hacen. Las redes de la araña indican la mayor industria y artificios; lo mismo sucede con los capullos de los gusanos, las casas de los castores dispuestas dentro del agua, y sin que les entre, ni moge esta su delin 
licado y suave pelo; la variedad de nidos "de "los páxaros, que no tiene fin, ni pueden imitarse, y otras muchas cosas que les enseña el instinto, y dicta la necesidad: por esto en las de los Indios puramente exteriores, aunque parezcan grandes no contienen cosa de discursivo por donde se perciba haber trabajado mucho el entendimiento, diferenciándose en lo mas ó ménos grande, pero sin variarse, ni encontrarse adelantamiento de unas á otras; y así vista una, lo están todas. Los de la parte del Norte hacen pinturas en algunos cueros, que preparan al modo de gamuzas, pero en ello imitan aquellas figuras que tienen mas presentes; y empleando una lentitud y paciencia sin igual, necesitan que la vista vaya corrigiendo lo que yerra el tino, $y$ que les dé reglas que suplan por la falta de idea en lo que desean sacar, convenciéndose en ello ser en todo materiales. 


\section{ENTRETENIMIENTO XXI.}

Explícanse algunas obras de los Indios para sus precisos menesteres, $y$ algunas figuras á manera de ídolos, ó dixecillos.

I La necesidad ha sido la primer maestra de las gentes para las cosas del preciso uso, y con la aplicacion han pasado á las que son de gusto, ó de conveniencia, resultando que las mas inclinadas al trabajo han adelantado mas que las otras. En los Indios se reconoce poca variedad en punto de obras; pero no obstante se advierte haber hecho algunas para la comodidad, ó para el adorno, distinguiéndose en esto las naciones entre sí, segun el grado de cultura ó de civilidad que llegáron á tener. En una cosa han sido iguales, y sin discrepancia industriosos, que es en las armas, pues generalmente todos usaban del arco y flechas, y los hacian sin diferencia sensible de un mismo modo, imitando en ello á las naciones de la antigüedad que poblaban el Asia, y las otras dos partes del mundo; de modo que siendo comunes en cllo, se deduce haberse derivado de un mismo principio, y que fuéron las primeras armas de que usáron, aunque despues fuéron introduciéndose otras. Entre los Indios civilizados del Perú no se conserva ya memoria de cllas; y aunque del todo no está perdida en las naciones del Norte, es muy raro el manejo que hacen de ellas, habiéndose acostumbrado á la escopeta, cuyo uso les han introducido las naciones Europeas Francesa é Inglesa, como queda dicho: enseñan pues el del arco y flecha á los muchachos, y son diestrísimos 
en él; pero despues quando llegan á grandes 10 dexan para aplicarse á las otras. Las naciones que viven retiradas de los Europeos en el Norte, sin tener trato con ellos, y las que permanecen en su libertad en lo dilatado de las dos Américas, no conocen otras, sirviéndose agilmente de ellas para la caza, para pescar, y para las guerras. Los arcos los hacen de madera recia flexible; la cuerda es de nervio de animal; y las flechas de otra madera recia $y_{i}$ pesada, cuyas puntas, ó las endurecen con el fuego, ó engastan en ellas pedazos de pedernal para herir. Tambien usan lanzas de poco mas de dos varas de largo, no gruesas, de madera igual á la de las flechas, las quales arrojan con la mano diestramente, y con ligereza. Los civilizados del Perú no conocen al presente mas armas que las piedras, y, estas las despiden asimismo con la mano, sin la ayuda de hondas, dirigiéndolas con particular acierto. Esta nacion es muy diversa al presente de lo que fué ántes, en quanto á la agilidad con que hacia aquellas cosas de que se servian quando se mantenian baxo del dominio de sus Soberanos naturales.

2 Entre las piezas que se encuentran en las antigüedades, son las hachas de cobre; estas por el un lado tienen el cortante, por el otro una punta agu$\mathrm{da}$; en el medio tienen el ojo por donde se encababan: este cabo no era mas largo que lo necesario para el manejo con la una mano; por lo que se ve les servian á un tiempo de señal ó insignia distintiva de la soberanía, y de armas ofensivas que usaban los Reyes. Lo primero era al modo que los cetros, donde se indica la suprema dignidad y el poder; y lo segundo como insignia propia de la justicia. Es regular, segun el número que se suele haIlar, que ademas de los Soberanos las usasen los orros xefes, en quienes sobstituian parte del poder, para 
VIIGESIMOPRIMO.

que gobernasen los pueblos. Los que estaban empleados en el mando para las conquistas y guerras, y los Príncipes de la sangre Real las tenian con alguna distincion correspondiente á la autoridad y exercicio de cada uno.

3 Igualmente se encuentran otras piezas en figura de estrellas, cuyo diámetro, tomado de las extremidades de las puntas, es de 5 á 6 pulgadas, y en estas las hay de dos materias, y de quatro diferentes hechuras: la primera es de cobre, con el diá metro que se ha dicho; en la medianía tiene un agujero de pulgada y media de diámetro para que entrase el cabo: su circunferencia está dividida con igualdad en seis partes; cinco de estas son las que forman la estrella; y la sexta es el cortante de hacha: las puntas son redondas, rematando agudas.

4 La segunda especie es en tamaño y figura como la primera; pero se distingue en que no tiene cortante de hacha, constando de 6 puntas iguales, en forma de estrella, y son redondas.

5 La tercera se diferencia de la antecedente en que las seis puntas que hace la estrella no son redondas, sino en figura de hojas, con filo por los dos lados y por la punta, siendo su ancho el que tiene la estrella, que por la encabadura es de una pulgada, ó poco mas, y va disminuyendo hácia las puntas que no rematan agudas, sino algo circulares.

6 Ia quarta es como la segunda, á diferencia de ser piedra, y esta es de una calidad dura y de eolor obscuro; siendo digno de reparo, que no teniendo herramientas de acero ni de hierro, porque no conocian estos metales, pudiesen darles la perfeccion que tienen, y hacerles el agujero en el medio en figura circular perfecta, lo qual no podia sonseguirse de otro modo que con mucha pacienR. cias 
cia, á fuerza de frotar unas con otras.

7 La primera de estas quatro especies cra, segun lo demuestran las señales, la que servia de insignia á los Soberanos; y las otras á los que gobernaban, usándolas tambien como armas para la guerra, al modo que era comun en la antigüedad con las mazas, pues su figura y tamaño indican no ser para otra cosa que para descárgar sobre los enemigos ofendiéndoles. Este uso se ve que á semejanza del de las flechas lo lleváron desde los principios, habiéndolo adquirido en donde lo tuviéron las demas gentes que guarnecian con puntas las mazas de las armas.

8 Los Indios de la parte del Norte usan unas hachas de mano, semejantes á las de cobre que se han explicado, con punta y corte: los Franceses las llaman casatete; y asi esta nacion, como la Inglesa, son las que les proveen de ellas, diferenciándose en ser de hierro y acero; pero es regular que la figura fuese tomada de las que viéron en sus principios, acreditándolo así la circunstancia de no ser arma que se acostumbra en Europa, pues aunque las practican en. los navios, no dexan de tener alguna diferencia; y de ello se colige, que fué comun este uso entre los de la parte meridional y los de la mas septentrional; de suerte que en las mas de las cosas se reconoce uniformidad, sin que las dilatadas distancias $y$ el curso largo de los tiempos, que han pasado desde que se dividiéron del orígen, las hayan variado aun en los accidentes ménos esenciales.

9 Hállanse tambien hojas de metal de 5 á 6 pulgadas de largo, y poco mas de una de ancho, siendo su grueso dos líneas: por la una extremidad hace filo algo circular, y por la otra es la cabeza al modo de los escoplos de hierro, indicándose ser herramienta para corte al modo de las que usan los car- 
VIGESIMOPRIMO.

pinteros. Otra especie de hacha se encuentra de la misma materia que las antecedentes: su grandor y figura circular es como las cuchillas que usan los turroneros; con la diferencia, que la empuñadura para hacer fuerza es del mismo metal que la hoja.

ro Conocian aquellos Indios las mezclas de los metales en alguna parte, y se manifiesta en los colores de las piezas que se han explicado: unas son coloradas, tirando al del cobre natural; otras amarillas como el laton, y entre estos dos hay variedad; unas piezas son mas parecidas al laton que otras; pero en todas ellas se repara que sin estar cubiertas de berun alguno, no crian verdin ó cardenillo; sacándose de ello, que la mezcla que les ponian era tal, que mudaba enteramente la qualidad. del cobre, ignorándose este secreto; pero lo mas raro es, que habiendo conservado los Indios, por el largo espacio de muchos siglos, sus usos y costumbres, y el modo de hacer aquellas cosas que entre ellos eran comunes, en el corto que ha pasado desde la conquista han olvidado enteramente la memoria de las cosas ingeniosas, sin sucederles lo mismo con las primeras; y asi es un asunto para eilos desconocido en el tiempo presente la fundicion y mix tura de los metales, el modo de vaciarlos, la fábrica de las vasijas antiguas, de que se dará razon mas adelante, el modo de labrar la piedra dura, con aquellas herramientas de metales dóciles, y el de fabricar las armas de que se servian entónces; siendo tal este olvido, que los civilizados no acertarian á preparar una flecha, engastándola el pedernal, ni á colocarla las plumas, para que fuese derecha á donde la encaminase el impulso, mucho ménos á disponer el arco en la debida proporcion: esto mismo, que para los que subsisten en la barbarie primitiva es un juguete, para los sucesoRr 2

res, 
res de los que fuéron en un tiempo mas ágiles, es un imposible, sin que haya mas razon para ello que la filta de uso.

I No solo en las estrellas $y$ en las hachas se distinguian, sino que unas eran de color que tira a roxo, y otras amarillas : sucedia lo mismo en las herramientas para trabajar, lo qual da idea de que hacian las merclas para darle dureza al cobre, y tambien para variar el color, y que fuesen mas particulares á la vista.

I2 Usaban de pinzas, que hacian del mismo metal que las otras piezas : no hay duda que las diferenciarian en los tamaños; pero las regulares son pequeñas, de pulgada y media de largo, y media de ancho; delgadas, consistiendo en una hoja de meial, doblada por la mitad de su largo, con filo en las bocas, y alguna elasticidad. Estas les servian para arrancar los bellos de la cara, quando con la vejez empezaba á salirles, porque siendo por naturaleza lampiños, se miraria como cosa impropia dexarlo crecer quando la edad lo producia; al modo que for el contrario en las naciones Orientales, $y$ entre los Mahometanos es irregular cortar la barba, ó en los Europeos en estos tiempos mantenerla crecida, á excepcion de algunas naciones del Norte, que las conservan como en lo antiguo; pero los Indios civilizados en el tiempo presente no lo practican.

I3 No se encuentra entre los vestigios de aquellas antigüedades instrumento que sirviese para golpear, como martillo ó maza, y es que estos los harian de piedra, y se hallarán desfigurados; pero siempre es reparable que en las huacas ó entierros no los haya. A! modo que fundian los metales para los fincs que se han explicado, hacian con ellos ciertas figurilias; unas cran macizas, y otras vacia- 


\section{VIGESIMOPRIMO.}

das, sumamente delgadas y pequeñas, como para traerlas colgadas; y no solo las disponian de metal, sino de plata, de oro, de piedra y de barro cocido. Su representacion era de los Indios que llaman Cpas, que son monstruosos é insensatos, no reconociéndose que hicieran de otras ménos disformes. Esta especie de defectuosos abunda mucho entre ellos en uno y otro sexô, y parece que á la circunstancia de la disformidad, es consequiente la demencia, porque no se reconoce lo uno sin lo otro. Sus figuras son horrorosas en cara, cabeza y cuello, teniendo este poblado de eminencias, ó papcras quasi tan abultadas como la cabeza. Los Indios los atribuyen varias particularidades, y principalmente la de ser adivinos, consultándoles en sus urgencias: los miran con veneracion, y como que tienen algo mas de particular que los orros hombres, por cuya razon forma ban sus figuras en modelos á modo de dixes, que es lo que se tiene por ídolos, bien que no se sabe que les diesen algun culto ó adoracion, ni que en la antigüedad los reputasen por cosa divina. En los que viven á su libertad no se reconoce tampoco semejante idolatría, porque si tal fuese procurarian conservarlos y mantenerlos con alguna veneracion; de lo que puede concluirse, que los que estuviéron civilizados contraxéron este uso de las leyes que les impusiéron los Incas, ó los primeros hombres que pasáron de otras partes á sojuzgarlos.

14. Las ofrendas que dirigian al sol en sus templos tenian por objeto el agradecimiento á los beneficios que les hacia por medio del calor que comunicaba á la tierra, y á la luz con que alumbraba, porque dexándose llevar de lo aparente, aunque conocian al Dios invisible Pachacamac, se contentaban con venerarlo interiomente, y atribuian al astro brillante, por los efectos aparentes, to ghe 
correspondia al Criador que lo gobierna; pero no se encuentran entre las figuras que hacian alguna que lo representase, ni otras que no sean las que se han dicho, no siendo facil comprehender qué fin llevaban en ello.

I5 Reconócese en estas gentes particular inclinacion. y complacencia á las figuras feas con estravagancia; siendo de esta especie las mascarillas que hacen de madera para desfigurarse; y sin tener estas cosa de monstruoso, son tan feas, que no les imitan las de Europa, sin embargo de las varias ideas extraordinarias que hay para ello: "quando llega el ca. so de disfrazarse toman los modos mas extraños y ridículos que se puedan inventar: á este respecto no es extraño que en los dixes ó idolillos copiasen á los Opas, que son los mas feos y horrorosos de quantos la idea pueda figurarse en la especie humana. Algunos quieren que estas figuras las tomasen de aquellas en que se les aparecia el Diablo para inducirlos á que se mantuviesen en sus errores, vicios. y supersticion; pero de esta opinion es forzoso prescindir por las dudas que pueden ocurrir sobre el modo y circunstancias de estas apariciones: 10 mas regular es atribuir á la grande ignorancia el aprecio. y distincion que tributan á estas figuras y á las personas de notable deformidad; y aun al presente en los casos de cosas perdidas, ó en los ganados extraviados, acuden á ellos para que les den noticias de sus paraderos, confirmándose su inadvertencia en la flaqueza de suponer con mas dotes naturales á los de. mentes que á los que tienen cabales los sentidos. Por estas cosas queda el discernimiento y la razon en ellos en el estado de la infancia, aunque lleguen á la mayor edad, pues al símil de los muchachos se entretienen con aquellas figurillas, sin que el aprecio pase mas allá de lo que es diversion, y depositan en la es- 
tupidez las esperanzas de sus Geseos. Cierto Sabio del primer órden en Europa, tratando de los Indios, decia que era de las cosas mas particulares en el mundo que hubiese una nacion dilatadísima, que subsistian siempre en el estado de niños, aunque tuviesen ochenta años, atento que sus operaciones eran en qualquier edad que se hallasen como si no hubiesen salido de los 7 ó 9 años.

I6 Sácanse tambien de los entierros unas vasijas de barro cocido, que tienen mucha semejanza con las que se suelen ver de la antigüedad Romana, Griega ó Egipcia, cuyas figuras se encuentran representadas en los geroglificos y en los dibuxos Mosaycos de aquellos tiempos. El tamaño de estas es de vara y quarta, ó algo mas: el cuerpo de la vasija es mas largo que grueso, rematando en punta por la parte de abaxo : el cuello largo y seguido, y la boca ancha, haciendo como embudo: en otros no es la boca tan esparcida, pero guarda la misma figura, $y_{i}$ el barro se reconoce estar bien cocido. Estas piezas, de las quales no dexa de haber bastantes, indican que la norma de hacerlas fué llevada por los primeros pobladores, habiéndola tomado del mismo orígen de donde la tuviéron aquellos pueblos.

17. Al presente no hacen los Indios modernos las que tienen para el uso en esta moda, y así se distinguen facilmente unas de otras. Tambien hacian otras pequeñas, y algunas representando la figura de la llacma, estando echada, que por el medio del vientre tiene hueco, no pudiendo reputarse por cosa de idolos, sino que les daban aquella figura para variar la pieza, al modo que se hace entre las demas gentes. Otras hacian algo semejantes á las jarras Catalanas de beber, observándose tambien, que variaban en la calidad de los barros, pues se ven algunas negras, aunque en las vasijas grandes lo co- 


\section{0 \\ mun es ser blancas.}

I 8 Los Indios modernos conservan sín duda el uso de las balanzas desde la antigüedad; las que manejan son sin fiel, consistiendo en dos asientos de calabazos chatos, suspendidos por unos hilos de un palo, con otro hilo en el medio para levantarla; las pesas son unas piedras proporcionadas á su modo, que no guardan igualdad con el marco de España. Estas les sirven para vender la coca, el algodon y la lana, que son entre ellos los géneros que necesítan peso, entendiéndose en todo lo demas á ojo: en las piezas de antigüiedad se encuentran balanzas pequeñas, cuyos platos son de plata, y lo mismo la barretilla por donde se suspende: aquellos no son llanos, sino rematando en punta al modo de conos al reves. Estas por el tamaño parece que les servian para pesar cosa de oro ó plata, porque para las de otro volúmen no son suficientes: no se encuentra igual adelantamiento entre los Indios no reducidos, los quales parece no necesitar de ello, porque en sus cambalaches se entienden al tantéo. Los de la parte del Norte en el Canadá y Luisiana, en el comercio que hacen con las pieles de los animales que matan de todas especies, tienen un género de tarifa dispuesto por los Europeos Ingleses y Franceses, y con atencion á ella está establecido lo que se les ha de retornar de las especies que son usuales entre ellos por cada piel, proporcionado á la clase de las que venden. Orro tanto sucede con los del Sur del reyno de Chile, y con aquellas naciones de la parte del Paraguay confinantes con los reducidos: concluyéndose por ello, que el uso del peso sería introduccion que hiciéron los Incas en aquellas naciones que conquistácon. No se encuentran medidas, pero es regular que las tuviesen, las quales, considerando el modo de las de estos tiempos, serian al- 


\section{VIGESIMOPRIMO.}

gunas de aquellas vasijas de barro que fabricaban, pues las que ahora acostumbran para cosas líquidas y granos son unas hollitas de barro de la misma espe. cie que las que tienen para hacer sus comidas.

I9 Esta generalidad de cosas que se ven entre los Indios, iguales á las que fućron comunes á las gentes de las demas partes, persuade á que los que pasáron á ser pobladores de aquellas tierras no eran en corto número; porque para mantener las especies de muchos asuntos se necesitaba que hubiese pueblo formal de gentes que las observasen. Los antiguos Persas, Griegos y las demas naciones Orientales, yendo á la gucria, tomaban figuras particulares para animar el valor y aterrorizar al enemigo: se vestian ó se pintaban de serpientes, de leones, de tigres, y de otros animales feroces, y se cubrian los rostros con máscaras, que los desfiguraban. Esto mismo han practicado los Indios, y conservan todavía las naciones que subsisten en su libertad. El uso de las plumas de los páxaros para engalanarse, puestas en forma de penachos ó garzotas en las cabezas, en los brazos y en las piernas en forma de brazaletes, el de los carcaxes de flechas y de arcos engalanados para despedirlos, el de las lanzas para tirarse á la mano, y todo lo demas que se ha referido, no dexa duda en que saliéron de un mismo origen las primeras razas. El cubrirse por las espaldas con pieles de animales es otra costumbre comun, engalanándolas con pinturas; y así miradas con cuidado las cosas de los Indios y las de los pueblos antiguos, se hallan muy conformes, tanto, quanto son diversas y disonantes de los modernos.

20 En la línea de texidos se encuentran todavía en los entierros las mantas que hacian para cubrirse: estas eran de algodon; lo mas comun eran blancas; otras hacian con listas roxas y azules, cuyos tintes daban con el achote, con diversas yerbas, y con una 
especie de papas silvestres, llamada chaucha, que se crian en la parte alta, y dan el color azul: aun todavía usan de ellas las Indias. Hacíanlas tambien negras, y estas eran las que servian á las mugeres para llicllas, que es una especie de manta quasi quadrada, con que se cubren las espaldas, poniéndola sobre los hombros, y prendida en el pecho con un punzon, que llaman ticpe: de estos se encuentran en los entierros algunos, y son de plata, pero las Indias del comun suelen hacerlo de madera ó de espinas, de las quales se crian en los campos bien largas. Por lo que se ve al presente, los Indios usaban el color blanco en las vestimentas, y las Indias el negro, diferenciándose aquellos de los del reyno de Quito, que acostumbraban este mismo.

2 I A excepcion de estas piezas de que se ha dado noticia, no se encuentran otras en los entierros, y de ellas se conservan pocas; ocasionado de que las de oro ú de plata las funden, y lo mismo sucede con las de cobre ó metal compuesto, sirviéndose de ellas los plateros para hacer las mezclas. Ademas de esto, en los tiempos presentes es con ménos abundancia lo que se saca de los entierros que en los pasados, habiendo sido exercicio muy comun desde la conquista hacer excavaciones en los parages donde se sospechaba que pudiese haber depósitos, para aprovechar la plata y. oro que en varias figuras encerraban, fundiéndolos inmediatamente, sin reparo á las ideas que podian ministrar de la antigüedad. Este mismo incentivo es el que ha ocasionado la ruina de los edificios, que segun la solidez con que estaban trabajados hubieran durado algunos siglos, sin mas que dexarlos al curso $y$ accidentes regulares de los tiempos. 


\section{ENTRETENIMIENTO XXII.}

Sobre el idioma de los Indios, y juicio del modo en que es regular que se poblassen

las Indias.

I $\mathbb{E}_{\text {s opinion muy valida entre las personas eru- }}$ ditas, que poseen con perfeccion la lengua Quichuá, traer esta algun orígen de la Hebréa, con la qual le hallan mucha semejanza, por aquellas palabras que en la Sagrada Escritura se conservan de esta ; y siendo en la pronunciacion y en el sonido iguales, no dexan de ser bastantes las que se notan con esta íntima semejanza: de suerte, que juzgándolo por este principio no admite duda guardar entre sí mucha consonancia. Resta saber si el significado que tienen en la $\mathrm{He}-$ bréa es con precision el mismo que en la otra, porque las palabras de la Sagrada Escritura, que se hallan en la Quichuá, son por lo comun aquellas en que los Intérpretes no se han hallado conformes, ó que no les han podido encontrar la inteligencia que les corresponde, no siendo extraño que en lo uno se parezcan, sin suceder lo mismo en el significado: para poder determinar sobre ello con propiedad, sería preciso que los sujetos instruidos en la Quichuá, desde la infancia que la hablan y entienden en toda su fuerza, por serles natural como á los mismos Indios, poseyesen el Hebréo antiguo con la misma perfeccion, y entónces podrian hacer la comparacion de una con otra ; y por la semejanza de algunas frases, de las expresiones, y de los nombres de las cosas, vendrian en conocimiento de la igualdad que conservan entre sí, y tal vez no sería dificil darle la interpretacion que Ss 2 se 
se requiere á las que se mantienen én obscuridad en el Hcbréo.

2 En la Quichuá hay una frase, entre otras varias, que se ncta ser de las primeras que pronuncian los párvulos quando quiercn empezar á hablar, sucediendo esto con los de todas las naciones, y fuera de los Indios no es usual en el lenguage : esta es apa, que es la primera del verbo Apani, Apanqui, traer, cuyo imperativo es Apamui; y si se repara bien quando los niños la pronuncian, es señalando alguna cosa, que quieren que les acerquen, ó que les den : comunmente no se les hace caso, ni se les percibe, porque no se pone cuidado en ella á causa de ignorarse su alusion; pero entre los Indios, que se conoce por ser propia de ella, cuidan de darles lo que señalan: Apacbiy es el imperativo de remirir ó enviar; y Apariy el de tomar ó llevar; y asi para pedir, para enviar, y para llevar empiczan los verbos con las dos sílabas Apas: la palabra mama, que en todos los idiomas es asimismo de las primeras, es la que propiamente significa madre entre ellos; y así aunque entre las otras naciones empiezan las criaturas á prorrumpir este nombre en lenguage natural, despues lo varian, conservándolo en su ser y fuerza solo los Indios. A este respecto se nota, que otras varias palabras, pronunciadas en los principios ántes que tenga lugar la enser̃anza, son las primeras por donde empiczan los nombres ó expresiones del idioma, sin que muden el sonido para el lenguage usual; resultando de csto, que de no ser el de los Indios el que mas se acerque al natural, es el mas semejante á la primer pronunciacion de los niños.

3 Es cortísima esta lengua en quanto á las voces, y al mismo tiempo muy abundante de expresicnes, nacido de que una palabra mudando el acento significa varias cosas. Muchas de sus expresiones consisten solo en la repeticion de la precedente sílaba, y al fin 
un acento ổ una letra mas es lo que determina lo que se intenta explicar. Por exemplo, Acacau significa me quema, hablando del sol ó del fuego, ó de lo que se come ó bebe: Alalaus, tengo frio: Aranaú, me duele; y así estas tres frases explican las tres principales sensaciones de calor, frio y dolor; pero mudándoles la final, mudan del todo el significado, como Alawni buay, ten lástima de mí, ó compadéceme: Anallau, qué cosa tan buena, ó tan dulce : á cuya semejanza sucede con muchas otras. Hillase reducida á reglas de Gramática, con Diccionario correspondiente; y se ha escrito sobre su orígen y elegancia con la extension que pide la materia, como tratada de intento.

4 Es asimismo suave y tierna, dudándose que haya otra que la iguale en frases propias de agasajo y de cariño: no hay en ella composiciones de períodos largos, ni frases pomposas: en lo reducido de las que tiene es elegante, comprehensiva y agradable, sin tomar cosas de las otras lenguas usuales, como que nunca estuviéron en proporcion de hacerlo; por estas circunstancias se hace juicio de ser una de las primitivas, participando de algunas palabras de la Hebréa, segun se ha dicho: de lo que se puede inferir haberlas tomado muy en su orígen, y que el pueblo de donde saliéron aquellos primeros pobladores, si en el todo no eran Hebréos, era alguna otra nacion de las que vivian contiguas á ellos; con cuyo motivo, conservando su lengua natural, tomáron parte de los que estaban en mas inmediacion. Para prueba de ello hay algunas otras señales en las propensiones y costumbres que se observan en los Indios, que se acercan á las de los Hebréos : tales son la que tienen á la mentira y al engaro, no pu iendo formarse juicio de lo que dicen en muchas cosas, por ir envuelto en este vicio, y con la misma faciliuad que afirman, niegan 
la propia cosa. El engaño es tan ordinario en ellos, que se necesita de mucha sutileza para no caer en él, hallando pronta salida para la disculpa quancio se les reconviene: son zalameros, se hacen inocentes y con extremo ceremoniáticos; propiedades todas que se encuentran en los Hebréos, y en unos y en otros son naturales por herencia, sin que parezca que en ello hay estudio. De estos antecedentes se debe concluir lo que se ha dicho sobre la antigüedad de la lengua, pues en los principios quando no habia estudio de ciencias, ni uso de otras facultades y oficios, debian ser las que se practicaban al modo de la de los Indios, reducida, expresiva y elegante, supliéndose con la diversidad de los acentos que les daban á unas mismas sílabas lo que faltaba de palabras en las distintas combinaciones de ellas; y así aunque es breve y sucinta en un modo, es abundante, expresiva, suave y tierna en el otro; nacido de que con los acentos acompañan los afectos que se intentan explicar. La lengua Quichuá es la general en el Perú ; pero despues las distintas naciones de Indios tienen otras particulares, en lo qual hay mucha variedad, sucediendo entre ellos lo que en las demas partes de la tierra; pero es rara la que no tiene algunas palabras semejantes á ella, ó totalmente conformes; lo mas regular es que varíen en la pronunciacion tomando diverso sonido. Las de los Indios de la parte del Norte, con ser totalmente distintas de aquella, y pronunciadas con otra fuerza y acento gutural, tienen muchas palabras de la Quichuá, siendo bien reparable que habiendo entre unos y otros distancias tan largas, aun conservan estas señales de ser todos de una misma raza, descendientes de los primeros pobladores que pasáron á la América; lo qual corrobora lo que se ha dicho sobre los usos y costumbres, y que en el orígen mantuviéron las cosas en el estado que las lleváron, sien- 
do de esta clase la lengua.

5 Semejantes á las particularidades que se han dicho de la Quichuí son las que se conocen en la $\mathrm{He}$ bréa, siendo amplísima en expresiones al paso que es elegante, suave y sucinta; cuya semejanza, si no confirma el dictómen de proceder de ella, dexa indicios de serle muy parecida, recomendándola como la que tiene mas analogía con la que se reputa por la primitiva.

6 La Quichuá es comun en toda la parte alta, siendo la primera que hablan entre sus habitadores, y en la que se hallan versados. La Española es tambien regular; pero no dexa de tener sus imperfecciones, particularmente en el acento, cuyo vicio contrae del que es natural en la otra. Entre las mugeres es mas fácil explicarse en la Quichuá, sucediendo esto con las de todas clases, á lo qual contribuye servirse de gente India de ambos sexôs y Mestizos, así como en la parte baxa se hace con la Negra, y de estas castas. No es la misma la Quichuá en toda la extension de la parte alta; en el rey no de Quito, y por aquel lado, es diferente de la que está en uso en el Perú, variando bastante en los nombres de las cosas y en la significacion; pero la verdadera Quichuá es la del Perú, y por lo tal la general, con la qual se entienden las otras, á lo ménos en las cosas usuales y mas precisas, porque las frases y verbos principales son quasi los mismos, á diferencia del modo de la pronunciacion.

7 Ha sido siempre muy grave la dificultad de determinar el modo como pasaron los primeros pobladores á las Indias despues del Diluvio universal, trabajando mucho el discurso en buscar continuacion de tierras por las partes frigidísimas del Norte, para que hiciesen tránsito por ellas ó por las Orientales del Asia, que son las que se conocen mas próximas 
á las Occidentales y Septentrionales de la América: por otro método se ha pretendido imaginar un paso en la continuacion de tierras desde el Cabo de Bojador en el Africa é Islas Canarias, hasta las de Barlovento, atravesando el Occéano en 800 leguas de distancia, y que estas dilatadísimas tierras hayan ido desapareciendo despues, y reduciéndose á mar todo el espacio que divide por esta parte las Américas del Africa, de modo que se pretende que los Indios fuesen Européos ántes de haber pasado á aquellas partes; por otro juicio que fuesen Asiáticos, y por otro Africanos : de alguna de estas partes es preciso que saliesen; pero en el modo se ofrecen dificultades giandísimas, que parecen insuperabies al entendimiento, quando no se supone que hubiese navegacion mas ó ménos larga en el tránsito; y siendo principio constante que pasáron, es conseqüente que quando sucedió no subsistian las dificultades que ahora se figura la imaginacion.

8 Tenemos por principio sentado que las especies de vivientes de la tierra que se reservaban para la nueva poblacion, se salváron del Diluvio, por disposicion de Dios, en el Arca: que esta andubo flotante sobre las aguas, hasta que disminuidas, $y$ descubierta la tierra descansó sobre ella. Sábese tambien, quic despues de estar la tierra bastante poblada, el desvanecimiento de los hombres intentó fabricar la Torre de Babél, con el fin de conservarse si volvia á verse la tierra cubierta de las aguas. Antes de llegar á esta resolucion, y teniendo presente el Arca en que Noé con su familia se habian salvado, era regular quic fabricasen otras semciantes, aunque no fuesen de tanta capacidad, para el mismo intento; y aun separando de la idea aquel motivo, la memoria del Arca, en los tiempos y siglos siguientes al Diluvio, diéron á los hombres la primer idea de 
VIGSEIMOSEGUNDO.

de embarcaciones para navegar, capaces no solo de llevar personas, ó á lo ménos para mantenerse sobre las aguas sin sumergirse, sino tambien animales de todas especies. Con esta idea basta para discurrir, que aquellos primitivos tiempos fuese una de sus ocupaciones hacerlas al modo del Arca, y navegar por los rios y los mares, reconociendo si al igual de las tierras, que fuéron las primeras pobladas, habia otras, y exâminando lo que contenian: para esto no podian tener objeto mas adequado que la misma Arca, la qual ministraba toda la luz conveniente del modo de juntar los maderos, de la figura que debian darles para que se mantuviesen flotantes, $y$ de las comparticiones que convenia hacer: de este modo, sin apartarse de lo natural, y sirviéndose de las luces que les ministraba aquel portentoso suceso, es facilisima la poblacion de las Indias, excusando el recurso á los climas inhabitables de la Zona Frígida, ó de que el Occéano no lo hubiese sido ántes, sino tierra que se convirtiese en mar, despues de haber dado paso á los pobladores de aquella parte, y, sin que de lo mas Oriental y Septentrional del Asia fuesen á embarcarse para pasar á lo mas Septentrional y Occidental de las Américas. En las embarcaciones propuestas de aquellas primeras gentes pudiéron llevar cómodamente animales, fuese de propio intento ó por casualidad; así como despues de la entrada de los Españoles allá se han llevado las especies que no habia, y han multiplicado con la abundancia que se ve: en todo lo qual no hay cosa que repugne á la razon.

9. Mas regular es que en aquellos tiempos los hombres fabricasen embarcaciones grandes, y que navegasen, que el que dexasen de hacerlo entónces, y que lo practicasen muchos siglos despues; porque teniendo el exemplar mas presente, conocian lo que $\mathrm{Tt}$ pos 
podia aguantar una embarcacion, y que los mas fuertes embates de las olas del mar, agitadas, no eran suficientes para deshacerlas; sabiendo al mismo tiempo que podian unirse muchas piezas de madera de tal modo, que el agua no penetrase por sus junturas: y en fin, tenian presente el exemplar para seguirlo, mas bien que despues de corridos muchos siglos; y no obstante de estar la memoria mas remota, se fabricárón embarcaciones, se dispusiéron flotas numerosas, y se navegáron los mares, cuyo arresto ha sido ordinario en todos los tiempos, como lo testifican las noticias mas distantes.

Io De este modo fué facil poblarse las Indias en aquellos primeros siglos despues del Diluvio, no ménos que la muchedumbre de islas distantes de la Tierra Firme, de que están llenos los mares; muchas de las quales aun no están enteramente conocidas, como lo acreditan los descubrimientos que freqüentemente se hacen, particularmente en el Emisferio Austral.

I I El tránsito á las Indias desde las partes Orientales es regular, por ser los vientos favorables y bonancibles para ello en todo tiempo, pues qualquicra embarcacion que se dexe correr á su voluntad desde las costas de Europa en las partes Meridionales, ó de las de Africa, ha de ir por precision á dar á las Indias mas ó ménos apartadas de la Equinocial entre los Trópicos, sin necesitar de aguja, ni del conocimiento de las estrellas para dirigirse, porque los vientos son de la parte del Levante desde las islas de Canarias en adelante, que llaman Brisas; y ocupando las Américas toda la parte del Globo, desde las del Norte, á donde han podido llegar los descubrimientos, hasta los 55 grados en el Emisferio Austral, era preciso que la embarcacion que se dexase llevar de ellos fuese á dar á aquellas tierras. En los tiem- 
VIGESIMOSEGUNDO.

$33 I$ tiempos que el mundo empezaba á poblarse de nuevo, era regular que las gentes procurasen esparcirse tanto por tierra, pasando de region á region, como en naves, que imitasen, segun se ha dicho, la que habia conservado las especies de vivientes, dexándose conducir por los vientos y de las corrientes, asi como el Arca estubo á la voluntad de estos elementos, hasta que descansó en tierra; pues aunque esta iba gobernada de la mano de Dios, que lo tenia dispuesto, los hombres, inclinados á imitar lo que ven, tenian bastante con aquel exemplar, para no detenerse en poner por obra lo que les inclinaba la curiosidad, y el fin que les movia de ocupar toda la tierra para hacerse dueños de ella. Pasados aquellos tiempos en que se emprenderian estos viages, y visto por los contemporáneos que no volvia ninguno de los que iban en ellos, ni se tenia noticia de su paradero, es natural que les cntrase el temor de las resultas, y que no se determinasen á hacer nuevas tentativas: así como no hubiera habido resolucion para seguir los pasos de Colon, si no hubiese regresado del primer viage, ní se hubiese tenido noticia de haber llegado á descubrir tierras nuevas felizmente. Con esta desconfianza, no solo cesaria el empeño de arriesgarse, sino el motivo de hacer embarcaciones grandes, y así se iria perdiendo el método de fabricarlas, hasta que corriendo los tiempos volveria á renovarse, como sucedió por los Argonautas, en parte guiados de la disposicion de las embarcaciones pequeñas, en parte de algunas luces que no dexarian de conservarse de la antigüedad, y al mismo tiempo alentados del conocimiento de las estrellas, del curso de los astros, y de las luces de la Astrononía, que ya se tenian en la Grecia, y empezáron á navegar y establecer naves, capaces de surcar los mares con seTt2

gus 
guridad, y con conocimiento distinto del que podian tener las primeras gentes, para la direccion de sus viages.

I 2 Los que pasarian por el método que se ha dicho á las Indias, no podian volver de cllas por la misma razon que les era favorable para ir, teniendo los vientos contrarios: debiendo suponerse que entónces no poseian todo el conocimiento necesario para el mancjo de las velas, ni el correspondiente de la Náutica para hacer rumbos contrarios á donde el viento les impelia: por esto se hallarian precisados á permanecer en las primeras tierras que encontráron, abandonando enteramente la idea de restituirse algunos de ellos al parage donde habian salido; debiendo suponer, que al emprender el viage no presumirian, ni que estuviese tan distante, como despues experimentáron, la tierra, ni que les fuese imposible el regreso. Llegados allá recapacitarian sobre lo que habian tardado en llegar, y las cotrariedades que se ofrecian para la vuelta: todo lo qual les determinaba al partido de permanecer en las primeras tierras, que serian naturalmente las islas de Barlovento: irian pasando sucesivamente en embarcaciones chicas hasta la Tierra Firme, y en ella se constituirian nuevos pobladores, y dueños de una gran parte del mundo, manteniendo los usos y modales que lleváron de donde habian salido; unos se harian rústicos y feroces, otros mas dóciles y sociables: los primeros serian, como todavía se ve, los que habitaban en los paises montuosos de bosques, donde hay fieras $y$ animales dañosos en abundancia: los segundos los que se estableciéron en parages donde no hay bosques ni árboles, al modo que la parte baxa del Perú, en lo que llaman Valles, y en la alta, que tampoco se crian espesuras, ni la pueblan animales feroces. 
VIGESTMOSEGUNDO.

I3 La comunicacion despues de los que se estableciéron en las Indias con la Europa y el Africa, por la parte Oriental, era imposible, faltándoles el conocimiento de navegar por varios rumbos, el de la aguja magnética, ó en su lugar el de las estrellas, como tambien el de disponer las velas para que las naves hiciesen camino quando el viento no era favorable, porque no siendo practicable por entre los Trópicos, se hacia preciso buscar otro camino donde constantemente no fuese contrario como allí; y esto, para unas gentes que se habian dexado llevar por los vientos, no era asequible: así, puestos allá, quedáron aquellas tierras en la misma ignorancia que estaban ántes de haberse poblado para los que habitaban en las otras partes. Por la parte Occidental de la América, y las Orientales del Asia, las islas de los Ladrones y Filipinas, se ofrecen los mismos embarazos, necesitándose de tomar cierta altura para buscar los vientos ménos contrarios; y así por todos lados se hallaban atajados, reducidos á subsistir en donde se estableciéron, olvidando estos mismos con el tiempo que hubiese mas tierras que las que habitaban.

14 Los vientos desde la Equinocial, y aun algo mas al Norte, hasta quanto corre la América Meridional, en el mar del Sur, son constantes del Sur para el Norte en todo tiempo hasta la distancia de $8 \cap$ í roo leguas de las costas; y desde Mayo hasta Noviembre siguen igualmente en el espacio que hay desde la Equinocial hasta las costas de Panamá: desde Diciembre hasta Mayo son del Norte para el Sur en este último espacio, y suelen recalar así hasta los 3 grados Sur, que llaman Brisas. Lo mismo sucede en las demas costas que van dando la vuelta, y forman la América Septentrional, que unas veces corren del un lado, y otras del opuesto, pe- 
ro siempre segun ellos: por esto para hacer largas travesías es preciso forcegear con las embarcaciones muchas veces contra el viento, é ir á buscar los que son ménos contrarios á los parages donde reynan, siendo preciso para conseguirlo ciencia náutica, y conocimiento de los mares; de todo lo qual carecian aquellas gentes primeros pobladores, y por conseqüencia era imposible que saliesen de alli para ninguna parte, porque aunque lo intentasen los habian de voiver los vientos á las propias costas de donde habian salido, á ménos que por una providencia particular de Dios se mudase el órden de los vientos del curso regular que les dió; de modo, que siendo natural el que qualquiera embarcacion que se alargase un poco de las costas Meridionales y Occidentales de la Europa, ó de las Occidentales del Africa, vaya á dar á las islas de Barlovento, seria sobrenatural que las que estuviesen en estas, entregándose al impulso de los vientos, viniesen al Africa ó á la Europa; cuya circunstancia da motivo á admirar los secretos de la Providencia, que pudiendo haber detenido el Arca en las altas cordilleras de las Indias, que por ser las mas elevadas de la tierra son, como se ha dicho, las primeras que se descubriéron, no lo permitió así, porque en este caso era necesario obrar un segundo milagro, haciendo que el curso de los vientos, que va, segun el órden natural, de Oriente á Occidente en el ámbito de la Zona Tórrida, y mares grandes, y en lo restante del globo varía segun las estaciones, sin regular fixeza, mudase á la direccion opuesta de Occidente á Oriente, que era lo mismo que trastornar una parte de la naturaleza en aquel primer impulso que le dió su poder; y así le destinó el lugar para descansar en el vasto continente, que comprehende tres partes de las quatro del mundo; porque desde ellas era pre- 
VIGESIMOSEGUNDO.

cîso que se esparciesen las gentes y animales á la otra que se hallaba enteramente separada de ellas, sin sacar las cosas del órden natural.

I5 Christobal Colon fué al descubrimiento de las Indias por la noticia y los derrotaderos que tuvo antecedentemente, de donde supo que habia tierras por aquella parte, siendo en la isla de la Madera donde los consigió del piloto que en su casa estubo hospedado. Este habia sido arrojado allá por los vientos; y aunque con certeza no se sabe en qué forma hizo el viage, es natural que navegándose entónces de las Terceras á las costas de Portugal y de España, en alguno de los viages los vientos del Norte le cargasen mucho, y le llevasen á ménos latitud, donde los del Este son continuos; y puestos en la region de ellos lo fuesen llevando, sin tener arbitrio para volver á tomar el parage de donde habia salido, hasta que llegó á reconocer la primer tierra. Este exemplar, y el de Colon, que le siguió y sucedió en los siglos modernos, abren camino á la idea, para conocer que un acaso, sobrevenido en los tiempos que habia conocimiento de la Náutica, enseña lo que sucederia en los que se ignoraba; y que así como fuéron estos dos con embarcaciones pequeñas, irian en los primeros siglos con otras de la misma especie, ó mayores, aunque con ménos conocimierto de la Náutica, y ninguno del método de navegar por rumbos obliquos y extraviados á los mismos parages.

I6 La casualidad en mucha parte, por el curso de las corrientes, ayudada de la Astronomía y de las reglas de la Náutica, fuéron las maestras de estos dos célebres pilotos para discurrir el modo de regresarse á Europa, desembocando por los canales que forman las islas de Barlovento, y poniéndose en altura para buscar otros vientos distintos de los que les habian llevado, porque ya sabian que desde los 25 


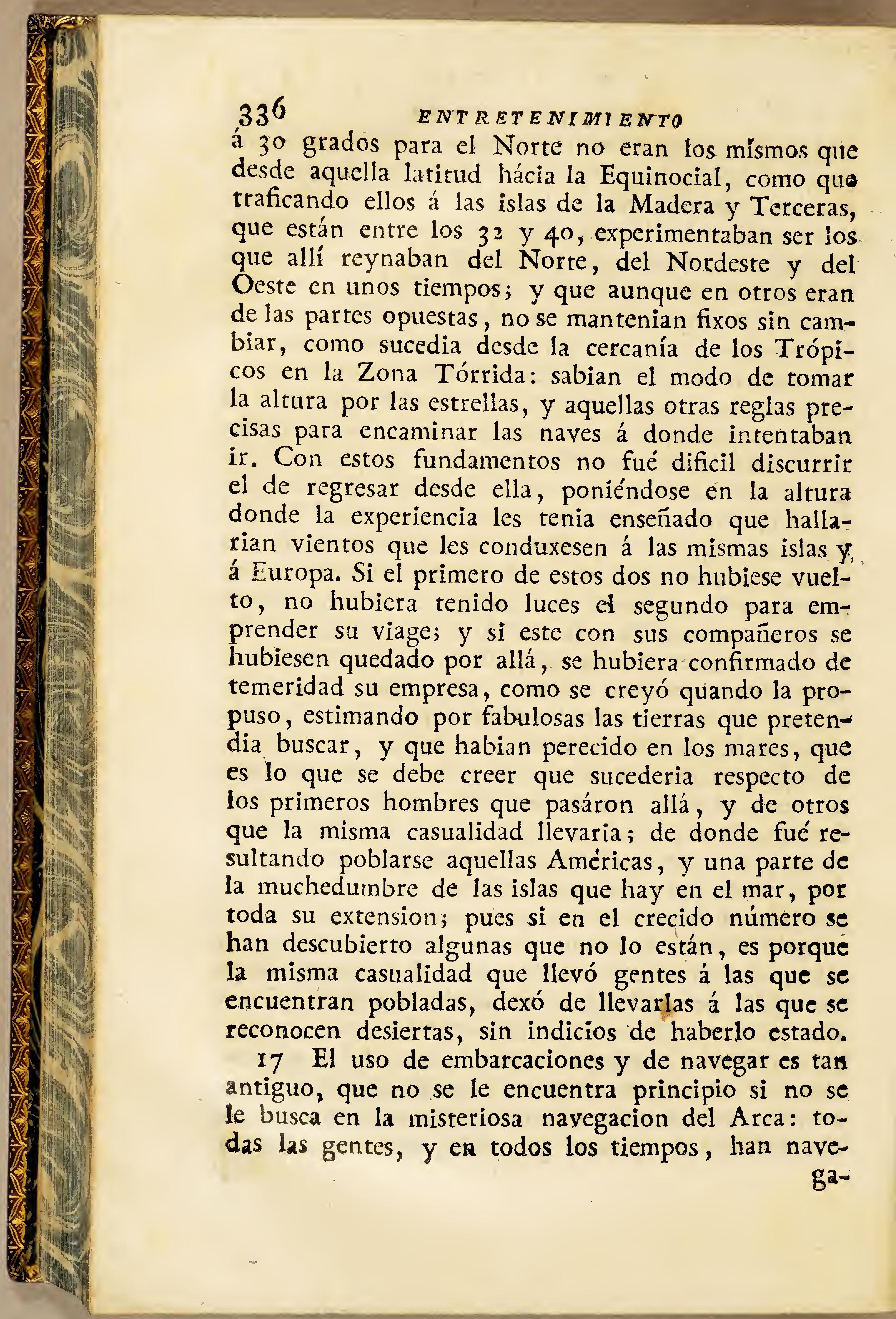


VIGESIMOSEGUNDO.

gado y han tenido embarcaciones: unos se sirven de ellas en los rios caudalosos y pequeños, para atravesarlos de una banda á otra, y para navegarlos como corren las corrientes, no ménos que haciéndoles oposicion, y subiendo contra ellos: otros las usan para surcar en los lagos, y pescar en ellos: otros en el mar, exponiéndose á salir buena distancia de sus costas; y por este término cada pueblo, segun los parages en que ha hecho su establecimiento, lo practica; pero generalmente se repara, que los Indios han preferido las orillas del agua en rios, lagos ó mares para establecerse, por la proporcion que les ofrecen de la pesca, que es uno de sus principales alimentos: siempre han usado embarcaciones de distintas figuras y tamaños: familiarizándose de tal modo con este elemento, que parecen anfivios, pues se exponen sin temor en canoas endebles, donde ninguna persona de reflexion lo hiciera: ellos no solo son nadadores desde pequeños, sino ágiles en el agua como pescados; hacen sus embarcaciones de troncos de árboles, unas mayores que otras, de cortezas de los mismos árboles, de hojas, de pellejos de lobos marinos, y de otras varias especies : con ellas se echan al mar, sin temor de las olas, ni desconfianza de la debilidad de la materia, y se alejan quanto quieren, sin que haya embates que se lo impidan. Sobre un solo palo redondo van á pescar, y guardan el equilibrio tan diestramente, que aunque el palo ruede, y aunque haga muchos tumbos, no caen, ni parece que trabajan con el cuerpo; siendo tan ágiles para pescar, como arrestados para salir a mar: si la embarcacion se les trastorna no se alteran, y desde el agua, nadando, vuelven á enderezarla, y se ponen dentro; observándose por regla general, que al paso que las gentes son mas bárbaras, incultas y feruces, son mas arrestadas, y mas $\mathrm{Vv}$ dies- 
$3.3^{8}$

diestras en el agua, familiarizándose mas con ella.

I 8 Las islas de Juan Fernandez, en el mar del Sur, distan roo leguas de la costa de Valparaiso, esto es, la que está mas inmediata; y los mares de este intermedio son recios y alterados, por ventar los Sures con fuerza, y ser esto continuo; de lo qual resulta, que los navios trabajan bastante en esta travesía. Por los años de 38 ó 39, hallándose en ellas un piloto de aquel mar, llamado Don Pedro Le Gu, que habia ido con el fin de hacer pesca, por ser entónces muy abundante de ella, tenia la gente de su embarcacion ocupada en este exercicio en canoas que habia llevado para el intento: á cada 3 ó 4 Indios daba una, y los repartia por la costa de la misma isla, á fín de que pasando el dia en ello, volviesen á la noche al puerto, que era donde se salaba y preparaba el pescado: en uno de los dias le faltó una canoa, y creyó que se hubiese pasado á la isla de Fuera, que dista 20 leguas de la de Tierra hácia el. Oeste ; pero viendo que no volvia al cabo de algunos dias, consintió en que se hubiese perdido : concluida su pesca fué con la embarcacion á Valparaiso, pero quedó bien sorprehendido al encontrarse allí con los Indios y la canoa, que sin mas motivo que el disgusto que tenian de hallarse en aquella is! a despoblada, resolviéron irse á la de Tierra-Firme, y únicamente con los canaletes para bogar: sin mas agua ni provisiones que las que habian sacado para el manteniniento del dia, se determináron á hacer el viage, arrostrando á los peligros, y sin embarazarse en los gruesos mares que no ignoraban debian experimentar en la travesía. De estos exemplarés hay muchos que pudieran citarse, con los quales se acredita la facilidad que tienen los Indios y las gentes mas bárbaras para hacer tales arrojos. 
VIGESIMOSEGUNDO.

I9 Del mismo modo que en estos tiempos se ve el modo que tienen los Indios y otras gentes bátbaras para hacer travesías en el mar, es regular que las hiciesen quando se poblaba el mundo; pues no se encuentra mas dificultad, ni tanto peligro en atravesar desde las islas de Canarias á las de Barlovento, que en hacerlo desde la de Tierra de Juan Fernandez á Valparaiso: el espacio que hay entre la del Ferro en Canarias, y la Martinica, es de 800 leguas, que á un navegar regular se pueden hacer en trece dias, y viene á ser al respecto de $2 \frac{x}{2}$ leguas por hora. Tambien puede hacerse en ménos tiempo, encontrando una coyuntura de brisas algo mas fuertes que lo regular. Esta travesía es tan natural, que los mares por lo comun están sosegados y serenos, sin alteracion; de tal modo, que los navios van andando mucho, y parece que no se mueven, siendo totalmente distinto de lo que sucede de la de Juan Fernandez á Valparaiso; y así en canoas puede practicarse con ménos riesgo de que se volteen, que aquella; originándose de esta tranquilidad el darles á aquellos mares el nombre de Golfo de las Damas. Supuesto esta serenidad, queda la dificultad reducida al modo de subsistir los que fuesen en las embarcaciones grandes ó pequeñas, que no habiéndose prevenido de víveres, y siendo casualidad el haber ido, es preciso suponer no llevaban los convenientes. Tambien debe advertirse, que las gentes bárbaras que no guardan régimen seguro en sus cosas, suelen pasarse dos y tres dias sin comer, sufriendo el hambre por costumbre, que sus naturalezas están hechas á ello, y á desquitarse despues quando tienen proporcion, practicándolo así aun estando en tierra: parece regular que un ayuno de ro ú I I dias seria en ellos lo mismo que en las que están arregladas, y en costumbre de comer varias $\mathrm{V} \mathrm{V}_{2}$

ve- 
veces en el dia, el de 4 ó $5, y$ esto se ha visto muchas veces en pérdidas de navios; pero ni aun era necesario tal ayuno, porque si los primeros pobladores emprendiéron el viage exprofeso para buscar tierras, y ocuparlas, era correspondiente que llevasen provision para algunos dias, que no se necesitaba hacerla muy grande, porque la gente que trabaja poco no es tan consumidora como la civilizada, que se emplea en exercicios recios, y necesita alimento á proporcion; pero si se quiere que fuese la casualidad quien los arrojó allá, es regular que acaeciese quando salian á pescar, que es el único objeto que entónces, como ahora, los llevaba al mar, y con poco pescado que hubiesen cogido les bastaba para mantenerse algunos dias. Ademas de esto, en aquellos mares hay abundancia de voladores, que en partidas ó bandadas grandes vuelan bastante trecho, huyendo de los dorados, taburones, y otros pescados que les persiguen, y en el vuelo no dexan de caer algunos dentro de las embarcaciones: hay tambien de estos otros, y con poca porcion que tomasen tenian suficiente para alimentarse ínterin que llegaban á tierra; con que de qualquier modo no habia dificultad en que fuesen, y se hallasen en aquellas islas primeras, donde se repondrian de los ayunos de la navegacion.

20 Los Indios, aun en los tiempos presentes, sin embargo de estar civilizados, acostumbran comer el pescado crudo y vivo, quando está saltando en las playas, acabado de sacar con las redes, siendo esto tan comun en ellos, que hacen su comida al mismo tiempo que pescan. Esta costumbre la conservan sin duda de lo antiguo, debiendo inferir de ello serles mas facil el sustentarse en qualquier accidente, que á las personas que necesitan condimentarlo al fuego; y de aquella forma les sustenta mas, 
y les altera ménos, necesitando ménos de beber que quando el alimento está preparado con sal, con co. sas grasas, ó con otros ingredientes que se le añaden para avivar el gusto.

2 I Si se quiere que en aquellos tiempos las gentes no se alimentasen de cosa que tuviese vida, y que lo hiciesen de yerbas, de raices y de frutas, es necesario que los pobladores salieran de intento á buscar la tierra, porque no tenian otro motivo que les moviese á salir al mar, faltándoles el de solicitar el pescado para alimentarse; y entónces era preciso que embarcasen los víveres convenientes para determinado número de dias, sin que embarace la mayor duracion del viage, respecto de los que llevaban: tal vez sucederia que la necesidad les enseñase á comer el pescado, que hasta entónces no lo tenian en uso. Otra razon hay que corrobora la idea de que la poblacion se hiciese transfiriéndose por mar, y no por tierra; $y$ es el que para que se poblasen las Islas Terceras, que distan de la Europa 300 leguas, las de Cabo Verde Ioo, y otras varias, fué preciso que los pobladores se trasportasen por mar, porque absolutamente no habia medio para discurrir que lo hicicsen de otro modo; y esto acredita que en aquellos tiempos era general el empronder los viages de esta especie, logrando unos encontrar las tierras mas breve que orros. Las dos Américas en total, por lo que hasta el presente se sabe, son islas; y quando esto no sea, y que tenga union por el Norte con la Europa ó con el Asia, será por parages tan remotos, que son intratables, y no comunicables por el mucho frio y nicves, siendo un clima helado, que no corisicnte quasi animal; y asi por todas razones parece no dexar duda que los primeros vivientes fuéron conducidos por el agua, que es lo mas natural, mayormente si se sigue el órden de la semejanza: pues 


\section{2}

ENTRETENIMIENTO

habiendo Dios elegido para conservar las especies el medio del Arca, que era una grande nave, y que entregada á la voluntad de las aguas y de los vientos se mantuviese sin detrimento hasta que se retiraron aquellas, parece regular que por el mismo medio volviesen á poblarse las tierras que habian quedado sin habitantes, y estaban separadas de las otras, inspirándolo así á las gentes para que lo pusiesen en planta, y dándoles por norma la misma Arca donde se conserváron tan prodigiosamente las criaturas y animales, cuyo portento fué, á imitacion del de la Creacion, la obra de la Omnipotencia, y una de las maravillosas señales que dexó en el mundo de la Sabiduría infinita, y de sus incomprehensibles providencias, con las quales reparó piadoso lo que el brazo de su Justicia habia exterminado. 





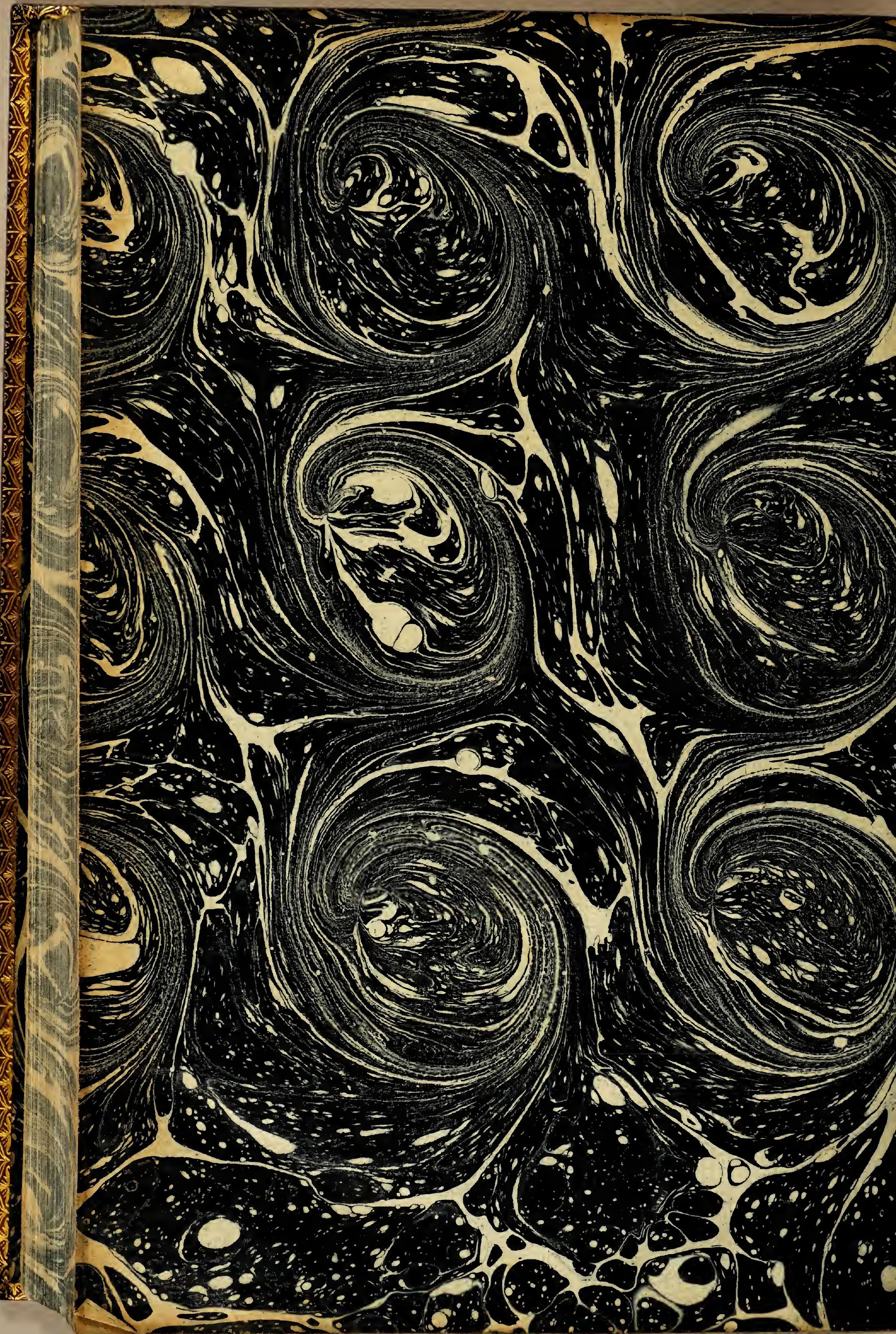




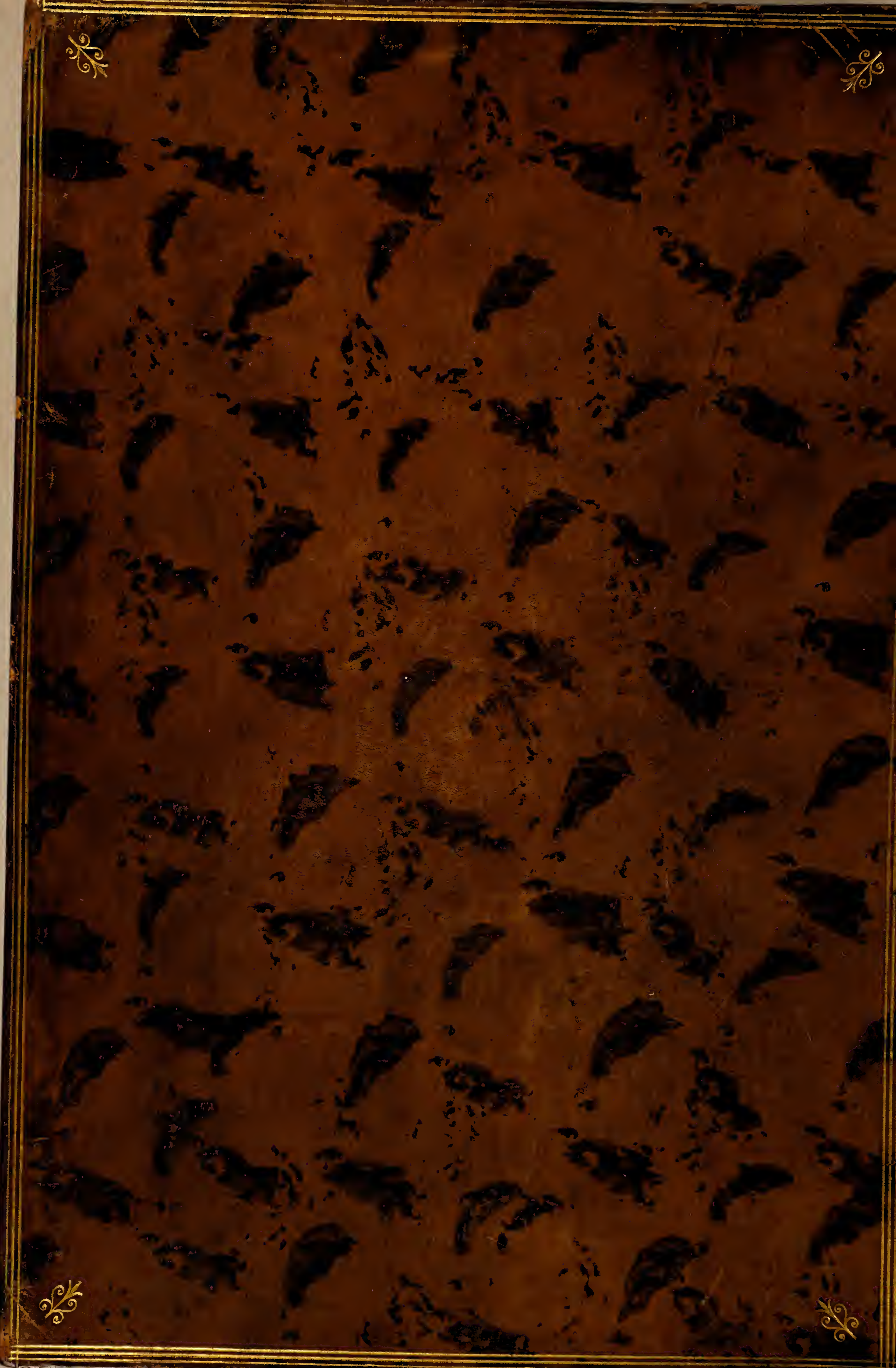

